九州大学学術情報リポジトリ

Kyushu University Institutional Repository

On the bionomics of Lyctocoris beneficus (Hiura) and Xylocoris galactinus (Fieber) (Anthocoridae, Heteroptera)

Chu, Yau-i

Entomological Laboratory, Department of Agriculture, Kyushu University

https://doi.org/10.5109/22783

出版情報: 九州大学大学院農学研究院紀要. 15 (1)，pp.1-136，1969-03. Kyushu University バージョン：

権利関係 : 
Journal of the Faculty of Agriculture, Kyushu University, Vol. 15, No. 1 March 25, 1969

\title{
On the bionomics of Lyctocoris beneficus (Hiura) and Xylocoris galactinus (Fieber) (Anthocoridae, Heteroptera) *
}

\author{
Yau-i $\mathrm{CHU}_{\mathrm{HU}}$
}

\section{Contents}

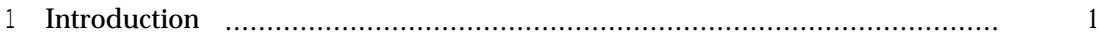

2 Historical review .............................................................................. 2

3 Economic importance of Anthocorid bugs as natural enemies .................. 3

4 Systematics and descriptions ................................................................ 6

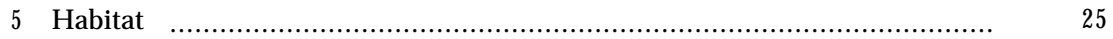

6 Laboratory observation on the life history ............................................ 26

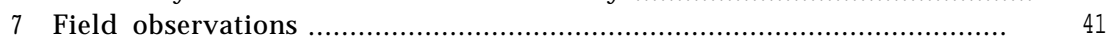

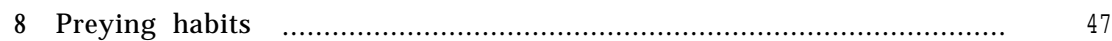

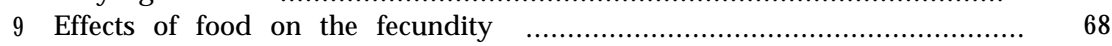

10 Rearing with artificial media .......................................................... 75

11 Ovarian development under certain nutritional conditions ........................ 83

12 Effect of population density on the survival, growth and fecundity ......... 87

13 Overwintering and cold-hardiness .................................................... 92

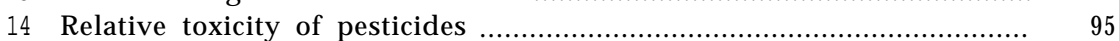

15 Inter-specific competition between L. beneficus and X. galactinus ............ 104

16 Co-existence with Apanteles chilonis [Munakata] ................................. 108

17 Approach to the mass production ................................................. 110

18 Attack of bugs to man .................................................................... 113

19 Conclusion-Evaluation of bugs as predators against the rice stem borer... 114

20 Summary ................................................................................ 119

21 Acknowledgement ......................................................................... 123

22 Literature cited .......................................................................

\section{Introduction}

In certain rice growing countries, the rice stem borer (Chilo suppressalis (Walker)) is causing serious damage to rice, and to combat the borer, an extensive use of insecticides is necessary to obtain a standard yield. On the other hand, the feasibility of biological control of the borers has been recently re-emphasized, and voluminous papers have been published in these

* Contribution Ser. 2, No. 288, Entomological Laboratory, Kyushu University. Special Project Research supported by the Ministry of Education "Studies on the Dynamic Status of Biosphere." This study was carried out as part of JIBP. 
several years. The list of natural enemies of rice stem borers was compiled by Nickel (1964), Rao and Chawla (1964), Yasumatsu (1967), Yasumatsu and Torii (1968) and others. Yasumatsu recorded 79 species of parasites and 20 species of insect predators from Asian area. Up to the present, many prominent works have been conducted on some parasitic insects, while little is known on the predatory natural enemies of the borers, although they also contain very effective members. For example, the Anthocorid bug, Lyctocoris beneficus (Hiura), sometimes occurs abundantly in the straw piles and barns, attacking overwintering larvae and the newly emerged adult moths of rice stem borer in the spring. According to Oho's investigation, during the spring of 1953, more than 90 percent newly emerged adults of the rice stem borer were attacked by this bug in the straws in Kyushu, Japan (Oho 1955a, b). The importance of this bug as a controlling agent against the overwintering rice stem borer during the colder season was also emphasized by some workers (Kobayashi 1958, Bess 1967, Yasumatsu 1967, etc.). Although some fragmental informations on this Anthocorid predator have been recorded by some workers, it seems extremely necessary to make a detailed study of this bug before the practical trial of this Anthocorid as a biological control agent against the rice stem borer. The purpose of the present work is to get fundamental informations to evaluate the availability of $\boldsymbol{L}$. beneficus and Xylocoris galactinus (Fieber), another Anthocorid, which is often more predominantly found than L. beneficus in the similar environment, as natural enemies against the rice stem borer.

\section{Historical review}

Lyctocoris beneficus (Hiura) was at first described by Hiura (1957) as a new species of Euspudaeus, but the history of the finding of this species goes back to 1953. In this year great numbers of this bug were discovered in the giant straw piles at Saga Paper Board Co. in Kyushu, Japan, and they were considered to be an effective predator in checking the emergence of rice stem borer moths in late spring. On the other hand, the high mortality of this bug against BHC was reported (Anonym 1953). In the next year, the susceptibility of this bug against several insecticides was tested in Saga Agricultural Experimental Station, and at the same time some brief biological notes were recorded (Anonym 1954). Oho (1955a) made a preliminary report of this bug under the name of Euspudaeus sp. and recorded fragmental ecological notes as well as a highly susceptibility against BHC. This same preliminary report was also published in another magazine (Oho 1955b). In the same year, he published the feeding habit and life history of this bug as the first report of the study of this bug (Oho 1955c), and some illustrations relating to this bug were also published (Mizukami and Oho 1955). In 1957, Hiura described the adult as a new species of Euspudaeus, and gave th description of each stage of the nymphs of this bug together 
with its biological data. His materials were collected from 31 localities which were covering the entire Japan except Hokkaido. The anatomical studies on the ovariole and alimental canal of this bug as well as Xylocoris galactinus (Fieber) were conducted by Miyamoto (1957, 1961). The generic name of this bug was later revised to Lyctocoris by I-Iiura (1966). The distribution of this bug is now confined to Japan and Quelpart Island in Korea (Miyamoto and Lee 1966).

On the contrary, Xylocoris galactinus (Fieber) was discovered more than 130 years ago. At first, Fieber (1836) described the species under the name of Anthocoris galactinus. Since then, it has long been known as Piezostethus galactinus (Fieber). Its taxonomical, morphological and biological studies as well as collecting data have been accumulated by many workers (Reuter 1884, Poppius 1909, Butler 1923, Blatchley 1926, Carayon 1953, Southwood and Leston 1959, Hiura 1966, etc.). Contrary to the long year studies of this species, the nymphal morphology was first described by Hall (1951), and he also studied its ecology in the grain stock yard. The biology under the same environment was later discussed by Sinha (1961). Thus, the bug is known as a cosmopolitan species and recorded from Europe, North and South America, Asia, North Africa and Micronesia etc., and Herring (1966) attributed its wide distribution to the transportation of bug-infested food-stuff.

\section{Economic importance of Anthocorid bugs as natural enemies}

Both Lyctocoris beneficus (Hiura) and Xylocoris galactinus (Fieber) belong to the family Anthocoridae, which include numerous small and inconspicuous species living in flower and other more or less hidden situations, and cornmonly known as the name of "flower bug" or "minute pirate bug." A number of Anthocorid bugs were recorded as the predators of plant mites, Lepidopterous larvae and eggs, thrips, leafhoppers, psyllids, scale insects, whiteflies and similar small or soft sclerotized insects. However, their predatory behaviour had been almost overlooked because of their small size and inconspicuous habit. The importance of these bugs as the biological control agents has been pointed out by some workers (Massee and Steer 1926, Ishihara 1941, Carayon 1961, etc.). For example, Orius insidiosus (Say) which preys on more than 40 species of insects and mites was recognized as an important predator of Tetranychus bimaculatus Harvey (McGregor 1913), T. pacificus McGregor (Michelbacher et al. 1952), Paratetranychus pilosus C.-F. (Garman and Jewett 1938, Lord 1949, Johansen and Brekey 1949),Taeniothrips gladioli M.-S. (Richardson 1933), Blissus leucopterus (Say) (Flint 1918), Thrips tabaci Lindeman (Ogilvie 1927), Heliothis obsoleta (Fabricius) (Phillips and Barber 1933, Barber 1936a, b, Hanison 1960), H.zea (Boddic) (Bell and Whitecomb 1964), Psallus seriatus Reuter and Alabama argillacea Hiibner (McGregor 
1942). In addition to these, some experimental works on the biological control of insect pests or mites using Anthocorid bugs, such as Paratriphleps laeviusculus (Champion), 0 rius insidiusus (Say), 0. tristicolar (White), Montandoniola moraguesi Puton, Tetraphleps sp. etc. have been undertaken by several American entomologists (Annand1942a, b, Weber 1953, Sweetman 1958, Davis and Krause 1963, 1964, 1965a, b, Funasaki 1966, Mitchell and Wright 1967).

In Japan, the studies on the Anthocorid bugs as the natural enemies were rather few and all the records on the bugs with exact specific names were compiled by Yasumatsu and Watanabe (1964). Besides, Ito et al. (1960) and Oku and Kobayashi (1966) reported the predation of O rius spp. on Pieris rapae crucivora Boisduval and some species of aphids in soybean field respectively.

Before giving the author's observation on the predation of L. beneficus and $\mathrm{X}$. galactinus, the author gives the world records of data which have been observed by many authors on the Lepidopterous hosts preyed by various species of Anthocorids. As mentioned previously, Lepidopterous larvae are actually the most favourable hosts of the Anthocorid bugs, and sometimes their eggs become more attractive food for the bugs. The oldest preying data was introduced by Douglas and Scott (1865) who reported the preying of Anthocoris nemoralis (Fabricius) and A.nemorum (Linné) on the Lithocolletis spp. (Lithocolletidae). Since then, 11 species of predators and 19 species of prey have been recorded by several workers.

Although Lyctocoris campestris (Fabricius) and Xylocoris crusitans (Fallen) were described far back to 1794 and 1807 respectively, studies on their preying habits have been neglected. The first preying record of Lyctocoris bug was made by Corti (1921) who observed the attack of L. campestris on the silkworm larvae as well as prepupa through the wall of its cocoon, but later Malenotti (1925) opposed Corti's observation and wrote that the bug does not prey upon the prepupa through its cocoon. Two other preying records of $\mathbf{L}$. campestris were made on the potato tuber moth (Phthorimaea terrella Zeller) and Tussock moth (Hemerocampa vetusta Boisduval) as given in Table 1. The association of $\mathbf{L}$. campestris with stored products was reported by Howe (1952) who also indicated the predation of this bug on Khapra beetle (Trogoderma granarium Evert). The preying of another Lyctocoris bug was observed by Fronk (1947). He observed that L. elongatus (Reuter) was feeding on the pine beetle Dendroctonus frontalis Zimmerman.

The first preying data of Xylocoris bug was recorded by Trägardh (1914) who found $\mathrm{X}$. crusitans in the burrows of bark beetles and confirmed the predation of the bugs on their larvae. The preying data on another bark beetle, Ips typographus Linné, was reported by another worker (Mokrzecki 1923). The attack on Tribolium confusum Duval by X. crusitans was observed by Good (1936). Nutting and Gerhardt (1964) found that X. flavipes (Reuter) was abundant in grain storage which was heavily infested by Khapra beetle, 
Table 1. Preying record of Anthocorid bugs on Lepidopterous insects (Arranged in chronological order).

\begin{tabular}{|c|c|c|c|}
\hline Predator & Host & Locality & Reference \\
\hline Orius insidiosus & Heliothis obsoleta & U.S.A. & Garman et al. 1914 \\
\hline Orius sp. & Spilonota ocellana & U.S.A. & Wilson et al. 1915 \\
\hline Orius sp. & Pectinophora gossypiella & Egypt & Willcocks 1916 \\
\hline Orius sp. & Spilonota ocellana & Canada & Duport 1917 \\
\hline Lyctocoris campestris & Bombix mori & Italy & Corti 1921 \\
\hline Orius tantilus & Pectinophora gossypiella & India & Ballard 1921 \\
\hline Orius insidiosus & Heliothis obsoleta & U.S.A. & Phillip et al. 1923 \\
\hline Orius australis & Heliothis obsoleta & Australia & China 1926 \\
\hline Lyctocoris campestris & Phthorimaea terrella & U.S.A. & Underhill 1926 \\
\hline Orius australis & Heliothis obsoleta & Australia & Veitch 1927 \\
\hline Orius insidiosus & Laphygma frugiperda & U.S.A. & Luginbill 1928 \\
\hline Orius insidiosus & Heliothis obsoleta & U.S.A. & Winburn et al. 1932 \\
\hline Orius sp. & Heliothis 'obsoleta & S. Africa & Parsons et al. 1934 \\
\hline Orius insidiosus & Heliothis obsoleta & U.S.A. & Barber 1936a, b. \\
\hline Anthocoris musculus & Eulia mariana & Canada & Gilliatt 1937 \\
\hline Orius sauteri & Ostrinia nubilalis & Japan & Koo 1940 \\
\hline Scoloposcelis parallelus & Scirpophaga nivella & Java & Diakonoff 1940 \\
\hline " & Scirpophaga auriflua & " & " \\
\hline " & Proceras venosatus & " & " \\
\hline " & Chilotraea auricilia & " & " \\
\hline " & Ostrinia nubilalis & " & \\
\hline Orius insidiosus & Heliothis obsoleta & U.S.A. & Marcovitch et al \\
\hline Orius insidiosus & Heliothis obsoleta & U.S.A. & Annand $1942 a^{1941}$ \\
\hline Paratriphleps laeviusculu. & s Heliothis obsoleta & U.SA. & Annand 1942b \\
\hline Orius sp. & Heliothis virescens & Peru & Anonym 1942 \\
\hline Orius insidiosus & Heliothis obsoleta & U.S.A. & Fletcher et al. 1943 \\
\hline Orius insidiosus & Heliothis obsoleta & U.S.A. & Ewing et al. 1943 \\
\hline Orius insidiosus & Heliothis obsoleta & U.S.A. & Barber 1943 \\
\hline Paratriphleps laeviusculu. & s Heliothis virescens & Peru & Hambleton 1944 \\
\hline Orius albidipennis & Prodenia litura & Egypt & Kamel 1951 \\
\hline Paratriphleps laeviusculus & s Heliothis virescens & Peru & Wille 1951 \\
\hline Orius tristicolar & " & " & " \\
\hline Paratriphleps laeviusculus & s Heliothis virescens & Peru & Simon 1954 \\
\hline Orius tristicolar & " & " & " \\
\hline Orius insidiosus & Ostrinia nubilalis & U.S.A. & Bartholomai 1954 \\
\hline Anthocoris musculus & Spilonota ocellana & Canada & Stultz 1955 \\
\hline Orius tristicolar & Platynota stultana & U.S.A. & Atkins et al. 1957 \\
\hline Lyctocoris campestris & Hemerocampa vetusta & U.S.A. & Atkins 1958 \\
\hline
\end{tabular}


Predator

0 rius sp.

0 rius sp.

O rius insidiosus

0 rius sp.

0 rius $\mathrm{sp}$.

0 rius insidiosus
Host

Locality

Reference

\begin{tabular}{|c|c|c|}
\hline Prodenia sp. & Egypt & Hassan et al. 1960 \\
\hline Pieris rapae crucivora & Japan & Ito et al.. 1960 \\
\hline Heliothis obsoleta & U.S.A. & Hanison 1960 \\
\hline Bucculatrix thurberialla & U.S.A. & Tuttle et al. 1961 \\
\hline Heliothis zea & U.S.A. & Wene et al. 1962 \\
\hline Heliothis zea & U.S.A. & Bell et al. 1964 \\
\hline
\end{tabular}

though its feeding habit was not observed. But they listed the bug as its predator. The beneficience of $X$. flavipes and L. campestris was postulated by Bosvine (1951) writing as follow : "Those bugs may be encountered in food stores, especially large ones such as warehouse and granaries. - they are quite harmless to man and even beneficial, since they live sucking the juice of the beetles and moths or sometimes of mites." A Tingid bug, Gargaphia bimaculata Parshley added to a prey list of Xylocoris bug by Bondar (1924). Besides, some predatory observations of X. galactinus were recorded by Hall (1951).

\section{Systematics and description}

The family Anthocoridae occurs in almost all parts of the world and includes more than 400 described species. The character of this family was summarized by Blatchley (1926) as follows : "very small oval or oblongoval sub-depressed bugs having the head long, porrect, inserted in thorax to or almost to eyes; tylus stout, prominent, protruding between and in front of bases of antennae, its apex blunt ; ocelli present ; bucculae wanting ; beak 3-segmented, its apex acuminate, the first segment usually shorter than head ; antennae 4-segmented ; pronotum short, more or less trapezoidal ; scutellum small, triangular ; mesonotum in part or wholly visible ; elytra usually present, covering the abdomen and with a distinct cuneus and embolium, membrane without closed cells, its veins few or wanting ; legs short, subequal in length, the front ones not raptorial, tarsi 3-segmented; metasternum with a more or less distinct, osteolar channel connecting with the scent glands. Males with a single asymmetrical genital plate ; genitals of female with a narrow medial sheath flanked on each with two larger triangular plates."

The family was divided into three subfamilies by Blatchley (1926) and China and Miller (1955, 1959).

\section{Family Anthocoridae (Amyot \& Serville)}

Amyot \& Serville, 1843. Hist. Nat. Hemipt., pp. 37, 262 (Anthocorides).

Fieber, 1851. Genera Hydroc., p. 9 (Anthocoridae). 


\section{Subfamily Lyctocorinae (Reuter)}

Reuter, 1884. Monog. Anthoc., p. 4. Div. Lyctocorina.

Champion, 1900. Biol. Centr. Am., Heter., 2: 306. Div. Lyctocoraria.

Oshanin, 1909. Verz. palae. Hemip., 1 : 613. Div. Lyctocoraria.

Oshanin, 1912. Kat. palae. Hemip., p. 58. Tribe Lyctocoraria.

Van Duzee, 1917. Cat. Hemip. Am. N. Mexico, p. 288. Subfam. Lyctocorinae.

\section{Subfamily Anthocorinae (Reuter)}

Reuter, 1884. Monog. Anthoc., p. 4. Div. Anthocoraria.

Champion, 1900. Biol. Centr. Am., Heter., 2: 319. Div. Anthocoraria.

Oshanin, 1909. Verz. palae. Hemip., 1: 613. Div. Anthocoraria.

Oshanin, 1912. Kat. palae. Hemip., p. 56. Tribe Anthocoraria.

Van Duzee, 1917. Cat. Hemip. Am. N. Mexico, p. 292. Subfam. Anthocorinae.

\section{Subfamily Dufouriellinae Van Duzee}

Reuter, 1884. Monog. Anthoc., p. 4. Div. Xylocoraria.

Champion, 1900. Biol. Centr. Am., Heter., 2: 330. Div. Xylocoraria.

Oshanin, 1909. Verz. palae. Hemip., 1: 633. Div. Xylocoraria.

Van Duzee, 1916. Check list Hemip., p. 35. Subfam. Dufouriellinae.

Van Duzee, 1917. Cat. Hemp. Am. N. Mexico, p. 295. Subfam. Dufouriellinae.

These subfamilies are easily distinguished by the following key (China and Miller 1959).

la Basal margin of pronotum not deeply emarginate ; scutellum not transversely sulcate ; cell of the hind wings with a hamus.............. 2

b Basal margin of pronotum deeply emarginate; scutellum transversely sulcate ; cell of the hind wings without a hamus.

Subfamily Duf ouriellinae

2a Third and fourth segments of antennae slender, linear and beset with numerous long hairs ; hamus with a connecting vein; front femora usually more or less swollen. ....................... Subfamily Lyctocorinae

b Third and fourth segments of antennae short, fusiform, with hairs very short; hamus without a connecting vein and run from subtended or decurrent vein; frontal femora never swollen.

Subfamily Anthocorinae

Subfamily Lyctocorinae was firstly established by Reuter (1884) by the name of Division Lyctocoraria and this name was later adopted by some authors and finally changed to the present name by Van Duzee and Edward (1916). The species of this subfamily have the third and fourth antenna1 segments much more slender than the preceding segments, and longer than the diameter of the segments. The hairs on the third and fourth antenna1 segments are long and remarkable. In hind-wings, hamus runs from the connecting vein, except in the case of the genus Plochiocoris. The subfamily includes 14 genera and they are: 


\section{Asthenidea Reuter}

Reuter, 1884. Monog. Anthoc. p. 602.

2. Eulasiocolpus Champion

Champion, 1900. Biol. Centr. Am., Heter., 2 : 313.

3. Euspudaeus Reuter

Reuter, 1884. Monog. Anthoc., p. 565.

4. Iella Carayon

Carayon, 1958. Memo. Inst. Sci. Madag., (E) 9 : 335.

5. Lasiochiloides Champion

Champion, 1900. Biol. Centr. Am., Heter., 2 : 311.

6. Lasiochilus Reuter

Reuter, 1871. Öf. Vet. Aka. Förh., 28: 562.

7. Lasiocolpoides Champion

Champion, 1900. Biol. Centr. Am., Heter., 2 : 313.

8. Lasiocolpus Reuter

Reuter, 1884. Monog. Anthoc., p. 581.

9. Lepidophorella Poppius

Poppius, 1909. Acta Soc. Sci. Fenni., 37 (9) : 43.

10. Lilia White

White, 1879. Ent. mon. Mag., 16 : 147.

11. Lyctocoris Hahn

Hahn, 1835. Wanz. Ins., 3 : 19.

12. Oplobates Reut er

Reuter, 1895. Ent. mon. Mag., 31 : 171.

13. Plochiocoris Champion

Champion, 1900. Biol. Centr. Am., Heter., 2 : 311.

14. Xylocoris Duf our

Dufour, 1831. Ann. Sci. Nat. Paris, 22: 423.

These genera may be distinguished by the following key:

Ia Wings without hamus in the cell.

.P.lochiocoris Champion

b Wings with hamus in the cell

$2 a$ Sides of pronotum marginate and explanate, not setose: fore femora with a tooth beneath at about distal one-fourth. Lilia White

b Sides of pronotum not or narrowly or incompletely explanate, always distinctly setose, fore femora not so armed.

3a Head about twice as long in front of eyes as length of an eye. . . . . . . . . . . . . . 4

b Head measured from above, not conspicuously longer in front of eye than length of

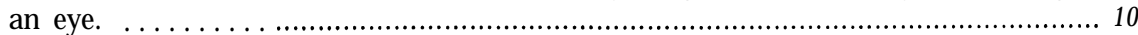

4a Osteolar channel on metapleuron short or long, forwardly curved. . . . . . ............. 5

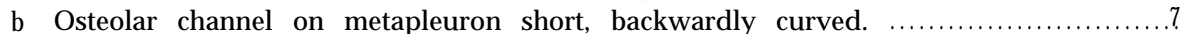

5a Osteolar channel short. ........................................... Lasiocolpoides Champion 
b Osteolar channel long.

6a Membrane of hemielytra with a single distinct vein, abdominal apex with several long bristle-like hairs. ...................................... Lasiochiloides Champion

b Membrane of hemielytra with 4 distinct veins, abdominal apex ciliate.

7a Sides of hemielytra serrately emarginate, rostrum reaching to metacoxae.

Oplobates Reuter

Lasiocolpus Reuter

b Sides of hemielytra not emarginate, rostrum extending to mesocoxae. ........... 8

8a Notum covered with yellowish normal hairs. .................... Lasiochilus Reuter

b Notum covered with scale-like hairs. ........................................... 9

9a Hairs on hemielytra composing tufts............................... Iella Carayon

b Hairs on hemielytra not composing tufts. ................... Lepidophorella Poppius

10a Osteolar channel curved forward or backward, with a rounded angle. ........... 11

b Osteolar channel nearly straight, joining at a sharp right angle. ................. 13

11a Frontal femora more or less swollen, clavus impunctate. .......... Xylocoris Dufour

b Frontal femora long and slender, clavus with two or three rows of punctures. ... 12

12a Eyes very large and oval, without a neck, sides of pronotum strongly sinuate.

Eulasiocolpus Champion

b Eyes not large, witha stout and cylindrical neck behind eyes, sides of pronotum

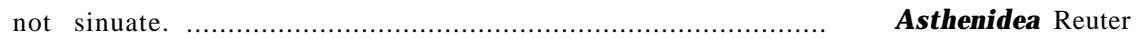

13a Sides of pronotum distinctly marginate, the apical angles wide and dull, not flattened, hemielytra with or without luster, thickly punctate. ........ Lyctocoris Hahn

b Sides of pronotum sinuate and not marginate, the apical angles flattened, hemielytra shining, coarsely punctate.

Euspudaeus Reuter

The genus Lyctocoris Hahn was erected to contain a single species, domesticus (Hahn 1835). Subsequently, Reuter (1871a) placed domesticus as a synonym of Acanthia campestris Fabricius. Reuter (1871b) erected the genus Dolichomerus with two included species, but later considered it as a synonym of Lyctocoris Hahn (Reuter 1884) and the genus remains taxonomically stable to the present.

\section{Genus Lyctocoris Hahn}

\section{Haplotype, domesticus Hahn= campestris (Fabr.)}

Hahn, 1835. Wanz. Ins., 3: 19.

Fieber, 1869. Wien Ent. Monat., 3: 264.

Flor, 1860. Rhyn. Livl., 1 : 665 (Subgenus of Xylocoris).

Fieber, 1861. Europ. Hemip., p. 38.

Douglas \& Scott, 1865. Brit. Hemip., p. 498.

Reuter, 1871. Öf. Vet. Aka. Förh., 27 : 409 (Dolichomerus).

Reuter, 1884. Monog. Anthoc., p. 560.

Champion, 1900. Biol. Centr. Am., Heter., 2: 309.

Provancher, 1886. Pet. Fauna Ent. Can., 3: 90 (Tetraphleps).

(Haplotype $=$ canadensis Prov.).

Van Duzee, 1917. Cat. Hemip. Am. N. Mexico, p. 288.

Blatchley, 1926. Heter. E-N. Am., p. 623.

Zimmerman, 1948. Ins. Hawaii 3: 174.

Kelton, 1962. Can. Ent. 94 : 1302. 
Kelton, 1967. Can. Ent. 99 : 807,

This genus may be known by the following characters:

Body oblong or oblong-oval, usually subopaque almost glabrous species having the head across as wide as long, narrower than the front of pronotum, eyes large, placed close to the base of head. Ocelli situated near the inner margins of the eyes. Tylus stout, its apex truncate. Antennae: 1st and 2nd segments thick, 1st cylindrical, reaching to the end of the face ; 2nd gradually clavate, about $21 / 2$ times as long as $1 s t$; $3 r d$ and 4th thin, filiform, subequal in length, with prominent bristles. Rostrum long, reaching to the apex of the metasternum; 1st segment scarcely so long as the head, 2nd 1\%3 times as long as the 1st. Pronotum subtrapezoidal, with its anterior margin sinuate, wider than the head across the eyes; anterior angles depressed, rounded; side margins thick, raised, with a slight linear impression within; posterior margin concave. Scutellum large, impressed at the middle. Hemielytra long oval, reaching apex of abdomen, clavus concave; claval suture depressed, corium flat; anterior margin reflexed; cuneus deflected; membrane with 1 vein at the corner of the cell. Mesosternum short, very slightly convex, posteriorly with a broad flat depression. Metasternum right angled, base convex, end depressed. Legs all alike, slender, while front coxae short, subcontiguous; front femora elongate, fusiform, but slightly swollen, unarmed. Osteolar channel nearly straight jointing at a sharp right angle a very fine carina which is extending to the front margin of metasternal plate. Males with a short spongy fossa at the apex. According to Kelton (1967), this genus is easily distinguished from the other Anthocoridae by the shape of 5 following points : 1) the osteolar channel, 2) 3rd and 4th antennal segments, 3) anterolateral margins of the pronotum, 4) male genitalia and 5) female abdominal segments.

This genus includes 24 species, 5 from Palaearctic, 8 from Nearctic, 6 from Ethiopian, 6 from Neotropical, 2 from Oriental and Australasian Regions. Among them one species is world-wide in distribution.

\section{Lyctocoris albifer Walker}

Lyctocoris albifer Walker, 1872. Cat. Heter. Brit. Mus. 5: 154.

Madeira.

\section{Lyctocoris beneficus (Hiura)}

Euspudaeus beneficus Hiura, 1957. Sci. Bull. Fac. Agr. Kyushu Univ. 16 (1): 31.

Lyctocoris beneficus Hiura, 1966. Bull. Osaka Mus. Nat. Hist. 19 : 33.

Japan, Korea.

3. Lyctocoris campestris (Fabricius)

Acanthia campestris Fabricius, 1794. Ent. Syst. 4: 75.

Salda campestris Fabricius, 1803. Syst. Rhyn. p. 116.

Anthocoris campestris : Stål, 1868. Hemip. Fabr. 1 : 90.

Lyctocoris carnpestris : Reuter, 1871. Öf. Vet. Aka. Förh. 28: 409.

Cimex pallidus Rossi, 1794. Mant. Ins. 2: 55.

Lygaeus arvicola Latreille, 1804. Hist. Nat. Crust. Ins. 12: 220.

Phytocoris pallens Fall\&, 1829. Hemip. Suec., Cimic. p. 103.

Cimex domesticus Schilling, 1834. Isis p. 738.

Lyctocoris domesticus Hahn, 1835. Wanz. Ins. 3: 20. 
Anthocoris domesticus : Herrich-Schaeffer, 1853. Wanz. Ins. 9: 228. Anthocoris bicuspis Herrich-Schaeffer, 1835. Nomen. Ent. 1: 60. Xylocoris dimidiata Spinola, 1840. Ess. Hemp. p. 236.

Xylocoris parisiensis Amyot \& Serville, 1843. Hemip., p. 264. Xylocoris americanus Dallas, 1852. List Hemip. 2 : 589.

Cardiastethus currax Garbiglietti, 1869. Bull. Ent. Ital. 1 : 123.

Lyctocoris fitchii Reuter, 1871. Öf. Vet. Aka. Förh. 28 : 557.

Cosmopolitan.

4. Lyctocoris canadensis Kelton

Lyctocoris canadensis Kelton, 1967. Can. Ent. 99 (8) : 807.

Canada.

5. Lyctocoris cohici Delamare

Lyctocoris cohici Delamare, 1952. Encyl. Biogeogr. ecol. 8: 81. Ivory coast.

6. Lyctocoris doris Van Duzee

Lyctocoris doris Van Duzee, 1921. Proc.Calif.Acad. Sci. 11 : 137.

Canada, U. S. A.

7. Lyctocoris dorni E. Wagner

Lyctocoris dorni E. Wagner, 1941. Gulde, Wanz. 8: 223.

Europe, Syria.

8. Lyctocoris elongatus (Reuter)

Dolichomerus elongatus Reuter, 1871. Öf. Vet. Aka. Förh. 28: 558.

Lyctocoris elongatus Reuter, 1884. Monog. Anthoc. p. 565.

u. S. A.

9. Lyctocoris hasegawai Hiura

Lyctocoris hasegawai Hiura, 1966. Bull. Osaka Mus. Nat. Hist. 19 : 36. Formosa.

10. Lyctocoris hawaiiensis (Kirkaldy)

Nesidiocheilus hawaiiensis Kirkaldy, 1902. Fauna Hawaii. 3 (2) : 93.

Lyctocoris hawaiiensis : Zimmerman, 1948. Ins. Hawaii. 3: 174.

Hawaii.

11. Lyctocoris latus Poppius

Lyctocoris Zatus Poppius, 1909. ActaSoc. Sci. Fenn. 37 (9) : 42. Peru.

12. Lyctocoris longirostris Horváth

Lyctocoris longirostris Horváth, 1911. Bull. Mus. Paris p. 216.

Dahomey.

13. Lyctocoris lugubris Poppius

Lyctocoris lugubris Poppius, 1909. Acta Soc. Sci. Fenn. 37 (9) : 42. 
West Africa.

14. Lyctocoris mexicanus Kelton

Lyctocoris mexicanus Kelton, 1966. Can. Ent. 98 (3) : 320.

Mexico.

15. Lyctocoris nidicola E. Wagner

Lyctocoris nidicola E. Wagner, 1955. Notul. Ent. 35 (2): 61.

Finland.

16. Lyctocoris obsoletus (Blanchard)

Anthocoris obsoletus Blanchard, 1852. Illist de Chile 2001. 7: 140.

Lyctocoris obsoletus: Signoret, 1863. Ann. Soc. Ent. Fr. p. 566.

Chile.

17. Lyctocoris okanaganus Kelton \& Anderson

Lyctocoris okanaganus Kelton \& Anderson, 1962. Can. Ent. 94 (12): 1302.

Canada, U. S. A.

18. Lyctocoris rostratus Kelton \& Anderson

Lyctocoris rostratus Kelton \& Anderson, 1962. Can. Ent. 94 (12) : 1302.

Canada, U. S. A.

19. Lyctocoris signoreti Reuter

Lyctocoris signoreti Reuter, 1884. Monog. Anthoc. p. 563.

Venezuela.

20. Lyctocoris spangbergi Reuter

Lyctocoris spangbergi Reuter, 1884. Monog. Anthoc. p. 562.

Venezuela.

21. Lyctocoris stalii (Reut er)

Dolichomerus stalii Reuter, 1871. Öf. Vet. Aka. Förh. $28: 558$.

Dolichomerus reuteri White, 1879. Ent. mon. Mag. 16: 146.

Lyctocoris stalii Reuter, 1884. Monog. Anthoc. p. 564.

Canada, U. S. A.

22. Lyctocoris subelegans Breddin

Lyctocoris subelegans Breddin, 1928. Denskschr. Med. Ges. Naturw. Jena 17: 81. South Africa.

23. Lyctocoris tuberosus Kelton \& Anderson

Lyctocoris tuberosus Kelton \& Anderson, 1962. Can. Ent. 94 (12) : 1302.

Canada, U. S. A.

24. Lyctocoris uyttenboogaati Blöte

Lyctocoris nyttenboogaati Blöte, 1926. Tidsk. Ent. 72: 163.

Canary Is.

The Palaearctic and Oriental species are characterized by the following 
key (almost followed Wagner (1955)).

la Vertex narrower than twice of eye width.

L. hasegawai

b Vertex wider than twice of eye width

L. dorni

2a Vertex 2-2.2 times as wide as an eye.

b Vertex 2.6-3.1 times as wide as an eye.

a Second segment of antennae distinctly longer than width of head.

4a Lateral margins of pronotum marginated, cuneus shallowly punctate.

L. campestris

b Lateral margins of pronotum not marginated, cuneus rugose not punctuated.

5a Vertex 2.9-3.0 times as wide as eye, length of posterior margin of pronotum about 1.5 times as long as anterior margin,

L. nidicola

b Vertex 2.6-2.7 times as wide as eye, length of posterior margin of pronotum about 2.0 times as long as anterior margin.

L. uyttenboogaati

The taxonomical studies of $L$. beneficus was first made dy Hiura (1957, 1966), and his former paper contains the descriptions of adult and nymphs.

\section{Description of $L$. beneficus :}

Egg. The egg of $\boldsymbol{L}$. beneficus is elongate and slightly curved. It is rounded at one end and provided with chalky white operculum at the opposite end. The operculum is roughly circular in outline and divided into two distinct zones. The marginal zone consists of a ring of radially elongate "cells" roughly rectangular in shape, such columner system composed of about 27 cells. In width this zone occupies approximately half the diameter of the operculum. The second or inner zone is slightly convex provided with 15-20 rounded processes. The operculum is normally the only portion exposed on the filter paper in laboratory condition, and chalky white in appearance in a newly oviposited egg, while the colour changes to pinkish red hue after several hours of oviposition.

Average $1.15 \mathrm{~mm}$ in length (range 1.13-1.18), and $0.35 \mathrm{~mm}$ in width (range 0.32-0.37).

First instar. Immediately after the eclosion, the nymph is pale yellow in coloration. Head : pale yellow with eyes deeper brilliant red colour, sutures obscurely visible; antennal segments I-III darker in colour, IV nearly colourless or very pale straw-coloured, diameters of segments subequal; rostrum pale orange in colour while dark grey in distal part, and much shorter than antennae or about three-fourths as long as antennae. Thorax : in general colour more dusky than head ; pronotum pale yellowish, rectangular in shape; mesonotum with a pale yellowish widening posteriorly; mesonotum pale yellow, paler than the preceding, lateral parts of thoracic segments deeply tinged. Legs : pale yellow, femora slightly darker than tibiae and tarsi. Abdomen :orangered with two long ciliae on the last segment.

Second instar. Head : brownish yellow, eyes brownish red, suture pale and well marked ; antennae pale, suffused with dusky brown, especially on distal part of segment I, entire part of II and base of IV, III and IV more slender than I and II in diameter, III and IV with prominent hairs: rostrum brownish, deeper on distal part. Thorax: all segments yellowish with slightly brownish tinge, margins with reddish tinge; wing-pads slightly 
observable. Legs yellow with dusky suffusion. Abdomen: segments I and II yellow as in thorax; remainder pale, with dark internal organs visible through the hinder part of integument, posterior margin of the last segment pinky tinged, with two developed long ciliae.

Third instar. Head : brownish yellow with pale sutures; eyes red, surrounded by a dirty brown green area; antennal segments I-III dusky grey, with pale distal parts on segments II and III, the basal one-third of segment IV dull grey ; rostrum yellowish brown, distal part deep brown. Thorax: dirty brown yellow with a pair of large dirty yellow-green areas on the sides of a longitudinal central line, tinge of the area slightly lighter on mesonotum ; wing-pads nearly extending to the posterior margin of the first abdominal segment. The anterior margin of segment II approaching to wing-pads with pinky hue. Legs: dusky grey, similar in colour to basal part of pronotum, dusky grey in the antero-dorsal part of each femur. Abdomen : segments I-III dark yellowish brown, remaining segments deep in colour with dirty brown area at the central part, terminal cilia absent.

Fourth instar. Head : colour as in the preceding instar, but more brownish, suffused with dark tinged ; eyes red ; antenna1 segments I-III dark grey to black with distal one-eighth of II, III pale cream coloured, IV pale coloured, slightly dark distally. Thorax: colour as in the third instar but more brown tinged; wing-pads more developed, exceeding beyond the posterior margin of first abdominal segment. Legs: pale testaceous with greyblack suffusion. Abdomen: colour as in the third instar.

Fifth instar. Head: deep dark brown coloured ; antennal segments, I-III dark grey to black, with distal extremities narrowly pale creamy white, greyish hue most distinct on III, IV dark grey on basal part, remainder brownish-yellow; rostrum darker at median part, with one pinkish area on each lateral side of the base. Thorax : pronotum deep brownish black coloured, becoming darker laterally: mesonotum and metanotum brown coloured medially, dark red-brown on antero-lateral regions, becoming yellowishbrown posteriorly on wing-pads. Legs: testaceous with dark grey suffusion, especially on femora and fore-tibia. Abdomen: yellowish brown with large black area except the last segment, the area on segments VII, VIII and VIII separated in mesial part, segment I very faintly pink. Fore wing-pads entirely covering hind wing-pads, extending to middle of segment II.

Adult. Head: black, distal part pale brown, upper surface coarsely punctate, except oral area and around eyes, ventral surface reddish black; eyes deep brown; antennae with all segments dark brown except basal part of II which is yellow brown, with distinct hairs, hairs on III and IV longer than diameter of the segments; rostrum brown in colour, reaching the posterior margin of mesonotum. Thorax: pronotum subtrapezoidal, with a longitudinal median canal, anteriorly levigate, with two large triangular depressions posteriorly, anterior margin curved a little, posterior margin markedly sinuate, about three times as wide as anterior margin, lateral margins gently curved, scutellum wider than long, $4: 3$ in proportion, divided by a transverse sulcus into an anterior raised and rounded portion and a posterior portion with transverse striations. Osteolar channel curved forwardly at a right angle, running parallel with outer margin and extending to anterior margin of pleuron. Elytra coarsely punctate, cuneus smooth, clavus and cuneus wide, embolium comparatively narrow, membrane with four subparallel veins, anterior one distinct. Legs: very dark brown apex of fore- and middle-tibia each with a distinct small spongy furrow, tarsi dark brown or black, three- segmented. 
The measurements of body parts of each stage are given in Tables 2-4.

Table 2. Lyctocoris beneficus; dimensions of nymphs and adult in millimeters. (I)

\begin{tabular}{clccccc}
\hline $\begin{array}{c}\text { Instar } \\
\text { No. }\end{array}$ & $\begin{array}{c}\text { Head } \\
\text { length }\end{array}$ & $\begin{array}{c}\text { Head } \\
\text { width }\end{array}$ & $\begin{array}{c}\text { Pronotum } \\
\text { length }\end{array}$ & $\begin{array}{c}\text { Pronotum } \\
\text { width }\end{array}$ & $\begin{array}{c}\text { Abdomen } \\
\text { length }\end{array}$ & $\begin{array}{c}\text { Total } \\
\text { length }\end{array}$ \\
\hline 1 & 0.24 & 0.22 & 0.13 & 0.25 & 0.45 & 1.10 \\
2 & 0.27 & 0.23 & 0.18 & 0.37 & 0.85 & 1.86 \\
3 & 0.38 & 0.36 & 0.32 & 0.63 & 1.10 & 2.53 \\
4 & 0.39 & 0.36 & 0.36 & 0.74 & 1.62 & 2.92 \\
5 & 0.41 & 0.39 & 0.44 & 0.91 & 2.08 & 3.72 \\
Adult & 0.46 & 0.54 & 0.69 & 1.27 & 2.12 & 3.84
\end{tabular}

(Avg of 5 individuals).

Table 3. Lyctocoris beneficus; dimensions of nymphs and adult in millimeters. (II)

\begin{tabular}{|c|c|c|c|c|c|c|c|c|c|c|}
\hline \multirow{2}{*}{$\begin{array}{c}\text { Instar } \\
\text { No. }\end{array}$} & \multicolumn{5}{|c|}{ Antennal segments } & \multicolumn{5}{|c|}{ Rostra1 segments } \\
\hline & I & II & III & IV & total & I & II & III & IV & total \\
\hline 1 & 0.06 & 0.18 & 0.15 & 0.16 & 0.55 & 0.03 & 0.10 & 0.18 & 0.13 & 0.44 \\
\hline 2 & 0.09 & 0.27 & 0.21 & 0.24 & 0.81 & 0.05 & 0.15 & 0.27 & 0.18 & 0.65 \\
\hline 3 & 0.12 & 0.32 & 0.25 & 0.30 & 0.99 & 0.08 & 0.18 & 0.36 & 0.24 & 0.86 \\
\hline 4 & 0.16 & 0.36 & 0.26 & 0.34 & 1.12 & 0.09 & 0.21 & 0.40 & 0.26 & 0.96 \\
\hline 5 & 0.17 & 0.51 & 0.32 & 0.35 & 1.30 & 0.11 & 0.26 & 0.48 & 0.30 & 1.15 \\
\hline Adult & 0.19 & 0.58 & 0.39 & 0.39 & 1.54 & 0.11 & 0.35 & 0.54 & 0.39 & 1.38 \\
\hline
\end{tabular}

Table 4. Lyctocoris beneficus; dimensions of nymphs and adult in millimeters, (III)

\begin{tabular}{ccccccccccc}
\hline $\begin{array}{c}\text { Instar } \\
\text { No. }\end{array}$ & \multicolumn{2}{c}{ Fore leg } & \multicolumn{3}{c}{ Middle leg } & \multicolumn{2}{c}{ Hind leg } \\
& Femur & Tibia & Tarsus & Femur & Tibia & Tarsus & Femur & Tibia Tarsus \\
1 & 0.21 & 0.16 & 0.11 & 0.20 & 0.10 & 0.04 & 0.25 & 0.20 & 0.08 \\
2 & 0.38 & 0.33 & 0.18 & 0.34 & 0.37 & 0.13 & 0.51 & 0.56 & 0.21 \\
3 & 0.53 & 0.47 & 0.25 & 0.52 & 0.48 & 0.23 & 0.72 & 0.75 & 0.24 \\
4 & 0.61 & 0.54 & 0.26 & 0.55 & 0.58 & 0.26 & 0.76 & 0.87 & 0.25 \\
5 & 0.77 & 0.73 & 0.27 & 0.68 & 0.64 & 0.27 & 1.01 & 1.04 & 0.26 \\
Adult & 0.77 & 0.77 & 0.28 & 0.92 & 0.65 & 0.28 & 1.15 & 1.09 & 0.27
\end{tabular}

(Avg of 5 individuals). 
Each instar of $\boldsymbol{L}$. beneficus nymphs is easily distinguishable by the following key.

1 a Posterior margin of abdomen with cilia. .................................................... 2

b Posterior margin of abdomen without cilia. .............................................. 3

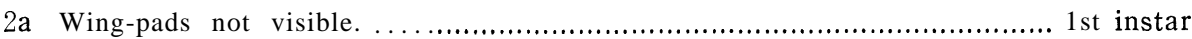

b Wing-pads slightly visible. .......................................................... 2nd instar

3a Wing-pads not exceeding posterior margin of the first abdominal segment.

3rd instar

b Wing-pads exceeding posterior margin of the first abdominal segment. . . . . . . . 4

4a Hind wing-pads partly covered with fore ones, without black brown areas on dorsal suface of 1 st and 2nd abdominal segments. ................................. 4th instar

b Hind wing-pads entirely covered with fore ones, with black brown area on dorsal surface of abdomen, especially prominent on 1st and 2nd segments.

5 th instar

The genus Xylocoris Dufour was erected to contain a single species rufipennis by Dufour (1831). In 1833, Dufour added the second species, X. ater which was later moved to the genus Dufouriella by Kirkaldy. Since then, many species had been included in this genus. On the other hand, Fieber (1861) erected a new genus Piezostethus designating $P$. cursitans as the haplotype. Later Piezostethus was proved to be a synonym of Xylocoris by Kirkaldy (1906).

\section{Genus Xylocoris Duf our}

Haplotype rufipennis Duf. = cursitans (Fall\&).

Dufour, 1831. Ann. Sci. Nat. Paris 22: 423.

Dufour, 1833. Ann. Soc. Ent. Fr. 1 (2) : 106.

Burmeister, 1835. Handb. d'Ent. 2 : 289.

Spinola, 1837. Ess. Hemip. p. 235.

Amyot \& Serville, 1843. Hemip. p. 235

Herrich-Schaeffer, 1853. Wanz. Ins. $9: 170$

Stål, 1865. Hemip. Afr. $3: 23$.

Kirkaldy, 1906. Trans. Am. Ent. Soc. 32 : 119.

Reuter, 1912. Öf. Fin. Vet. Soc. Fork. Liv. Afd. (A) 7: 25 .

Van Duzee, 1917. Cat. Hemip. Am. N. Mexico p. 290.

Blatchley, 1926. Heter. E-N. Am. p. 627 .

Zimmerman, 1946. Ins. Hawaii. 3: 175.

Herring, 1967. Ins. Micronesia 7 (8) : 142.

\section{Genus Piezostethus Fieber}

Fieber, 1869. Wien Ent. Monat. 4: 365.

Fieber, 1861. Europ. Hemip. pp. 38, 139.

Douglas \& Scott, 1865. Brit. Hemip. p. 500.

Reuter, 1871. Öf. Vet. Aka. Förh. 28: 410.

Reuter, 1884. Monog. Anthoc. p. 29.

Champion, 1900. Biol. Centr. Am. Heter. 2: 315. 
Oshanin, 1909. Verz. palae. Hemip. 1: 615.

Banks, 1910. Cat. Nearc. Hemip. p. 24.

The genus Xylocoris is characterized by the following features:

Small, oval or oblong-oval, subglabrous shining, having the head about as long as wide across the eyes, hidden in thorax almost to eyes, eyes large, ocellus distinct and situated close to the base of eyes. Rostrum reaching to or rather beyond the base of mesonotum, 1 st segment about $1 / 2$ the length of head; 2nd about $21 / 2$ times longer than the $1 \mathrm{st}$; 3rd about as long as the 1 st. First segment of antennae cylindrical, very short, not reaching to the apex of head, 2nd gradually clavate, about $21 / 2$ times as long as the $1 \mathrm{st}$; 3rd and 4th thin, filiform, subequal in length, taken together much longer than the second. Pronotum subtrapezoidal, without an apical constriction, smooth and shining, hind margin feebly sinuate or subtruncate, with a transverse post-median impression, sides in front of middle strongly deflexed, not margined or ciliated, base sinuate, scutellum nearly flat, slightly concave. Hemielytra usually dimorphic, in macropterous form elongate, parallel-sided, membrane with distinct veins, reaching tip of abdomen, in brachypterous form not further back than fourth abdominal segment, legs short, femora slightly incrassate, especially on fore legs, front tibiae of males much enlarged near apex, obliquely truncate, spinose beneath. Osteolar channel long, curved forwards from middle, extending almost or quite anterior margin of metapleura.

This genus includes 38 species, 23 from Palaearctic, 9 from Nearctic, 5 from Neotropical, 5 from Australasian, 4 from Oriental, and 8 from Ethiopian Regions. Among them 2 species are known as cosmopolitan species.

1. Xylocoris albonotatus (Champion)

Piezostethus albonotatus Champion, 1900. Biol. Centr. Am. Heter, 2:316.

Guatemala, Panama.

2. Xylocoris afer (Reuter)

Piezostethus afer Reuter, 1884. Monog. Anthoc. p. 592.

Tunisia, South Africa, Egypte.

3. Xylocoris antaoensis E. Wagner

Xylocoris antaoensis E. Wagner, 1957. Comm. Biol. Helsing. 16 (2) : 3.

Cape Verde Is.

4. Xylocoris balteatus Walker

Xylocoris balteatus Walker, 1872. Cat. Heter. Brit. Mus. 5: 159.

Piezostethus balteatus: Reuter, 1884. Monog. Anthoc. p. 714.

Madeira.

5. Xylocoris betulinus Drake \& Harris

Xylocoris betulinus Drake \& Harris, 1926. Proc. Biol. Soc. Wash. 39 : 37.

U. S. A.

6. Xylocoris bimaculatus (Champion)

Piezostethus bimaculatus Champion, 1900. Biol. Centr. Am. Heter. 2: 316. 
Guatemala.

7. Xylocoris californicus (Reut er)

Piezostethus californicus Reuter, 1884. Monog. Anthoc. p. 600.

Canada, U. S. A.

8. Xylocoris canariensis E. Wagner

Xylocoris canariensis E. Wagner, 1955. Comm. Biol. Helsing. 14 (2) : 27.

Canary Is.

9. Xylocoris ciliatus (Jakovlev)

Piezostethus ciliatus Jakovlev, 1877. Bull. Soc.Mosc. 52 (2) : 300.

U. S. S. R.

10. Xylocoris congoensis (Bergroth)

Piezostethus congoensis Bergroth, 1905. Ann. Soc. Ent. Belg. (1905) : 386.

Congo.

11. Xylocoris contiguus E. Wagner

Xylocoris contiguus E. Wagner, 1955. Comm. Biol. Helsing. 14 (2) : 24.

Canary Is.

12. Xylocoris cursitans (Fallén)

Lygaeus cursitans Fallén, 1807. Mon. Cimic.Suec.p. 74 .

Anthocoris cursitans Fallén, 1829. Hem. Suec. p. 69.

Xylocoris cursitans : Sahlberg, 1848. Monog. Geor. Fenn. p. 80.

Piezostethus rufipennis Dufour, 1833. Ann. Soc. Ent. Fr. 2: 106.

Lyctocoris corticalis Hahn, 1835, Wanz. Ins. $3: 21$.

Xylocoris bicolor Schultz, 1846. Uebers Schles. Ges. (1846) : 116.

Xylocoris latior Mulsant, 1852. Ann. Soc. Linn. Lyon p. 160.

Piezostethus cursitans : Reuter; 1871. Öf. Vet. Aka. Förh. p. 411.

Cosmopolitan.

13. Xylocoris deserti Villiers

Xylocoris deserti Villiers, 1918. Bull. Inst. Franz. Afr. Noir (A) 18: 838.

Mauritania.

14. Xylocoris discalis (Van Duzee)

Scoloposcelisdiscalis Van Duzee, 1914. Trans. San Diego Soc. Nat. Hist. 2: 15.

Hawaii, U. S. A.

15. Xylocoris dybasi Herring

Xylocoris dybasi Herring, 1967. Ins. Micronesia 7 (8) : 413.

Mariana Is.

16. Xylocoris flaccidus (Van Duzee)

Piezostethus flaccidus Van Duzee, 1914. Trans. San Diego Soc. Nat. Hist. 2: 14.

U. S. A. 
17. Xylocoris flavipes (Reuter)

Piezostethus flavipes Reuter, 1875. Sv. Aka. Handl. 3 (1) : 65.

Triphleps frumenti Zacher, 1922. Arb. Biol. Reichanst. Land und Forst Wirt. $12: 236$.

Triphleps sinui Narayanan \& Chatterji, 1952. Proc. 2001. Soc. Bengal 5 (2): 163, Triphleps ramae Narayanan \& Chatterji, 1953. Proc. 2001. Soc. Bengal 6 (2) : 121. Europe, Algeria, South Africa, India.

18. Xylocoris formicetorum (Boheman)

Anthocoris formiceluman, 1844. Öf. Aka. Förh. 1: 158.

Xylocoris formiceticola Sahlberg, 1848. Mon. Geoc. Fenn. p. 82.

Xylocoris coenomyces Baerensprung, 1858. Berl. Ent. Zeit. 2: 195.

Piezostethus formicetrum : Fieber. 1861. Europ. Hemip. 139 : 2.

Europe, Algeria.

19. Xylocoris galactinus (Fieber)

Anthocoris galactinus Fieber, 1836. Weit. Beit. 1 (107) : 7 .

Anthocoris pulchellus Fieber, 1840. Zett. Ins. Lap. 265: 3.

Piezostethus albipennis Herrich-Schaeffer, 1853. Wanz. Ins. 9:173.

Piezostethus galactinus Fieber, 1861. Europ. Hemip. $139: 1$.

Cosmopolitan.

20. Xylocoris heluanensis E. Wagner

Xylocoris heluanensis E. Wagner, 1961. Bull. Soc. Ent. Egypte 45: 301.

Egypt.

21. Xylocoris hirsutus Carayon

Xylocoris hirsutus Carayon, 1961. S. Afr. Anim. life 3:550.

South Africa, Kenya.

22. Xylocoris jeanneli (Poppius)

Piezostethus jeanneli Poppius, 1920. Voyage Alluaud Hemip. 4: 322.

East Africa.

23. Xylocoris lativentris (Sahlberg)

Piezostethus lativentris Sahlberg, 1861. Not. Pro. Faun. Flor. Fenn. 9: 287.

North Europe, Bulgaria.

24. Xylocoris machadoi (Carvalho)

Piezostethus machadoi Carvalho, 1952. Publ. Cult. Comp. Diam. Angola 15: 19.

Angola.

25. Xylocoris maculipennis Baerensprung

Xylocoris maculipennis Baerensprung, 1858. Berl. Ent. Zeit. 2 :197.

Piezostethus maculipennis: Reuter, 1883. Ent. Tidsk. 4: 137.

North Africa, Syria, South Europe.

26. Xylocoris nigritulus (Reut er) 
Piezostethus nigritulus Reuter, 1877. Öf. Finsk. Vet. Soc. 21 (40) : 19.

Piezostethus nigricans Reuter, 1877. Öf. Finsk. Vet. Soc. 21 (40) : 19.

Xylocoris formicetorum : Baerensprung, 1858. Berl. Ent. Zeit. 2 : 195.

Germany.

27. Xylocoris obliquus Cost a

Xylocoris obliquus Costa, 1852. Cent. 7 (241) : 28.

Piezostethus signatus Jakovlev, 1882. Troudy Ent. Ross. 12: 148.

Piezotethus obliquus : Reuter, 1884. Monog. Anthoc. p. 591.

var. orientalis Reuter, 1884. Monog. Anthoc. p. 591.

Europe, Syria.

Morocco, Syria, Persia. (var. orientalis)

28. Xylocoris pallidipes (Poppius)

Piezostethus pallidipes Poppius, 1920. Voyage Alluaud Hemip. $4: 3$.

East Africa.

29. Xylocoris parvulus (Reut er)

Piezostethus parvulus Reuter, 1871. Notis. Skpts. pro. Faun. et Flora Fenn. 11: 321.

Finland, Holland, Hungary.

30. Xylocoris piceus (Reut er)

Piezostethus piceus Reuter, 1884. Monog. Anthoc. p. 590.

Siberia.

31. Xylocoris queenslandicus Gross

Xylocoris queenslandicus Gross, 1956. Rec. S. Aust. Mus. 11:151.

Australia.

32. Xylocoris spangnicola (Reut er)

Piezostethus spangnicola Reuter, 1883. Ent. Tidsk. 4:135.

Finland.

33. Xylocoris sordidus (Reut er)

Piezostethus sordidus Reuter, 1871. Öf. Vet. Aka. Förh. 28: 560.

Piezostethus binotatus Reuter, 1871. Öf. Vet. Aka. Förh. 28: 560.

U. S. A., Central and South America.

34. Xylocoris terricola (Reut er)

Piezostethus terricola Reuter, 1902. Ent. mon. Mag. 38 : 102.

Spain.

35. Xylocoris thomsoni (Reuter)

Piezostethus thomsoni Reuter, 1883. Ent. Tidsk. 4 : 137.

Sweden, U. S. S. R.

36. Xylocoris transversus E. Wagner

Xylocoris transversus E. Wagner, 1955. Comm. Biol. Helsing. 14 (2) : 22. 


\section{Canary Is.}

\section{Xylocoris umbrinus Van Duzee}

Xylocoris unbrinus Van Duzee, 1921. Proc.Calif.Acad. 4 (11): 137.

Canada, U. S. A.

\section{Xylocoris vicarius (Reuter)}

Xylocoris vicarius Reuter, 1884. Monog. Anthoc. p. 599.

Canada, U. S. A.

The Palaearctic and Oriental species are characterized by the following key.

Ia Base of pronotum strongly sinuate, sides of pronotum anteriorly marginate. ...... 2

b Base of pronotum very widely and slightly sinuate or subtruncate, not marginate at sides.

2a First segment of rostrum extending to base of eye, antennal segment III as long as segment II.

X. maculipennis

b First segment of rostrum only reaching to the middle of eye, antennal segment III shorter than segment II. ............................................................... X. lativentris

3a Apex of abdomen free from long protruded hair, legs somewhat long, fairly slender, entirely pale yellow. .................................................................. 4

b Apex of abdomen furnished with long protruding hairs, legs somewhat short, fairly robust, femora mostly pitchy-black or brown.

$4 a$ Osteolar channel reaching to anterior margin of pleura.

b Osteolar channel not reaching to anterior margin but to lateral margin of pleura.

$\mathrm{X}$. transversus

5a Osteolar channel very long, forming a carinate and acuminate apex which is reaching to basal margin of pleura.

b Osteolar channel not strongly and acuminately prolonged near apex, ending a little below of basal margin of pleura.

6a Posterior tibiae with long fine white hairs.

X. parvulus

b Posterior tibiae with short hairs. ….......................................................... 7

7a Large-sized species at least $21 / 2 \mathrm{~mm}$ in length. ........................................... 8

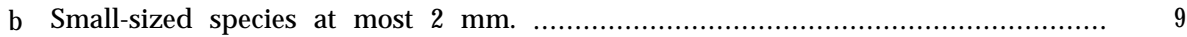

8a Hemielytra whitish, partly brownish. ...................................... $X$. galactinus

b Hemielytra except interior angle brown or pitch black ......................... X. afer

9a Antenna entirely pale yellow testaceous, legs entirely yellow testaceous.

b Antenna pitch-black, femora except apex blackish......................... X. spangnicola

10a Hemielytra entirely $f$ uscous. ...................................................................... 11

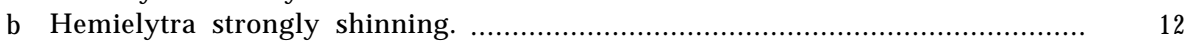

Ila Hind tibiae with marked long hairs.................................... X. contiguus

b Hind tibiae without long hairs. ........................................................ X. piceus

12a Hemielytra pitch black, corium except for apex and frequently embolium blue whitish. ................................................................................................... 13

b Hemielytra unicolous, strongly shortened, its apex truncate. ............................... 16

13a Body size less than $1.8 \mathrm{~mm}$, apex of mesocorium black ............................. 14

b Body size more than $2.4 \mathrm{~mm}$, apex of mesocorium shining....................... 15 


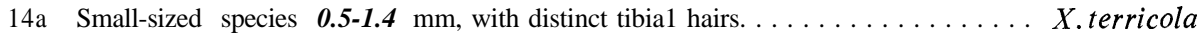

b Large-sized species 1.4-1.8 $\mathrm{mm}$, without distinct tibia1 hairs.

X. heluanensis

15a Pronotum strongly slender anteriorly, lateral margin of pronotum linear.

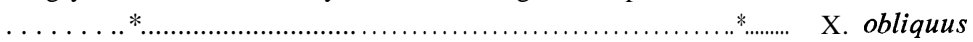

b Pronotum not markedly slender anteriorly, lateral margin of pronotum widely si-

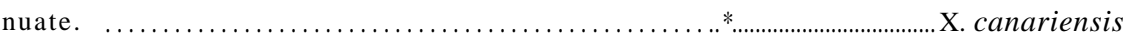

16 a Large-sized species, oblong oval, at least $21 / 2 \mathrm{~mm}$ in length, abdomen not strongly

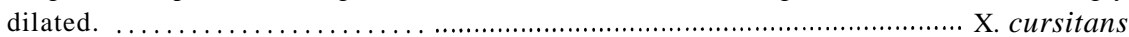

b Small-sized species, short-oval, at most $11 / 2 \mathrm{~mm}$ in length, abdomen strongly dilated.

X. thomsoni

Note: From the above key the following six species are excluded.

X. antaoensis E. Wagner, 1957. Comm. Biol. Helsing. 16 (2) : 3.

X. balteatus Walker, 1872. Cat. Heter. Brit. Mus. 5 : 159.

X. ciliatus (Jakovlev, 1877). Bull. Soc. Mosc. 52 (2) : 300.

X. deserti Villiers, 1918. Bull. Inst. Franz. Afr. Noir (A) $18: 838$.

X. machadoi (Carvalho, 1952). Publ. Cult. Comp. Diam. Angola 15 : 19.

X. nigritulus (Reuter, 1877). Öf. Finsk. Vet. Soc. 21 (40) : 19.

Description of the adult of X. galactinus was first treated by Fieber (1836). Since then, redescriptions have been made by Reuter (1884), Blatchley (1926), Carayon (1953) etc., and works on nymphal stages were done by Hall (1951).

\section{Description of X. galactinus :}

Egg. The egg of $X$. galactinus is elongate and slightly curved. It is rounded at one end and provided with an operculum at the opposite end. The operculum is roughly circular in outline, and divided into two distinct zones as in the case of many Anthocorid bugs. The marginal zones consists of about 22 rectangular cells which are arranged radially around the inner zone, but varying somewhat in detail. In width this zone is approximately half the diameter of operculum. The second or inner zone is slightly convex and composed of flattened area with a number of fine protuberances. The operculum is chalky white in coloration and the main portion is exposed on the filter paper in which the egg is deposited in laboratory condition. The sculpture of operculum differs distinctly from that of $\boldsymbol{L}$. beneficus.

Average $0.66 \mathrm{~mm}$ in length (range 0.64-0.69), and $0.32 \mathrm{~mm}$ in width (range 0.29-0.34).

First instar. Immediately after the eclosion the nymph is pale pinky colour but soon becomes darker. Head : pale yellow with dusky suffusion, eyes deeper red colour, sutures clearly visible ; antennal segments I-III with grey tinge, IV translucent. Thorax : generally more dusky than head; pronotum rectangular in shape; mesonotum widening posteriorly, anterior margin of pro- and mesonota with pinky tinge; metanotum paler than aforementioned. Legs: almost translucent with femora slightly darker than tibiae and tarsi. Abdomen: pale yellowish, lateral parts of anterior half pink tinged, mesial part of segments III-IV with distinct pink speckles, with 4 long setae on abdominal tip.

Second instar. Head : reddish orange, eyes red, suture pale and well marked ; antennae translucent, suffused with dusky grey except for segment IV; rostrum yellowish, trans- 
lucent, slightly dusky grey on distal part. Thorax : all segments reddish, suffused with dirty grey. Legs : coloured as in the first instar, while slightly more brownish, hind tibiae with developed setae. Abdomen: reddish brown, pinkish tinge on lateral parts more distinct, speckles on segments III-VI red brown, terminal setae present.

Third instar. Head : dark brown with pinkish sutures, ventral surface reddish ; antennal segments I-III dusky grey with pale distal zones, distal part of segment IV yellowish, rostrum; dark brown, especially on basal part. Thorax: yellowish brown suffused with dusky grey hue, pronotum dark brown especially on shoulder parts, anterior part of mesonotum lighter in colour ; wing-pads just visible, showing dark margins, extending to middle of abdominal segment I. Legs : slightly brown, fore femora distinctly swolIen, antero-lateral parts of femora greyish. Abdomen : segments I-II yellowish brown, remainder deep brown, especially on posterior part of each segment, speckles disappeared, setae existing.

Fourth instar. Head : colour as described for the third instar; antennal segments I-III dark grey to black with distal one-eighth of II cream coloured, IV yellowish, slightly brownish distally. Thorax : colour as in the third instar, but more fuscous; wing-pads further developed. Legs: pale testaceous with grey-black suffusion. Abdomen : colour as in the third instar.

Fifth instar. Head: deep brown and pinkish red on dorsal and ventral surfaces respectively, eyes deep red ; antennal segments I-III dark grey to black, with distal extremities narrowly pale creamy white, IV yellowish, translucent on distal part ; rostrum brown, darker at tip and ventral surface. Thorax : pronotum deep brown, becoming darker laterally, mesonotum brown ; metanotum brown tinged on anterior portion, yellowish posteriorly with pinkish brown along posterior margin. Wing-pads exceeding posterior margin of first abdominal segment and fore wing-pads entirely covering hind ones. Legs : yellowish brown with dark grey suffusion. Abdomen : segments I and II yellowish in colour, with pinky suffusion, remainder of abdomen dark brown or rather approaching to black, terminal setae present.

Adult. Head : brownish black, thinly clothed with short fine yellowish hairs, compound eyes deep brown, ocelli somewhat brilliant red; antennal segments I dark brown, II yellowish brown, the tip fuscous, III and IV yellowish-brown, slender, subequally in length withprominent hairs which are longer than the diameter of the segments; rostrum yellowishbrown, long and extending to the fore coxae. Thorax : pronotum black brown, subtrapezoidal, with base about one third as wide as apex; postmedian transverse impression distinct mesially, subobsolete on sides; collar almost smooth and minutely rugose; side margins provided with two erect slender setae; scutellum with a triangle-shaped median depression wide and deep, both pronotum and scutellum covered with fine yellow hairs. Hemielytra very finely and sparsely pubescent, uniformly straw-yellow, with at most the tips of clavus and cuneus and other margins of membrane fuscous. Legs : femora very dark brown, tibiae yellowish brown, tarsi paler, 3-segmented, bristles on tibiae very prominent. Abdomen as pronotum in coloration, with terminal setae.

The dimension of each stage is given in Tables 5-7.

Each instar of X. galactinus nymphs is easily distinguishable by the following key.

Head longer than pronotum.

Head shorter than pronotum. 
Table 5. Xylocoris galactinus; dimensions of nymphs and adult in millimeters. (I)

\begin{tabular}{ccccccc}
\hline $\begin{array}{c}\text { Instar } \\
\text { No. }\end{array}$ & $\begin{array}{c}\text { Head } \\
\text { length }\end{array}$ & $\begin{array}{c}\text { Head } \\
\text { width }\end{array}$ & $\begin{array}{c}\text { Pronotum } \\
\text { length }\end{array}$ & $\begin{array}{c}\text { Pronotum } \\
\text { width }\end{array}$ & $\begin{array}{c}\text { Abdomen } \\
\text { length }\end{array}$ & $\begin{array}{c}\text { Total } \\
\text { length }\end{array}$ \\
\hline 1 & 0.17 & 0.17 & 0.15 & 0.28 & 0.48 & 0.88 \\
2 & 0.21 & 0.20 & 0.18 & 0.48 & 0.72 & 1.22 \\
3 & 0.23 & 0.21 & 0.32 & 0.60 & 1.12 & 1.86 \\
4 & 0.25 & 0.23 & 0.44 & 0.68 & 1.21 & 2.60 \\
5 & 0.28 & 0.26 & 0.48 & 0.80 & 1.30 & 2.81 \\
Adult & 0.31 & 0.42 & 0.50 & 0.89 & 1.46 & 2.92
\end{tabular}

(Avg of 5 individuals).

Table 6. Xylocoris galactinus ; dimensions of nymphs and adult in millimeters. (II)

\begin{tabular}{|c|c|c|c|c|c|c|c|c|c|c|}
\hline \multirow{2}{*}{$\begin{array}{c}\text { Instar } \\
\text { No. }\end{array}$} & \multicolumn{5}{|c|}{ Antenna1 } & \multicolumn{5}{|c|}{ Rostra1 segments } \\
\hline & I & II & III & I V & total & I & II & III & IV & total \\
\hline 1 & 0.03 & 0.10 & 0.10 & 0.14 & 0.37 & 0.01 & 0.06 & 0.12 & 0.08 & 0.27 \\
\hline 2 & 0.07 & 0.15 & 0.16 & 0.18 & 0.56 & 0.03 & 0.11 & 0.19 & 0.10 & 0.43 \\
\hline 3 & 0.10 & 0.24 & 0.24 & 0.21 & 0.79 & 0.05 & 0.13 & 0.29 & 0.13 & 0.60 \\
\hline 4 & 0.13 & 0.32 & 0.31 & 0.24 & 1.00 & 0.06 & 0.15 & 0.31 & 0.14 & 0.65 \\
\hline 5 & 0.15 & 0.35 & 0.32 & 0.26 & 1.08 & 0.08 & 0.17 & 0.32 & 0.14 & 0.71 \\
\hline Adult & 0.19 & 0.36 & 0.32 & 0.29 & 1.17 & 0.12 & 0.19 & 0.34 & 0.15 & 0.81 \\
\hline
\end{tabular}

(Avg of 5 individuals).

Table 7. Xylocoris galactinus ; dimensions of nymphs and adult in millimeter. (III)

\begin{tabular}{|c|c|c|c|c|c|c|c|c|c|}
\hline \multirow{2}{*}{$\begin{array}{c}\text { Instar } \\
\text { No. }\end{array}$} & \multicolumn{3}{|c|}{ Fore leg } & \multicolumn{3}{|c|}{ Middle leg } & \multicolumn{3}{|c|}{ Hind leg } \\
\hline & Femur & Tibia & Tarsus & Femur & Tibia & Tarsus & Femur & Tibia & Tarsus \\
\hline 1 & 0.13 & 0.12 & 0.02 & 0.13 & 0.12 & 0.02 & 0.13 & 0.14 & 0.04 \\
\hline 2 & 0.25 & 0.21 & 0.09 & 0.21 & 0.20 & 0.06 & 0.25 & 0.23 & 0.08 \\
\hline 3 & 0.38 & 0.25 & 0.12 & 0.36 & 0.33 & 0.13 & 0.39 & 0.38 & 0.14 \\
\hline 4 & 0.43 & 0.32 & 0.13 & 0.44 & 0.43 & 0.17 & 0.54 & 0.59 & 0.18 \\
\hline 5 & 0.54 & 0.44 & 0.22 & 0.48 & 0.46 & 0.22 & 0.66 & 0.71 & 0.24 \\
\hline Adult & 0.58 & 0.50 & 0.27 & 0.62 & 0.58 & 0.27 & 0.73 & 0.88 & 0.35 \\
\hline
\end{tabular}

(Avg of 5 individuals). 


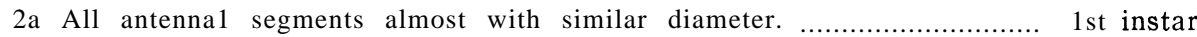

b Segments I-II thicker than segments III-IV .................................. 2nd instar

3a Hind wing-pads entirely covered with fore ones. ........................ 5th instar

b Hind wing-pads not entirely covered with fore ones. ............................. 4

4a Wing-pads just visible. ........................................................ 3rd instar

b Wing-pads developed and extending to the posterior margin of the first abdominal segment. .................................................................. 4 th instar

The adults of $\mathbf{L}$. beneficus and X. galactinus are easily discriminated by the following characters : 1) Larger body size, viz. about $3.8 \mathrm{~mm}$ in the former species, and less than $3.0 \mathrm{~mm}$ in the latter. 2) Distinguished cilia on the posterior margin of the abdomen in the latter species. 3) The front femora and tibiae more or less swollen in the latter species but not in $\mathbf{L}$. beneficus. The discrimination of the nymphal stage is somewhat difficult in the newly hatched nymphs between the two species. It is only distinguishable by the body size which are about 1.1 and $0.9 \mathrm{~mm}$ in $\mathrm{L}$. beneficus and $\mathrm{X}$. galactinus respectively. To distinguish the newly hatched nymphs more than one day old and the following instar nymphs, following characters are available.

1) Body size, as shown in Tables 2 and 5, larger in L. beneficus.

2) Coloration, light yellow to brown yellow in L. beneficus, more or less brilliant red-brown in $\mathbf{X}$. galactinus.

3) In L. beneficus, abdominal segment apparently dilated on the sides of IV-VI segments, thus making sub-spatulate in form. The dilation in $\mathrm{X}$. galactinus is not prominent and rather semi-ellipsoidally shaped.

4) In all nymphal stages of $X$. galactinus, the posterior margin of abdomen is provided with terminal ciliae while the ciliae are only present on the 1st and 2 nd instars in $L$. beneficus.

\section{Habitat}

According to the previous records, Lyctocoris beneficus (Hiura) was known to be abundant in a giant pile at Saga Paper Board Co. in Kyushu (Oho 1955a, b, Hiura 1957). Besides, Hiura (1957, 1966) examined the specimens of this species which were collected from the following habitats: farm store, thatch, piles of fire wood, grass (ex. Miscanthus sinensis), and harvested plants such as wheat, sweet potato, vine, broad-bean stem. Also some specimens were collected at the lamp during July to September.

Xylocoris galactinus (Fieber) is commonly known under the name of "hotbed bug", and in Europe it was found in manure-heaps, hot-bed, stable straw, grain bins, marsh haystacks and was also recorded on oak and beech and under the bark of other trees (Morley 1905, Butler 1923, Hall 1951, Southwood and Leston 1959, Sinha 1961 etc.). As the habitat of the bug, Reuter (1871a) wrote as follows: "Amongst decaying grass, on dung (Schiödte), with Myrmica calspitum (Bellevoye), on oak and beech, and under 
the bark of tree." Further, Fieber (1860) recorded "on plants in meadows." Of the habitat in Japan, Hiura (1966) recorded that "the bug lives in farm store of wheat straw, sometimes in the open air stacks of rice straw. Four specimens were obtained under the pile of dead sea grass on the beach. Often appearing at the lamp." In Micronesia, this species was collected from decaying coconuts (Herring 1967).

During the author's work, some individuals of both species of bugs were collected at the farm store in winter, while in the warmer season a great number of them were found in the giant straw piles at Saga Paper Board Co. Sometimes, the bugs were extremely abundant in paddy or wheat straw just transported to the Company yard from the farmer's stock yard or field piled thatch. L. beneficus was often much more predominant than $X$. galactinus on wheat straw which is generally more parched than paddy straw. The latter species was in almost all cases more prevalent in paddy straw especially of somewhat moist condition. The trials to collect the bugs in the paddy field and the grass meadow adjacent to the giant straw pile at Saga with a suction apparatus were failed. In August, many specimens of both species including nymphs were collected at the just harvested paddy straw at Kumamoto, in Kyushu, and this fact may indicate the occurrence of these bugs in the paddy field and the meadow nearby. During July to September many specimens of both species were also collected by the lamp. The nocturnal activities of both species will be given in detail in the later part of this report.

In conclusion, the author's observation indicates that L.beneficus is abundant in relatively dried places, while X. galactinus prefers rather marsh environment.

\section{Laboratory observation on the life history}

\section{Egg.}

Judging from their habitat in the field condition, paddy straw seems to be an important ovipositional substratum both for Lyctocoris beneficus (Hiura) and Xylocoris galactinus (Fieber). Under the laboratory condition, eggs are actually laid in the moist paddy straw which is provided for oviposition. On the other hand, eggs are also laid to the other materials such as the cherry twig, moist filter paper, molded cracked corn, moist vermiculite, etc. The oviposition preference by the adult females to these materials will be discussed in another column of this chapter. On the filter paper, eggs are inserted horizontally, causing the paper to bulge into a small but clearly visible blister which facilitates the location and counting of eggs. The operculum tends to face obliquely upwards because of the slight curvature of the egg. When the cherry twig is offered for the ovipositional substratum, the egg is oviposited just below the epidermis, exposing only 
a white sculptured operculum. When the twig is provided in an upright position, the adult female takes the position with the head upward in most cases, and lays eggs. Consequently, the egg operculum directs upwards. But rarely the egg was seen to be deposited the operculum downwards.

The range of incubation period is certainly affected by the temperature (Figs. 1\& 2). Hiura (1957) and Oho (1955c) indicated the incubation period
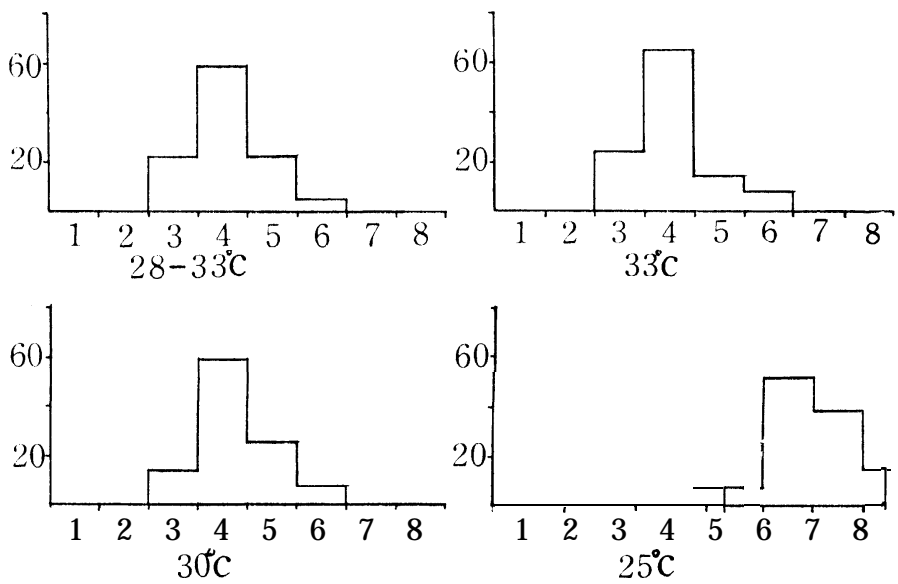

Fig. 1. Frequency distribution histograms of the incubation period of Lyctocoris beneficus.

Abscissa: time in days, Ordinate: Number of observations.
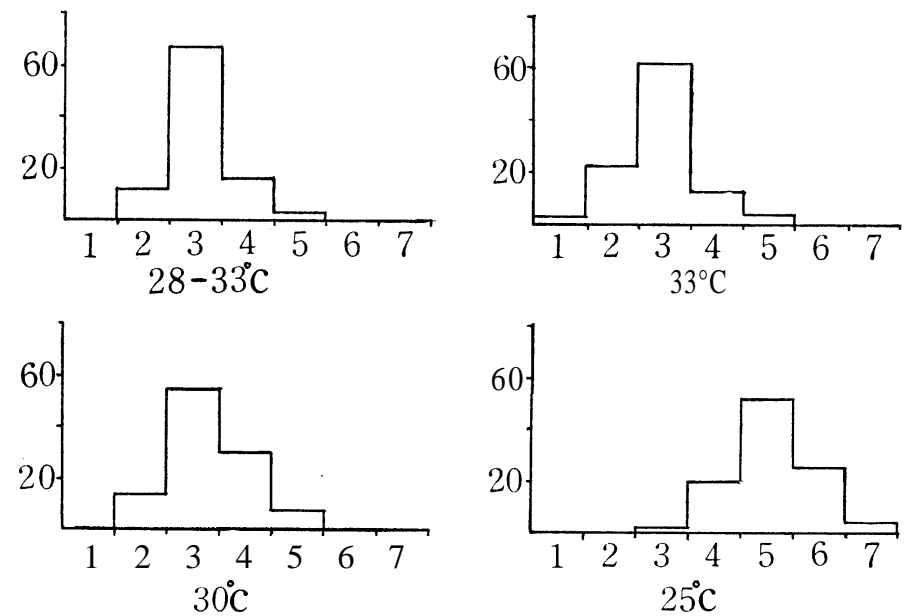

Fig. 2. Frequency distribution histograms of the incubation period of Xylocoris galactinus.

Abscissa : time in days, Ordinate : Number of observations. 
of L.beneficus for 7 and 6 days respectively. In the present work, majority of eggs of L.beneficus hatched after the incubation period of approximately 4 days under $30^{\circ} \mathrm{C}$ condition, and that of $X$. galactinus was 3 days. No significant effect was observed on the incubation period under the range of 53$100 \%$ of relative humidity. However, the water content of ovipositional substrata gives a great influence on the oviposition preference as well as the development of eggs. Namely, the adult does not lay any eggs on the dry substance. Moreover, if the egg supporting media dry up after the oviposition, the eggs fail to develop. Even if moderate humidity is supplied to the parched egg supporting media, few eggs resume their development and the rate of hatching is very low. The egg mortality in the dry substrata may be caused by the combination of two actions, one is the drought of egg itself, and another is the compression of egg by the desiccated substratum.

During the embryonic development, marked colour changes may be seen in the eggs of both species. The process of colour change is very similar in both species. But the change of colour in X.galactinus is slightly faster than that of L.beneficus owing to the shorter incubation period, and in the former species reddish tinge was always stronger than the latter species. The following is the description of colour change of the egg of L.beneficus under $30^{\circ} \mathrm{C}$ condition. At first, the egg is almost colourless and opalescent, showing slight pale orange tinge. This tinge becomes stronger and more extensive within 24 hours after oviposition. At the beginning of the second day, the posterior two-thirds of the egg becomes milky orange. At the end of the same day, the egg becomes entirely orange coloured except the anterior third which is still much paler than the rest. The egg is deep orange coloured at about one third of its length toward the operculum and also at the extreme tip. Later these concentrations may spread so that about half of the egg is tinged with orange. By the third day, they form two distinct zones, one occupying the posterior half of the egg and another forming a zone just behind the operculum from which it is separated by a narrow pale zone ; a broader pale orange zone separates the two deeper orange zones from each other. Toward that day, the entire egg becomes orange in colour, and orange tinge becomes deeper later, then reddish zones appear at a sub-operculum and mid-ventral part. At this stage the pigmented eyes are visible through the chorion. In this condition, the egg is ready to hatch.

Oviposited eggs are often pierced and sucked by their adults, thus leaving only the shrivelled and transparent chorions. This phenomenon occurs even in the presence of abundant food, but is more frequently seen under the dry condition. Contrarily, Hill $(1957,1961)$ indicated that Anthocoris nemorum (Linné) and $A$. sarothamni Douglas et Scott sucked their eggs in spite of an abundance of moisture. In any case a long time exposure of ovipos- 
ited filter paper with the adult is harmful to the eggs. The author's experiment shows that the rate of hatching is very low from a filter paper which remained in the container with the adults for more than 48 hours. Though the ratio of pierced egg deposited on the other substrata was not observed in the present work, Hill (1965) indicated that the eggs of Anthocoris confusus (Reuter) laid on the filter paper were easier to be sucked by the adults than the eggs on plant material. The egg-piercing habit is more pronounced in $\mathrm{X}$. galactinus which prefers moist circumstance than L.beneficus. Therefore, it is presumed that the eggs may serve as somewhat suitable water supply for the adult bug under a certain parched condition. Under the favorable condition, the rate of hatching is apparently very high, being more than $95 \%$ While in some cases, a low percentage of hatchability was observed. As to the cause of low rate of hatching, the following three cases are considered, 1) dryness of oviposited material, 2) egg-piercing habit by adult and 3) age of female adult. The third case is discussed in the later part of this chapter.

\section{N ymph.}

The eclosion occurs mainly at 8-10 am in both species, and only a few instances were observed in the night. The average time taken for eclosion by L.beneficus and X. galactinus under $30^{\circ} \mathrm{C}$ condition were 9 and 7 minutes respectively. The process of eclosion is very similar in both species. Herewith is described the eclosion process of L.beneficus. Eclosion activity was at first begun with the vigorous movement of embryo. Through this movement the chorion which was imbedded into the filter paper became removable, resulting the position of egg vertical or perpendicular to the surface of paper. At this stage, the operculum still remained the same position, but after 4-5 min the nymph before hatching began slow bending or dorso-ventral levering movement and it dropped off suddenly, after then the embryo came to lie at an obtuse angle to the paper and began violent movement to liberate appendages from the chorion. After 2 minutes the antennae were extended, and it took only 30 seconds to stretch all the legs. The continuous muscular movement freed the abdomen from the chorion. The whole process of eclosion was accomplished by the nymphal bending forward and grasping the paper by the front legs and, only a few seconds were needed to complete the last stage of eclosion.

As many other species of Anthocorid bugs, five nymphal instars are recognized in both species. Under the condition of $30^{\circ} \mathrm{C}$ the total period from eclosion to adult ranged approximately from 17 to 22 days and 11 to 15 days in L. beneficus and X. galactinus respectively. In each test, complete records were made on 20-30 individuals to observe the duration of nymphal instars under various temperature conditions (Tables 8 \& 9).

It is evident that within the range of temperaturs tested the nymphal development becomes more speedy in warmer conditions. The acceleration 
Table 8. Duration of nymphal instars of Lyctocoris benejcus at different temperature conditions (in days).

\begin{tabular}{lcccccc}
\hline Temp & 1 & 2 & Instar & & \multicolumn{1}{c}{ Total } \\
$25^{\circ} \mathrm{C}$ & $2-2.3-4$ & $2-3.2-5$ & $4-4.8-8$ & $4-5.6-8$ & $5-6.9-8$ & $20-22.8-25$ \\
$30^{\circ} \mathrm{C}$ & $2-2.2-4$ & $2-2.6-4$ & $3-4.7-6$ & $4-5.1-7$ & $4-5.1-7$ & $17-18.7-22$ \\
$33^{\circ} \mathrm{C}$ & $2-2.2-4$ & $2-2.5-4$ & $3-4.1-6$ & $3-4.4-6$ & $4-4.7-7$ & $16-17.9-22$ \\
$\begin{array}{c}\text { Room temp } \\
\left(28-33^{\circ} \mathrm{C}\right)\end{array}$ & $2-2.4-4$ & $2-2.7-4$ & $3-4.3-6$ & $4-4.8-7$ & $4-5.2-8$ & $18-19.4-24$ \\
\hline
\end{tabular}

Table 9. Duration of nymphal instars of Xylocoris galactinus at different temperature condition (in days).

\begin{tabular}{ccccccc}
\hline Temp & \multicolumn{5}{c}{ Instar } & \multicolumn{2}{c}{ Total } \\
\cline { 2 - 5 } & 1 & 2 & 3 & 4 & 5 & \\
\cline { 3 - 5 } $25^{\circ} \mathrm{C}$ & $2-2.7-4$ & $\mathrm{Z}-3.0-5$ & $2-3.3-5$ & $2-3.7-5$ & $5-6.7-9$ & $17-19.4-22$ \\
$30^{\circ} \mathrm{C}$ & $1-1.8-3$ & $1-1.9-3$ & $2-2.6-4$ & $2-2.2-3$ & $3-4.5-7$ & $11-13.6-15$ \\
$33^{\circ} \mathrm{C}$ & $1-1.7-3$ & $1-1.7-3$ & $2-2.4-3$ & $2-2.13$ & $3-4.3-6$ & $11-12.4-14$ \\
$\begin{array}{c}\text { Room temp } \\
\left(28-33^{\circ} \mathrm{C}\right)\end{array}$ & $1-2.0-3$ & $1-2.2-3$ & $2-2.7-4$ & $2-2.4-4$ & $3-4.8-7$ & $12-14.1-16$ \\
\hline
\end{tabular}

of nymphal development under certain higher temperature conditions is generally known in many insects including another Anthocorid bug (Butler 1966). Among 5 stadia, the fifth stadium was the longest and the first and second stadia were the shortest in both species. Relative humidity ranging between 53-100 \% was not influential on the duration of nymphal period. Further, there was no significant difference between the rate of nymphal development of male and female individuals.

\section{A dult.}

1. Emergence. When a nymph accomplishes nymphal growth, emergence of both species takes place in the morning as indicated in Figs. 3 and 4.

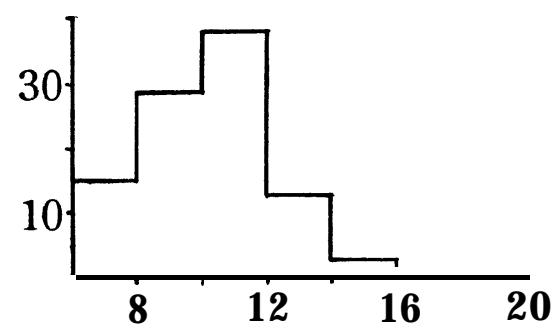

Fig. 3. Frequency distribution histogram of the time of emergence observed in Xylocoris galactinus. Abscissa : time in o'clock, Ordinate : Number of observations.

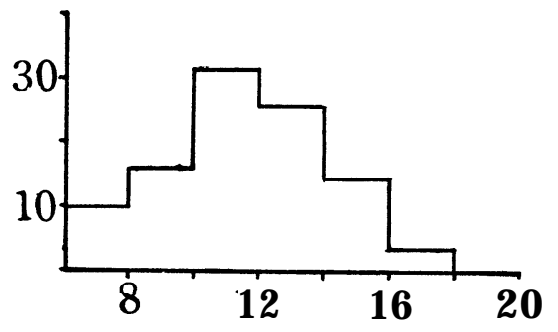

Fig. 4. Frequency distribution histogram of the time of emergence observed in Lyctocoris benejcus. Abscissa : time in o'clock, Ordinate : Number of observations. 
The body of newly emerged adult is milky pinkish in colour and the wings are whitish. In $\mathbf{L}$. beneficus, it took 15 minutes before the clavus starts to get its dark colour. Darkening of the eyes also took about the same minutes, Gradually, the pale pink colour of the adult changed to the full coloration 4 to 5 hours afer emergence. The process of colour change of newly emerged adult of $\mathrm{X}$. galactinus was similar to that of $\mathrm{L}$. beneficus, but it took only 100 to 120 minutes to accomplish the whole process pigmentation.

2. Copulation. If the male and female are placed together in the rearing tube, copulation or attempt to copulate may occur within a few seconds at any time of the day or night. Mating was even observed in the insect aspirator among the just collected individuals from the field. The pre-copulatory period of male adult in $\mathrm{X}$. galactinus was very short and mating behaviour occurred after several hours since the darkening of colour was finished, and that of $\mathbf{L}$. beneficus was somewhat similar to $\mathbf{X}$. galactinus. This fact nearly indicates that in the newly emerged male adult the reproductive organs already attained to maturity. Adult female of any age including mature and newly emerged pink coloured individuals may become the object of copulation for the male. The fertilized females very frequently refuse the males and struggle against the males vigorously. Virgin females, on the other hand, readily accept the males. The male mounts on the back of the female, keeping his body dorso-laterally to the body of female and to her right side. Male holds her with the help of numerous spines found on the inner margin of the fore tibiae. In this case, his three left legs are placed (1) on her pronotum, (2) at the basal portion of the hemielytron and (3) at the cuneus of the left hemielytron. Right fore-leg is lifted up while the right mid-leg is touching the substratum, thus supporting the weight of the male. During the course of copulation, the antennae of male are making back and forth movements. Those of the female are always stretched forward and very rarely touching the male antennae. The female remains motionless during the entire course of copulation, stretching her rostrum for ward. In a very few instances, copulating females were observed depressing her head and raising the tip of abdomen and walking with the mate on her back. The left ventro-lateral surface of the male's body was in contact with the right ventro-lateral surface of the female's body, thus allowing the insertion of the left paramere of the male to the female genital openning without any difficulty. The average time consumed for the copulation of $\mathrm{L}$. beneficus and $\mathrm{X}$. galactinus was 2.5 and 2.0 minutes respectively. One mating is seemed to be almost enough to supply sufficient spermatozoa to the female to lay fertilized eggs throughout her life.

3. Oviposition. The pre-oviposition period is very much variable depending upon the temperature conditions and the records of experimental data are indicated in Tables 12-17. It was 15.2, 7.3 and 6.9 days under $25^{\circ}, 30$ " and $33^{\circ} \mathrm{C}$ respectively in L. beneficus and $12.8,4.1$ and 3.8 days in $\mathrm{X}$. galactinus on 
an average. Within the range of such temperature conditions, relative humidity between 53-100\% did not give any influences upon the pre-oviposition period. If the temperature decreases during the earlier life of adult, the period may be prolonged. If a 2 day old female adult was placed to $25^{\circ} \mathrm{C}$ condition from $30^{\circ} \mathrm{C}$, her pre-oviposition period was prolonged to 17.6 and 15.3 days in $L$. beneficus and $X$. galactinus respectively. This data were apparently longer than the period shown by the adult reared under the constant temperature condition. While the inverse transfer of adults, namely low to high, did not shorten the pre-oviposition period.

The oviposition is conducted at any time of the day or night, although somewhat more eggs are produced during the daytime. But no significant diurnal ovipositional rhythm is observed.

When the female is ready to oviposit, she moves slowly on the substratum examining it every few seconds with the tip of her rostrum while she is vibrating her antennae rapidly. Quite suddenly, the female stands still, raises up her body high and bends the tip of her abdomen so that it touches the surface of paper. Then, her ovipositor is stretched vertically to be inserted in the substratum. When the insertion of ovipositor is finished, the female takes the normal position with the antennae stretched forward, and with the abdomen showing rhythmical contracting movements. By these movements, the ovipositor is deeply inserted into the substratum. The final passage of the egg into the substratum is carried out without any perceptible extra effort and the ovipositor is at once removed. The average times taken for oviposition process in $L$. beneficus and X. galactinus were 80 and 50 seconds respectively. The eggs are not laid aggressively but placed singly.

It is almost evident that especially in the field the barn straw is the most important oviposition substratum. Under the laboratory condition, both species actively deposited eggs on the moist straw. In addition to straw, the cherry twig, moist filter paper, moist vermiculite and slightly molded cracked corn are excellent substrata for the oviposition of both species. A few eggs are also deposited on the moist wood chops (Acacia sp.). As the optimal condition for the oviposition substratum, suitable moisture and softness of materials are demanded. Although Hill (1957, 1961) and Tawfik and Nagui (1965) observed the oviposition of other Anthocorid bugs on the wall of rearing glass tube, no egg was observed on the wall of a glass tube in the present experiment.

To compare the suitability of these materials as the ovipositional substratum, 20 adult females were kept in the $100 \mathrm{ml}$ beaker with one of these materials and, thus six beakers of this kind were prepared and the number of newly hatched nymphs were counted after several days in each beaker. As the counting of oviposited eggs on such materials as vermiculite, corn, straw and wood chop was actually difficult, the number of hatched nymphs 
was taken as the index of oviposition suitability and preference. Therefore, in this test, it was possible to compare the suitability both for oviposition and egg development at the same time. This work was conducted for 5 days, renewing the substratum every day (Table 10). In another series of test, the combination of more than 2 kinds of oviposition substrata were used in each beaker containing 20 adult females and examined their oviposition preference. In this connection, it must be noted that the vermiculite used contained some water (vermiculite : water=100: $15 \mathrm{w} / \mathrm{w})($ Table 11).

Table 10. Number of newly hatched nymphs from the various ovipositional substrata per day, each substratum provided with 20 adult females of Lyctocoris beneficus and Xylocoris galactinus at the beginning of the experiment.

\begin{tabular}{lcc}
\hline \multicolumn{1}{c}{ Substratum } & L. beneficus & X. galactinus \\
Moist straw & 17.2 & 21.0 \\
Moist filter paper & 24.4 & 25.8 \\
Moist vermiculite & 18.5 & 24.3 \\
Cherry twig & 32.0 & 21.7 \\
Molded cracked corn & 21.6 & 27.5 \\
Wood chop (Acacia sp.) & 5.1 & 8.3
\end{tabular}

Table 11. Number of newly hatched nymphs from the various ovipositional substrata per day, each combination provided with 20 adult females of Lyctocoris beneficus and Xylocoris galactinus at the beginning of the experiment.

\begin{tabular}{|c|c|c|c|}
\hline \multirow{2}{*}{$\begin{array}{l}\text { Combi- } \\
\text { nation }\end{array}$} & \multirow{2}{*}{ Substrataum } & \multicolumn{2}{|c|}{ No. of nymphs hatched } \\
\hline & & L. beneficus & X. galactinus \\
\hline & Straw & 8.2 & 6.8 \\
\hline \multirow[t]{4}{*}{ A } & Filter paper & 9.4 & 9.4 \\
\hline & Cherry twig & 18.2 & 13.2 \\
\hline & Cracked corn & 10.6 & 14.6 \\
\hline & Straw & 8.4 & 4.4 \\
\hline \multirow[t]{4}{*}{ B } & Filter paper & 11.6 & 8.2 \\
\hline & Cherry twig & 14.4 & 9.8 \\
\hline & Vermiculite & 5.0 & 10.4 \\
\hline & Straw & 8.2 & 5.4 \\
\hline \multirow[t]{3}{*}{ C } & Filter paper & 14.6 & 13.6 \\
\hline & Cherry twig & 16.4 & 6.6 \\
\hline & Wood chop & 1.8 & 1.2 \\
\hline
\end{tabular}


As the data of Tables 10 and 11 show, cherry twig was the most preferred oviposition substratum for L.beneficus. Filter paper and molded cracked corn were also an excellent ones for this species, but dry cracked corn was not suitable for the oviposition of both species. In the case of $X$. galactinus, majority of newly hatched nymphs were from filter paper, molded cracked corn and vermiculite. Wood chop was the worst in both species. Actually the oviposition was influenced by the kind of substratum. The influence of substrata on the oviposition behaviour was also observed in some groups of insects by Chalfant and Mitchell (1967). In conclusion, the following order may be established from Tables 10 and 11 on the suitability and preference of oviposition in each species.

L. beneficus. cherry twig $>$ cracked corn $>$ filter paper $>$ straw $>$ vermiculite $>$ wood chop.

$X$. galactinus. cracked corn $>$ vermiculite $>$ filter paper $>$ cherry twig $>$ straw $>$ wood chop.

The oviposition preference between the two species is apparently variable not only with the kind of substratum but also with the condition of substratum, especially relating to its water content. In any cases, adults avoid to deposite their eggs on the parched or extremely moist substrata.

The oviposition period, number of eggs per female and longevity were examined by the use of fertile females which were kept separately in a $9 \times 2.5 \mathrm{~cm}$ (length $\mathrm{x}$ diameter) flat-bottomed corked glass tube. And a sheet of filter paper cut in $1 \times 4 \mathrm{~cm}$ square was provided in the tube for the supply of water as well as oviposition substratum. Adult females readily accepted the moist paper for oviposition, and the larvae of red flour beetle (Tribolium castaneum (Herbst)) were supplied as food. The tubes were examined daily. The filter papers were renewed and the eggs deposited on the paper were counted daily. The tests were carried out under $25^{\circ}, 30^{\prime}$ and $33^{\circ} \mathrm{C}$ temperature conditions. The detailed results are given in Tables 1217 and the summary is shown in Tables 18 \& 19.

It is evident that the individual variation is extremely large both in longevity and egg-production activity. Actually these are easily influenced by some factors as nutritional condition, population density, etc., and the affects of these factors are discussd in the later chapters. So far as the data in these tables are concerned, the longevity of adult female was greatly affected by temperature. In L.beneficus, it showed 39.2, 31.0 and 24.5 days on an average under the respective temperature condition. When the adults were kept under $25^{\circ} \mathrm{C}$ condition, the minimum longevity was 23 days while the maximum one was 53 days. The average longevity of $X$. galactinus was $36.9,26.4$ and 22.6 days for $25^{\circ} \mathrm{C}, 30^{\circ} \mathrm{C}$ and $33^{\circ} \mathrm{C}$ conditions respectively, and it was evidently shorter than that of $\boldsymbol{L}$. beneficus. In both species, high temperature gave bad effect on the longevity as well as on the egg- 
Table 13. Length of life ana egg-laying activity of Lyctocoris beneficus under $25^{\circ} \mathrm{C}$ condition.

\begin{tabular}{|c|c|c|c|c|c|c|c|c|c|c|c|c|c|}
\hline \multirow[t]{2}{*}{$\begin{array}{c}\text { Female } \\
\text { No. }\end{array}$} & \multirow{2}{*}{$\begin{array}{c}\text { Pre- } \\
\text { oviposition } \\
\text { period(day) }\end{array}$} & \multirow{2}{*}{$\begin{array}{l}\text { Oviposition } \\
\text { period } \\
\text { (day) }\end{array}$} & \multirow{2}{*}{$\begin{array}{c}\text { Post- } \\
\text { oviposition } \\
\text { period(day) }\end{array}$} & \multirow{2}{*}{$\begin{array}{c}\text { Longevity } \\
\text { (day) }\end{array}$} & \multicolumn{6}{|c|}{$\begin{array}{l}\text { No. of eggs Jaid per week } \\
\text { (from beginning of oviposition) }\end{array}$} & \multirow{2}{*}{$\begin{array}{c}\text { Total } \\
\text { of } \\
\text { eggs(A) }\end{array}$} & \multirow{2}{*}{$\begin{array}{l}\text { Actual } \\
\text { days of ovi- } \\
\text { position(B) }\end{array}$} & \multirow{2}{*}{$\begin{array}{l}\text { Eggs } \\
\text { perday } \\
\text { (A/B ) }\end{array}$} \\
\hline & & & & & 1 & 2 & 3 & 4 & 5 & 6 & & & \\
\hline $\begin{array}{ll}2 & \\
3 & \end{array}$ & 144 & 23 & 9 & 27 & 18 & 18 & 18 & 8 & $\overline{0}$ & $\begin{array}{l}- \\
-\end{array}$ & 89 & 8 & 7.45 .6 \\
\hline $\begin{array}{l}4 \\
5\end{array}$ & $\begin{array}{l}13 \\
16\end{array}$ & $\begin{array}{l}11 \\
33\end{array}$ & $\begin{array}{l}8 \\
0\end{array}$ & $\begin{array}{l}32 \\
49\end{array}$ & $\begin{array}{l}16 \\
11\end{array}$ & $\begin{array}{l}4 \\
8 \\
9\end{array}$ & $\begin{array}{l}\overline{0} \\
7\end{array}$ & $\begin{array}{l}- \\
- \\
0\end{array}$ & $\overline{-}$ & $\begin{array}{l}- \\
-\end{array}$ & $\begin{array}{l}28 \\
24 \\
32\end{array}$ & $\begin{array}{l}4 \\
3 \\
6\end{array}$ & $\begin{array}{l}7.0 \\
8.0 \\
6.3\end{array}$ \\
\hline $\begin{array}{r}6 \\
8 \\
9 \\
10\end{array}$ & $\begin{array}{l}15 \\
15 \\
16 \\
14\end{array}$ & $\begin{array}{l}38 \\
17 \\
16 \\
29\end{array}$ & $\begin{array}{r}\text { P } \\
21 \\
0 \\
3\end{array}$ & $\begin{array}{l}41 \\
53 \\
32 \\
46\end{array}$ & $\begin{array}{l}11 \\
22 \\
18\end{array}$ & $\begin{array}{r}20 \\
3 \\
21 \\
17 \\
21\end{array}$ & $\begin{array}{r}4 \\
8 \\
16\end{array}$ & $\begin{array}{l}8 \\
0 \\
- \\
5\end{array}$ & $\begin{array}{l}2 \\
0 \\
- \\
8\end{array}$ & $\begin{array}{l}= \\
0 \\
-\end{array}$ & $\begin{array}{l}58 \\
14 \\
47 \\
43 \\
62\end{array}$ & $\begin{array}{l}8 \\
2 \\
6 \\
5 \\
8\end{array}$ & $\begin{array}{l}7.3 \\
7.0 \\
7.8 \\
8.6 \\
7.8\end{array}$ \\
\hline Avg & 14.8 & 20.1 & 4.3 & 39.2 & 15.8 & 13.8 & 7.1 & 2.4 & 1.5 & 0.0 & 40.6 & 5.7 & 7.3 \\
\hline
\end{tabular}

Table 13. Length of life and egg-laying activity of Lyctocoris beneficus under $30^{\circ} \mathrm{C}$ condition.

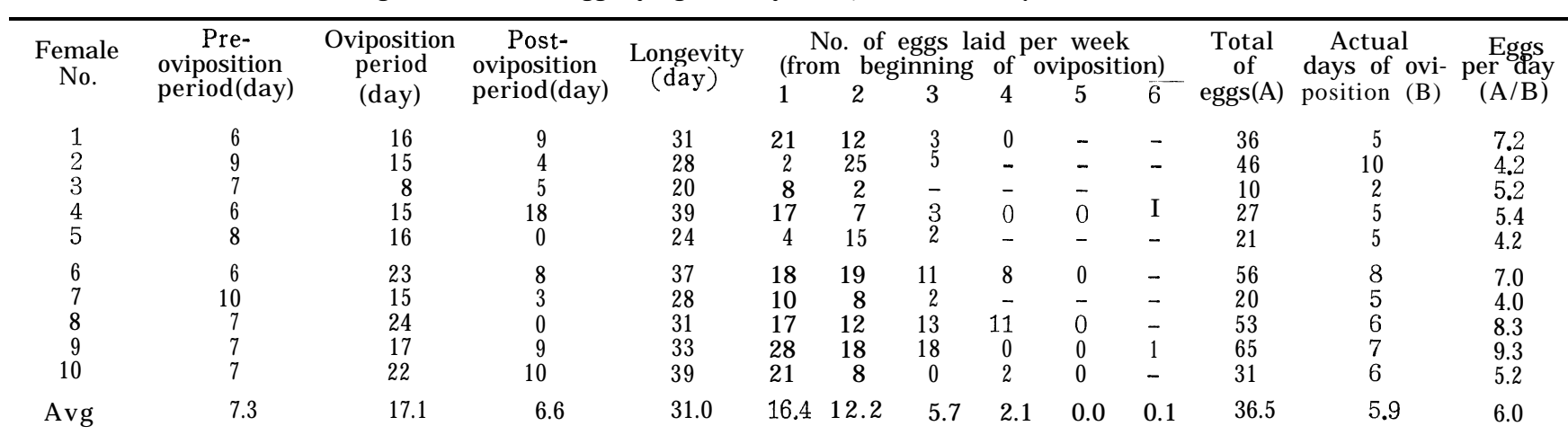


Table 14. Length of life and egg-laying activity of Lyctocoris beneficus under $33^{\circ} \mathrm{C}$ condition.

\begin{tabular}{|c|c|c|c|c|c|c|c|c|c|c|c|c|c|c|}
\hline \multirow{2}{*}{$\begin{array}{c}\text { Female } \\
\text { No. }\end{array}$} & \multirow{2}{*}{$\begin{array}{c}\text { Pre- } \\
\text { oviposition } \\
\text { period(day) }\end{array}$} & \multirow{2}{*}{$\begin{array}{l}\text { Oviposition } \\
\text { period } \\
\text { (day) }\end{array}$} & \multirow{2}{*}{$\begin{array}{c}\text { Post- } \\
\text { oviposition } \\
\text { period(day) }\end{array}$} & \multirow{2}{*}{$\begin{array}{l}\text { Longevity } \\
\text { (day) }\end{array}$} & \multicolumn{3}{|c|}{$\begin{array}{c}\text { No. of eggs } \\
\text { (from beginning }\end{array}$} & \multirow{2}{*}{$\begin{array}{r}\text { laid } \\
\text { of } \\
4\end{array}$} & \multicolumn{2}{|c|}{$\begin{array}{l}\text { per week } \\
\text { oviposition) }\end{array}$} & \multirow{2}{*}{$\begin{array}{r}\text { Total } \\
\text { of } \\
\text { eggs(A) }\end{array}$} & \multirow{2}{*}{\multicolumn{2}{|c|}{$\begin{array}{l}\text { Actual } \\
\text { days of ovi- } \\
\text { position (B) }\end{array}$}} & \multirow{2}{*}{$\begin{array}{l}\text { Eggs } \\
\text { per. day } \\
\text { (A/B) }\end{array}$} \\
\hline & & & & & 1 & 2 & 3 & & 5 & 6 & & & & \\
\hline $\begin{array}{l}1 \\
2 \\
3 \\
4 \\
5\end{array}$ & $\begin{array}{l}7 \\
6 \\
8 \\
7 \\
6\end{array}$ & $\begin{array}{r}13 \\
15 \\
12 \\
29 \\
1\end{array}$ & $\begin{array}{r}0 \\
2 \\
17 \\
0 \\
11\end{array}$ & $\begin{array}{l}20 \\
29 \\
25 \\
36 \\
18\end{array}$ & $\begin{array}{r}12 \\
13 \\
9 \\
24 \\
11\end{array}$ & $\begin{array}{r}8 \\
16 \\
7 \\
15 \\
0\end{array}$ & $\begin{array}{l}- \\
8 \\
0 \\
2 \\
-\end{array}$ & $\begin{array}{l}-\overline{0} \\
- \\
3 \\
-\end{array}$ & $\begin{array}{l}\mathrm{I} \\
\overline{7} \\
-\end{array}$ & $\begin{array}{l}I \\
- \\
-\end{array}$ & $\begin{array}{l}20 \\
37 \\
16 \\
51 \\
11\end{array}$ & $\begin{array}{l}5 \\
4 \\
4 \\
9 \\
1\end{array}$ & & $\begin{array}{r}4.0 \\
9.3 \\
4.0 \\
5.7 \\
11.0\end{array}$ \\
\hline $\begin{array}{r}6 \\
7 \\
8 \\
9 \\
10\end{array}$ & $\begin{array}{r}6 \\
10 \\
7 \\
6 \\
6\end{array}$ & $\begin{array}{r}9 \\
12 \\
17 \\
18 \\
18\end{array}$ & $\begin{array}{l}2 \\
1 \\
3 \\
2 \\
0\end{array}$ & $\begin{array}{l}17 \\
23 \\
27 \\
26 \\
24\end{array}$ & $\begin{array}{r}31 \\
2 \\
13 \\
21 \\
17\end{array}$ & $\begin{array}{r}4 \\
7 \\
8 \\
12 \\
6\end{array}$ & $\begin{array}{l}- \\
- \\
3 \\
4 \\
2\end{array}$ & $\begin{array}{l}- \\
- \\
- \\
-\end{array}$ & $\begin{array}{l}- \\
- \\
- \\
-\end{array}$ & $\begin{array}{l}- \\
- \\
- \\
-\end{array}$ & $\begin{array}{r}35 \\
9 \\
24 \\
37 \\
25\end{array}$ & $\begin{array}{l}7 \\
3 \\
5 \\
6 \\
5\end{array}$ & & $\begin{array}{l}5.0 \\
3.0 \\
4.8 \\
6.2 \\
5.0\end{array}$ \\
\hline Avg & 6.9 & 14.4 & 3.8 & 24.5 & 15.3 & 8.3 & 1.9 & 0.3 & 0.7 & - & 26.5 & 4.9 & & 5.8 \\
\hline
\end{tabular}

Table 15. Length of life and egg-laying activity of Xylocoris galactinus under $25^{\circ} \mathrm{C}$ condition.

\begin{tabular}{|c|c|c|c|c|c|c|c|c|c|c|c|c|c|}
\hline \multirow{2}{*}{$\begin{array}{c}\text { Female } \\
\text { No. }\end{array}$} & \multirow{2}{*}{$\begin{array}{c}\text { Pre- } \\
\text { oviposition } \\
\operatorname{period}(\text { day) }\end{array}$} & \multirow{2}{*}{$\begin{array}{l}\text { Oviposition } \\
\text { period } \\
\text { (day) }\end{array}$} & \multirow{2}{*}{$\begin{array}{c}\text { Post- } \\
\text { oviposition } \\
\text { period(day) }\end{array}$} & \multirow{2}{*}{$\begin{array}{l}\text { Longevity } \\
\text { (day) }\end{array}$} & \multicolumn{3}{|c|}{$\begin{array}{c}\text { No. of eggs } \\
\text { (from beginning }\end{array}$} & \multirow[t]{2}{*}{ laid $\mathrm{p}$} & \multicolumn{2}{|c|}{$\begin{array}{l}\text { per week } \\
\text { oviposition) }\end{array}$} & \multirow{2}{*}{$\begin{array}{c}\text { Total } \\
\text { of } \\
\text { eggs (A) }\end{array}$} & \multirow{2}{*}{$\begin{array}{l}\text { Actual } \\
\text { days of ovi- } \\
\text { position (B) }\end{array}$} & \multirow{2}{*}{$\begin{array}{l}\text { Eggs } \\
\text { per day } \\
(\mathrm{A} / \mathrm{B})\end{array}$} \\
\hline & & & & & 12 & 3 & 4 & & 5 & 6 & & & \\
\hline $\begin{array}{l}1 \\
2 \\
3 \\
4 \\
5\end{array}$ & $\begin{array}{l}14 \\
15 \\
14 \\
10 \\
10\end{array}$ & $\begin{array}{l}22 \\
16 \\
22 \\
37 \\
36\end{array}$ & $\begin{array}{l}1 \\
0 \\
1 \\
2 \\
2\end{array}$ & $\begin{array}{l}37 \\
31 \\
39 \\
49 \\
48\end{array}$ & $\begin{array}{l}21 \\
18 \\
24 \\
16 \\
14\end{array}$ & $\begin{array}{r}13 \\
4 \\
21 \\
14 \\
23\end{array}$ & $\begin{array}{r}6 \\
5 \\
18 \\
15 \\
16\end{array}$ & $\begin{array}{r}2 \\
- \\
12 \\
16 \\
8\end{array}$ & $\begin{array}{r}- \\
\overline{12} \\
8\end{array}$ & $\begin{array}{l}- \\
\overline{-} \\
\overline{7} \\
1\end{array}$ & $\begin{array}{l}42 \\
27 \\
75 \\
80 \\
70\end{array}$ & $\begin{array}{r}8 \\
5 \\
12 \\
9 \\
13\end{array}$ & $\begin{array}{l}5.3 \\
5.4 \\
6.3 \\
8.7 \\
5.4\end{array}$ \\
\hline $\begin{array}{r}6 \\
7 \\
8 \\
9 \\
10\end{array}$ & $\begin{array}{l}11 \\
13 \\
13 \\
14 \\
14\end{array}$ & $\begin{array}{l}22 \\
16 \\
22 \\
13 \\
17\end{array}$ & $\begin{array}{l}2 \\
3 \\
4 \\
0 \\
1\end{array}$ & $\begin{array}{l}35 \\
32 \\
39 \\
27 \\
32\end{array}$ & $\begin{array}{r}6 \\
19 \\
8 \\
6 \\
11\end{array}$ & $\begin{array}{r}14 \\
16 \\
9 \\
19 \\
20\end{array}$ & $\begin{array}{r}3 \\
14 \\
3 \\
\overline{1}\end{array}$ & $\begin{array}{l}4 \\
- \\
2 \\
- \\
-\end{array}$ & $\begin{array}{l}- \\
- \\
- \\
-\end{array}$ & $\begin{array}{l}- \\
- \\
- \\
- \\
-\end{array}$ & $\begin{array}{l}27 \\
49 \\
22 \\
25 \\
47\end{array}$ & $\begin{array}{l}6 \\
7 \\
5 \\
3 \\
6\end{array}$ & $\begin{array}{l}4.5 \\
7.0 \\
4.4 \\
8.3 \\
7.8\end{array}$ \\
\hline Avg & 12.8 & 22.3 & 1.6 & 36.9 & 18.8 & 16.9 & 7.1 & 2.2 & 2.0 & 0.8 & 46.4 & 7.4 & 6.3 \\
\hline
\end{tabular}


Table 16. Length of life and egg-laying activity of Xylocoris galactinus under $30^{\circ} \mathrm{C}$ condition.

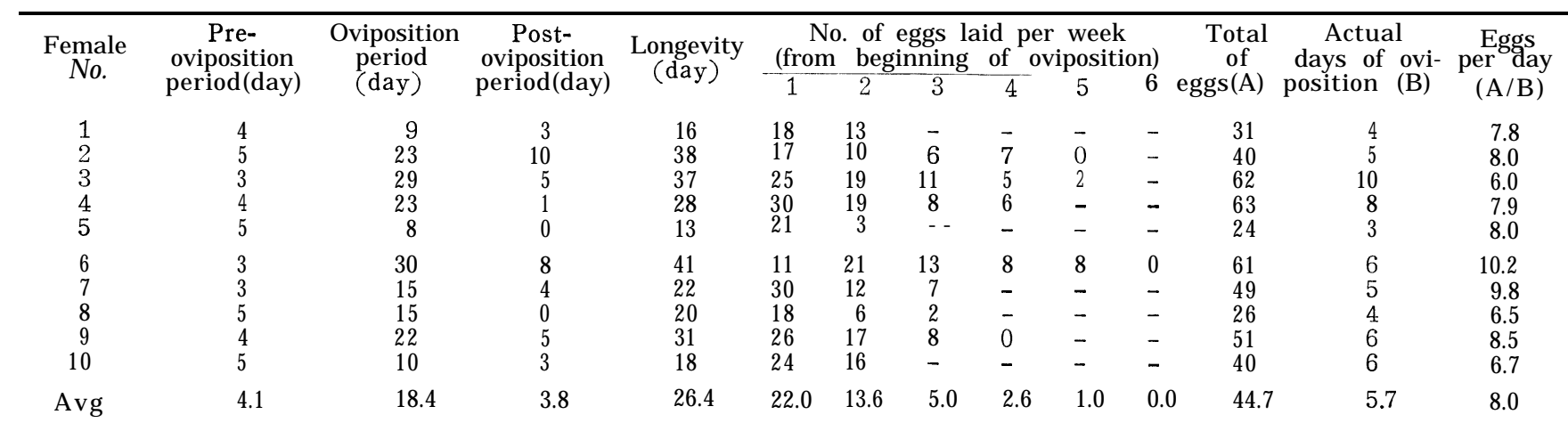

Table 17. Length of life and egg-laying activity of Xylocoris galactinus under $33^{\circ} \mathrm{C}$ condition.

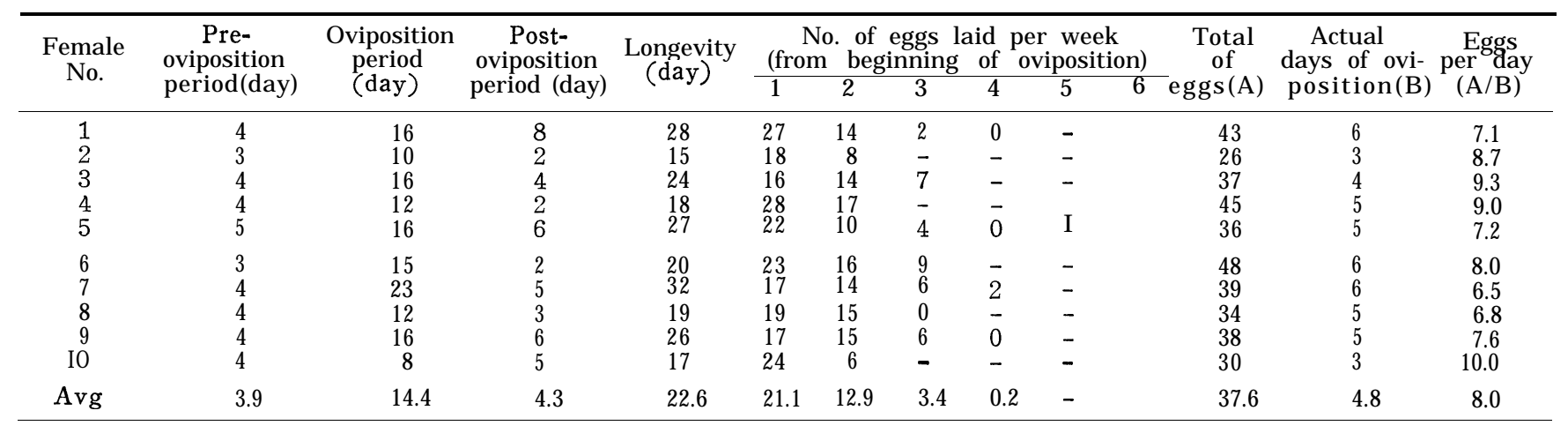


Table 18. Oviposition of adult Lyctocoris beneficus under various temperature conditions.

\begin{tabular}{|c|c|c|c|c|c|c|c|c|c|c|}
\hline \multirow{2}{*}{ Temp. } & \multirow{2}{*}{$\begin{array}{l}\text { Oviposition } \\
\text { period } \\
\text { (day) }\end{array}$} & \multicolumn{6}{|c|}{ No. of eggs laid per week* } & \multirow{2}{*}{$\begin{array}{c}\text { Eggs per } \\
\text { female } \\
\text { (A) }\end{array}$} & \multirow{2}{*}{$\begin{array}{l}\text { Days of } \\
\text { oviposition } \\
\text { (B) }\end{array}$} & \multirow{2}{*}{$\begin{array}{l}\text { No. of } \\
\text { eggs per day } \\
(A / B)\end{array}$} \\
\hline & & 1 & 2 & 3 & 4 & 5 & 6 & & & \\
\hline $25^{\circ} \mathrm{C}$ & 20.1 & 15.8 & 13.8 & 7.1 & 2.4 & 1. 5 & 0.0 & 40.6 & 5.7 & 7.3 \\
\hline $30^{\circ} \mathrm{C}$ & 17.1 & 16.4 & 12.2 & 5.7 & 2.1 & 0.0 & 0.1 & 36.5 & 5.9 & 6.0 \\
\hline $33^{\circ} \mathrm{C}$ & 14.4 & 15. 3 & 8. 3 & 1.9 & 0.3 & 0.7 & 0.0 & 26.5 & 4.9 & 5.8 \\
\hline
\end{tabular}

Table 19. Oviposition of adult Xylocoris galactinus under various temperature conditions.

\begin{tabular}{|c|c|c|c|c|c|c|c|c|c|c|}
\hline \multirow{2}{*}{ Temp. } & \multirow{2}{*}{$\begin{array}{l}\text { Oviposition } \\
\text { period } \\
\text { (day) }\end{array}$} & \multicolumn{6}{|c|}{ No. of eggs laid per week* } & \multirow{2}{*}{$\begin{array}{l}\text { Eggs per } \\
\text { female } \\
\text { (A) }\end{array}$} & \multirow{2}{*}{$\begin{array}{l}\text { Days of } \\
\text { oviposition } \\
\text { (B) }\end{array}$} & \multirow{2}{*}{$\begin{array}{l}\text { No. of } \\
\text { eggs per day } \\
\text { (A/B) }\end{array}$} \\
\hline & & 1 & 2 & 3 & 4 & 5 & 6 & & & \\
\hline $25^{\circ} \mathrm{C}$ & 22.3 & 18.8 & 16. 9 & 7.1 & 2. 2 & 0.7 & 0.7 & 46.4 & 7.4 & 6.3 \\
\hline $30^{\circ} \mathrm{C}$ & 18.4 & 22.0 & 13.6 & 5.5 & 2.4 & 1.0 & 0.2 & 44.7 & 5.7 & 7.9 \\
\hline $33^{\circ} \mathrm{C}$ & 14.4 & 21.1 & 12.9 & 3.4 & 0.2 & 0.0 & 0.0 & 37.6 & 4.8 & 8.0 \\
\hline
\end{tabular}


production capacity. However, shorter pre-oviposition period was observed in the $33^{\circ} \mathrm{C}$ reared groups, and the production of egg was clearly decreased. The growth was postponed in the individuals which were reared under the condition of low temperature, but the number of eggs oviposited per female was the highest in these individuals. The number of eggs laid by $\boldsymbol{L}$. beneficus and $X$.galactinus were 40.6 and 46.4 respectively, making an apparent contrast with the fewer number 26.5 and 37.6 for the respective species which were reared under the condition of $33^{\circ} \mathrm{C}$. The post-oviposition period was longer in the groups which were reared under the higher temperature condition. Though not shown in the Tables, the longest record of post-oviposition period were 36 days in $L$. beneficus and 23 days in $X$. galactinus, and these records were obtained when the adults were kept under the condition of $25^{\circ} \mathrm{C}$ condition.

The longevity of adult male was given in Table 20, and it seems somewhat shorter than that of the female in both species.

Table 20. Longevity (min-avg-max) of male adult of Lyctocoris beneficus and $X y$ locoris galactinus at different temperature conditions (in days).

\begin{tabular}{ccc}
\hline Temperature & L. beneficus & $X$. galactinus \\
$25^{\circ} \mathrm{C}$ & $18-33.0-48$ & $13-29.6-45$ \\
$30^{\circ} \mathrm{C}$ & $15-23.5-42$ & $11-21.2-38$ \\
$33^{\circ} \mathrm{C}$ & $\mathrm{U}-23.3-39$ & $12-20.5-36$
\end{tabular}

High temperature over $33^{\circ} \mathrm{C}$ was not preferable for both species, and the bad effect of high temperature was more evident in $L$. beneficus. It seems that $X$. galactinus is more adapted to high temperature than $\boldsymbol{L}$. beneficus. This suggestion was also proved by the cold-hardiness test of these bugs as mentioned later.

\section{Effect of maternal age on the vitality of eggs.}

It is well-known that egg production of various insects may be greatly affected by environmental conditions and the past history of the mother. A considerable amount of literature on the influence of parental age has been accumulated for some groups of organisms by Strong (1954), and the studies in this field were conducted on some groups of insects (Durrant 1955, Sang 1956, Richard and Kolderie 1957). The author investigated the effect of parental age on the vitality of offspring in both species. For this purpose, 20 couples of adults which were emerged on the same day were kept in $9 \times 6 \mathrm{~cm}$ petri-dish (diameter $\mathrm{x}$ height), and the eggs deposited on the moist filter paper were isolated from the adult containers every day. The vitality of offspring was measured by the rate of hatching, length of nymphal stage, 
percent emergence and the body weight of new adult (Tables $21 \& 22$ ). As discussed in the later chapter, the length of nymphal stage, percent emergence, and body weight were apparently influenced by the number of rearing insects per unit space. But the effect of population density on these factors was not considered in this work. The work was carried out under the room temperature condition of $28-33^{\circ} \mathrm{C}$.

Table 21. The rate of hatching and the nymphal development of Lyctocoris beneficus in relation to parental age.

\begin{tabular}{|c|c|c|c|c|c|c|}
\hline \multirow{2}{*}{$\begin{array}{l}\text { Parental } \\
\text { age } \\
\text { (in weeks) }\end{array}$} & \multirow{2}{*}{$\begin{array}{l}\text { No. of } \\
\text { eggs } \\
\text { laid }\end{array}$} & \multirow{2}{*}{$\begin{array}{c}\text { Rate of } \\
\text { hatching } \\
(\%)\end{array}$} & \multirow{2}{*}{$\begin{array}{l}\text { Nymphal } \\
\text { stage } \\
\text { (in days) }\end{array}$} & \multirow{2}{*}{$\begin{array}{l}\text { Percent } \\
\text { emergence } \\
\text { (\%) }\end{array}$} & \multicolumn{2}{|c|}{$\begin{array}{c}\text { Weight of } \\
\text { new adult }(\mathrm{mg})\end{array}$} \\
\hline & & & & & $\sigma^{\lambda}$ & o \\
\hline 1 & 12 & 75.0 & 20.5 & 77.8 & 2.2 & 2.3 \\
\hline 2 & 343 & 92.7 & 19.2 & 85.5 & 2.4 & 2.3 \\
\hline 3 & 286 & 74.5 & 19.3 & 86.0 & 2.4 & 2.4 \\
\hline 4 & 139 & 62.6 & 21.7 & 60.9 & 2.3 & 2.4 \\
\hline 5 & 55 & 43.6 & 22.5 & 58.3 & 2.3 & 2.4 \\
\hline 6 & 27 & 44.4 & 23.8 & 50.0 & 2.3 & 2.3 \\
\hline
\end{tabular}

Table 22. The rate of hatching and the nymphal development of Xylocoris galactinus in relation to parental age,

\begin{tabular}{|c|c|c|c|c|c|c|}
\hline \multirow{2}{*}{$\begin{array}{c}\text { Parental } \\
\text { age } \\
\text { (in weeks) }\end{array}$} & \multirow{2}{*}{$\begin{array}{l}\text { No. of } \\
\text { eggs } \\
\text { laid }\end{array}$} & \multirow{2}{*}{$\begin{array}{l}\text { Rate of } \\
\text { hatching } \\
(\%)\end{array}$} & \multirow{2}{*}{$\begin{array}{l}\text { Nymphal } \\
\text { stage } \\
\text { (in days) }\end{array}$} & \multirow{2}{*}{$\begin{array}{l}\text { Percent } \\
\text { emergence } \\
\text { (\%) }\end{array}$} & \multicolumn{2}{|c|}{$\begin{array}{c}\text { Weight of } \\
\text { new adult (mg) }\end{array}$} \\
\hline & & & & & $\sigma^{\lambda}$ & 우 \\
\hline 1 & 103 & 84.5 & 13.8 & 62.1 & 1.3 & 1.3 \\
\hline 2 & 421 & 74.6 & 13.4 & 83.8 & 1.3 & 1.4 \\
\hline 3 & 336 & 83.6 & 13.2 & 81.9 & 1.3 & 1.4 \\
\hline 4 & 37 & 35.1 & 14.8 & 46.2 & 1.2 & 1.3 \\
\hline
\end{tabular}

As seen in Tables 21 and 22, both L.beneficus and X.galactinus showed the same tendency as to the effect of maternal age. The egg production was low in the first week especially in L.beneficus. It was no doubt due to the fact that most of the adults were still in the pre-oviposition period in this week. The highest percentage of egg-hatching and adult emergence were obtained from the offspring produced by the second and third week old parents. Also the shortening of the duration of nymphal stage was observed in such offsprings. The off spring production was suddenly decreased in the four week old parents, being about half and one third of the younger stage parents in L.beneficus and $X$. galactinus respectively. And the vitality of offspring produced by the adults of age later than the fourth week was clearly inferior to that of the younger individuals. No correlation was 
seen between the body weight of newly emerged and older adults.

In the laboratory condition under the constant temperature of $30^{\circ} \mathrm{C}$, about 54 days are necessary to complete one generation in the case of $L$. beneficus, while 43 days are needed in X.galactinus. On the other hand, the duration from "egg to egg" takes only about 31 days in the former and $\mathbf{2 1}$ days in the latter species. It is supposed that actually under the optimal artificial condition, both species may have more than 10 generations a year.

\section{Field observations}

Field observations on Lyctocoris beneficus (Hiura) and Xylocoris galactinus (Fieber) were mainly conducted on the giant straw piles at Saga Paper Board Co., under the various conditions of straws which were transported to the stock yard of the company. Life history in natural condition was also observed at the artificial small straw heap which was piled up in the campus of Kyushu University.

In the investigation at Saga both species were not collected in the months of January, February and March, while from the end of April, small numbers of adults of $X$.galactinus began to appear, and the adults became very abundant in the middle of May. Towards the end of this month, large numbers of both adults and various stages of nymphs were observed, and the abundance of these individuals remained through June. The spring emergence of $L$. beneficus was about 2-3 weeks later than that of X.galactinus. At the beginning of July, the population of both species decreased suddenly from the outer part of straw piles, and the low densities of the bugs were maintained till the middle of August. This is probably due to the bugs avoiding the high temperature of summer and emigrate deeply into the interior part of the straw pile, and this phenomenon may be caused owing to the decrease of absolute population by summer heat. This was proved by the fact that in this season many individuals of both species were found in the straw transported from the farmer's stock yard or in newly harvested paddy straws.

During September through October, various stages of both species reappeared in the straw piles. In this season both adults and various stage nymphs of L. beneficus were more abundant as compared with the spring emergence, while the population of X.galactinus nymphs decreased. To the end of October the nymphs of the latter species were scarcely found. In November, both species almost disappeared in the straw piles, but some were still collected in the straws just transported from the farmer's barn. The materials collected in this season were almost composed of adults of both species. This fact suggests that when the climate becomes cooler, they stop oviposition, and overwinter in the adult stage. The decrease of population in the giant piles is rather reasonally explair. ad by the fact that 
the bug emigrates into the internal part of the piles, because the low temperature in November is not enough to kill the bug (cf. Chap. 13).

The seasonal variation of the number of both sexes in field collected adults is given in Table 23. From this table it is proved that the sex ratio $\left(\frac{p}{0+q}\right)$ in the field condition remains nearly 0.5 through May to November.

Table 23. The seasonal variation of the number of both sexes in field collected Lyctocoris beneficus and Xylocoris galactinus ( $\overbrace{}^{-1}$ : 우).

\begin{tabular}{|c|c|c|c|}
\hline & & $L$. beneficus & $X$. galactinus \\
\hline April & $\begin{array}{l}\text { B. } \\
\text { M. } \\
\text { E. }\end{array}$ & $\begin{array}{l}- \\
-\end{array}$ & $\begin{array}{l}- \\
13: 16(7)\end{array}$ \\
\hline May & $\begin{array}{l}\text { B. } \\
\text { M. } \\
\text { E. }\end{array}$ & $\begin{array}{r}4: 2(0) \\
9: 11(2) \\
12: 14(4)\end{array}$ & $\begin{array}{l}24: 25(12) \\
18: 10(7) \\
23: 18(11)\end{array}$ \\
\hline June & $\begin{array}{l}\text { B. } \\
\text { M. } \\
\text { E. }\end{array}$ & $\begin{array}{l}22: 13(8) \\
13: 12(8) \\
16: 21(11)\end{array}$ & $\begin{array}{l}19: 16(10) \\
30: 25(18) \\
13: 9(5)\end{array}$ \\
\hline July & $\begin{array}{l}\text { B. } \\
\text { M. } \\
\text { E. }\end{array}$ & $\begin{array}{l}12: 15(12) \\
18: 14(10) \\
19: 21(11)\end{array}$ & $\begin{array}{l}41: 37(26) \\
23: 34(27) \\
19: 6(4)\end{array}$ \\
\hline Aug. & $\begin{array}{l}\text { B. } \\
\text { M. } \\
\text { E. }\end{array}$ & $\begin{array}{l}5: 10(6) \\
3: 5(2) \\
8: 14(9)\end{array}$ & $\begin{array}{c}7: 12(7) \\
14: 16(9) \\
30: 29(16)\end{array}$ \\
\hline Sept. & $\begin{array}{l}\text { B. } \\
\text { M. } \\
\text { E. }\end{array}$ & $\begin{array}{l}12: 8(6) \\
19: 24(17) \\
32: 27(21)\end{array}$ & $\begin{array}{l}34: 42(25) \\
28: 19(17) \\
17: 21(15)\end{array}$ \\
\hline Oct. & $\begin{array}{l}\text { B. } \\
\text { M. } \\
E .\end{array}$ & $\begin{array}{r}11: 13(4) \\
14: 12(7) \\
8: 11(2)\end{array}$ & $\begin{array}{l}5: 6(2) \\
4: 8(5) \\
3: 7(3)\end{array}$ \\
\hline Nov. & $\begin{array}{l}\text { B. } \\
\text { M. } \\
\text { E. }\end{array}$ & $\begin{array}{l}2: 5(3) \\
0 \div 2(1)\end{array}$ & $\begin{array}{cc}1: & 3(1) \\
3: & 5(3) \\
- & \end{array}$ \\
\hline
\end{tabular}

Figure in parenthesis shows the number of females with mature ovaries.

Generally speaking, in the giant straw piles $X$. galactinus was much more prevalent than L.beneficus. While in the straws from the farmer's barn, especially in wheat straws, L. beneficus was more prevalent. X.galactinus was seemed to prefer somewhat moist straw, although in some cases many 
individuals of this species were found in the very dry straw. L. beneficus was almost decidedly predominant in somewhat dry paddy straws (Table 24). However, in some cases, X.galactinus was found in the dry straw which was generally fitted for the life of L.beneficus. In such cases the latter species was never observed. Therefore, we can see a marked habitat segregation between both species. The competition and habitat segregation between these bugs will be well discussed in Chapter 15 .

Table 24. Predominancy of Lyctocoris beneficus and Xylocoris galactinus in relation to the straw condition.

\begin{tabular}{|c|c|c|c|c|}
\hline & \multicolumn{4}{|c|}{ Condition and kind of straw } \\
\hline & $\begin{array}{l}\text { Dry paddy } \\
\text { straw }\end{array}$ & $\begin{array}{l}\text { Moderately dry } \\
\text { paddy straw }\end{array}$ & $\begin{array}{l}\text { Wet paddy } \\
\text { straw }\end{array}$ & $\begin{array}{l}\text { Dry wheat } \\
\text { straw }\end{array}$ \\
\hline L. beneficus & $H \cdot \sim H$ & + & $+\sim-$ & Ht \\
\hline X.galactinus & + & 111 & IIt & + \\
\hline
\end{tabular}

The insect fauna in the straw pile is often comparatively complicated, and seems to be apparently influenced by the condition of straws. Especially humidity of straws seems to play an important role on the occurrence of Anthocorid bugs. The prevalent insects and other creatures in the straw pile are listed in Table 25.

The methods applied to the determination of prey in the field collected insects contain the microscopic examination of gut contents or excreta (Putman 1962, etc.), precipitin tests (Dempster 1960, 1963, Laughton et al. 1955), paper chromatographic analysis (Putman 1965), etc. These methods have proved useful in some circumstances, but all have certain limitations. The author at first tried the paper chromatographic analysis using Metcalf and Newell's solvent system (Metcalf and Newell 1962). But it was proved that this method can not be applicable at least against the author's materials. The results of both circular and ascending developments failed to the separation of pigments, and in addition to it, the amount of fluorescent substances were too small to be detected in the chromatographic technique. In the present work, one of the field collected insects was reared in the laboratory together with the Anthocorid bugs, and the prey-predator relationship was observed (Table 26).

The results of feeding test indicate that both species of bugs prefer to prey on mites and some other small animals, especially having soft-exoskeleton and sluggish movement, such as Dipterous and Lepidopterous larvae. And the bugs avoid to prey on insects with hard body-wall.

As former workers mentioned, some individuals of L.beneficus were attracted to the lamp during the summer season (Oho 1955c, Hiura 1957). According to the author's work in the summer season, the nocturnal activities of 
Table 25. List of dominant animals in relation to the straw conditions.

\begin{tabular}{|c|c|c|c|c|}
\hline & \multicolumn{4}{|c|}{ Condition of straw } \\
\hline & 1 & 2 & 3 & 4 \\
\hline Acarus siro Linné (Acaridae) & H & -+ & - & H \\
\hline Armandillidium vulgare Latreille (Armandillidiidae) & - & - & H & - \\
\hline Onychiurus pseudarmatus Miyoshi (Onychiuridae j & - & $H$ & H & \\
\hline Ctenolepisma villosa Escherrich (Lepismatidae) & + & + & - & + \\
\hline Teleogryllus emma (Ohmachi et Matsuura) (Gryllidae) & - & + & + & - \\
\hline Gryllus minor Shiraki (") & - & - & + & \\
\hline Anisolabis maritima Borelli (Psalididae) & - & - & + & - \\
\hline Trogium pulsatorium Linné (Trogiidae) & $H$ & - & - & + \\
\hline Stenopirates japonicus Esaki (Enicocephalidae) & - & - & - & H \\
\hline Physopleurella armata Poppius (Anthocoridae) & - & - & - & + \\
\hline Cardiastethus fulvescens (Walker) (" j & - & - & - & + \\
\hline Pyralis farinalis Linné (Pyralidae) & - & - & - & + \\
\hline Pterastichus Zonginquus Bates (Harpalidae) & - & - & + & + \\
\hline Philonthus macies Sharp (Staphylinidae) & - & - & + & - \\
\hline Philonthus sericans Sharp ("I) & - & + & + & - \\
\hline Falagria fovea Sharp ( ") & - & + & + & - \\
\hline Achenomorphus Zithocharoides Sharp ("I) & - & + & tt & - \\
\hline Platyola paradoxa Bernhauer ( "I) & - & - & + & - \\
\hline 0 petiopalpus obesus Westwood (Cleridae) & + & H & - & + \\
\hline Monotoma picipes Herbst (Rhizophagidae) & H & H & - & + \\
\hline Silvanuslewisi Reitter (Silvanidae) & + & + & + & - \\
\hline Silvanus necticollis Reitter ( & + & + & - & + \\
\hline Silanoprus scuticollis Walker ( & + & - & - & - \\
\hline Oryzaephilus surinamensis Linné("I) & + & - & - & + \\
\hline Cryptophagus cellaris Scopoli (Cryptophagidae) & + & - & - & - \\
\hline Cryptophilus obliteratus Reitter (Erotylidae) & - & + & H & - \\
\hline Holoparamerus signata Wollaston (Corylophidae) & + & + & - & + \\
\hline Stephostethus chinensis Reitter (Lathridiidae) & + & + & - & - \\
\hline Lathridius transversus Olivier ( & H & + & - & + \\
\hline Typhaea stercorea Linné (Mycetophagidae) & H & + & - & $\perp$ \\
\hline Tribolium castaneum (Herbst) (Tenebrionidae) & - & - & - & $\perp$ \\
\hline Anthicus confucii Marseul (Anthicidae) & + & Ht & - & + \\
\hline Anthicus floralis Linné ( $/ \mathrm{j}$ & - & H & - & + \\
\hline Anthicus tanakai Nomura ("I) & + & + & - & - \\
\hline Sitophilus oryzae Linné (Rhynchophoridae) & + & - & - & + \\
\hline Monomorium sp. (Formicidae) & - & + & $H$ & - \\
\hline Chlorops oryzae Matsumura (Chloropidae) & - & + & + & - \\
\hline
\end{tabular}


Table 26. Prey-predator relation between the two Anthocorid bugs (Lyctocoris beneficus and Xylocoris galactinus) and other insects found in the straw.

\begin{tabular}{|c|c|c|}
\hline & L. beneficus & X. galactinus \\
\hline Acarus siro & $H$ & H \\
\hline Armandillium vulgare & 0 & 0 \\
\hline Ctenolepisma villosa & $t-$ & $\ldots$ \\
\hline Anisolabis maritima & 0 & 0 \\
\hline Stenopirates japonicus & $\underline{.1}$ & $\underline{t}$ \\
\hline Pyralis farinalis & H & + \\
\hline Philonthus sericans & 0 & 0 \\
\hline O petiopalpus obesus & 0 & - \\
\hline Monomorium sp. & - & - \\
\hline Chlorops oryza & H & H \\
\hline \multicolumn{3}{|c|}{$\begin{array}{l}\text { H: frequently preyed by Anthocorid bugs. } \\
+: \text { preyed by Anthocorid bugs. } \\
0: \text { no prey-predator relation exists. } \\
\pm: \text { cannibalism was seen between the species. } \\
-: \text { Anthocorid bug was attacked. }\end{array}$} \\
\hline
\end{tabular}

both species began just before sunset and reached climax about 1 hour after sunset. As no sufficient specimens of L.beneficus were collected, the available data was obtained only on $X$. galactinus (Fig. 5).

The nocturnal activity of $X$. galactinus differs significantly between the sexes. A large number of male adults began to appear on the white organdy cloth which was spread on the ground just before sunset. Many male individuals were also caught at the lower zone, about O-2 meters in height. Later soon they flew high up to the light which was set at 5-6 $\mathrm{m}$ in height, and the peak of the number of attracted bugs was seen about one hour after sunset. The females began their nocturnal flight about half an hour later than that of male. At first, they aggregated on the white organdy cloth and later flew up to higher zone as in the case of males. The majority of collected specimens on the organdy cloth were male, while the female was predominant in the higher zone collection. The peak of the number of attracted females at light was observed between 7-9 PM. After this period, the females suddenly decreased in number and finally very few individuals were collected at the light. The nocturnal activity ceased at the end of September probably due to the cooler temperature. The active flight of the bugs were also observed under the laboratory temperature condition higher than $35^{\circ} \mathrm{C}$ and under strong illumination.

The nocturnal activity of female adult is seemed to have little correlation to the status of ovarian development, because the dissections of the 


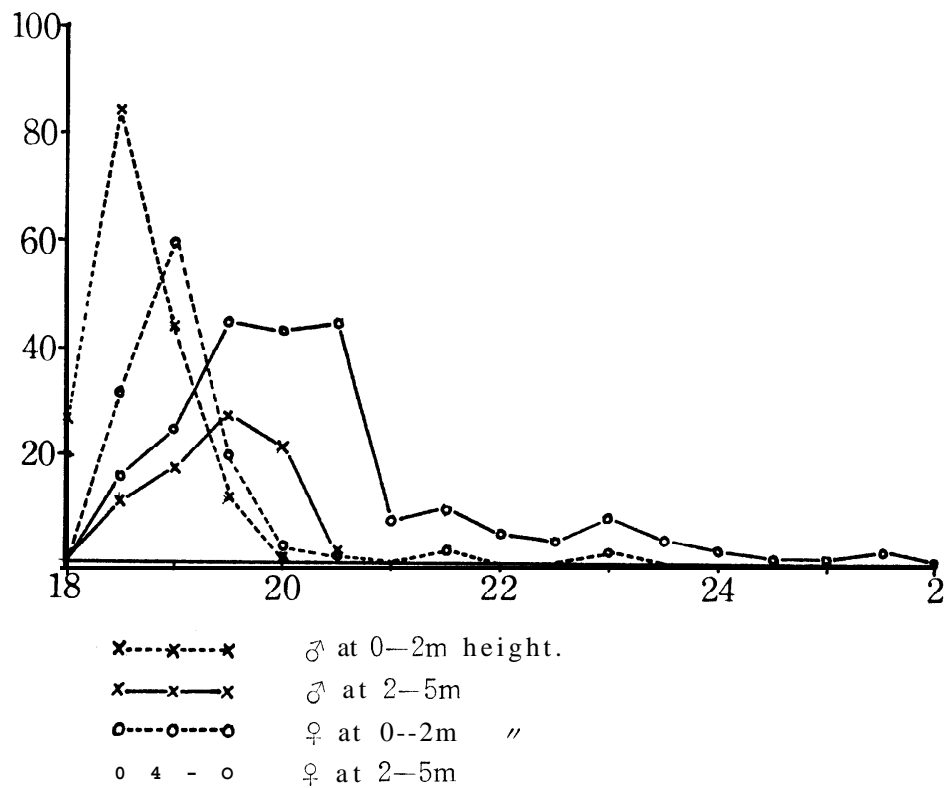

Fig. 5. Nocturnal activity of Xylocoris galactinus attracted to the light on Aug. 30th, 1967 (S unset at 18: 46 o'clock).

Abscissa : hour in o'clock. Ordinate: No. of bugs collected.

collected female specimens indicate the various stages of ovarian development.

To clear the life history in the field condition, a small straw pile was made in the campus of the university. Its size was about $1.5 \mathrm{~m}$ in length, width and height respectively. Five pairs of each species were placed in the $3 \times 5 \mathrm{~cm}$ (diameter $\mathrm{x}$ length) cylindrical screen cage in which the mite infested straws and the rice stem borer (Chilosuppressalis (Walker)) were provided as food. Then, the screen cage was inserted in the central part of the pile. Observations and supply of food were carried out once a week. When the bugs became too much crowded in a cage, a part of them were separated to another cage, and the observations were continued (Tables 27-28).

As seen in Tables 27 and 28, L. beneficus and X.galactinus might have 3 to 5 generations per annum. It seems that the first adult of each generation of L. beneficus appears in May, July, August, September and October. In $X$. galactinus, such adult may emerge in May, June, Iuly, August, September and November. As the oviposition period of the adults are long during the warmer seasons, each stage of bugs is observed or co-existed in the cage at the same time. According to the author's observation the last 
Table 27. Life cycle of Lyctocoris beneficus under the field condition.

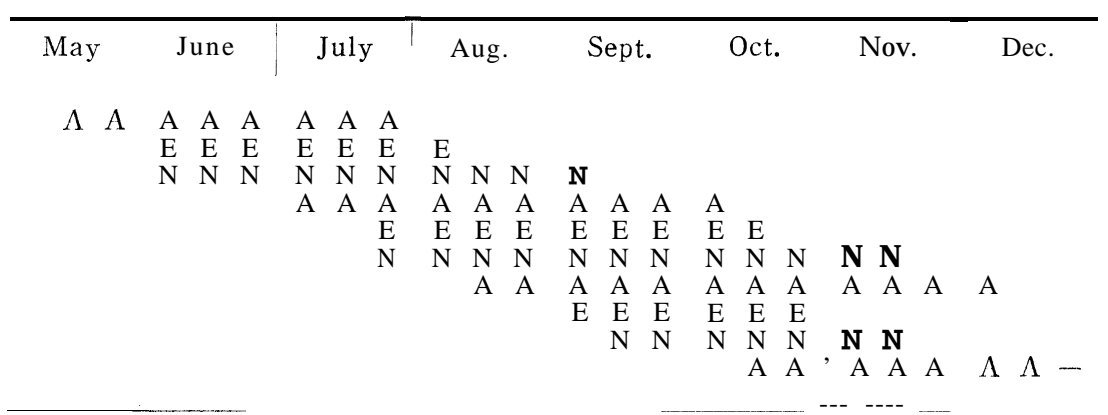

Table 28. Life cycle of Xylocoris galactinus under the field condition.

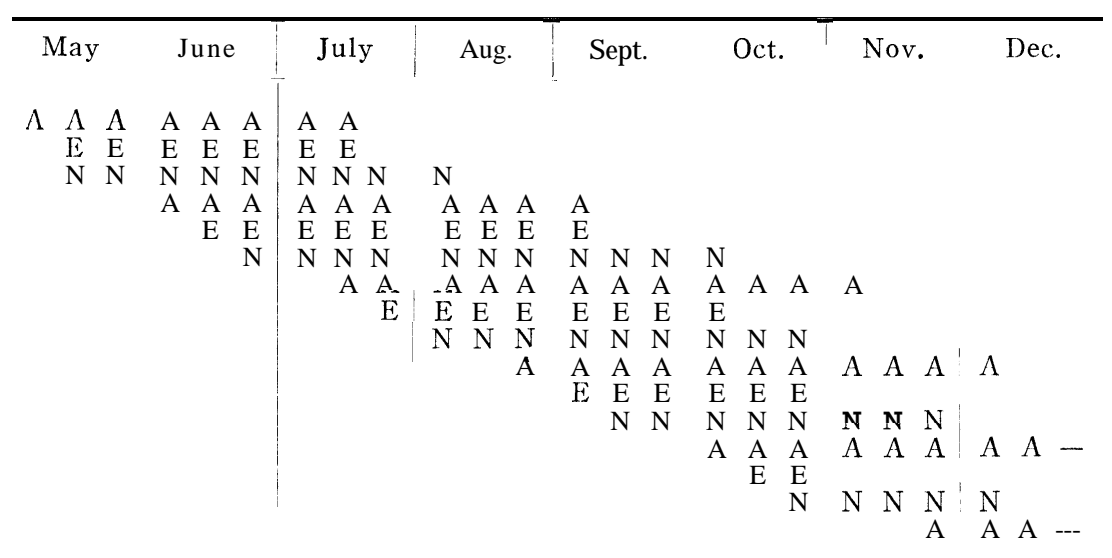

adult $\boldsymbol{L}$. beneficus died on $16 \mathrm{th}$, the lowest temperature being $1.2^{\circ} \mathrm{C}$, and $X$. galactinus on 9 th of December, the minimum temperature being $2.8^{\circ} \mathrm{C}$. The death was caused partly by the cold temperature of the season. But in the giant straw pile or in the stock yard, the adult can survive until the next spring in the inner warmer part of the pile.

\section{Preying habit}

\section{Preying record.}

Anthocorid bugs are generally known as polyphagous predators. For instance, Orius insidiosus (Say) has been recorded as a predator of 53 species of insects and mites (Marshall 1930). According to the prey list of Anthocoris nemorum (Linné) compiled by Hill (1957) and Collyer (1967), the species prey upon spiders, mites, aphids, midges, scale insects, Lygus bugs, etc. Although 
the preying range of Lyctocoris beneficus (Hiura) and Xylocoris galactinus (Fieber) have not investigated throughly, several insects were previously recorded as their prey under the laboratory or natural condition (Table 29).

Table 29. A list of previously known prey of Lyctocoris beneficus and Xylocoris galactinus.

L. beneficus

Brachmia triannulella H.-S. (Gelechiidae, Lep.) ${ }^{1)}$

Aedia leucomelas Linné (Noctuidae, Lep.) ${ }^{11}$

Sesamia inferens Walker (Noctuidae, Lep.) ${ }^{1)}$

Chilo suppressalis (Walker) (Pyralidae, Lep.) ${ }^{1,2)}$

Arga pagana Panzer (Argidae, Hym.)1)

Pachygrontha antennata Uhler (Lygaeidae, Heter.) ${ }^{11}$

Calaphis magnolicolens Takahashi (Aphididae, Homo.)2)

Hyalopterus arundinis Fabricius (Aphididae, Homo.)1)

Dactynitus gobonis Matsumura (Aphididae, Homo.)"

Aranea ${ }^{1)}$

X. galactinus

Laemophloeus ferrugineus (Stephen) (Cucujidae, Col.) ${ }^{3)}$

Haemolaelaps casalis (Berlese) (Laelaptidae, Acarina) ${ }^{3)}$

Tyrophagus casei (Oudemans) (Acaridae, Acarina) ${ }^{3)}$

Leidionychus krameri (G.\& R. Canestrini) (Uropodidae, Acarina) ${ }^{3)}$

1). Oho 1955c. 2). Hiura 1957. 3). Hall 1951.

As pointed out by Thompson (1951) that "An understanding of the behaviour of predacious insects and more particularly of the specificity of their host relation is therefore very necessary in any attempt to evaluate the importance of predators as controlling agents of injurious insect", a thorough investigation on the food range is indispensable on the studies of predators. In the present work, the author tested more than 60 species of insects and other small animals which are composed of paddy plant insect pests, citrus insect pests, straw dwelling insects and stored grain insect pests. The inclusion of the last group of insects was intended mainly for the purpose of finding some preferable prey for the mass culture of bugs under the laboratory condition. The feeding responses of I;. beneficus and $X$.galactinus against these animals are given in Table 30 .

As seen in Table 30, both $L$. beneficus and $X$. galactinus have a wide food range, including 45 species of 23 families and 43 species of 22 families as prey respectively. Though some variations were observed between the two species on the intensity of response to prey, this fact may indicate a close correlation between the body size of prey and predator. In another word, 
Table 30. The feeding response of Lyctocoris beneficus and Xylocoris galactinus to various prey.

\begin{tabular}{|c|c|c|c|}
\hline Prey & $\begin{array}{l}\text { Stage } \\
\text { of prey }\end{array}$ & $\begin{array}{l}\text { Response of } \\
\text { L. beneficus }\end{array}$ & $\begin{array}{l}\text { Response of } \\
X \text {. galactinus }\end{array}$ \\
\hline $\begin{array}{c}\text { Ctenolepisma villosa Escherich } \\
\text { (Lepismatidae Thysa.) }\end{array}$ & $A-N$ & + & + \\
\hline $\begin{array}{c}\text { Thermobia domestica Packard } \\
\text { (Lepismatidae Thysa.) }\end{array}$ & $A-N$ & + & + \\
\hline $\begin{array}{l}\text { Periplaneta fuliginosa Serville } \\
\text { (Blattidae Blatt.) }\end{array}$ & $\mathrm{N}$ & -- & - \\
\hline $\begin{array}{l}\text { Coptotermes formosanus Shiraki } \\
\text { (Rhinotermitidae Iso.) }\end{array}$ & $A-N$ & -I- & + \\
\hline $\begin{array}{l}\text { Liposcelis entomophilus Enderlein } \\
\quad \text { (Liposcelidae Psoco.) }\end{array}$ & $A-N$ & H & $H$ \\
\hline $\begin{array}{l}\text { Trogium pulsatorium Linné } \\
\text { (Trogiidae Psoco.) }\end{array}$ & $A-N$ & tt & $H$ \\
\hline $\begin{array}{l}\text { Scotinophara lurida Burmeister } \\
\text { (Pentatomidae Heter.) }\end{array}$ & $\mathrm{N}$ & - & - \\
\hline $\begin{array}{l}\text { Lagynotomus elongatus Dallas } \\
\text { (Pentatomidae Heter.) }\end{array}$ & $\mathrm{N}$ & - & - \\
\hline $\begin{array}{l}\text { Nezara antennata Scott } \\
\text { (Pentatomidae Heter.) }\end{array}$ & $\mathrm{N}$ & - & - \\
\hline $\begin{array}{l}\text { Nephotettix cincticeps (Uhler) } \\
\text { (Cicadellidae Homo.) }\end{array}$ & $A-N$ & + & + \\
\hline $\begin{array}{l}\text { Laodel phax striatellus (Fallén) } \\
\text { (Delphacidae Homo.) }\end{array}$ & $A-N$ & + & + \\
\hline $\begin{array}{c}\text { Nilaparvata lugens(Stål) } \\
\text { (Delphacidae Homo.) }\end{array}$ & $A-N$ & + & + \\
\hline $\begin{array}{l}\text { Sogatella furcifera Horváth } \\
\text { (Delphacidae Homo.) }\end{array}$ & $A-N$ & + & + \\
\hline $\begin{array}{l}\text { Cinara piniformosa Takahashi } \\
\text { (Adelgidae Homo.) }\end{array}$ & $A-N$ & + & + \\
\hline $\begin{array}{l}\text { Acyrthosiphon pisum Harris } \\
\text { (Aphididae Homo.) }\end{array}$ & $A-N$ & |f- & $-H-$ \\
\hline $\begin{array}{l}\text { Aphis gossypii Glover } \\
\text { (Aphididae } \text { Homo.) }\end{array}$ & $A-N$ & -If- & H \\
\hline $\begin{array}{l}\text { Brevicoryne brassicae (Linné) } \\
\text { (Aphididae Homo.) }\end{array}$ & $\mathrm{A}-\mathrm{N}$ & $H$ & $H$ \\
\hline $\begin{array}{c}\text { Calaphis magnolicolens Takahashi } \\
\text { (Aphididae Homo.) }\end{array}$ & $A-N$ & $H$ & $H$ \\
\hline
\end{tabular}




\begin{tabular}{|c|c|c|c|}
\hline Prey & $\begin{array}{l}\text { Stage } \\
\text { of prey }\end{array}$ & $\begin{array}{l}\text { Response } \\
\text { L. beneficus }\end{array}$ & $\begin{array}{l}\text { of Response of } \\
S \mathbf{X} \text {. galactinus }\end{array}$ \\
\hline $\begin{array}{l}\text { Hyalopterus arundinis Fabricius } \\
\text { (Aphididae Homo.) }\end{array}$ & $A-N$ & $H$ & $H$ \\
\hline $\begin{array}{l}\text { Macrosiphum avenae Shinji } \\
\text { (Aphididae Homo.) }\end{array}$ & $A-N$ & $H$ & $H$ \\
\hline $\begin{array}{l}\text { Melanaphis bambusae (Fullaway) } \\
\text { (Aphididae Homo.) }\end{array}$ & $A-N$ & $H$ & $H$ \\
\hline $\begin{array}{l}\text { Myzus persicae (Sulzẹr) } \\
\text { (Aphididae Homo. j }\end{array}$ & $A-N$ & $\mathrm{t} \mathrm{t}$ & $H$ \\
\hline $\begin{array}{l}\text { Shivaphis celti Das } \\
\text { (Aphididae Homo.) }\end{array}$ & $A-N$ & $H$ & $H$ \\
\hline $\begin{array}{l}\text { Toxoptera aurantii (Boyer) } \\
\text { (Aphididae Homo.) }\end{array}$ & $A-N$ & $\mathrm{t} \mathrm{t}$ & $H$ \\
\hline $\begin{array}{l}\text { Trichosiphoniella sasakii Matsumura } \\
\text { (Aphididae Homo.) }\end{array}$ & $A-N$ & $H$ & H \\
\hline $\begin{array}{l}\text { Dialeurodes citri Ashmead } \\
\text { (Aleyrodidae Homo.) }\end{array}$ & $\mathrm{N}$ & - & - \\
\hline $\begin{array}{l}\text { Icerya seyschellarum Westwood } \\
\text { (Margarodidae Homo.) }\end{array}$ & $A-N$ & - & - \\
\hline $\begin{array}{l}\text { Phenacoccus azalea Kuwana } \\
\text { (Pseudococcidae Homo.) }\end{array}$ & $A-N$ & - & - \\
\hline $\begin{array}{l}\text { Ceroplastis pseudoceriferus Green } \\
\text { (Coccidae Homo.) }\end{array}$ & $A-N$ & - & - \\
\hline $\begin{array}{l}\text { Ceroplastis rubens Maskell } \\
\text { (Coccidae Homo.) }\end{array}$ & $A-N$ & - & - \\
\hline $\begin{array}{l}\text { Aonidiella aurantii (Maskell) } \\
\text { (Diaspidae Homo.) }\end{array}$ & $A-N$ & - & - \\
\hline $\begin{array}{l}\text { Chrysomphalus bifasciculatus Ferris } \\
\text { (Diaspidae Homo.) }\end{array}$ & $A-N$ & - & - \\
\hline $\begin{array}{l}\text { Hemiberlesia rapax (Cornstock) } \\
\text { (Diaspidae Homo.) }\end{array}$ & $A-N$ & - & - \\
\hline $\begin{array}{l}\text { Pseudaulacaspis pentagona (Targioni) } \\
\text { (Diaspidae Homo.) }\end{array}$ & $A-N$ & - & - \\
\hline $\begin{array}{l}\text { Unaspis yanonensis Kuwana } \\
\text { (Diaspidae Homo.) }\end{array}$ & $A-N$ & - & - \\
\hline $\begin{array}{l}\text { Nemapogon granella Linné } \\
\text { (Tineidae Lep.) }\end{array}$ & $\mathrm{L}$ & - & - \\
\hline $\begin{array}{l}\text { Canephora asiatica (Staudinger) } \\
\text { (Psychidae Lep.) }\end{array}$ & $\mathrm{L}$ & - & - \\
\hline
\end{tabular}


Prey

Mahasena minuscula (Butler)

(Psychidae Lep.)

\section{Phyllocnistis citrella Stainton} (Gracilariidae Lep.)

\begin{tabular}{|c|c|c|c|}
\hline $\begin{array}{l}\text { Adoxophyes orana Fischer } \\
\text { (Tortricidae Lep.) }\end{array}$ & $\mathrm{L}$ & -t- & + \\
\hline $\begin{array}{l}\text { Brachmia triannulella H.-S. } \\
\text { (Gelechiidae Lep.) }\end{array}$ & $\mathrm{L}$ & ii- & + \\
\hline $\begin{array}{l}\text { Sitotroga cerealella (Olivier) } \\
\text { (Gelechiidae Lep.) }\end{array}$ & $\mathrm{L}$ & - & - \\
\hline $\begin{array}{c}\text { Aphomia gularis (Zeller) } \\
\text { (Pyralidae Lep.) }\end{array}$ & $\mathrm{L}$ & - & - \\
\hline $\begin{array}{l}\text { Chilo suppressalis (Walker) } \\
\text { (Pyralidae Lep.) }\end{array}$ & $\mathrm{L}$ & $i-t$ & + \\
\hline $\begin{array}{l}\text { Cnaphalocrocis medinalis Guénee } \\
\text { (Pyralidae Lep.) }\end{array}$ & $\mathrm{L}$ & $H$ & + \\
\hline $\begin{array}{c}\text { Cadra cautella (Walker) } \\
\text { (Pyralidae Lep.) }\end{array}$ & $\mathrm{L}$ & - & - \\
\hline $\begin{array}{l}\text { Galleria mellonella (Linné) } \\
\text { (Pyralidae Lep.) }\end{array}$ & $\mathrm{L}$ & -ii- & -II- \\
\hline $\begin{array}{l}\text { Plodia interpunctella (Hiibner) } \\
\text { (Pyralidae Lep.) }\end{array}$ & $\mathrm{L}$ & - & - \\
\hline $\begin{array}{l}\text { Pyralis farinalis Linné } \\
\text { (Pyralidae Lep.) }\end{array}$ & $\mathrm{L}$ & $H$ & $H$ \\
\hline $\begin{array}{c}\text { Susumia exigua Butler } \\
\text { (Pyralidae Lep.) }\end{array}$ & $\mathrm{L}$ & $H$ & H \\
\hline $\begin{array}{l}\text { Tryporyza incertulas (Walker } \mathrm{j} \\
\text { (Pyralidae Lep.) }\end{array}$ & $\mathrm{L}$ & tt & + \\
\hline $\begin{array}{l}\text { Naranga aenescens Moore } \\
\text { (Noctuidae Lep.) }\end{array}$ & $\mathrm{L}$ & H & + \\
\hline $\begin{array}{l}\text { Prodenia litura (Fabricius) } \\
\text { (Noctuidae Lep.) }\end{array}$ & $\mathrm{L}$ & + & + \\
\hline $\begin{array}{c}\text { Sesamia inferens Walker } \\
\text { (Noctuidae Lep.) }\end{array}$ & $\mathrm{L}$ & $H$ & + \\
\hline $\begin{array}{c}\text { Parnara guttata } \\
\text { (Hesperidae } \\
\text { Lep.) }\end{array}$ & $\mathrm{L}$ & + & - \\
\hline $\begin{array}{l}\text { Cryptolestes minutus Olivier } \\
\text { (Silvanidae Col.) }\end{array}$ & $\mathrm{L}$ & tt & $H$ \\
\hline
\end{tabular}
of prey L. beneficus $X$. galactinus

$\mathrm{L}$

L

$+\quad+$

Stage Response of Response of

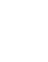




\begin{tabular}{|c|c|c|c|}
\hline Prey & $\begin{array}{l}\text { Stage } \\
\text { of prey }\end{array}$ & $\begin{array}{l}\text { Response of } \\
\text { L. beneficus }\end{array}$ & $\begin{array}{l}\text { Response of } \\
X . \text { galactinus }\end{array}$ \\
\hline $\begin{array}{l}\text { Oryzaephilus surinamensis Linné } \\
\text { (Silvanidae Col.) }\end{array}$ & $\mathrm{L}$ & -li & tt \\
\hline $\begin{array}{l}\text { Korynetes coerulens Degeer } \\
\text { (Cleridae Col.) }\end{array}$ & $\mathrm{L}$ & $H$ & + \\
\hline $\begin{array}{l}\text { Temnochila japonica Reitter } \\
\text { (Trogostidae Col.) }\end{array}$ & $\mathrm{L}$ & --- & - \\
\hline $\begin{array}{l}\text { Teneboides mauritanicus Linné } \\
\text { (Trogositidae Col.) }\end{array}$ & $\mathrm{L}$ & - & - \\
\hline $\begin{array}{l}\text { Rhizopertha dominica Fabricius } \\
\text { (Bostrychidae Col.) }\end{array}$ & $\mathrm{L}$ & $H$ & $H$ \\
\hline $\begin{array}{l}\text { Tenebrio molitor Linné } \\
\text { (Tenebrionidae Col.) }\end{array}$ & $\mathrm{L}$ & $H$ & tt \\
\hline $\begin{array}{l}\text { Tribolium castaneum (Herbst) } \\
\text { (Tenebrionidae Col.) }\end{array}$ & $\mathrm{L}$ & $H$ & $H$ \\
\hline $\begin{array}{l}\text { Sitophilus oryzae Linné } \\
\text { (Rhynchophoridae Col.) }\end{array}$ & $\mathrm{L}$ & $\downarrow \mathrm{I}-$ & $-t+\cdot$ \\
\hline $\begin{array}{l}\text { Musca domestica Linné } \\
\text { (Muscidae Dip.) }\end{array}$ & $\mathrm{L}$ & - & - \\
\hline $\begin{array}{l}\text { Chlorops oryzae Matsumura } \\
\text { (Chloropidae Dip.) }\end{array}$ & $\mathrm{L}$ & $H$ & $H$ \\
\hline $\begin{array}{l}\text { Sarcophaga sp. } \\
\quad \text { (Sarcophagidae Dip.) }\end{array}$ & $\mathrm{L}$ & - & - \\
\hline $\begin{array}{l}\text { Chironomus sp. } \\
\text { (Chironomidae Dip.) }\end{array}$ & $\mathrm{L}$ & -- & - \\
\hline $\begin{array}{l}\text { DD-136 } \\
\quad \text { (Nematodes) }\end{array}$ & A-L & - & -- \\
\hline $\begin{array}{l}\text { Armadillidium vulgare Latreille } \\
\text { (Armadillidiidae Isopoda) }\end{array}$ & A & - & - \\
\hline $\begin{array}{l}\text { Acarus siro Linné } \\
\text { (Acaridae Acarina) }\end{array}$ & $A-N$ & $\mathrm{H} \cdot \mathrm{H}$ & $H$ \\
\hline $\begin{array}{l}\text { Carpoglyphus lactis Linné } \\
\text { (Carpoglyphidae Acarina) }\end{array}$ & $A-N$ & II & $H$ \\
\hline $\begin{array}{l}\text { Panonychus citri McGregor } \\
\text { (Tetranychidae Acarina) }\end{array}$ & $A-N$ & 11 & H \\
\hline
\end{tabular}

smaller sized X. galactinus is not fitted to attack the larger-sized prey. Further, it is said that both species of bugs prey on the comparatively less active larvae of Lepidoptera, Coleoptera, Aphis and mites, etc. The negative response shown in the case of some Pentatomid bugs may probably due to its well-developed exoskeleton. The Muscid and Sarcophagid larvae were also unsuitable for food probably due to its elastic cuticle and vigorous 
movement responded against the first attack by the predator. Silver fishes and leafhoppers were not preferable food for the bugs, because of their alertness. It is rather worthy of mention that the larvae of stored product Lepidopterous pests, namely Plodia interpunctella(Hübner), Sitotroga cerealella (Olivier), Aphomia gularis (Zeller) and Cadracautella (Walker) were not suitable food of bugs, and bugs afforded with these larvae as food starved to death finally, though the other Lepidopterous larvae were served as good prey for them. In addition to this phenomenon, high mortality of bugs was observed in such insects infesting corn media. This is partly due to the tangling of bug's legs by the secreted thread of Lepidopterous larvae.

II. Feeding preference.

The food preference experiments of L.beneficus and $X$. galactinus were carried out using the larvae of Galleria mellonella(Linné), Chilo suppressalis (Walker) and Celaphis magnolicolens Takahashi. Five individuals of Lepidopterous larvae, 20 of Tribolium larvae and C. magnolicolens were provided in a $9 \times 8 \mathrm{~cm}$ petri-dish which contained 10 adults or 3rd instar nymphs of predator. Among the prey provided, aphids were afforded with a leaf of Magnolia obovata Thunberg, and the other prey were placed in the petridish without any shelter or so. The number of dead or damaged prey was counted after 24 hours. Table 31 shows the average of 10 replications.

Table 31. Feeding preference of Lyctocoris beneficus and Xylocoris galactinus against four kinds of prey (10 bugs in each test, average of 10 tests).

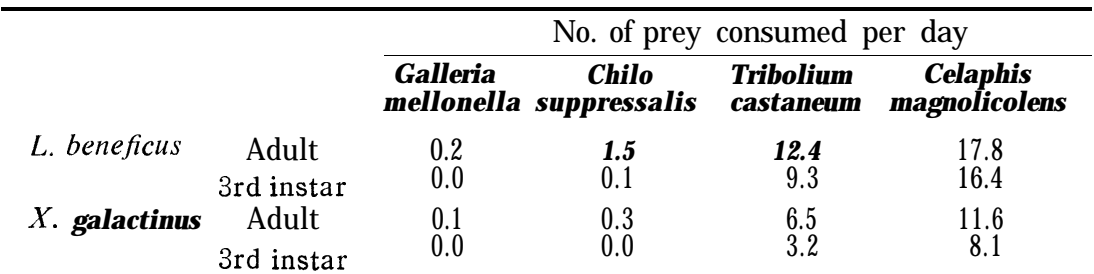

As indicated in Table 31, it is evident that both adult and nymph of L. beneficus feed more prey than X. galactinus do. It is undoubtedly due to the larger size of the former species. The effect of body size of the predator on the food amount consumed was more significantly observed in the number of aphids preyed. The preference order was C. magnolicolens, T. castaneum, C. suppressalis and G. mellonella, and this tendency was similarly observed in each species. This test also indicated that the Lepidopterous larvae were not preferred prey. If the predators were not afforded with aphids or flour beetles, the bugs attacked the Lepidopterous larvae very frequently especially when the bugs were put into the dish in large numbers or gregariously. 
The prey preference of bugs among the larvae of C. suppressah, Tryporyza incertulas Walker and G. mellonella was also tested, but no significant differences of preference were observed among the provided materials (Table 32).

Table 32. Feeding preference of Lyctocoris beneficus and Xylocoris galactinus against three kinds of Lepidopterous larvae (10 predators and 5 prey of each species).

\begin{tabular}{ccccc}
\hline & & $\begin{array}{c}\text { No. of prey consumed per day } \\
\text { Chilo } \\
\text { suppressalis }\end{array}$ & $\begin{array}{c}\text { Tryporyza } \\
\text { incertulas }\end{array}$ & $\begin{array}{c}\text { Galleria } \\
\text { mellon } \text { ella }\end{array}$ \\
L. beneficus & Adult & 2.4 & 2.2 & 1.8 \\
& 3rd instar & 2.2 & 2.1 & 1.1 \\
X. galactinus & Adult & 1.3 & 0.9 & 0.8 \\
& 3rd instar & 0.2 & 0.4 & $\mathbf{0 . 2}$ \\
\hline
\end{tabular}

The number of attacked insects indicated in this table was apparently smaller than the result shown in Table 34. This may be attributed to the fact that the bugs prefer rather inactive larvae or damaged individuals to healthy and active ones. Therefore, preyed larvae were frequently faced to death with a number of pierced scars. However, the bugs avoid to attack the dying or dead larvae. As the food preference of bugs seemed to be greatly influenced by the body size of prey, larvae of G. mellonella were divided into three groups by their body weight, namely 1) more than $150 \mathrm{mg}$, 2) between $150 \mathrm{mg}$ and $70 \mathrm{mg} \mathrm{3}$ ) less than $70 \mathrm{mg}$ and each group was used for experiments to compared the response of bugs against the various sized prey (Table 33).

Table 33. Number of punctures found on Galleria mellonella larvae of different weight by Lyctocoris beneficus and Xylocoris galactinus (24 hour exposure against 1.0 predators).

\begin{tabular}{ccccc}
\hline & & Range of & body weight & $(\mathrm{mg})$ \\
& & $>150$ & $150-70$ & $<70$ \\
L. beneficus & Adult & 4.5 & $\mathbf{8 . 6}$ & $\mathbf{1 3 . 3}$ \\
& 3rd instar & 2.2 & 7.4 & 11.5 \\
X. galactinus & Adult & 0.3 & 8.1 & 12.4 \\
& 3rd instar & 0.0 & 6.0 & 9.2
\end{tabular}

The larva of G. mellonella is rich enough with blood. According to Richardson et al. (1931) it is about $4 \%$ of body weight. On the other hand, the maximum feeding amount per one meal by the adult $L$. beneficus does not exceed $0.5 \mathrm{mg}$. Therefore, the feeding amount of the nymph of $\mathbf{L}$. beneficus, adult and nymph of $\mathrm{X}$. galactinus is seemed, of course, to be less than that 
of the adult L. beneficus. Consequently, even the smallest-sized Galleria larvae may provided adequate amount of food to satisfy the predator's appetite. From this reason, the increase of the number of punctures on the body surface of smaller larvae may not explain the insufficiency of blood supply at one meal even in the adult L. beneficus, but it is rather demonstrating the accessibility of the smaller larvae by the predators.

\section{Feeding behaviour.}

Several steps are normally observed in the feeding behaviour of L. beneficus and $X$.galactinus: 1 ) The antennae, which are usually held in a bended position in the resting insect, are stretched forward straightly towards the prey in front of the head ; 2) the bug approaches straightly the prey ; 3) The bug depresses the anterior part of body, rises its fore legs and extends its proboscis forwards ; 4) Then, the bug pounces the prey and almost at the same time inserts its proboscis. The prey becomes inactive immediately after the insertion. It seems probable to the author that an anaesthetizing fluid might be injected into the wound simultaneously with the insertion of its proboscis. One meal of L. beneficus took 2 to 4 minutes and that of X. galactinus was a little shorter. In the case of Tribolium larvae, one attack by the bug is fatal to the larvae which will be mummified soon after the attack. In the relatively matured larvae of the rice stem borer or the wax moth, no individuals died immediately after the attack. But, the blood sucked prey are weakened gradually and easily accept additional attacks by the other bugs. The wound on the body wall of prey is noticed as a small black speck which enlarges later and changes to a black necrosis area. Even if the damaged larvae were fortunately free from the second attack or intentionally separated from predators, majority of them died within 48 hours. In a very few cases some individuals succeeded to pupate or to make cocoons, but all the pupae failed to accomplish their pupal development. No particular parts of the prey's body seemed to be favoured by the predators, because in the damaged larvae the punctures occur either on the segment or on the intra-segmental membrane from prothorax to telson.

\section{Food requirement and daily consumption.}

To evaluate the bugs as natural enemies or to establish a method of mass production of the bugs, it is necessary to make further detailed observations on the feeding habit of the bugs. To acquire more precise data on the food requirement by a single bug, an adult of both species was reared separately in a $50 \mathrm{ml}$ beaker which is provided with 3 individuals of mature larvae of C. suppressalis, or 3rd instar larvae of G. mellonella or 3 mature larvae of T. castaneum. And the number of preyed larvae was counted daily (Table 34). The adults provided in this test were fed with the larvae of T. castaneum during their nymphal stages. 
Table 34. Number of daily consumed prey during the adult stage of Lyctocoris beneficus and Xylocoris galactinus (average of 10 days test, with 10 predators).

\begin{tabular}{lccc}
\hline & $\begin{array}{c}\text { Chilo } \\
\text { suppressalis }\end{array}$ & $\begin{array}{c}\text { Galleria } \\
\text { mellonella }^{2)}\end{array}$ & $\begin{array}{l}\text { Tribolium } \\
\text { castaneum }^{1)}\end{array}$ \\
L. beneficus & 0.7 & 1.3 & 2.1 \\
X. galactinus & 0.2 & 0.5 & 0.8 \\
1) : mature larvae. & & & \\
2) : pre-mature larvae. & & &
\end{tabular}

The results of tests almost coincided with the preceding one. Namely, the frequency of attack was proportional to the body size of prey. Though it is difficult to discuss the importance of the Anthocorid bugs as the predators against the rice stem borer merely from this data, L. beneficus is seemed to be an excellent predator, so far as its attack of the borer mainly in the field condition was concerned. X. galactinus is surely less efficient than $L$. beneficus in the solitary condition, and often the former species is crushed down by the borer when it pounced upon. Neverthfess, it is an efficient predator too when they occur gregariously.

The daily food requirement of the nymphs was estimated with the larvae of $T$. castaneum only, because the large-sized Lepidopterous larvae were unsuitable for the food of nymphs of both species in a solitary condition (Tables $35 \& 36$ ).

Table 35. Number of consumed Tribolium castaneum larvae in the nymphal stage of Lyctocoris beneficus.

\begin{tabular}{crrr}
\hline Instar of bug & A & B & C \\
\hline 1st & 3.4 & 1.8 & 0.53 \\
2nd & 4.6 & 3.4 & 0.74 \\
3rd & 5.2 & 5.2 & 1.00 \\
4 th & 4.0 & 6.6 & 1.65 \\
5th & 8.2 & 14.0 & 1.70 \\
Total & 25.4 & 33.0 & 1.30 \\
A : duration of instar in days. & & \\
B : number of larvae preyed during the instar. & \\
C : A daily consumption of prey. &
\end{tabular}

Table 35 indicates that the nymph of L.beneficus accomplished its nymphal development after consuming 33 Tribolium larvae and about $44 \%$ of the prey was consumed during the last nymphal stage. The daily con- 
Table 36. Number of consumed Tribolium castaneum larvae in the nymphal stage of Xylocoris galactinus.

\begin{tabular}{cccc}
\hline Instar of bug & $\mathrm{A}^{*}$ & $\mathrm{~B}^{*}$ & $\mathrm{C}^{*}$ \\
1st & 2.2 & 1.1 & 0.50 \\
2nd & 2.6 & 1.4 & 0.54 \\
3rd & 4.4 & 2.6 & 0.59 \\
4 th & 3.6 & 2.4 & 0.66 \\
5 th & 4.8 & 3.4 & 0.71 \\
Total & 17.6 & 10.9 & 0.61 \\
\hline * abbreviation same as that of Table 35. & &
\end{tabular}

sumption was seemed to be suddenly increased from the fourth instar. In $\mathrm{X}$. galactinus (Table 36), it consumed only about 11 larvae during its nymphal stage. Contrary to L. beneficus, the consumption gradually increased from 0.50 to 0.71 prey per day through the whole instars. Difference in daily consumption between adult and nymph was less pronounced in X.galactinus than in L. beneficus, $0.8: 0.7$ and $2.1: 1.7$ respectively. In the actual amount of daily consumption of Tribolium larvae by the mature nymph of L. beneficus was still prevalent to that of the adult of $\mathrm{X}$. galactinus.

The nutritional value of Tribolium larvae against each instar of bugs was expressed by the predatory value and conversion ratio which were introduced by Fewks (1960) and Evans (1962) respectively. Also the nutritional value of larvae of $C$. suppressalis, G. mellonella and T. castaneum against the adult stage was evaluated with the same formula.

The value of conversion ratio and predatory value were calculated using the following expressions.

$$
\begin{aligned}
& \text { Conversion ratio }=\begin{array}{r}
\text { Increase in weight } \\
\text { Weight consumed }
\end{array} \times 100 \\
& \text { Predatory value }=- \text { Weight consumed during instar }_{\text {Duration of instar }}^{\text {con }}
\end{aligned}
$$

where all weights are fresh weights.

In this test, the predator was kept singly and provided with weightknown prey. The predator and prey were inspected and weighed daily and fresh prey was provided if necessary. The weighing was done on a single pan automatic balance weighing to $0.1 \mathrm{mg}$. From the daily inspection it was possible to obtain a record of the weight of food consumed by the predators during their development, and the results were given in Tables 37 and 38. As the first instar was too light to be weighed, the works were started from the second instar. 
Table 37. Conversion ratio and predatory value of Lyctocoris beneficus nymph fed on Tribolium castaneum.

\begin{tabular}{|c|c|c|c|c|}
\hline & \multicolumn{4}{|c|}{ Tnstar of nymph } \\
\hline & 2nd & $3 \mathrm{r}$ & 4 th & 5 th \\
\hline Initial weight $(\mathrm{mg})$ & 0.2 & 0.6 & 1.1 & 1.4 \\
\hline $\begin{array}{l}\text { Initial weight of the } \\
\text { succeeding instar }(\mathrm{mg})\end{array}$ & 0.6 & 1.1 & 1.4 & 2.2 \\
\hline Increase in weight $(\mathrm{mg})(\mathrm{A})$ & 0.4 & 0.5 & 0.3 & 0.8 \\
\hline Weight of food consumed $(\mathrm{mg})(\mathrm{Bj}$ & 0.7 & 0.9 & 1.3 & 2.2 \\
\hline Conversion ratio $(\%)(\mathrm{A} / \mathrm{B})$ & 57.1 & 55.6 & 44.3 & 36.4 \\
\hline Duration of instar (in 'days) (C) & 7.1 & 7.3 & 7.8 & 11.8 \\
\hline Predatory value $(\mathrm{mg} / \mathrm{dayj}(\mathrm{B} / \mathrm{C} \mathrm{j}$ & 0.10 & 0.12 & 0.17 & 0.19 \\
\hline
\end{tabular}

Table 38. Conversion ratio and predatory value of Xylocoris galactinus nymph fed on Tribolium castaneum.

\begin{tabular}{lcccc}
\hline & \multicolumn{3}{c}{ Instar of nymph } \\
\cline { 2 - 5 } & 2 nd & 3 rd & 4 th & 5 th \\
\hline Initial weight (mg) & 0.2 & 0.3 & 0.5 & 0.8 \\
Initial weight of the & 0.3 & 0.5 & 0.8 & 1.3 \\
succeeding instar (mg) & & & & \\
Increase in weight (mg) (A) & $\mathbf{0 . 1}$ & 0.2 & 0.3 & 0.5 \\
Weight of food consumed (mg) (Bj & 0.2 & 0.5 & 0.8 & 1.5 \\
Conversion ratio (\%) (A/B) & 50.0 & 40.0 & 37.5 & 33.3 \\
Duration of instar (in days) (C) & 4.3 & 7.2 & 8.4 & 9.2 \\
Predatory value (mg/day) (B/C) & 0.05 & 0.07 & 0.09 & 0.16
\end{tabular}

The data indicated in Tables 37 and 38 have some variations from the results of previous experiments both in the duration of nymphal stage and the amount of food consumed. This was probably due to the excessive handling of materials by daily weighing, and high mortality of nymphs was also observed. Although the bugs were too small to make accurate estimation, the data showed higher conversion ratio in $\mathbf{L}$. benefzcus than in $\mathrm{X}$. galactinus. And earlier instars showed a higher conversion ratio than the later ones as observed in Cimex lectularius Linné and Phonoctonus nigrofasciatus Stål by Johnson (1960) and Evans (1962) respectively. Compared with $X$. galactinus, the conversion ratio of $\mathbf{L}$. beneficus was higher through 4 nymphal stages. This may suggest that L. beneficus nymph has more efficient metabolic mechanism than $\mathrm{X}$. galactinus. The predatory value was lower in earlier instars in both species. The lower conversion ratio and higher predatory value of the late nymphal instars may prove the active predatory action of mature nymphs. 
The nutritional value of 3 kinds of foods against L. beneficus and X. galactinus was estimated with the newly emerged female adults for ten days. The weight change and feeding record were illustrated in Figs. 6 and 7 , and the result was also summarized in Table 11 with the value of conversion ratio and predatory value. The materials used in this test were fed to the adult with $\mathbf{T}$. castaneum larvae.

As seen from Figures, the body weight of L. beneficus increased almost stably irrespective of kinds of prey provided. While in $\mathbf{X}$. galactinus, the stability of body weight was only observed in individuals afforded with Tribolium. And even the decrease of body weight was observed in Chilofed individuals. This is apparently indicating the unsuitability of those larvae as food of $\mathbf{X}$. galactinus at least in the solitary rearing condition. The increase of body weight was apparently depending upon the development of ovaries, and this was ascertained by the swelling of abdomen as well as the anatomical dissection.

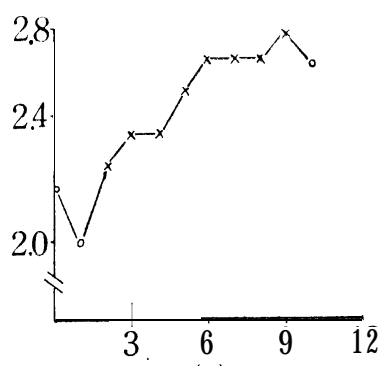

(A)

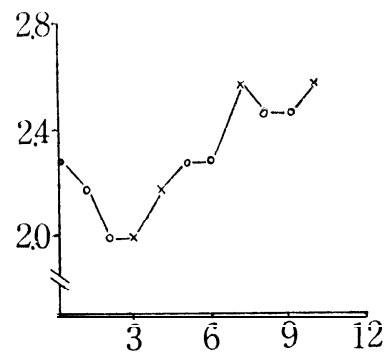

(B)

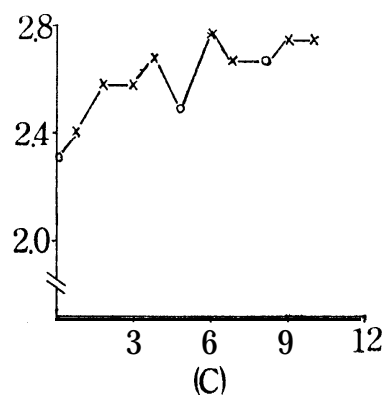

Fig. 6. Feeding record and body weight change of the adult female Lyctocoris beneficus; Abscissa, body weight of bug (mg) ; ordinate, days from emergence.

A: fed on larvae of Tribolium castaneum.

B : fed on larvae of Chilo suppressalis.

C : fed on larvae of Galleria mellonella.

$\mathrm{O}$ : shows the day not fed. $\mathrm{X}$ : shows the day fed. 


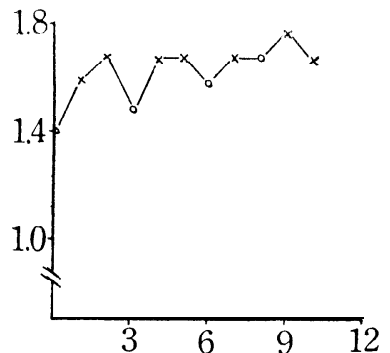

(A)

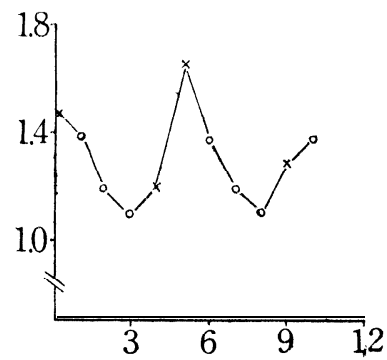

(B)

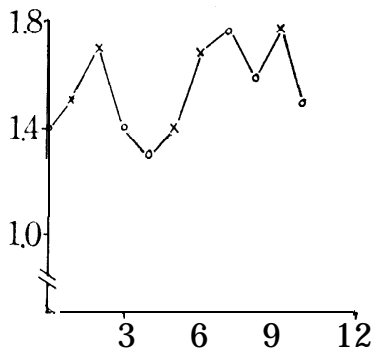

(C)

Fig. 7. Feeding record and body weight change of the adult female

Xylocoris galactinus ; Abscissa, body weight of bug (mg) ; ordinate, days from emergence.

A : fed on larvae of Tribolium castaneum,

B: fed on larvae of Chilo suppressalis.

C: fed on larvae of Galleria mellonella.

0: shows the day not fed, X: shows the day fed.

Table 39. Conversion ratio and predatory value of the adult female Lyctocoris beneficus and Xylocoris galactinus against different food.

\begin{tabular}{|c|c|c|c|c|c|c|}
\hline \multirow{2}{*}{ Prey-predator } & \multicolumn{2}{|c|}{ A } & \multicolumn{2}{|c|}{ B } & \multicolumn{2}{|c|}{ C } \\
\hline & L. & $\mathrm{X}$. & L. & X. & L. & $x$. \\
\hline Initial weight $(\mathrm{mg})$ & 2.3 & 1.5 & 2.3 & 1.5 & 2.2 & 1.4 \\
\hline Final weight (mg) (after 10 days) & 2.6 & 1.4 & 2.8 & 1.6 & 2.7 & 1.7 \\
\hline Increase in weight $(\mathrm{mg})$ & 0.3 & -0.1 & 0.5 & 0.1 & 0.5 & 0.3 \\
\hline Weight food consumed (mg) & 0.8 & 0.3 & 2.1 & 0.9 & 2.4 & 1.2 \\
\hline Conversion ratio $(\%)$ & 25 & -3 & 24 & 11 & 21 & 25 \\
\hline Predatory value mg/ day & 0.12 & 0.03 & 0.19 & 0.09 & 0.24 & 0.12 \\
\hline Number of meals & 7 & 2 & 13 & 5 & 18 & 8 \\
\hline $\begin{array}{l}\text { A : mature larvae of Chilo supp } \\
\text { B : premature larvae of Galleria } \\
\text { C : mature larvae of Tribolium } \\
\text { L: Lyctocoris beneficus. } \\
\text { X: Xylocoris galactinus. }\end{array}$ & $\begin{array}{l}\text { salis. } \\
\text { nellon }\end{array}$ & & & & & \\
\hline
\end{tabular}


The conversion ratio in the adult stage was surely lower than that of nymphal stage in Tribolium-fed groups in both species. Except the Chilo-f ed $\mathrm{X}$. galactinus, the conversion ratio was negatively proportional to the numbers of meals. It coincided with Kasting's opinion that less time for feeding consume less food but made more efficient use of it (Kasting and McGinnis 1959).

\section{Effect of density on feeding habit.}

It is a general conception that population density affects the growth and development of insects, and moderately dense population with abundance of food promotes the growth and food intakes in insects (Pettit 1940, Willis et al. 1958, Feir 1963, McFarlane 1962, etc.). In the present work, to estimate the variation of food intake under different population density conditions, various numbers of adults and 3rd instar nymphs of L.beneficus and X, galactinus were reared in a $100 \mathrm{ml}$ beaker and the daily consumption of food was counted (Tables 40-43).

As Tables 40-43 illustrate, the population density of Anthocorids scarcely influenced the number of Tribolium larvae consumption. Because the body size of Tribolium larvae is so small that one larva is enough to be preyed by one Anthocorid individual at one meal. While the daily food amount consumed in denser population decreased in the groups provided with Chilo and Galleria larvae. But in rough estimation, in gregarious conditions, bugs surely showed better growth and survival than the bug reared in the solitary condition. This conflict may be simply explained by the fact that the bugs prefer to attack inactive prey which was already damaged by another predator. Therefore, many blood sucked larvae died with a number of punctures though other larvae were quite safe. In fact, several

Table 40. Number of prey consumed daily by the adult Lyctocoris beneficus under different population density conditions (in $50 \mathrm{ml}$ beaker).

\begin{tabular}{|c|c|c|}
\hline $\begin{array}{l}\text { No. of bugs } \\
\text { per beaker }\end{array}$ & $\begin{array}{c}\text { Total of consumed } \\
\text { Prey prey per day }\end{array}$ & $\begin{array}{l}\text { No. of daily consumed } \\
\text { prey per predator }\end{array}$ \\
\hline 20 & $\begin{array}{l}\mathrm{T} \\
\mathrm{G}(\text { Tribolium }) \\
\mathrm{C}\end{array}$ & $\begin{array}{l}2.13 \\
0.54 \\
0.28\end{array}$ \\
\hline 10 & $\begin{array}{r}20.8 \\
6.2 \\
3.2\end{array}$ & $\begin{array}{l}2.08 \\
0.62 \\
0.32\end{array}$ \\
\hline 5 & $\begin{array}{l}9.8 \\
3.4 \\
1.8\end{array}$ & $\begin{array}{l}1.96 \\
0.68 \\
0.36\end{array}$ \\
\hline 1 & $\begin{array}{l}2.0 \\
0.8 \\
0.6\end{array}$ & $\begin{array}{l}2.00 \\
0.80 \\
0.60\end{array}$ \\
\hline
\end{tabular}


Table 41. Number of prey consumed daily by the 3rd instar nymph of Lyctocoris beneficus under different population density conditions (in $\mathbf{5 0} \mathrm{ml}$ beaker).

\begin{tabular}{|c|c|c|c|}
\hline $\begin{array}{l}\text { No. of bug } \\
\text { per beaker }\end{array}$ & Prey & $\begin{array}{l}\text { Total of consumed } \\
\text { prey per day }\end{array}$ & $\begin{array}{c}\text { No. of daily consumed } \\
\text { prey per predator }\end{array}$ \\
\hline 20 & $\begin{array}{l}\mathrm{T} \\
\mathrm{G} \\
\mathrm{C}\end{array}$ & $\begin{array}{r}27.2 \\
8.8 \\
\mathbf{4 . 4}\end{array}$ & $\begin{array}{l}1.36 \\
0.44 \\
0.22\end{array}$ \\
\hline 10 & $\begin{array}{l}\mathrm{T} \\
\mathrm{G} \\
\mathrm{C}\end{array}$ & $\begin{array}{r}12.8 \\
4.8 \\
2.4\end{array}$ & $\begin{array}{l}1.28 \\
\mathbf{0 . 4 8} \\
0.24\end{array}$ \\
\hline 5 & $\begin{array}{l}\mathrm{T} \\
\mathrm{G} \\
\mathrm{C}\end{array}$ & $\begin{array}{l}5.6 \\
2.6 \\
1.2\end{array}$ & $\begin{array}{l}1.12 \\
0.52 \\
0.28\end{array}$ \\
\hline 1 & $\begin{array}{l}\mathrm{T} \\
\mathrm{G} \\
\mathrm{C}\end{array}$ & $\begin{array}{l}1.2 \\
0.6 \\
0.2\end{array}$ & $\begin{array}{l}1.20 \\
0.60 \\
0.20\end{array}$ \\
\hline
\end{tabular}

Table 42. Number of prey consumed daily by the adult Xylocoris galactinus under different population density conditions (in $50 \mathrm{ml}$ beaker).

\begin{tabular}{|c|c|c|c|c|}
\hline $\begin{array}{l}\text { No. } \\
\text { per }\end{array}$ & $\begin{array}{l}\text { of bugs } \\
\text { beaker }\end{array}$ & Prey & $\begin{array}{c}\text { Total of consumed } \\
\text { prey per day }\end{array}$ & $\begin{array}{c}\text { No. of daily consumed } \\
\text { prey per predator }\end{array}$ \\
\hline & 20 & $\begin{array}{l}\mathrm{T} \\
\mathrm{G} \\
\mathrm{C}\end{array}$ & $\begin{array}{r}16.6 \\
4.8 \\
4.0\end{array}$ & $\begin{array}{l}0.83 \\
0.24 \\
0.22\end{array}$ \\
\hline & 10 & $\begin{array}{l}\mathrm{T} \\
\mathrm{G} \\
\mathrm{C}\end{array}$ & $\begin{array}{l}8.4 \\
2.4 \\
2.2\end{array}$ & $\begin{array}{l}0.92 \\
0.24 \\
0.22\end{array}$ \\
\hline & 5 & $\begin{array}{l}\mathrm{T} \\
\mathrm{G} \\
\mathrm{C}\end{array}$ & $\begin{array}{l}4.4 \\
1.8 \\
1.0\end{array}$ & $\begin{array}{l}0.88 \\
0.36 \\
0.20\end{array}$ \\
\hline & 1 & $\begin{array}{l}\mathrm{T} \\
\mathrm{G} \\
\mathrm{C}\end{array}$ & $\begin{array}{l}0.8 \\
0.4 \\
0.2\end{array}$ & $\begin{array}{l}0.80 \\
0.40 \\
0.20\end{array}$ \\
\hline
\end{tabular}

bugs were sometimes piercing the body of a single prey at the same time. The active attack by the adult and nymph of $\mathrm{x}$. galactinus on the rice stem borer and Galleria larvae was almost proportional to their gregarious condition. Actually 1 or 2 individuals of bugs were certainly difficult to attack the vulunerable rice stem borer larvae, and they were sometimes smashed to death by the vigorous movement of prey when the bug's stylet pierced the larvae. It is apparent that the adult of L.beneficus which preys approximately upon one borer every two days, is a superior predator against 
Table 43. Number of prey consumed daily by the 3rd instar nymph of Xylocoris galactinus under different population density conditions (in $50 \mathrm{ml}$ beaker).

\begin{tabular}{|c|c|c|c|}
\hline $\begin{array}{l}\text { No. of bugs } \\
\text { per beaker }\end{array}$ & Prey & $\begin{array}{l}\text { Total of consumed } \\
\text { prey per day }\end{array}$ & $\begin{array}{l}\text { No. of daily consumed } \\
\text { prey per predator }\end{array}$ \\
\hline 20 & $\begin{array}{l}\mathrm{T} \\
\mathrm{G} \\
\mathrm{C}\end{array}$ & $\begin{array}{r}10.2 \\
3.6 \\
2.8\end{array}$ & $\begin{array}{l}0.51 \\
0.18 \\
0.14\end{array}$ \\
\hline 10 & $\begin{array}{l}\mathrm{T} \\
\mathrm{G} \\
\mathrm{c}\end{array}$ & $\begin{array}{l}4.8 \\
1.8 \\
1.4\end{array}$ & $\begin{array}{l}0.48 \\
0.18 \\
0.14\end{array}$ \\
\hline 5 & $\begin{array}{l}\mathrm{T} \\
\mathrm{G} \\
\mathrm{C}\end{array}$ & $\begin{array}{l}2.6 \\
1.0 \\
0.6\end{array}$ & $\begin{array}{l}0.52 \\
0.20 \\
0.12\end{array}$ \\
\hline 1 & $\begin{array}{l}\mathrm{T} \\
\mathrm{G} \\
\mathrm{C}\end{array}$ & $\begin{array}{l}0.4 \\
0.2 \\
0.0\end{array}$ & $\begin{array}{l}0.40 \\
0.02 \\
0.00\end{array}$ \\
\hline
\end{tabular}

the rice stem borer, and the third instar nymph of the bug may also become a borer predator to a certain extent. This, of course, indicates the high efficiency of the fourth and fifth instar nymphs as borer predators. The rearing of the first and second instar nymphs of L. beneficus with mature rice stem borers was scarcely successful. In the laboratory condition, these young nymphs were easily reared with larvae of T.castaneum, and in the field condition it is presumably feeding on small sized insects of other creatures. In X. galactinus, the rearing of young instar nymphs with rice stem borer larvae was quite impossible. Only from the fourth instar the nymph can feed on the mature borer larvae, but in this case, high mortality of nymph was observed. In any case, through all the developmental stages, X. galactinus was not an excellent predator in the case of lower population density, while it sometimes showed extremely voracious appetite to rice stem borer larvae when this bug was in gregarious condition.

\section{VT. Phytophagous habit.}

Anthocorid bugs are generally known as predatory insects and including some important natural enemies. However, review of the literature reveals that numbers of observations have been recorded on the phytophagous habit of Anthocorid bugs during the past 90 years. The phytophagous data on the Anthocorid bugs are summarized below in chronological order (Table 44 ):

Although many phytophagous data were recorded, it is a general con- 
Table 44. Phytophagous data of Anthocorid bugs.

\begin{tabular}{|c|c|c|c|}
\hline $\begin{array}{l}\text { Author and year } \\
\text { of publication }\end{array}$ & Anthocorid bug & Host plant & Note \\
\hline McLachlan 1879 & Anthocoris nemorum & hop & \\
\hline McLachlan 1880 & A. nemorum & hop & \\
\hline \multirow[t]{2}{*}{ Theobald 1895} & A. nemorum & hop & \\
\hline & A. confusus & $" 1$ & \\
\hline Reuter 3.908 & Lyctocoris campestris & vegetable & \\
\hline Garman et al. 1914 & Orius insidiosus & corn & \\
\hline Matsumura 1920 & 0. sauteri & mulberry bud & \\
\hline Bodenheimer 1921. & 0. majusculus & chrysanthemum & $\begin{array}{l}\text { The adults suck } \\
\text { the leaves, shoot } \\
\text { and buds, leaving } \\
\text { black scale. }\end{array}$ \\
\hline Prohaska 1923 & A. nemorum & $\begin{array}{l}\text { willow, catkins } \\
\text { and alder bud }\end{array}$ & $\begin{array}{l}\text { common and very } \\
\text { harmful. }\end{array}$ \\
\hline van Poetran 1930 & 0. majusculus & chrysanthemum & \\
\hline Barber 1936 & 0. insidiosus & cotton pollen & \\
\hline Doeksen 1944 & 0. majusculus & maize cobs & $\begin{array}{l}\text { feed on the seeds } \\
\text { through innermost } \\
\text { bract. }\end{array}$ \\
\hline Iglinsky 3.950 & 0. insidiosus & cotton pollen & $\begin{array}{l}\text { male prefer it, } \\
\text { female feed on } \\
\text { spider, mites or } \\
\text { insects. }\end{array}$ \\
\hline Sands 1.951 & A. nemorum & salix & $\begin{array}{l}\text { feed on plant to } \\
\text { some extent. }\end{array}$ \\
\hline Carayon et al. 1959 & 0. pallidicornis & flower pollen & \\
\hline Hill 1961. & A. sarothamni & sap of broom & \\
\hline Dicke et al. 1962 & 0. insidiosus & corn pollen & $\begin{array}{l}\text { principal food of } \\
\text { nymph as well as } \\
\text { adult. }\end{array}$ \\
\hline
\end{tabular}

ception that animal diets were indispensable for the bugs to continue their activity and survival, and especially to keep their reproductive activity, and Hill (1965) pointed out the indispensability of animal diet on the egg production of Anthocoris confusus (Reuter). Additionally, the importance of animal diet on the egg production was also verified on Orius insidiosus (Say) by another worker (Barber 1936). To emphasize this conception, all the rearing data of Anthocorid bugs previously published by many workers are concerned exclusively with animal diet. In Japan, on ly one phytophagous record of the Anthocorid bug was made by Matsumura (1920) on Orius sauteri (Poppius) as an insect pest of mulberry buds. But this record was almost opposed by Esaki and Hashimoto (1955) and predation of leafhopper was demonstrated by the latter workers.

Before the trial of making liberation of L.beneficus and X. galactinus in 
the field as the rice stem borer controlling agents, it is rather important to discuss their influence on the plants if any. Additionally, for the purpose of maintaing the cost for mass production of these bugs under economic level, the study on the reliability of the bugs on the vegetable substance is also indispensable. Because the vegetable substances are in almost all cases less expensive and easier to be handled than animal substances.

At first, the first and third instars and newly emerged adults of both species were reared individually in $3 \times 8 \mathrm{~cm}$ flat bottomed glass tube, providing various substances such as ; 1) dry filter paper, 2) moist filter paper, 3) water soaked uretane foam, 4) sugar solution soaked uretane foam, 5) moist paddy straw, 6) cherry twig, 7) molded cracked corn, and 8) corpse of G. mellonella larvae. The last material was added in this series of test for the purpose of testing the necrophagous habit of the bugs. These substances except the cracked corn were renewed daily and survival of bugs was checked. The observation was conducted with 5-7 individuals in each afforded materials and average longevity is given in Table 45.

Table 45. Longevity of solitary reared Lyctocoris beneficus and Xylocoris galactinus on vegetable diet of different conditions.

\begin{tabular}{|c|c|c|c|}
\hline & $\begin{array}{l}\text { Stage of } \\
\text { bug set }\end{array}$ & L. beneficus & $\begin{array}{l}\text { in days) } \\
X . \text { galactinus }\end{array}$ \\
\hline Dry filter paper & $\begin{array}{l}\text { 1st instar } \\
3 \mathrm{rd} \text { instar } \\
\text { Adult }\end{array}$ & $\begin{array}{l}1.2 \\
1.5 \\
2.1\end{array}$ & $\begin{array}{l}1.3 \\
1.4 \\
1.0\end{array}$ \\
\hline Wet filter paper & $\begin{array}{l}\text { 1st instar } \\
3 \text { rd instar } \\
\text { Adult }\end{array}$ & $\begin{array}{l}3.2 \\
3.1 \\
3.8\end{array}$ & $\begin{array}{l}2.4 \\
2.8 \\
5.1\end{array}$ \\
\hline $\begin{array}{l}\text { Water soaked } \\
\text { uretane foam }\end{array}$ & $\begin{array}{l}\text { 1st instar } \\
3 \text { rd instar } \\
\text { Adult }\end{array}$ & $\begin{array}{l}5.2 \\
12.6(1) \\
27.5\end{array}$ & $\begin{array}{c}3.7 \\
14.3(1) \\
22.2\end{array}$ \\
\hline $\begin{array}{l}\text { Sugar solution soaked } \\
\text { uretane foam }\end{array}$ & $\begin{array}{l}\text { 1st instar } \\
3 \mathrm{rd} \text { instar } \\
\text { Adult }\end{array}$ & 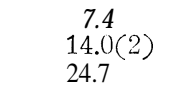 & $\begin{array}{l}5.5 \\
13.2(1) \\
25.8\end{array}$ \\
\hline Moist paddy straw & $\begin{array}{l}\text { 1st instar } \\
3 \mathrm{rd} \text { instar } \\
\text { Adult }\end{array}$ & $\begin{array}{l}5.1 \\
11.4(1) \\
14.2\end{array}$ & $\begin{array}{l}4.2 \\
12.0(2) \\
17.9\end{array}$ \\
\hline Cherry twig & $\begin{array}{l}\text { 1st instar } \\
3 \mathrm{rd} \text { instar } \\
\text { Adult }\end{array}$ & $\begin{array}{l}2.1 \\
4.1 \\
5.2\end{array}$ & $\begin{array}{l}2.4 \\
4.4 \\
7.8\end{array}$ \\
\hline Molded cracked corn & $\begin{array}{l}\text { 1st instar } \\
3 \mathrm{rd} \text { instar } \\
\text { Adult }\end{array}$ & $\begin{array}{l}43.2(3) \\
48.5(3) \\
46.1\end{array}$ & $\begin{array}{l}41.4(3) \\
44.6(3) \\
48.3\end{array}$ \\
\hline $\begin{array}{l}\text { Corpse of larvae of } \\
\text { Galleria mellonella }\end{array}$ & $\begin{array}{l}\text { 1st instar } \\
3 \mathrm{rd} \text { instar } \\
\text { Adult }\end{array}$ & $\begin{array}{l}25.4(3) \\
32.2(3) \\
20.9\end{array}$ & $\begin{array}{l}23.1(3) \\
33.5(3) \\
22.8\end{array}$ \\
\hline
\end{tabular}

Figure in parenthesis shows the frequency of moulting in maximum value. 
As Table 45 shows, water or moisture was an indispensable factor to maintain their lives. In both species, the longer longevity was shown in water soaked uretane foam than moist filter paper. It is probably due to the easier sucking of water in the former materials. Sugar solution showed certain effects to prolong the longevity of both bugs. Although Anderson (1962a) indicated that Anthocoris nemoralis (Fabricius) adult reared with sugar solution had 3 times longer longevity than the individuals reared water only, the present experiment showed that sugar solution did not exhibit such a high nutritional value. Cherry twig was only suited for a oviposition substratum, and the phytophagosity on this plant was scarcely recognized in both species. The bugs reared on moist straw had shorter longevity than the individuals reared on sugar solution. Both molded cracked corn and corpse of G. mellonella larvae had an excellent capacity to maintain the life and restricted developments were observed in these groups. However, the development of the nymph was always much inferior to that of the nymph afforded with animal substances.

To observe the cannibalistic behaviour of bugs, 5 individuals were put together in a tube, and fed with sugar solution, molded cracked corn or corpse of G. mellonella larvae. In this case, cannibalism was observed frequently in both species, and generally only a single individual could survive finally. Cannibalism was frequently occurred at the moulting time, and the individuals just after ecdysis and still keeping soft skin were very often devoured by the other individuals. And the result of the experiment is illustrated in Table 46.

Compared the result of Table 45 with 46, the longevity given in Table 46 was shortened, but the growth was rather accelerated by the improvement of nutritional condition by cannibalism in the majority of cases. Moulting

Table 46. Longevity of gregariously reared Lyctocoris beneficus and $X y l o c o r i s$ galactinus on vegetable diet of different conditions (in maximum value).

\begin{tabular}{|c|c|c|c|}
\hline & \multirow{2}{*}{$\begin{array}{l}\text { Stage of } \\
\text { bug set }\end{array}$} & \multicolumn{2}{|c|}{ Longevity (in days $\mathrm{j}$} \\
\hline & & L. beneficus & X. galactinus \\
\hline Sugar solution & $\begin{array}{l}\text { 1st instar } \\
3 r d \text { instar } \\
\text { Adult }\end{array}$ & $\begin{array}{l}12(1) \\
25(1) \\
32\end{array}$ & $\begin{array}{l}12(2) \\
23(1) \\
18\end{array}$ \\
\hline Molded cracked corn & $\begin{array}{l}\text { 1st instar } \\
3 r d \text { instar } \\
\text { Adult }\end{array}$ & $\begin{array}{l}32(5) \\
31(3) \\
28\end{array}$ & $\begin{array}{l}38(4) \\
42(3) \\
32\end{array}$ \\
\hline $\begin{array}{l}\text { Corpse of larvae of } \\
\text { Galleria mellonella }\end{array}$ & $\begin{array}{l}\text { 1st instar } \\
\text { 3rd instar } \\
\text { Adult }\end{array}$ & $\begin{array}{l}23(4) \\
27(3) \\
\mathbf{3 4}\end{array}$ & $\begin{array}{l}31(5) \\
28(3) \\
\mathbf{2 7}\end{array}$ \\
\hline
\end{tabular}

Figure in parenthesis shows the frequency of moulting. 
was also observed more frequently in this test. A part of the adult female $X$.galactinus reared on the corpse from their third instar laid a few eggs from which the newly hatched nymphs have developed to normal nymphs. The oviposition under an abnormal nutritional condition seemed to exhaust the vitality of the mother, the oviposited female died 1-2 days after the oviposition. It revealed that the Anthocorid bugs were essentially carnivorous insects, and cannibalism between nymphs and adults are often occurred under the animal diet defficient condition, and in the animal material supplying condition, cannibalism seldom occurred. Plant substances were of little value as food sources for both species of bugs. Fungus and the corpse of animal were nutritional but not adequate to accomplish the nymphal growth from the first instar, and its maximum limitation of the development of bugs was only attained to the fourth instar in both species. In cannibalistic bugs a part of the first nymphs developed to the adult. It is nothing but indicating that cannibalism is nutritionally superior to necrophagosity and fungiphagosity. Though in the majority of tested cases the third instar nymphs succeeded to become adults, animal diet was exactly an indispensable material for the fecundity of females. The importance of fungus or corpse as food was only observed in the case of scarce prey. This fact was also proved by the combination tests of copulated males and females which were reared with two different food sources from their fifth instar. In this test males and females were reared singly and a male was supplied to a vial containing one virgin adult female of two day old for one day so as to make a desired couple. (Table 47).

Table 47. Comparison of nutritional effect of fungi and animal diet on the fecundities of Lyctocoris beneficus and Xylocoris galactinus.

\begin{tabular}{|c|c|c|c|}
\hline & $\begin{array}{l}\text { Combination } \\
\text { of pairs }\end{array}$ & $\begin{array}{l}\text { Oviposition } \\
\text { period }\end{array}$ & $\begin{array}{l}\text { No. of eggs } \\
\text { oviposited }\end{array}$ \\
\hline L. beneficus & 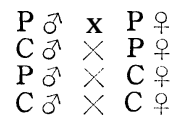 & $\begin{array}{l}\overline{-} \\
25.3 \\
27.1\end{array}$ & $\begin{array}{c}0 \\
0 \\
31.7 \\
32.4\end{array}$ \\
\hline X. galactinus & 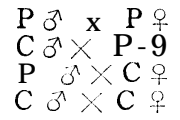 & $\begin{array}{r}\overline{1.5} \\
26.5 \\
24.2\end{array}$ & $\begin{array}{c}0 \\
3.5 \\
31.9 \\
38.4\end{array}$ \\
\hline
\end{tabular}

C : fed with larvae of Tribolium castaneum.

$\mathrm{P}$ : fed with molded cracked corn.

It seems that the lack of animal prey does not influence the reproductive potential of male adult. On the other hand, animal food has a decided influence on the fecundity of female. The animal diet seems to play as another ovipositional stimulant. Namely, the mature female in the oviposition 
stage immediately ceased to oviposit when she was reared in the absence of animal food, even if her ovaries were containing mature eggs. Although Sinha (1961) listed X. galactinus as a fungivorous insect, fungus is a secondary important food for this bug. In conclusion, the feeding habits of $L$. beneficus and $X$.galactinus are almost similar and their frequency of occurrence or preference may be arranged in the following order : Carnivorous> Cannibalistic $>$ Necrophagous $>$ Fungivorous $>$ Phytophagous

Among these feeding habits, only the carnivorous habit can maintain the species from generation to generation.

\section{Effects of food on the fecundity}

It is a well known fact that the fecundity of various insects may be greatly affected by environmental conditions, and Klomp (1964) made a detailed review on this problem. For the factors influencing the fecundity, nutritional condition is also very important, and voluminous studies have been published on this point (Orr 1964, Bracken 1965, Turner et al. 1967, etc.). The works on this problem with carnivorous insects were reviewed by House (1958). Besides, some remarkable works were carried out on Chrysopa carnea Stephen (Hagen 1950, Sundby 1967), Coccinellid beetles (Smith 1965), Anthocorid bugs (Anderson 1962b), etc. In Anderson's work, the effect of prey on the fecundity was illustrated by the length of pre-oviposition stage. He indicates the occurrence of reproductive diapause when the newly emerged adults of some Anthocoris spp. are fed on various prey. For example, Aulacorthum circum-flexum (Buckt.)-fed Anthocoris confusus (Reuter) began oviposition one week after emergence, whereas the pre-oviposition stage prolonged to three weeks when Psylla mali Schid. was offered as food. The effect of food on the egg-production and egg vitality on Coccinellid beetle is presented by Smith (1965). He indicated the indispensability of animal prey for the oviposition of the adult beetles. Also Sundby (1967) pointed out that the artificial media are not enough to make full fecundity on C. carnea, and the addition of the fresh flower (Matricariaindorsa L.) raised the number of produced eggs about three times.

In the present experiment, the fifth instar Lyctocoris beneficus (Hiura) and $X y$ locoris glactinus (Fieber) were reared with larvae of Chilosuppressalis (Walker), Galleria mellonella (Linné) and Tribolium castaneum (Herbst). The pre-oviposition stage, number of produced egg and the rate of egg hatching were estimated as the indices of fecundity of female adults which were gregariously reared in a $50 \mathrm{ml}$ beaker (Table 48). Then the pre-oviposition stage was recorded by the day when the first egg was produced on the corresponding group.

As seen in Table 48, the influence of C. suppressalis, G. mellonella and 7'. castaneum as diet for the bugs showed the same tendency in the fecundity of both L. beneficus and X.galactinus. Namely, the Tribolium-fed bug showed 
Table 48. $\Lambda$ comparison of the influence of food on the fecundity and longevity of the adult Lyctocoris beneficus and Xylocoris galactinus.

\begin{tabular}{|c|c|c|c|c|c|}
\hline & Food & $\begin{array}{l}\text { Pre-oviposition } \\
\text { period(in days) }\end{array}$ & $\begin{array}{l}\text { No. of eggs } \\
\text { per female }\end{array}$ & $\begin{array}{l}\text { Percent of egg } \\
\text { hatching }(\%)\end{array}$ & $\begin{array}{l}\text { Longevity } \\
\text { (in days) }\end{array}$ \\
\hline L. beneficus & $\begin{array}{l}\text { A } \\
\text { B } \\
\text { C }\end{array}$ & $\begin{array}{r}9 \\
28 \\
7\end{array}$ & $\begin{array}{r}18.2 \\
6.1 \\
26.8\end{array}$ & $\begin{array}{l}55.0 \\
34.3 \\
78.6\end{array}$ & $\begin{array}{l}19.4 \\
31.1 \\
28.4\end{array}$ \\
\hline $\mathrm{X}$. galactinus & $\begin{array}{l}\text { A } \\
\text { B } \\
\text { C }\end{array}$ & $\begin{array}{r}9 \\
26 \\
5\end{array}$ & $\begin{array}{r}21.6 \\
8.3 \\
32.1\end{array}$ & $\begin{array}{l}63.3 \\
21.7 \\
83.5\end{array}$ & $\begin{array}{l}21.2 \\
29.0 \\
22.7\end{array}$ \\
\hline
\end{tabular}

A : larvae of Chilo suppressalis.

B : larvae of Galleria mellonella.

$C$ : larvae of Tribolium castaneum.

the highest value both in the egg-production and percent of egg hatching and indicated the shorter pre-oviposition period. The result of Chilo-fed bug was evidently inferior to that of the Tribolium-fed individuals, while the worst result was obtained in the Galleria-fed group. The longer reproductive diapause was observed in the latter two groups. The longevity of adults were in reciprocal proportion to the fecundity.

As to the cause of inferior fecundity in the Chilo- and Galleria-fed bugs, the intake of small amount of food was first considered but the counting of the numbers of pierced scars or punctures on the skins of attacked prey indicated the sufficient feeding by tested predators. Therefore, it is rather conceivable to attribute the cause of inferior fecundity shown by the Chiloand Galleria-fed inidviduals to the nutritional quality or quantity of food, especially of the component of body -fluid.

The review of previous works on the relation between insect fecundity and nutrition shows that the essentiality of some nutritional components are variable with the species of insects. For instance, inorganic salts are required for egg-production in Trypetid flies (Hagen 1958) and D rosophila melanogaster Meigen (Sang and King 1961) but apparently not for Aedesaegypti (Linné) (Sing and Brown 1957, Dimond et al. 1956). Whereas protein and amino acids are unexceptionally essential for the reproduction of all tested insects, and Lea et al. (1956) indicated the importance of total amino acids on the egg-production of mosquitoes.

To evaluate the nutritional value of Galleria and Tribolium larvae on the fecundity of bugs, amounts of free amino acids were quantitatively analyzed. Also to estimate the effect of food on the predators, the amino acids of L. beneficus fed on Galleria or Tribolium larvae were analyzed by the same method. The samples for the amino acid analysis were prepared by the following procedure ; about $200 \mathrm{mg}$ of precisely weighed row 
material were immersed in $60^{\circ} \mathrm{C}$ warm water for 1 minute for the purpose of preventing melanosis, then it was homogenized thoroughly with $80 \%$ ethanol. After the filtration, precipitate was washed for several times with $80 \%$ ethanol. Ethanol was at last extracted by chloroform and water solution of amino acid was condensed in low pressure condition to $\mathbf{0 . 5} \mathbf{m l}$. The ninhydrinpositive compounds were analyzed quantitatively with the automatic amino acid analyzer employing a slight modification of the procedure of Piez and Morris (1960). The results of analysis are given in Table 49.

Table 49. Change of free amino acids contents of Lyctocoris beneficus among various foods $(\mu \mathrm{mol} / \mathrm{g})$.

\begin{tabular}{|c|c|c|c|c|c|c|c|}
\hline Amino acid & $\mathrm{T}$ & G & $\mathrm{T} / \mathrm{G}$ & $\mathrm{TL}$ & GL & $\mathrm{T}-\mathrm{TL}$ & G-GL \\
\hline $\begin{array}{ll}\text { Unknown } & 1^{*} \\
\text { Unknown } & 2^{*} \\
\text { Unknown } & 3^{*} \\
\text { Unknown } & 4^{*} \\
\text { Taurin?* } & \end{array}$ & $\begin{array}{l}0.26 \\
\mathbf{0 . 1 4} \\
\mathbf{0 . 0 4} \\
- \\
0.51\end{array}$ & $\begin{array}{l}0.17 \\
0.35 \\
0.35\end{array}$ & $\begin{array}{l}8.67 \\
\overline{0.24} \\
\overline{1.46}\end{array}$ & $\begin{array}{r}0.37 \\
0.20 \\
\text { trace }\end{array}$ & $\begin{array}{l}0.08 \\
0.09 \\
0.10\end{array}$ & $\begin{array}{c}-0.11 \\
-0.06 \\
-0.04 \\
- \\
-2.40\end{array}$ & $\begin{array}{r}-0.05 \\
-0.09 \\
-0.07 \\
0.35 \\
-0.54\end{array}$ \\
\hline $\begin{array}{l}\text { Urea?* } \\
\text { Methionine suloxide?* } \\
\text { Aspartic acid } \\
\text { Threonine** } \\
\text { Serine }\end{array}$ & $\begin{array}{l}0.13 \\
0.40 \\
0.34 \\
4.45 \\
4.91\end{array}$ & $\begin{array}{l}0.23 \\
1.86 \\
0.10 \\
2.92 \\
1.24\end{array}$ & $\begin{array}{l}0.57 \\
0.22 \\
3.40 \\
1.51 \\
3.96\end{array}$ & $\begin{array}{l}0.11 \\
0.50 \\
0.13 \\
0.88 \\
0.81\end{array}$ & $\begin{array}{l}0.08 \\
0.71 \\
0.13 \\
1.33 \\
0.60\end{array}$ & $\begin{array}{r}0.02 \\
-0.10 \\
0.21 \\
3.57 \\
4.10\end{array}$ & $\begin{array}{r}0.15 \\
1.15 \\
-0.03 \\
1.59 \\
0.64\end{array}$ \\
\hline $\begin{array}{l}\text { Glutamic acid } \\
\text { Proline } \\
\text { Citrulline* } \\
\text { Glycine } \\
\text { Alanine }\end{array}$ & $\begin{array}{r}7.41 \\
9.94 \\
\\
3.96 \\
17.92\end{array}$ & $\begin{array}{l}3.67 \\
4.62 \\
1.60 \\
2.38 \\
5.72\end{array}$ & $\begin{array}{l}2.02 \\
2.15 \\
- \\
1.66 \\
3.13\end{array}$ & $\begin{array}{l}3.72 \\
0.28 \\
- \\
1.03 \\
2.30\end{array}$ & $\begin{array}{l}1.43 \\
1.79 \\
0.32 \\
0.91 \\
2.18\end{array}$ & $\begin{array}{r}3.69 \\
9.66 \\
\\
2.93 \\
15.62\end{array}$ & $\begin{array}{l}2.24 \\
2.83 \\
1.28 \\
1.47 \\
3.54\end{array}$ \\
\hline $\begin{array}{l}\text { Unknown } 5^{*} \\
\text { Valine } \\
\text { Methionine } \\
\text { Isoleucine } \\
\text { Is* } \\
\text { Leucine } \\
\text { L* }\end{array}$ & $\begin{array}{l}- \\
4.56 \\
0.51 \\
1.89 \\
2.87\end{array}$ & $\begin{array}{l}0.14 \\
1.10 \\
0.17 \\
0.41 \\
0.78\end{array}$ & $\begin{array}{l}4.15 \\
3.00 \\
4.61 \\
3.68\end{array}$ & $\begin{array}{c}\text { trace } 0.44 \\
0.18 \\
0.13 \\
0.26\end{array}$ & $\begin{array}{r}\operatorname{trace} \\
0.47 \\
0.08 \\
0.17 \\
0.28\end{array}$ & $\begin{array}{l}- \\
4.12 \\
0.33 \\
1.76 \\
2.61\end{array}$ & $\begin{array}{l}0.14 \\
0.63 \\
0.09 \\
0.24 \\
0.50\end{array}$ \\
\hline $\begin{array}{l}\text { Unknown } 6^{*} \\
\text { Tyrosine } \\
\text { Phenylalanine** } \\
\text { Unknown } 7^{*} \\
\text { Lysine }\end{array}$ & $\begin{array}{r}\operatorname{trace} \\
5.44 \\
1.32 \\
1.01 \\
2.53\end{array}$ & $\begin{array}{l}1.04 \\
0.34 \\
0.32 \\
1.20\end{array}$ & $\begin{array}{l}5.23 \\
3.88 \\
3.16 \\
2.11\end{array}$ & $\begin{array}{r}\operatorname{trace} \\
0.23 \\
0.12 \\
\text { trace } \\
0.38\end{array}$ & $\begin{array}{r}0.54 \\
0.15 \\
\operatorname{trace} \\
0.15\end{array}$ & $\begin{array}{l}- \\
5.21 \\
1.20 \\
1.01 \\
2.15\end{array}$ & $\begin{array}{l}- \\
0.50 \\
0.19 \\
0.32 \\
1.05\end{array}$ \\
\hline $\begin{array}{l}\text { Histidine** } \\
\text { Ammonia } \\
\text { Arginine** }\end{array}$ & $\begin{array}{l}2.87 \\
1.60 \\
2.58\end{array}$ & $\begin{array}{l}2.41 \\
0.31 \\
0.93\end{array}$ & $\begin{array}{l}1.19 \\
5.16 \\
2.77\end{array}$ & $\begin{array}{l}0.49 \\
0.34 \\
1.05\end{array}$ & $\begin{array}{l}0.86 \\
0.30 \\
0.51\end{array}$ & $\begin{array}{l}2.38 \\
1.26 \\
1.53\end{array}$ & $\begin{array}{l}1.55 \\
0.01 \\
0.42\end{array}$ \\
\hline Total of essential amino acids & 23.58 & 8.10 & 2.91 & 3.93 & 4.00 & 19.65 & 4.10 \\
\hline Total of amino acids & 73.50 & 30.63 & 2.40 & 12.43 & 11.95 & 61.07 & 18.68 \\
\hline Grand total & 77.59 & 34.39 & 2.26 & 16.86 & 14.35 & 60.73 & 20.04 \\
\hline \multicolumn{8}{|c|}{$\begin{array}{l}\text { T : larvae of Tribolium castaneum. } \\
\text { G : larvae of Galleria mellonella. } \\
\text { TL : Tribolium- } f \text { ed L. beneficus. } \\
\text { GL : Galleria- } f \text { ed } \text { L. beneficus. } \\
*: \text { calculated by the coefficient of aspartic acid. } \\
* * \text { essential amino acid. }\end{array}$} \\
\hline
\end{tabular}


The interpretation of the results shows that the ninhydrin-positive substance of Tribolium larvae is much more abundant than Galleria larvae, and the ratio of Tribolium/Galleria $(\mathrm{T} / \mathrm{G})$ is 2.26. Further, the ratio becomes more significant when identified amino acids are compared, namely that is 2.40. Although no data are available to discuss the essential amino acids for the Anthocorid bugs, ten following amino acids required by the rat are also essential for the majority of insects (House 1965). They are: arginine, histidine, isoleucine, leucine, lysine, methionine, phenylalanine, threonine, tryptophane and valine. On the other hand, amino acids that are non-essential for rat have been shown to be essential for other insects. According to the literature, the essentiality of the kinds of amino acids differs with the species. Cystine and perhaps glycine are essential for Aedes aegypti (Linné) (Golberg and DeMeillon 1948, Sing and Brown 1957). Alanine, glycine, serine and tyrosine are presumably essential for Agris affinis (Fallen) (House 1954). The essential amino acids on a Coccinellid beetle (Coleomegilla maculata (DeGeer)) were investigated by Atallah and Killebrew (1967) and they recorded 8 essential amino acids. In this case lysine, methionine and tryptophane were not included among the above mentioned 10 essential amino acids but added alanine. The essential amino acids of Rhodnius prolixus (Stål), a Reduviid bug, was studied by Pickett and Friend (1965) and the result is almost coincided with the requirement of rat, except that they added glycine to the essential group. The ratio of $\mathrm{T} / \mathrm{G}$ in these 10 essential amino acids shows 2.91, and the actual amount is $15.48 \mu \mathrm{mol} / \mathrm{g}(23.58-8.10)$. Accordingly the Tribolium larva contains about 3 times of essential amino acids than the Galleria larva, and the amount of each essential amino acid except histidine in the Tribolium larva exceeds twice that of the Galleria larva, especially in valine and isoleucine the ratio was 4.15 and 4.16 respectively. Although the physiological role of these amino acids on insect reproduction still remain unknown, such quantitative difference in the essential amino acids contents may show some suggestions to solve this problem.

Apparent quantitative differences are also obtained in some non-essential amino acids and other ninhydrin positive substances. The superior amount of these substances in the Galleria larvae to the Tribolium larvae is only observed in urea (?), methionine suloxide (?), citrulline (?) or some unknown substances, while the adverse relation are shown in many kinds of material which include all members of identified non-essential amino acids such as : aspartic acid, serine, glutamic acid, proline, glycine, alanine and tyrosine. The amount of these dispensable amino acids in the Tribolium larva is $49.92 \mu \mathrm{mol} / \mathrm{g}$ and that of Galleria larva is only 18.77. Among these amino acids, alanine which is recognized to be a very important amino acid in Blattella and Agria sp. by Hilchey (1953) and House (1954) respectively is significantly abundant in the Tribolium larva, being $\mathbf{1 7 . 9 2} \mu$ 
$\mathrm{mol} / \mathrm{g}$ and it occupies about $23.2 \%$ of the total amino acids, and that of Galleria larva is only $5.72 \mu \mathrm{mol} / \mathrm{g}$ and $18.7 \%$. T/G value of these amino acids always exceeds 2 except glycine, but 1.66 even in glycine. The importance of amount of dispensable amino acids as the supplement to the essential ones for normal growth, development or egg-production is postulated by several workers (Ishii and Hirano 1955, Lea et al. 1956). For instance, alanine, glycine, serine and tyrosine in A.affinis, and hydroxyproline, proline and serine in $A$. aegypti are not essential for the growth and development, but a significant retardation occurs when any one of them is lacking (House 1954, Sing et al. 1957).

Some qualitative differences are also observed between these 2 samples which contain such unknown substances 2, 4, 5, 6 and citrulline (?). But the discussion of these substances upon the fecundity is of course impossible unless the nature of these substances are not identifled. The presence of citrulline in the body fluid was previously reported by Chu (1962a, b) in the Papilio larvae, but the physiological function of this amino acid is still unknown. However, Hinton et al. (1951) and DeGroot (1953) reported the partly replacement to arginine, an essential amino acid in Drosophila melanogaster Meigen and Apis mellifera Linné respectively.

The amount of ninhydrin-positive substances, total amino acids and essential amino acids of L. beneficus are surely lower than those of the prey. There are little qualitative variations on the ninhydrin-positive substances of L.beneficus reared on different prey. The only significant qualitative difference is the presence of citrulline (?) in the Galleria-fed bug and this amino acid is only detected in the Galleria larva but not in T.castaneum. The apparent quantitative variations of amino acids are rather observed in some components, for instance ; amounts of taurin (?), glutamic acid, methionine, lysine and arginine. And such components are surely prevalent in the Tribolium-fed individuals, but a reverse tendency is seen in proline, tyrosine and histidine. Generally speaking, the composition of amino acids in predators is not decidedly influenced by food both in qualitatively and quantitatively. While the discrimination of amino acid amount between the prey and predator is seemed to be an important key to solve this problem. That is, for example, in the Tribolium-fed bug can convert $15.62 \mu$ mol. of alanine but only $3.54 \mu \mathrm{mol}$. in the Galleria-fed individuals. A similar tendency is observed in all identified amino acids including 9 essential amino acids. The value of T-TL/G-GL are evidently significant both in the amount of ninhydrin-positive substances and total amino acids which are about 3.0 and 3.3 respectively. While the ratio, 4.8, is more significant when the amount of essential amino acids is compared. This may indicate that the Tribolium-fed bugs are afforded with about 3 times of amino nitrogen than the Galleria-f ed individuals, and the value of T-TL/G-GL raises up to 4.8 times when the essential amino acids are only compared. There- 
fore, in the Tribolium-fed bugs, they are able to convert more essential nitrogen source for reproductive use. And it is worth to notice that argini.ne, isoleucine, leucine, lysine, phenylalanine, threonine, tryptophane and valine were already proved as the essential amino acids for the egg-production of certain insects (Greenberg 1951, Dimond. et al. 1956, Lea et al. 1956).

At the moment we have few available data relating to the function of individual amino acid on the insect fecundity. It is difficult to continue the present discussion. To make a more accurate study on this point, it is at least indispensable to rear bugs with certain amino acid difficient diet and compare its fecundity. Moreover, the nutritional factor affecting the insect fecundity is not restricted to amino acid only. To clear this problem, further studies should be conducted with other nutrients and by another biochemical method.

For the next step, some works on the lipid and its component should be referred. Because it is a general conception that the Galleria larva is more abundant in lipid content than the Tribolium larva. In addition, some evidences of the importance of certain fatty acids in the nutrition of some insect species have been reported on Argyrotarnia velutinana (Walker), Carpocapsa pomonella (Linné), and Anthonomus grandis Boheman (Rock et al. 1965, Rock 1967, Earle et al. 1967). Also a review on the nutritional requirement bv insects is compiled by Fast (1964). On the other hand, the nutritional invalidity of fatty acids on the larvae of Chilosuppressalis is also reported bv Hirano(1963), and he also indicated the growth inhibiting activity of these compounds at higher dosages.

The total lipid content of the larvae of $\mathbf{G}$. mellonella and T. castaneum were extracted by the Soxhlet apparatus, almost following the initial steps of the procedure of Ascher and Neri (1961): The larvae were ground in a mortar with twice their weight of anhydrous $\mathrm{Na}_{2} \mathrm{SO}_{4}$, the mixture was left for one hour in a covered mortar and was then transferred quantitatively into a filter paper cylinder for Soxhlet extraction. The larvae were first extracted with ether for 15 hours, after which the vessel with ether was exchanged for one with acetone. Re-extraction of the package with acetone was then continued for another 10 hours. The greater part of the solvent was distilled off on the water bath, then dried in vacuum exsiccators over $\mathrm{CaCl}_{2}$ and further continued to dry until the solid paraffin wax weight became constant.

The result of extraction shows significant abundance of lipid in the Galleria larvae, being $0.22 \mathrm{~g}$ per $1 \mathrm{~g}$ of wet material and that of the Tribolium larvae was only $0.04 \mathrm{~g}$. The nature of the extracts are also very different, the sample from Galleria is bright yellow coloured and that of Tribolium is dark brown green.

Paper chromatographic separation was employed to separate some comyonents on the hexane solution of these et her-aceton e extracts. The separa- 
tion was carried out with Tōyo No. 51 filter paper in ascending method. The mixture of white kerosene and xylene (4:1 v/v) was used as a solvent. When the solvent had travelled a distant of $35 \mathrm{~cm}$ from the spotted point, the chromatogram was removed from the chamber. The colour development procedure was followed by Viswanathan and Meera (1962) : Thus, the chromatogram was at first washed twice in tap water to remove the solvent. It was then kept immersed for $15 \mathrm{~min}$. in a $0.1 \%$ mercuric acetate solution containing $0.5 \mathrm{ml}$ of acetic acid per litre. Excess mercuric acetate was removed by washing the chromatogram in removing tap water for $45 \mathrm{~min}$. The chromatogram was air dried, then sprayed with

Frontal line

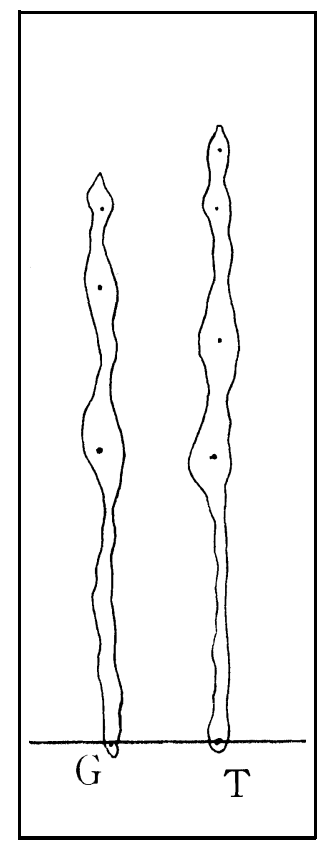

Fig. 8. Diagram showing chromatographic patterns produced by paper chromatography of lipoid content of ether-acetone extract of Tribolium larvae (T) and Galleria larvae (G).
$0.2 \%$ solution of S-dipheny.l carbazide in 95\% ethanol.

Although the separation was almost failed, the long purple coloured bands were observed in both samples. Then the top of the band in the Tribolium larvae was extended to the point of $\mathrm{R}_{\mathrm{f}} 0.86$ and that of Galleria was ceased at 0.78 . In the Tribolium sample, 4 significant purple colour concentrations were recognized and they were placed at the points of $0.92,0.75$, 0.55 and 0.42 of $R_{f}$ value. In another sample, only 3 spots appeared and their $\mathrm{R}_{\mathrm{i}}$ value were $0.73,0.62$ and 0.42 (Fig. 8). As the inferiority of chromatographic separation, no further work on the identification was made on these samples. But it is apparent that the composition of ether acetone extracts is different from each other.

The studies on the lipid and fatty acid in the Galleria larvae was conducted by Young $(1964,1967)$. And his latter paper identified 6 fatty acids from the chloroform-methanol extract of the larvae (Table 50). The result of his analysis indicates the abundance of 2 fatty acids of 16 carbons and 18 carbons with 1 double bond. For the former compound,

Table 50. Fatty acids of larvae of Galleria mellonella (After Young 1967)

\begin{tabular}{ccccccc}
\hline No. of carbon in fatty acid & 14 & 16 & $16^{1=}$ & 18 & $18^{1=}$ & $18^{2=}$ \\
percent by weight & trace & 39.6 & 2.9 & 3.1 & 47.2 & 6.5 \\
\hline
\end{tabular}


palmitic acid is corresponded. And oleic and elaidic acids etc. belong to the latter group (Table 49).

It is a noticeable fact that the growth of Gryllodes sigillatus (Walker) is inhibited by the existence of some fatty acids and their methyl ester, including the methyl ester of oleic acid and palmitic acid. Above all, inhibiting action is very significant in methyl palminate (McFarlane and Henneberry 1965). Although the inhibiting action was tested with the use of a compound absorbed filter paper in a cricket rearing cage in their experiment, and not by feeding test, it is possibly conceivable that these fatty acids also show some inhibiting actions when they are taken into the digestive organs of insects. However, a question still exists that whether these fatty acids show any growth inhibition activity on the growth of Anthocorid bugs as in the case of G. sigillatus. In addition, Hirano (1963) indicates the inhibiting action for the growth of rice stem borer of oleic acid and linoleic acid $\left(\mathrm{C}^{2 *}\right)$, in the presence of higher dosages in the diet of the borer. Because of the lack of an available datum, the author can not make any discussion on the fatty acid of the Tribolium larvae.

\section{Rearing with artificial media}

The review of previous works reveals that the rearing of suctorial insects with artificial diets was already established in some aphids, leafhoppers and Heteropterous bugs. The first work on the Heteropterous bug was attempted by Scheel et al. (1957) on Oncopeltus fasciatus (Dallas) and Euschistus variolarius (Palisot de Beauvois). Since then, the works on these bugs were also made by Beck et al. (1958) and Scheel et al. (1958). The studies on another Bug, Lygus hesperus Knight, have been published by Lands and Strong (1965), Auclair and Raulston (1966) and Vanderzant (1967), and the last author succeeded to rear both L. hesperus and L. lineolarius (Palisot de Beauvois) with artificial diet up to the stage of oviposition. Anyway, such works have been confined chiefly to the phytophagous bugs. On the other hands, Bronnimann (1964) succeeded the rearing of Rnthocoris nemorum (Linné) and A.nemoralis (Fabricius) from the first instar to the adult stage with sweetened condensed milk. However, these Anthocorids failed to produce eggs unless some animal diets were not supplied in their adult stage. This may be the only work on the rearing of predacious bug with artificial media. The same trials on the other groups of predacious insects have been conducted on Chrysopa carnea Stephen (Hagen and Tassen 1965, 1966, Sundby 1967) and Coccinellid beetles (Smirnoff 1958, Smith 1960, Tanaka and Maeta 1965, Atallah and Newson 1966). Although the oviposition of Chrysopa female which was reared with artificial diet was observed without exception, the addition of animal diets was almost an indispensable procedure to the majority of Coccinellid beetles. Otherwise, the beetles did not lay their eggs. 
Presumably the only successful trial on artificial diets was obtained with Coleomegilla maculata DeGeer by Atallah and Newson (1966) who added some liver fractions and the extract of cotton leaves into the media. But in some other species of lady beetles the oviposition did not occur when fed with this medium.

The study on the rearing of Lyctocoris beneficus (Hiura) and Xylocoris galactinus (Fieber) with artificial media was at first begun with the selection of suitable rearing methods and the principal chemical components of media solution. As to the first point, 4 following methods were preliminary compared.

I) Bronnimann's straw method (Bronnimann 1964) : That is, a thin twist of

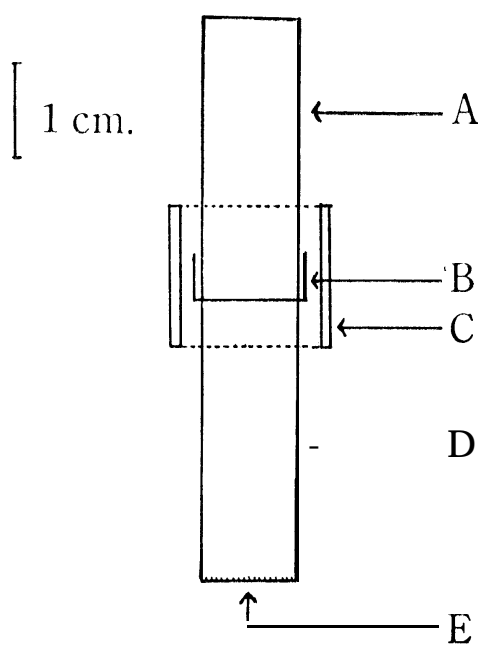

Fig. 9. Rearing apparatus for para film method.

A : glass vial (media container).

B : stretched parafilm.

C : polyvinyl tube.

I> : glass tube (bug adaptorj.

E : organdy cloth. cotton wool dipped in the media was drawn through a plastic drinking straw by means of a fine wire. The straw containing the media was then cut into pieces of certain length after the refrigeration to solid.

2) Hagen's paraffin-covered droplet method (Hag-en and Tassen 1965) : At first $40 \mathrm{ml}$. of media solution was mixed with $0.2 \mathrm{~g}$ paraffin $\left(\mathrm{mp} .45^{\circ} \mathrm{C}\right)$ in a $50 \mathrm{ml}$ beaker and the mixture was heated to about $60^{\circ} \mathrm{C}$, then the paraffin forms thin layer on the surface of the solution. Droplets were made by dipping into the warm mixture with a glass applicator rod which was lifted out and gently touched to a piece of parafilm.

3) Ouchi's parafilm method (Ouchi 1967): The structure of the apparatus in this method is illustrated in Fig. 9, that is mainly composed of a glass tube and a glass vial both of which are $1 \times 3 \mathrm{~cm}$ in diameter and height respectively. The tube was used for the bug adaptor, and its bottom was covered with a sheet of organdy cloth. The cloth side of vial was used for the container of media solution and the openning was covered with a stretched parafilm after the solution was provided. Then the parafilm covered opening of the vial and the uncovered end of the tube were connected with a piece of polyvinyl tube. Thus the bugs in the adaptor can take the media solution by piercing the film with proboscis.

4) Uretane foam method: This is simply prepared by the soaking of a piece of uretane foam which was cut to about $1 \mathrm{~cm}^{3}$ with a media solution. 
For the media solution, 4 following formulations were preliminary compared.

Diet A. (after Bronnimann 1964)

sweetened condensed milk $+\mathrm{H}_{2} \mathrm{O}(2: 1 \mathrm{v} / \mathrm{v})$

Diet B. (after Hag-en and Tassen 1965)

$\begin{array}{lc}\text { enzymatic protein hydrolysate of yeast } & 10.0 \mathrm{~g} \\ \text { enzymatic protein hydrolysate of casein } & 10.0 \mathrm{~g} \\ \text { fructose } & 17.5 \mathrm{~g} \\ \text { ascorbic acid } & 2.0 \mathrm{~g} \\ \text { choline chloride } & 25.0 \mathrm{mg} \\ \text { water } & 100 \mathrm{ml}\end{array}$

Diet C. (modified Beck et al. 1958)

soluble starch

dextrose

$2.0 \mathrm{~g}$

sodium caseinate

$2.0 \mathrm{~g}$

beef extract

$2.0 \mathrm{~g}$

$2.0 \mathrm{~g}$

Brewer's yeast powder

$4.0 \mathrm{~g}$

cholesterol acetate

$0.1 \mathrm{~g}$

Wassen's salt

$0.1 \mathrm{~g}$

water

$100 \mathrm{ml}$

Diet D. (modified Scheel et al. 1957)

dextrose

$2.0 \mathrm{~g}$

soluble starch

$2.0 \mathrm{~g}$

sodium caseinate

$2.0 \mathrm{~g}$

Brewer's yeast powder

$2.0 \mathrm{~g}$

beef extract

$0.5 \mathrm{~g}$

Wassen's salt

$0.2 \mathrm{~g}$

cholesterol

$80.0 \mathrm{mg}$

water

$100 \mathrm{ml}$

To select the suitable methods and formulations, 10 first instar $X$. galactinus were reared separately by the above mentioned methods and with the above cited formulations, and the longevity of nymphs was recorded for 10 days (Table 51). In the rearing experiments 1,2 and 4 , all nymphs were reared in a flat-bottomed glass tube, sized $2.5 \times 8 \mathrm{~cm}$ (diameter $\times$ height), and the tube was covered with cork stopper. The medium was renewed every day.

As seen in Table 51, it is apparent that the fourth method, namely the uretane foam method, was the best and the parafilm method followed. In the latter method, the death of majority of nymphs was caused by the drowing in the solution flown from the leakage of parafilm which occurred most frequently when the diluted milk medium was provided. 
Table 51. Longevity of the first instar Xylocoris galactinus reared with 4 kinds of artificial diets by 4 kinds of rearing methods (started with 10 individuals).

\begin{tabular}{|c|c|c|c|c|c|c|c|c|c|c|c|}
\hline \multirow{2}{*}{$\begin{array}{l}\text { Rearing } \\
\text { method }\end{array}$} & Diet & \multicolumn{10}{|c|}{ No. of nymphs survived in days } \\
\hline & No. & 1 & 2 & 3 & 4 & 5 & 6 & 7 & 8 & 9 & 10 \\
\hline \multirow{4}{*}{1} & A & 6 & 4 & 3 & 2 & 0 & - & - & - & - & - \\
\hline & $\mathrm{B}$ & 7 & 2 & 2 & 0 & - & - & - & - & - & - \\
\hline & $\mathrm{C}$ & 5 & 3 & 2 & 2 & 0 & - & - & - & - & - \\
\hline & $\mathrm{D}$ & 6 & 4 & 3 & 1 & 0 & & - & - & - & - \\
\hline \multirow{4}{*}{2} & A & 5 & 3 & 2 & 0 & - & - & - & - & - & - \\
\hline & $\mathrm{B}$ & 6 & 4 & 3 & 3 & 1 & 0 & - & - & - & - \\
\hline & C & 7 & 2 & 1 & 0 & - & - & - & - & - & - \\
\hline & $\mathrm{D}$ & 5 & 1 & 1 & 1 & 1 & 0 & - & - & - & - \\
\hline \multirow{4}{*}{3} & A & 5 & 4 & 3 & 3 & 3 & 3 & 3 & 3 & 3 & 2 \\
\hline & B & 7 & 6 & 6 & 6 & 6 & 5 & 5 & 5 & 5 & 5 \\
\hline & C & 6 & 6 & 6 & 5 & 5 & 5 & 5 & 5 & 4 & 4 \\
\hline & $\mathrm{D}$ & 8 & 7 & 7 & 6 & 6 & 6 & 5 & 5 & 5 & 5 \\
\hline \multirow{4}{*}{4} & A & 10 & 10 & 9 & 9 & 7 & 7 & 7 & 7 & 7 & 7 \\
\hline & B & 9 & 9 & 9 & 8 & 8 & 8 & 8 & 8 & 8 & 8 \\
\hline & C & 10 & 10 & 8 & 8 & 7 & 5 & 4 & 4 & 4 & 3 \\
\hline & D & 10 & 10 & 10 & 9 & 9 & 8 & 8 & 7 & 7 & 7 \\
\hline
\end{tabular}

Although parafilm method is surely a time-consuming work, it may become one of the ideal technique to evaluate the nutritional requirement of bugs when membrane is improved to a more tenacious material. The lowest mortality obtained in the uretane foam method was partly due to the contamination of mold on the wall of glass tube. Because, as previously mentioned, the bugs are facultatively fungivorous, and undoubtly the fungus may play some nutritional role to some extents on the development of bugs. However, it is not a suitable method to study nutritional requirement of bugs because of the heavy fungi-infection, but may be used as the most effective method for the practical rearing. Both the first and second rearing methods were not advisable for this bug. In the first method, the cotton thread entangled the legs of bugs and this caused the death of all the nymphs. In the second method, high mortality is assumed to be caused by the difficulty of sucking solution through a paraffin membrane. As to the formulation of media, diet $\mathrm{C}$ was somewhat inferior, at least on the survival of the nymph, and no significant superiority was observed among 3 tested formulations. Therefore, the further work was concentrated to the uretane foam method with diets A, B and D on both species of bugs.

Rearing results of newly hatched nymphs and the thrid instars of L.beneficus and $X$.galactinus with the formulations A, B and D were presented in Table 52. In this experiment, the nymphs were reared separately in a flatbottomed glass tube as in the case of the preceding experiment. 
Table 52. Growth of Lyctocoris beneficus and Xylocoris galactinus fed with artificial diets ( 25 individuals per each test).

\begin{tabular}{|c|c|c|c|c|c|}
\hline \multirow{2}{*}{$\begin{array}{l}\text { Diet } \\
\text { No. }\end{array}$} & \multirow{2}{*}{$\begin{array}{l}\text { Instar } \\
\text { set }\end{array}$} & \multicolumn{2}{|c|}{ No. of nymphs to adult } & \multicolumn{2}{|c|}{ Avg days to adult } \\
\hline & & L. beneficus & X. galactinus & L. beneficus & $\bar{X}$. galactinus \\
\hline A & $\begin{array}{l}1 s t \\
3 r d\end{array}$ & $\begin{array}{r}9 \\
21\end{array}$ & $\begin{array}{r}5 \\
19\end{array}$ & $\begin{array}{l}32.4 \\
23.7\end{array}$ & $\begin{array}{l}22.4 \\
13.4\end{array}$ \\
\hline B & $\begin{array}{l}1 s t \\
3 r d\end{array}$ & $\begin{array}{r}7 \\
19\end{array}$ & $\begin{array}{r}7 \\
19\end{array}$ & $\begin{array}{l}33.8 \\
24.1\end{array}$ & $\begin{array}{l}24.8 \\
14.7\end{array}$ \\
\hline D & $\begin{array}{l}1 s t \\
3 r d\end{array}$ & $\begin{array}{l}12 \\
23\end{array}$ & $\begin{array}{l}1.5 \\
22\end{array}$ & $\begin{array}{l}30.9 \\
21.2\end{array}$ & $\begin{array}{l}19.3 \\
14.2\end{array}$ \\
\hline $\mathrm{CK}^{*}$ & $\begin{array}{l}1 s t \\
3 r d\end{array}$ & $\begin{array}{l}18 \\
24\end{array}$ & $\begin{array}{l}21 \\
25\end{array}$ & $\begin{array}{l}26.3 \\
19.1\end{array}$ & $\begin{array}{l}16.2 \\
12.4\end{array}$ \\
\hline
\end{tabular}

* reared with larvae of Tribolium castaneum.

It is evident that the diet $\mathrm{D}$ was the best one tested so far as the longevity and developmental rate of both species were concerned, and diet $\mathrm{B}$ showed the worst result. The rearing of the first instar nymphs was much inferior both in longevity and developmental rate to that of the rearing from the third instar. In the rearing of first instar nymphs, almost all the tested individuals died in the fourth or fifth instar. If comparison was made on the development between the nymphs which were reared with artificial media and fed with animal diets, the prolongation of nymphal stage in the former group was exclusively pronounced during the fifth instar. The rearing of nymphs with artificial media from the third instar was almost successful on all diets. However, some delay of development was observed. Although no detailed data were available, the addition of animal prey to the third instar nymphs which had been reared with artificial media from the first instar was very helpful to accomplish the normal development in the later nymphal stage. The copulation was normally observed in both species when they were reared under gregarious condition, but no eggs were deposited at all.

To examine the nutritional value of artificial media on adult bugs, 2 day old fertile females which were fed with animal prey during their nymphal stages were reared with diets A, B and D. And the pre-oviposition period and the number of oviposited eggs were recorded (Table 53). However, some individuals did not deposite any eggs at all. The minimum value of pre-oviposition period was given in the same table.

As seen in Table 53, the adult bugs laid eggs except the bug group of L.beneficus which was fed with diet B. But the egg production was evidently inferior to groups which were fed with animal diets. Although diet D showed the best result in both species among the 3 formulations tested, the egg production ability was less than one-third of the bug fed with animal 
Table 53. Number of eggs laid by a female L. beneficus or X. galactinus reared with artificial media in her adult stage.

\begin{tabular}{|c|c|c|c|}
\hline Bug & Diet & $\begin{array}{l}\text { Pre-oviposition } \\
\text { period(in days }\end{array}$ & $\begin{array}{l}\text { No. of eggs/female } \\
(\text { min-aver-max })\end{array}$ \\
\hline L. beneficus & $\begin{array}{c}\mathrm{A} \\
\mathrm{B} \\
\mathrm{D} \\
\mathrm{CK}\end{array}$ & $\begin{array}{l}8 \\
- \\
9 \\
8\end{array}$ & $\begin{array}{c}\text { O-4.2-10 } \\
0 \\
\text { O-12.3-24 } \\
1.2-38.7-52\end{array}$ \\
\hline X. galactinus & $\begin{array}{l}\mathrm{A} \\
\mathrm{B} \\
\mathrm{J}) \\
\mathrm{c} \mathrm{K}\end{array}$ & $\begin{array}{l}4 \\
5 \\
5 \\
4\end{array}$ & $\begin{array}{c}\text { O-3.4-8 } \\
0-0.3-2 \\
8-14.4-25 \\
12-48.3-67\end{array}$ \\
\hline
\end{tabular}

* minimum value.

diets. Although no difference was observed on the length of pre-oviposition period between the individuals fed with animal diets and artificial media, the oviposition period was much shorter in the individual groups fed with artificial media, and even the maximum oviposition period lasted for 3 days. On the contrary, in the individual groups fed with animal food, the oviposition period lasted for more than 20 days in both species.

As Tables 52 and 53 indicate, diet $\mathrm{D}$ is the most promising formulation among the 4 tested media. As the next step, the improvement of dietal component was tried with this medium. In Table 54, the modification of diet $\mathrm{D}$ was given. In this case, the addition of enzymatic protein hydrolysate of casein, ascorbic acid, choline chloride and cholesterol acetate to the diet seemed prospective, but the addition of these materials to the formulation caused precipitation.

The comparison of rearing experiments with these diets was conducted by using the first and third instar L.beneficus and X. galactinus (Table 55).

Table 54. Improved diets of D for Lyctocoris beneficus and Xylocoris galactinus (in $\mathrm{g} / 100 \mathrm{ml}$ water).

\begin{tabular}{|c|c|c|c|c|c|c|}
\hline & \multicolumn{6}{|c|}{ Diet No. } \\
\hline & $1^{*}$ & 2 & 3 & 4 & 5 & 6 \\
\hline Dextrose & 2 & 2 & 2 & 2 & 2 & 2 \\
\hline Soluble starch & 2 & 2 & 2 & 2 & 2 & 2 \\
\hline Sodium caseinate & 2 & 2 & 2 & 2 & 2 & 2 \\
\hline Beef extract & 0.5 & 1 & 1.5 & 3. & 1 & 1 \\
\hline Cholesterol & 0.08 & 0.08 & 0.08 & 0.08 & 0.08 & 0.08 \\
\hline Wassen's salt & 0.2 & 0.2 & 0.2 & 0.2 & 0.2 & 0.2 \\
\hline Brewer's yeast powder & 2 & 2 & 2 & 2.5 & 3.0 & 3.5 \\
\hline
\end{tabular}


Table 55. Growth of Lyctocoris beneficus and Xylocoris galactinus fed with improved diet $\mathrm{D}$.

\begin{tabular}{|c|c|c|c|c|c|}
\hline Diet & Instar & Percent emerge & ce of adult $(\%)$ & Avg no. o & days to adult \\
\hline & set & L. beneficus & $X$. galactinus & L. beneficus & $X$. galactinus \\
\hline D -1 & 1 st & 28 & 24 & 31.5 & 21.8 \\
\hline & $3 \mathrm{rd}$ & 64 & 64 & 21.2 & 14.0 \\
\hline$D-2$ & 1 st & 56 & 36 & 28.4 & 17.8 \\
\hline & $3 \mathrm{rd}$ & 72 & 72 & 20.4 & 12.8 \\
\hline D-3 & $1 \mathrm{st}$ & 24 & 16 & 32.4 & 19.2 \\
\hline & $3 \mathrm{rd}$ & 60 & 64 & 22.8 & 13.2 \\
\hline D-4 & $1 \mathrm{st}$ & 36 & 24 & 33.6 & 21.8 \\
\hline & $3 \mathrm{rd}$ & 64 & 56 & 21.3 & 13.0 \\
\hline D-5 & $1 \mathrm{st}$ & 44 & 28 & 29.4 & 21.3 \\
\hline & $3 \mathrm{rd}$ & 56 & 60 & 22.6 & 14.8 \\
\hline D-6 & $1 \mathrm{st}$ & 28 & 20 & 31.0 & 22.4 \\
\hline & $3 \mathrm{rd}$ & 58 & 68 & 22.8 & 15.6 \\
\hline
\end{tabular}

Although the results showed no noticeable difference among the diets, a slight improvement was observed in diet D-2. But all of these diets were not effective to promote the reproductive potencial of adults.

The analysis of amino acids in the larvae of Tribolium castaneum(Herbst) and Galleria mellonella (Linné) suggests the importance of amino acid amount in food for the egg production of bugs. In the experiments shown above, the protein emphasized mdia, namely diets D-2 and D-3, were scarcely effective in the promotion of both growth and fecundity, and even the rearing result of D-4 was inferior to that of D-l. Presumably it is partly ascribed to the difficulty in sucking the media solution by nymphs due to the high viscosity of media which occurred by the excess amounts of beef extracts.

The prevention of cannibalism is an another important factor to decide the practical value of artifical media especially in the mass rearing of predatory insects. Although cannibalistic behaviour was rarely seen in L.beneficus and $X$.galactinus in the presence of sufficient animal food, the occurrence of cannibalism was already demonstrated only in the case of deficiency of animal diets (cf. phytophagous habit). To examine the cannibalism in the rearing condition of artificial media, 10 of the third instar nymphs were reared gregariously in a $50 \mathrm{ml}$ beaker provided with artificial media and the number of survived bugs was recorded (Table 56).

The results of experiments showed very violent cannibalism between the individuals, and in most cases, about half of tested individuals were annihilated within 2 days. After 10 days, generally only a single bug survived. And in almost all cases the cannibalistic phenomenon occurred during the moulting process or just after the ecdysis when the integument 
Table 56. Survival of Lyctocoris beneficus and Xylocoris galactinus reared gregariously with artificial media (started with 10 3rd instar nymphs, average of 5 tests).

\begin{tabular}{|c|c|c|c|c|c|c|}
\hline & $\begin{array}{l}\text { Diet } \\
\text { No. }\end{array}$ & $\begin{array}{l}\mathrm{N} \\
2\end{array}$ & $\begin{array}{c}\text { su } \\
4\end{array}$ & $d{ }_{6}^{d}$ & $\begin{array}{c}\text { after } \\
8\end{array}$ & $\begin{array}{l}\text { days } \\
10\end{array}$ \\
\hline L. beneficus & $\begin{array}{l}\text { D-1 } \\
\text { D-2 } \\
\text { D-6 }\end{array}$ & $\begin{array}{l}3.6 \\
5.0 \\
3.4\end{array}$ & $\begin{array}{l}2.2 \\
3.2 \\
2.8\end{array}$ & $\begin{array}{l}1.6 \\
2.6 \\
2.0\end{array}$ & $\begin{array}{l}1.4 \\
2.2 \\
2.0\end{array}$ & $\begin{array}{l}1.2 \\
1.4 \\
0.8\end{array}$ \\
\hline$X$. galactinus & $\begin{array}{l}\text { D-1 } \\
\text { D-2 } \\
\text { D-6 }\end{array}$ & $\begin{array}{l}5.0 \\
\mathbf{5 . 2} \\
4.8\end{array}$ & $\begin{array}{l}3.8 \\
4.4 \\
4.4\end{array}$ & $\begin{array}{l}1.8 \\
3.0 \\
2.2\end{array}$ & $\begin{array}{l}1.6 \\
2.2 \\
1.8\end{array}$ & $\begin{array}{l}1.2 \\
1.6 \\
1.0\end{array}$ \\
\hline
\end{tabular}

of body was not completely sclerotized. Although the diet D-2 wasvery slightly preferable, it was still not practical for the mass rearing of bugs.

The addition of vitamin E (alpha-tocopherol) into the diet of some insect artificial media was attempted by several workers (Fraenkel and Blewett 1946, Beck et al. 1949, Vanderzant 1957, etc.). But according to several workers, its nutritional requirement in insects has not yet been recognized (Trager 1953, House 1962, Gilmour 1961, Dadd 1963, etc.). On the other hand, the improvement of the growth, especially of reproductive potential, has been proved in some insects such as : Cryptolaemus montrouzieri Mulsant, Achetadomesticus (Linné), Agria affinis (Fall\&), Exeristes comstockii (Cresson), etc. (Chumakova 1962, Meikle and McFarlane 1965, House 1966, Bracken 1966 respectively). As seen in the above works, the rearing of bugs with an artificial medium is not superior to that with animal diets both in growth and survival, and this defect is especially significant because of the decrease of reproductive potential. To compensate this defect the addition of vitamin $\mathrm{E}$ was attempted to the artificial media. Thus, 0.5, 1,2 and $4 \mathrm{mg}$ of vitamin $\mathrm{E}$ were dissolved in small amount of ethyl ether and added to the $100 \mathrm{ml}$ of D-2 artificial medium. The rearing test was started with 10 third instar nymhs of both bugs which were kept in a $50 \mathrm{ml}$ beaker, and the result of survival is presented in Table 57. The experiments were repeated 5 times.

As illustrated in Table 57, an increase in survived individuals was obtained in the media which contained 0.5 to $2.0 \mathrm{mg}$ per $100 \mathrm{ml}$ media. Accordingly, in the medium devoid of vitamin, only a single bug generally survived on the 10 th day of rearing, while in the media added with vitamin, in most cases, 2 to 3 bugs still co-existed for a certain period of time. The excess amount of vitamin gave lower survival rate than the vitamin omitted media. The longevity was also prolonged in the bugs which were fed with media added with vitamin moderately. The vitamin content was seemingly more suitable in the concentration of 1.0 and $0.5 \mathrm{mg}$ per $100 \mathrm{ml}$ of media solution in $\boldsymbol{L}$. 
Table 57. Survival of Lyctocoris beneficus and Xylocoris galactinus reared gregariously with vitamin $\mathrm{E}$ added artificial media (started with 10 3rd instar nymphs, average of 5 tests).

\begin{tabular}{|c|c|c|c|c|c|c|c|}
\hline & $\begin{array}{c}\text { Content of } \\
\text { vitamin } \mathrm{E} \\
(\mathrm{mg} / 100 \mathrm{ml})\end{array}$ & $\begin{array}{c}\text { No. o } \\
2\end{array}$ & f surv & $\begin{array}{l}\text { ived b } \\
6 \quad 8\end{array}$ & $\begin{array}{l}\text { gs aft } \\
10\end{array}$ & r days & $\begin{array}{l}\text { Longevity } \\
\text { (in days)* }\end{array}$ \\
\hline L. beneficus & $\begin{array}{l}0.0 \\
0.5 \\
1.0 \\
2.0 \\
4.0\end{array}$ & $\begin{array}{l}4.2 \\
7.2 \\
6.6 \\
6.4 \\
5.4\end{array}$ & $\begin{array}{c}3.2 \\
6.4 \\
5.4 \\
5.8 \\
3.4\end{array}$ & $\begin{array}{c}2.4 \\
4.8 \\
3.8 \\
4.2 \\
2.6\end{array}$ & $\begin{array}{l}2.0 \\
3.6 \\
3.2 \\
2.0 \\
1.8\end{array}$ & $\begin{array}{l}1.2 \\
2.6 \\
2.8 \\
1.4 \\
1.2\end{array}$ & $\begin{array}{l}15.0 \\
23.4 \\
24.6 \\
20.6 \\
13.8\end{array}$ \\
\hline$X$. galact in us & $\begin{array}{l}0.0 \\
0.5 \\
1.0 \\
2.0 \\
4.0\end{array}$ & $\begin{array}{l}5.2 \\
7.4 \\
7.8 \\
7.4 \\
6.4\end{array}$ & $\begin{array}{c}3.6 \\
6.8 \\
5.6 \\
6.2 \\
4.4\end{array}$ & $\begin{array}{l}2.2 \\
6.4 \\
5.0 \\
4.8 \\
3.2\end{array}$ & $\begin{array}{c}1.4 \\
4.4 \\
3.6 \\
2.8 \\
1.8\end{array}$ & $\begin{array}{l}1.4 \\
3.2 \\
2.8 \\
2.2 \\
1.2\end{array}$ & $\begin{array}{l}12.8 \\
22.0 \\
20.8 \\
17.6 \\
14.2\end{array}$ \\
\hline
\end{tabular}

* average of maximum value from each test group.

beneficus and $\mathbf{X}$. galactinus respectively. Although the copulation was observed between the emerged adults but no egg was oviposited at all. From this fact it is apparent that vitamin $\mathrm{E}$ is not responsible for the egg production of L.beneficus. and X. galactinus. But a significant decrease in cannibalism was observed.

The result of the present experiments shows that some artificial media permit the restricted growth of bugs and the media of D-2 containing 0.5$1.0 \mathrm{mg} / 100 \mathrm{ml}$ are most prospective. But compared with the rearing result with animal diet, the rearing with artificial media is certainly inferior both in nutritional value and taste to the animal. diet.

\section{Ovarian development under certain nutritional conditions}

It is well known that insect reproduction is affected by many factors. Among them, nutrition is one of the most influential factors. And both qualitative and quantitative nutritional conditions give decided influences on the fecundity (Rasso and Fraenkel 1954, Harlow 1956, Wigglesworth 1960, Orr 1964, etc.). In Lyctocoris beneficus (Hiura) and Xylocoris galactinus (Fieber), higher fecundi.ties were obtained when these bugs were reared with the larvae of Tribolium castaneum (Herbst). While the bugs which were fed with the larvae of Chilosuppressalis (Walker) or Galleria mellonella (Linné) as food showed lower fecundities (cf. Chap. 9). Moreover, the bugs reared under the animal diet difficient condition scarcely laid eggs (cf. Chap. 8). From these facts, it is suggested that the quality of foods supplied influences the ovarian development of the bugs. In the individuals of both species which were reared with the larvae of $\mathbf{T}$. castaneum, the adult female frequently 
has a well-swollen abdomen. And sometimes, the abdomen becomes enlarged that the wings are covering only the four basal abdominal segments. However, in the newly emerged female or mature male the wings are covering the abdomen entirely. On the contrary, in the individuals which were fed with plant substances, the abdomen is always dwindled, and its length has few differentiations from that of male.

In the present work, the newly emerged adults which were fed from their 1st nymphal stadium with the larvae of $T$. castaneum were reared with the larvae of T. castaneum, C. suppressalis, G. mellonella or molded cracked corn. And the ovarian development was observed by dissecting the abdomen of 1,3 and 5 day old adult females. About 5 adults were dissected for each test and the number of eggs was counted and classified into three ranks according to their size (Tables 58 \& 59).

The development of ovarioles are also illustrated in Figures $10 \& 12$. In this experiment all the bugs were reared under $30^{\circ} \mathrm{C}$ condition. The preoviposition period of L.beneficus and X. galactinus under this condition was about 7 and 5 days respectively.

The reproductive organs of both species consist of one common oviduct, a pair of oviducts and ovaries. A oviduct is connected with 7 ovarioles. In the pre-mature adult, the terminal filament is extended to the mesothorax and the ends of the filaments are aggregated to one another. When the ovary is matured, the filaments bend posteriorly and their ends separate from each other. The filament is apparent in the pre-mature individuals, but shortened in the mature ones. The development of each ovariole in an

Table 58. Number and size of eggs in the ovariole of Lyctocoris beneficus reared with various foods.

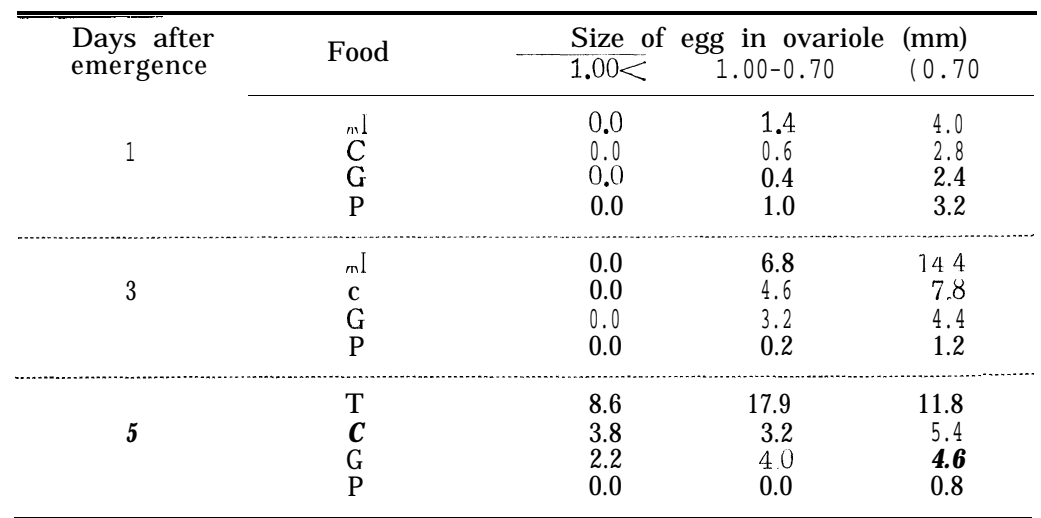

$\mathrm{T}$ : larvae of Tribolium castaneum.

C : larvae of Chilo suppressalis.

G : larvae of Galleria mellonella.

P : molded cracked corn. 
Table 59. Number and size of eggs in the ovariole of Xylocoris galactinus reared with various foods.

\begin{tabular}{|c|c|c|c|c|}
\hline $\begin{array}{l}\text { Days after } \\
\text { emergence }\end{array}$ & Food & $\begin{array}{l}\text { Size of } \\
0.6<\end{array}$ & $\begin{array}{c}\text { egg in ovariole } \\
0.60 \sim 0.40\end{array}$ & $\stackrel{(\mathrm{mm})}{<0.40}$ \\
\hline 1 & $\begin{array}{l}\mathrm{T} \\
\mathrm{C} \\
\mathrm{G} \\
\mathrm{P}\end{array}$ & $\begin{array}{l}0.0 \\
0.0 \\
0.0 \\
0.0\end{array}$ & $\begin{array}{r}12.4 \\
8.8 \\
7.2 \\
5.4\end{array}$ & $\begin{array}{r}8.8 \\
6.0 \\
12.4 \\
8.2\end{array}$ \\
\hline 3 & $\begin{array}{l}\mathrm{T} \\
\mathrm{C} \\
\mathrm{G} \\
\mathrm{P}\end{array}$ & $\begin{array}{r}13.2 \\
1.2 \\
0.0 \\
0.0\end{array}$ & $\begin{array}{r}12.0 \\
8.6 \\
7.8 \\
4.6\end{array}$ & $\begin{array}{l}9.6 \\
7.4 \\
6.4 \\
2.0\end{array}$ \\
\hline 5 & $\begin{array}{l}\mathrm{T} \\
\mathrm{c} \\
\mathrm{G} \\
\mathrm{P}\end{array}$ & $\begin{array}{r}13.8 \\
9.8 \\
2.4 \\
0.0\end{array}$ & $\begin{array}{r}18.2 \\
4.2 \\
4.8 \\
4.2\end{array}$ & $\begin{array}{r}12.6 \\
7.4 \\
6.0 \\
4.2\end{array}$ \\
\hline \multicolumn{5}{|c|}{$\begin{array}{l}\text { T: larvae of Tribolium castaneum. } \\
\text { C : larvae of Chilo suppressalis. } \\
\text { G : larvae of Galleria mellonella. } \\
\text { P : molded cracked corn. }\end{array}$} \\
\hline
\end{tabular}

individual is almost uniform, but the individual variation is certainly significant. The ovariole is generally transparent, but partly whitish opaque. The egg in the ovariole is white in colour, and the shape is globular at first and becomes oblong later. When the egg is fully matured, it becomes kidney-shaped and provides with a marked operculum which is easily detectable by a slight brown ring. The size of ovary is very variable with the age, nutritional condition etc., in the fully matured individuals it is about $3.2 \mathrm{~mm}$ in L. beneficus and $2.4 \mathrm{~mm}$ in X.galactinus.

The newly emerged adults of both species have small ovaries with slightly developed germarium and the abdominal coelum is filled with fat body. In Tribolium-fed $X$.galactinus, the significant ovarial development is recognized within one day rearing. On the third day, several mature eggs each with a distinct operculum appeared. While through the author's experiment, no example was obtained as to the production of an egg after 3 day pre-oviposition period. On the fifth day slight numerical increment on mature eggs was observed, however, a marked change was characterized rather by the development of pre-mature eggs. In the individuals reared with the larvae of C. suppressalis and G. mellonella, the appearance of mature eggs were surely retarded than $\mathbf{T}$. castaneum reared individuals, and mature eggs were scarcely recognized in 3 day old adults. The number of pre-mature eggs was also less than that of Tribolium reared bugs. In the individuals which were fed with only plant-substances after emergence, some retardation on the ovarian development was already observable within 24 hours. While the dfferentiation became more significant in the later stage. The especially noticeable fact 


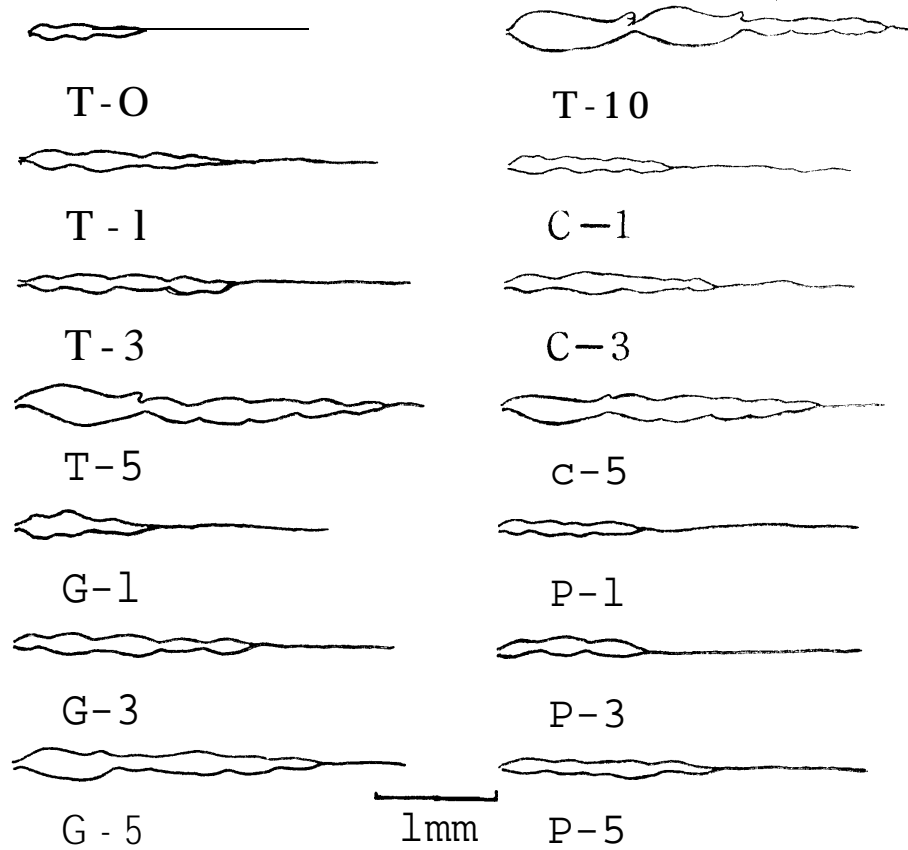

lig. 10. Ovarial development of Lyctocoris beneficus reared with various foods. $\mathrm{T}$ : reard with larvae of Tribolium castaneum. C: reared with larvae of Chilo suppressalis. G: reared with larvae of Galleria mellonella. P: reared with molded cracked corn. Figure after hyphen indicates the day after emergence.

was that till the third day slight ovarian development was still seen, but on the fifth day the ovary rather shrinkled. And in this group, of course, no maturation of eggs was observed at all. This phenomenon postulates the indispensability of the animal diet on the ovarian development of these Anthocorid bugs. The shrinkage of the ovary in the individuals fed with plant-substances was also observed in L.beneficus.

In L.beneficus, the ovarian development was apparently slow than that of $X$.galactinus, and in the Tribolium-fed bugs the mature egg appeared on the fifth day. The effect of other foods on the ovarian development was very similar to that of $\mathrm{X}$. galactinus.

In the fully matured female the number of mature eggs in the ovary was unexpectedly high, and the maximum figure was 42 in L.beneficus and 35 in $\mathrm{X}$. galactinus. In such individuals, of course, the oviposition takes place, but they do not deposit all of the mature eggs at once. The plumpness of abdomen continues almost through her life, and the female frequently dies with many mature eggs left in the ovary. 

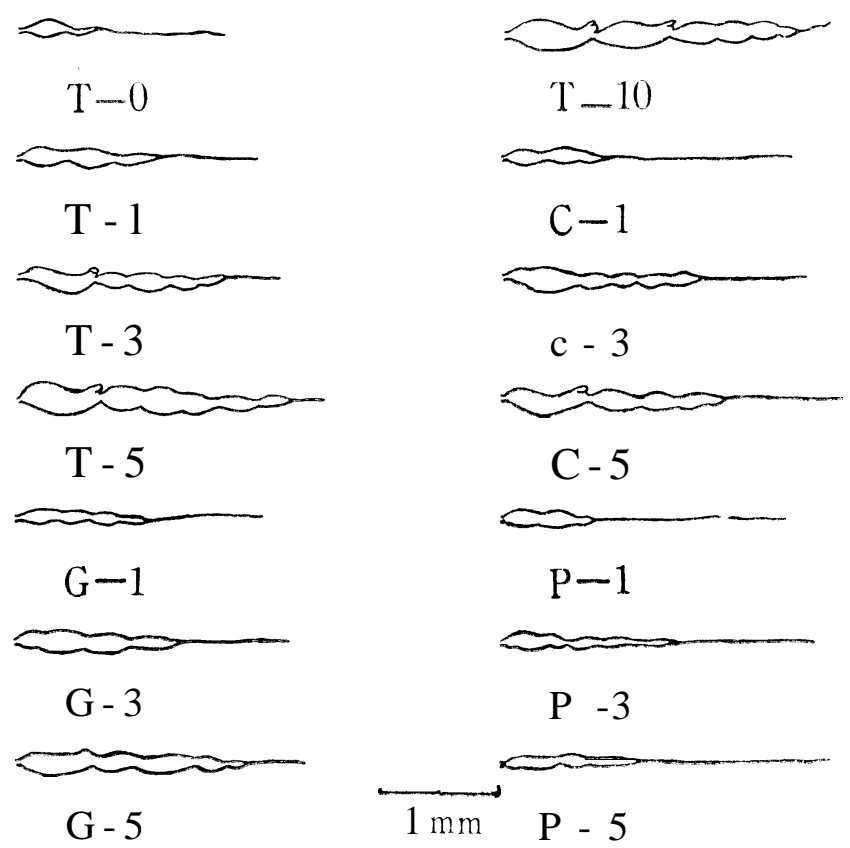

Fig. 11. Ovarial development of Xylocoris galactinus reared with various foods.

\section{Effects of population density on the survival, growth and fecundity}

The effects of population density on the survival, growth and fecundity of many species of animals greatly depend on species and developmental stage (Allee 1934). When the population density increases, food, available space, sanitation, cannibalism and certain other factors increase their importance. Among insects, population growth has been shown to be influenced by the contracting influences of mating and cannibalism or predatism (especially of the eggs). Further the cannibalism or predatism is more prevalent in the denser population (Park 1932, Chapman 1928, Chapman and Whang 1934, Maclagen 1932, Boyce 1946, Park et al. 1965). Generally, crowding is recognized to be unfavourable to the growth of some cockroaches, Tenebrio beetle, etc., and the bad effects caused by crowding on animals are attributed predominantly to physical rather than chemical factors (Allee 1934, Chauvin 1946), and to chemical influences especially of specific pheromones by some workers (Butler 1954, Norris 1954, Lüscher 1956, Loher 1961). Prior to start their practical mass production, it is an important problem to decide the most suitable density on the growth process and fecundity of Lyctocoris beneficus (Hiura) and Xylocoris galactinus (Fieber). The author reared various 
developmental stages of both bugs under various population conditions and observed the effects on their development and offspring production.

In this experiment the laboratory reared individuals were used, and they were bred in a plastic container which was $12 \mathrm{~cm}$ in length, width and height each, or some different sized containers and always supplied with sufficient Tribolium larvae as food. Although the density of the prey also may influences the growth of predator, this factor was not taken into consideration in the present work. The population counting was carried out every three days, and the detailed experimental procedures are described in each experiment.

\section{Effect of populatlon density on the survival of adults.}

Various numbers of newly emerged L.beneficus and X. galactinus adults were kept in a plastic container which was provided with molded or dry cracked corn about $1 \mathrm{~cm}$ thick and sufficient numbers of Tribolium larvae. The survival of adult bugs was counted every 3 days (Table 60).

Table 60. Survival of Lyctocoris beneficus and Xylocoris galactinus adults under various population densities.

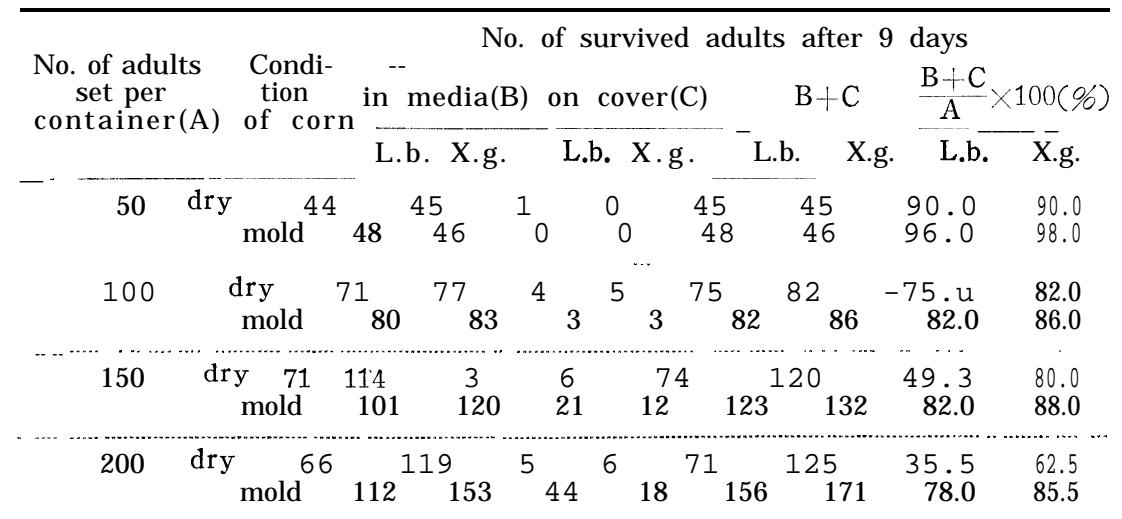

During this test, there was observed not a few individuals of L.beneficus on the cover of the container especially in denser groups. The result of marking test with diluted white poster colour on their pronotum indicated that the majority of individuals found on the cover were inactive for a long time. Therefore, these adults were supposed to be expelled individuals from the media by the density pressure. Consequently, they are counted in the other column in the Table. It is worth to notice that when the medium was over moistened, more individuals climbed up to the cover, while in such a medium the survival was, on the contrary, higher in both species. This is considered as the results of broadening of their territories in the 
moist condition. The higher rate of survival was obtained in the moist corn medium, while in the excessively moist medium the mortality was apparently higher than that of the dry medium. The cover staying individuals were scarcely observed in X.galactinus which has much smaller body size and was generally living aggressively under more moist condition in the field. Though the survival data shown in Table 60 are the result of 9th day, the significant decrease of population occurred during the first 3 days and further decrease of population was almost neglizible in the later six days. If the bugs staying on the cover are considered as individuals which are not participate in the reproduction of the species, the maximum supporting capacity of $\boldsymbol{L}$. beneficus and X. galactinus in the dry corn medium was about 70 and 120 respectively, and that on the molded corn medium was 100 and 150 respectively. This fact is seemingly illustrating a conflict that the moist medium has larger capacity than the dried one. But this is rather explained by the less occurrence of cannibalism or predatism in the moderately molded medium. The bug supporting capacity of medium has such a limit that even the addition of more medium material does not increase the supporting capacity of the given container.

\section{Effects of population density on the egg production and hatching rate.}

The fecundity, or oviposition rate of many animals shows a sensitivity to the population density (Norris 1950, 1952, 1959, Albrecht et al. 1958, Zaher 1959, Watt 1960, Green 1954). Copulation occurs most frequently in the moderately dense population which permits chance to mate and produces more fertile eggs (Pearl et al. 1922, 1927, Pearl 1932). To examine the density effect on the fecundity of the bugs, 1, 2, 5, 10 and 20 pairs of adults of 8 to 10 day old $L$. beneficus and 6-8 day old $X$. galactinus were reared separately in a $6 \times 9 \mathrm{~cm}$ (height $\mathrm{x}$ diameter) petri-dish which was provided with $1 \mathrm{~cm}$ depth of molded corn, namely about $64 \mathrm{~cm}^{3}$ in volume that was approximately half the volume of corn medium of the preceding test, namely $144 \mathrm{~cm}$ ". Therefore, so far as the corn medium volume was concerned, 20 pairs per dish corresponded 80 adults in the plastic container. In this test, the adults deposited all the eggs in the corn medium, because no moist filter paper was provided. As it was difficult to count the number of eggs laid in corn, the corn was renewed every three days, and the number of newly hatched nymphs was counted as an index of fecundity, and the average of 5 replications are shown in Table 61 . In another series of test, the fertility of eggs was investigated by counting of the rate of hatching of eggs which were laid on the moist filter paper. Of course in such a test a part of eggs were laid in the corn medium. Therefore, only the ratio of fertilized and unfertilized eggs was obtained.

Though the percentage of fertile eggs and the number of eggs pierced by the bug in the corn medium are very difficult to count, the most ideal 
case of the density was 10 pairs in L.beneficus and 20 pairs in X.galactinus to get the maximum offspring production, and bad-crowding effect was observed in the denser group of $\boldsymbol{L}$. beneficus. The egg-fertility was not affected by the density. However, no detailed data were available. The predation of eggs by the adults was significantly more active in the denser groups, especially when the filter paper habouring eggs were exposed to the adults for about a day.

Table 61. Number of hatched nymphs and fertility of eggs of Lyctocoris beneficus and Xylocoris galactinus under various population densities (average of 5 replicates).

\begin{tabular}{ccccccc}
\hline \multirow{2}{*}{$\begin{array}{c}\text { No. of adults } \\
\text { per dish (pairs) }\end{array}$} & \multicolumn{2}{c}{ Total nymphs } \\
hatched per day & \multicolumn{2}{c}{$\begin{array}{c}\text { No. of nymphs } \\
\text { per female }\end{array}$} & \multicolumn{2}{c}{$\begin{array}{c}\text { Percent } \\
\text { fertility(\%) }\end{array}$} \\
1 & L.b. & X.g. & L.b. & X.g. & L.b. & X.g. \\
2 & 2.6 & 3.2 & 2.6 & 3.2 & 88.1 & 90.3 \\
5 & & & & & & \\
10 & 17.06 .4 & 19.47 .0 & 3.43 .1 & 39.93 & 94.392 .2 & 88.189 .6 \\
20 & 34.8 & $38 . G$ & 3.5 & 3.9 & 91.7 & 93.1 \\
& 55.8 & 86.2 & 2.8 & 4.3 & 87.6 & 95.6
\end{tabular}

\section{Effect of population density on the growth and survival of nymph.}

Although crowding condition is unfavourable to the nymphal growth of many insects, the retardation of growth by isolated rearing is also observed (Michal 1931, Landowski 1937, Petit 1940, Willis et al. 1958, Feir 1963, Kunnel 1966). The density effect on the growth and survival of nymphs was investigated with a similarly provided petri-dish. Six petri-dishes each of which was provided with $1,10,20,40,60$ and 80 newly hatched nymphs respectively were observed to detect the effect of crowdness on the body weight and mortality (Table 62). To keep the young nymphs

Table 62. Effect of density on the nymphal growth of Lyctocoris beneficus and Xylocoris galactinus (average of 2-5 replicates),

\begin{tabular}{ccccccc}
\hline \multirow{2}{*}{$\begin{array}{c}\text { Nymphs per } \\
\text { dish }\end{array}$} & \multicolumn{2}{c}{ Avg. days to } & \multicolumn{2}{c}{$\begin{array}{c}\text { Avg. weight of } \\
\text { adult }\end{array}$} & \multicolumn{2}{c}{ Percent } \\
& L.b. & X.g. & L.b. & X.g. & L.b. & X.g. \\
1 & 25.2 & 15.8 & 2.3 & 1.4 & 77.4 & 87.8 \\
10 & 24.4 & 15.5 & 2.3 & 1.4 & 78.6 & 91.4 \\
20 & 24.6 & 15.4 & 2.4 & 1.5 & 72.4 & 87.4 \\
40 & 23.9 & 15.1 & 2.4 & 1.5 & 74.6 & 78.0 \\
60 & 23.3 & 14.8 & 2.3 & 1.4 & 51.2 & 76.2 \\
80 & 23.4 & 14.6 & 2.3 & 1.4 & 48.7 & 75.6
\end{tabular}


from the mechanical damage to a minimum level, the dishes have never been disturbed until the emergence of new adults since the release of newly hatched nymphs. Of course, consideration was made in keeping the humidity and supply of food if necessary.

Primarily, on the basis of percent of survival, it is concluded that any number of nymphs of $\boldsymbol{L}$. beneficus from 1 to 40 reared aggressively in a dish, and that of $X$. galactinus from 1 to 60 showed constantly high emergence ratio. When the density exceeded this range, the increase in nymphal mortality was observed in both species, and the offspring were smaller, But this was not due to the shortage of food, as the sufficient food was always supplied in the dish. The results would indicate that moderate gregarious rearing condition or moderate population density is preferable for the normal nymphal development of both species.

\section{Competition between adults and nymphs under the conditions of different densities.}

During the process of practical mass production of the species, an adultnymph complex may occur in the rearing medium. Therefore, the effect of adult population on the nymphal development seems to be an important factor to determine the efficiency of bug production.

In this test, the groups of $1,5,10$ and 20 adults were placed separately in a $6 \times 9 \mathrm{~cm}$ petri-dish which was previously provided with 25 newly hatched nymphs and $1 \mathrm{~cm}$ depth of molded corn. Then the survival and nymphal growth were observed. As the distinction between the old and newly emerged adult was difficult, the observation was stopped when about half of the tested nymphs became the fifthinstar (Table 63).

Table 63. The effect of adult numbers on the nymphal growth of Lyctocoris beneficus and Xylocoris galactinus.

\begin{tabular}{|c|c|c|c|c|c|}
\hline \multicolumn{2}{|c|}{$\begin{array}{l}\text { Initial no. of } \\
\text { bugs per dish }\end{array}$} & \multicolumn{2}{|c|}{$\begin{array}{l}\text { Avg days to } 5 \text { th } \\
\text { instar }\end{array}$} & \multicolumn{2}{|c|}{$\begin{array}{c}\text { Nymphal survival } \\
(\%)\end{array}$} \\
\hline Adult & Nymph & Lb. & X.g. & Lb. & $x . g$. \\
\hline 0 & 25 & 17.3 & 10.4 & 78 & 82 \\
\hline 1 & 25 & 17.3 & 10.5 & 78 & 80 \\
\hline 5 & 25 & 17.2 & 10.8 & 82 & 78 \\
\hline 10 & 25 & 17.5 & 10.7 & 72 & 84 \\
\hline 20 & 25 & 16.9 & 11.2 & 46 & 76 \\
\hline
\end{tabular}

The data in Table 63 indicate that the bad effect of mixed-rearing of both adults and nymphs on the nymphal growth occurs when 20 adult $L$. beneficus are used, but this is not the case in $X$. galactinus. The shortening of the duration of nymphal stages is observed in denser groups of both species. 
In conclusion, to rear the bugs in a $6 \times 9 \mathrm{~cm}$ petri-dish efficiently, the mother strain is advisable to start with less than 20 or 40 adults of $L$. beneficus and $X$.galactinus respectively. The results of rearing experiments in the petri-dishes may be applicable to the rearing in the large plastic container in which it can accomodate about twice the number of individuals.

\section{Overwintering and cold-hardiness}

The Anthocorid bugs are generally known to overwinter in the adult stage, especially as fertilized females. They hibernate beneath tree barks, leaves, or litters on the ground. Though there are no detailed observations on the hibernation of Lyctocoris beneficus (Hiura) and Xylocoris galactinus (Fieber), the latter species is generally known from the warmer stock yard where usually few seasonal variations occurred (Hall 1951, Sinha 1961). Moreover, Hall pointed out that the bugs develop continuously throughout the year. Besides, some adult specimens of both species which were collected during the winter months were examined by Hiura $(1957,1966)$ in his taxonomic work. From this fact, it is evident that in the cold season, these species overwinter at least in the adult stage. Fortunately, the author could collect several adults of L. beneficus at the stock yard of a farm in Kyushu in January. During early spring, he also collected many specimens of the adult $X$. galactinus from the straw piles at Saga in Kyushu, and it may be mentioned that in both collections the author could not obtain any nymphs.

In the first experiment on the studies of the overwintering, the work on the cold-hardiness of these bugs was carried out. Various stages of bugs previously kept in $25^{\circ} \mathrm{C}$ condition were used in this experiment. During the time-temperature exposure, the bugs were kept in organdy clothed $100 \mathrm{ml}$ beaker which was provided with a sheet of moist filter paper and enough prey. Then, they were exposed to the temperatures of $-3^{\circ},+5^{\circ}$ and $+7^{\circ} \mathrm{C}$ for a certain period. The beakers were taken out from the cold chamber and placed under the room temperature condition. The mortality of bugs was estimated 24 hours after the exposure of the room temperature condition and the bugs which did not respond to the warmer temperature were counted as killed. All time-temperature exposure experiments were conductd with the use of bugs and repeated 5 times.

In the test under $-3^{\circ} \mathrm{C}$ condition, all the stages of both species stopped their activities within 3 minutes, and exposure with such coldness for more than 30 minutes was extremely fatal to them, and 1 hour's treatment obtained $100 \%$ mortality in both species. Under $5^{\circ} \mathrm{C}$ condition, they became inactive within 10 minutes. And within 1 hour almost all the individuals drew their legs and turned over, though few of them wriggled their legs feebly. The period needed to inactivate L. beneficus was seemed a little longer than in $X$. galactinus. In a short period treatment, these inacti- 
vated individuals were readily recoverd when they were removed to the room temperature condition. While in the longer duration of temperature treatment, the time necessary to recover was prolonged proportionally. When the duration of treatment exceeded a certain threshold, the bugs did not recover at all. The mortality after certain periods of exposure is indicated in Table 64.

Table 64. The mortality of Lyctocoris beneficus and Xylocoris galactinus under $5^{\circ} \mathrm{C}$ condition ( $\%$ ).

\begin{tabular}{|c|c|c|c|c|c|c|c|}
\hline \multirow{2}{*}{\multicolumn{2}{|c|}{$\begin{array}{l}\text { Anthocorid bug } \\
\text { and stage }\end{array}$}} & \multirow{2}{*}{\multicolumn{6}{|c|}{$\begin{array}{l}\text { Exposure period (in days) and } \\
\text { mortality (in numbers) }\end{array}$}} \\
\hline & & & & & & & 6 \\
\hline \multirow{5}{*}{ L. beneficus } & 1st instar & 76 & 90 & 100 & - & & - \\
\hline & 3rd instar & 3.2 & 1.8 & 45 & 92 & 100 & - \\
\hline & 5 th instar & 38 & 24 & 24 & 32 & 86 & 100 \\
\hline & adult $\overparen{\circlearrowleft}$ & 14 & 14 & 30 & 38 & 84 & 100 \\
\hline & ㅇ. & 6 & 10 & 20 & 18 & 78 & 3.00 \\
\hline \multirow{5}{*}{$X$. galactinus } & 1st instar & 86 & 100 & & - & & \\
\hline & 3rd instar & 14 & 26 & 88 & 100 & - & - \\
\hline & 5 th instar & 10 & 24 & 46 & 94 & 100 & - \\
\hline & adult $\overparen{\partial}$ & 14 & 18 & 28 & 82 & 100 & - \\
\hline & 우 & 10 & 10 & 22 & 64 & 100 & - \\
\hline
\end{tabular}

It is evident that the first instar nymphs of both species are extremely sensitive against the coldness, and the third instar nymphs are more tolerable than the first instar ones. While the cold-hardiness of these nymphs are certainly inferior to that of the older nymphs and adults. In the mature nymphs and adults, the death caused by coldness began to start from the fifth day and the fourth day in $L$. beneficus and X. galactinus respectively. And this fact suggests the higher tolerance of $L$. beneficus than X. galactinus against the low temperature.

The temperature condition of $7^{\circ} \mathrm{C}$ was much more favourable for the survival of bugs, especially in mature nymphs and adults. Compared with the results of rearing at room temperature, no significant increase in the mortality of these individuals was observed under this condition. However, all the tested nymphs of the firstinstar of $\mathrm{X}$. galactinus died within 5 days and none of them developed to the second instar. In L.beneficus, a part of the first instar nymphs moulted once after 7-10 days, but all of them died during the second stadium. In the third instar nymphs of both species, some individuals were able to become adults and the percent emergence was higher in $\boldsymbol{L}$. beneficus than in $X$. galactinus. Though the copulation was observed in these adults, the oviposition did not occur at all. The longevity of adults differed significantly between the two species, viz. in the adult 
female of $X$.galactinus, it was less than 40 days but more than 90 days in $L$. beneficus. These figures are of course the result obtained under the temperature condition of $7^{\circ} \mathrm{C}$. But if reared under a mild temperature condition, no remarkable difference in the longevity was seen. And the results of this test strongly suggests the fact that L.beneficus is more cold-adapted than $X$. galactinus. On the other hand, it is also worthy of mention that in a usual environment, there exists only a slight difference in longevity between the female and male individuals, while in such an oviposition restrained condition the longevity of adult female surpassed that of male significantly. And this fact further suggests that the female is consequently more adapted to the survival in the colder season than male.

Table 65. Growth of the 3rd instar nymphs of Lyctocoris beneficus and Xylocoris galactinus under $7^{\circ} \mathrm{C}$ condition.

\begin{tabular}{|c|c|c|c|c|c|}
\hline & \multicolumn{4}{|c|}{ Duration of stage in days } & \multirow{2}{*}{$\begin{array}{c}\text { Percent } \\
\text { emergence }(\%)\end{array}$} \\
\hline & 4 th & 5 th & $\sigma^{\top}((\mathbf{a} d u l t)$ & 우 (adult) & \\
\hline L. beneficus & $\begin{array}{l}18.6 \\
(5.2)\end{array}$ & $\begin{array}{l}23.4 \\
\mathbf{( 5 . 4 )}\end{array}$ & $\begin{array}{c}38.4 \\
(32.2)\end{array}$ & $\begin{array}{c}92.1 \\
(32.0)\end{array}$ & $\begin{array}{c}\mathbf{5 8} \\
(90)\end{array}$ \\
\hline X. galactinus & $\begin{array}{l}12.7 \\
(2.0)\end{array}$ & $\begin{array}{l}19.5 \\
(4.8 \mathrm{j}\end{array}$ & $\begin{array}{c}24.3 \\
(30.3)\end{array}$ & $\begin{array}{c}37.8 \\
(26.8)\end{array}$ & $\begin{array}{c}32 \\
(95)\end{array}$ \\
\hline
\end{tabular}

The figure in parenthesis shows the data obtained at room temperature.

In autumn, the field collected adults of both species have low oviposition capacity than the spring or summer collected individuals. Even the autumn collected adults were kept under $30^{\circ} \mathrm{C}$ and $25^{\circ} \mathrm{C}$ conditions in the laboratory, they could not resume their fecundity. Although the individuals which were reared under $7^{\circ} \mathrm{C}$ condition in the laboratory readily resumed their fecundity when they were removed to the warmer environment. Therefore, low temperature in the autumn season is not a decisive factor to reduce the fecundity of autumn individuals. The short day-time seems not to influence this phenomenon, because the laboratory strain which are kept in dark condition always show satisfactory results both in growth and reproduction. One of the presumable reason in the low fecundity may be ascribed to the shortage of food, as in this season, compared with summer or spring, the prey fauna in the straw pile is actually poor. Moreover, the results of laboratory experiments indicate that the effect of mal-nutritional condition lasts for a certain long period and is not easily compensated with the additional food supply in the later period. The process of low fecundity in this season seems to be partly explained by the natural regulation in the species so as to keep the population in the cold season as high as possible, namely because the young nymphs cannot withstand the coldness, while the females can tolerate against this if they stop oviposition.

Although the bug cannot be collected on the surface of straw pile in the 
winter, the coldness does not seem to play an essential part in reducing the absolute population of bugs. Because, according to the data from the Saga Paper Board Co., the temperature of giant straw pile in winter is unexpectedly high, namely that of the innermost part is recorded as $70-80^{\circ} \mathrm{C}$ in the fermenting straw pile and sometimes the temperature is so high as to cause the carbonization of straw. Even in a well-dried straw pile, it was more than $20^{\circ} \mathrm{C}$. Although this is lower than the optimum temperature for the growth of the bugs, the data in the laboratory rearing experiment pointed out that they can easily keep such a condition for a longer period. Of course, the temperature of the outer part of the straw pile nearly coincides with the natural temperature that is $4^{\circ} \mathrm{C}$ in mid-winter on an average in northern part of Kyushu, and is often going down to below $0^{\circ} \mathrm{C}$ for a short period. In the fermenting pile, there exists a gradient of temperature gradually decreasing from $80^{\circ} \mathrm{C}$ to $4^{\circ} \mathrm{C}$ from the central part to the outer surface of the pile, and of course it is producing a mild temperature area between the surface and the central part. Therefore, taking in consideration the temperature only, the disappearance of bugs from the surface of straw pile during the winter season and the emigration of bugs into the central part of thatch so as to escape the death of bugs caused by the coldness are the reasonable phenomena. The emigrated individuals will stay in a suitable temperature area, and in the dried thatch the bugs emigrate far deeply. Actually the author collected a number of adult specimens from a considerably inner part of the straw pile in early spring, and these seemed undoubtedly to be the over-wintered individuals in this area. Though Hall (1951) indicates that X.galactinus develops through the year in stock yard condition, the author could not collect any nymphs of this species in the field during the winter season. But the bugs of laboratory reared stock continuously grew and produced offspring in the vermiculite or molded corn culture where the condition was more or less similar to that of the grain bins.

\section{Relative toxicity of pesticides}

The objective of blending chemical and biological control in an integrated control or modified program for pest suppression has been widely discussed recently (Stern et al. 1959, van den Bosch and Stern 1962, Bartlett 1964, Beirne 1967, etc.). On the other hand, the previous worker-s demonstrated both in laboratory and field tests that some organic pesticides have differential toxicity to numerous entomophagous arthropods (Bartlett 1963, Herne and Putman 1966, Lingren and Ridgway 1967 etc.). Therefore, prior to the establishment of the harmonization of natural enemies and pesticidal applications, the effects of pesticides on the survival and behaviour of natural enemies should be thoroughly studied. 
The predation of the rice stem borer (Chilo suppressalis (Walker)) by Lyctocoris beneficus (Hiura) and Xylocoris galactinus (Fieber) was already discussed in the former part of this work. When these Anthocorid bugs are practically liberated in the paddy fields or the other borer infested areas, the influence of pesticidal applications on the bugs would become an unneglizible factor to determine the practical value of these bugs as rice stem borer controlling agents.

The review of the literature reveals that Anthocorid bugs are also destroyed by many pesticides as the other entomophagous insects. The first report on the toxicity of pesticides against Anthocorid bugs was introduced by Hill (1945) who reported the reduction of population of Orius spp. by the spray of DDT. Since then, voluminous works have been done on the reduction of Anthocorid bug population in the natural condition after the application of pesticides. The relevant experiments of the laboratory works on the relative toxicity of pesticides against the Anthocorid bugs were done by Burke (1959), Gratwick (1965) and Lingren and Ridgway (1967). Namely, Gratwick evaluated the toxicity of 11 insecticides which were usually used for orchard insect pests control against Anthocoris nemorum (Linné) with direct spray and residual toxicity methods. The toxicity of some insecticides against Orius insidiosus (Say) was studied by two other authors.

Concerning the insecticidal toxicity against L.beneficus, the first work was done in Saga Agricultural Experimental Station in Japan, and the extremely high toxicity of BHC, DDT, dieldrin, aldrin, malathion and parathion dusts was reported (Anonym 1954). The toxicity of BHC was also proved by Oho (1955a, b). But the similar kind of study on X.galactinus has not yet been carried out.

In the present work, 8 insecticides and 2 acaricides were tested. Among them, first 5 chemicals are commonly used in the paddy field and latter 5 in orchard in this country.

The names of insecticides and acaricides used are listed as follow :* Dipterex $50 \%$ E. C. 2, 2, 2-trichloro-1-hydroxyethyldimethyl phosphonate.

Methyl parathion $40 \%$ E. C. 0, 0-dimethyl 0-p-nitrophenyl phosphorothioate.

Sumithion $50 \%$ E. C. 0, 0-dimethyl-0-3-methyl-4-nitro phenyl phosphorothioate.

Sevin $15 \%$ E. C. 1 -naphthyl N-methylcarbamn te.

Elsun $50 \%$ E. C. ethyl 0, 0-dimethyl dithiophosphoryl-1-phenylacetate.

Formothion $45 \%$ E. C. 0, 0-dimethyl-S-(N-methyl-N-formoylcarbamoylmethyl) phosphorodithioate.

Dimethoate $43 \%$ E. C. 0, 0-dimethyl S-(N-methylcarbamoylmethyl)-dithiophosphate. Diazinone $34 \%$ W. P. 0, 0-diethyl O-(2-isoproyl-4-methyl-6-pyrimidinyl) phosphorothioate.

* All the pestici.des used in this test were kindly furnished by Mikasa Chemical and Industrial Co., Ltd. 
Akar (=chlorobenzilate) $21 \%$ E. C. 4,4'-dichlorobenzoic acid ethyl ester.

Tedion $8 \%$ E. C. 2, 4, 5, 4-tetrachlorodiphenylsulphon.

For the testing method, residual-film method was applied throughout this work. Thus, $1.0 \mathrm{ml}$ of pesticidal preparation was uniformly soaked into a set of filter paper which was composed of one rectangular sheet $(9 \times 6.3$ $\mathrm{cm}$ ) and two discs (2 $\mathrm{cm}$ in diameter). After the immersion to the solution, the filter paper was dried completely under the room temperature condition. The desiccated filter paper was fixed to the interior surface of a glass vial which was $9 \mathrm{~cm}$ and $2 \mathrm{~cm}$ in length and diameter respectively. Then 10 bugs were released in each vial. After 1 hour's contact with the treated filter paper, the bugs were removed to a clean glass vial of the same size supplied with larvae of Tribolium castaneum (Herbst) and a piece of moist filter paper. The survival of tested bugs was estimated 12, 24 and 48 hours after the treatment, then moribound individuals were counted as killed. As a check of test, water soaked filter paper was used instead of chemical soaked paper. The test was replicated 5 times in each test, and all the works were conducted under $25^{\circ} \mathrm{C}$ condition.

For the preliminary test, laboratory reared adults were used and 5-6 day old $L$. beneficus and 3-4 day old X. galactinus were selected for experiments. These adults have been fed with sufficient diet of the larvae of T. castaneum from their 1st nymphal stadium. The effect of pesticides on the mortality of $L$. beneficus and X.galactinus are given in Tables 66 and 67 respectively.

Among the pesticides tested, the concentration of sevin and two acaricides are apparently lower than the other chemicals. This is merely due to the low concentration of the effective ingredient in the original formulation. Accordingly the other pesticides contain about $40 \%$ of ingredient, and those of sevin, akar and tedion are only 15, 21 and 8 percent respectively. Therefore, it is surely hard to prepare entirely homogenized emulsion in higher concentrated level with those formulation. Neverthless, in such low concentrations, those evidently surpass the conventional concentration in the field application, namely those are about 0.03 and $0.01 \%$ in sevin and two acaricides respectively. On the other pesticides, the conventional concentrations are about $0.05 \%$.

Tables 66 and 67 show that $\boldsymbol{L}$. beneficus is slightly more sensitive than $X$. galactinus against all the tested pesticides. For both species of bugs, only parathion shows very high toxicity in the conventional dosage and on this level no other pesticides show significant toxicity. Although sumithion is the next toxic pesticide, in both species more than $80 \%$ mortality is obtained in $0.2 \%$ solution that contains about 4 times as many dosage as that of the conventional preparation. Tables 66 and 67 also indicate that the higher toxicity is demonstrated in organic phosphate compounds than in carbamate compounds. The high toxicity of the former compounds than 
Table 66. Effect of pesticides upon the mortality of 5-6 day old adult of Lyctocoris beneficus reared in the laboratory.

\begin{tabular}{|c|c|c|c|c|}
\hline \multirow{2}{*}{ Pesticides } & \multirow{2}{*}{$\begin{array}{l}\text { Concentration } \\
\text { of effective } \\
\text { ingredient }(\%)\end{array}$} & \multicolumn{3}{|c|}{ Percent mortality } \\
\hline & & $12 \mathrm{hr}$ & $24 \mathrm{hr}$ & $48 \mathrm{hr}$ \\
\hline Dipterex & $\begin{array}{l}0.20 \\
\mathbf{0 . 5 0}\end{array}$ & $\begin{array}{r}4 \\
22\end{array}$ & $\begin{array}{r}6 \\
26\end{array}$ & $\begin{array}{r}8 \\
26\end{array}$ \\
\hline Dimethoate & $\begin{array}{l}0.10 \\
0.20 \\
0.50\end{array}$ & $\begin{array}{l}12 \\
38 \\
66\end{array}$ & $\begin{array}{l}14 \\
40 \\
74\end{array}$ & $\begin{array}{l}14 \\
44 \\
74\end{array}$ \\
\hline Diazinone & $\begin{array}{l}0.05 \\
0.10 \\
\mathbf{0 . 2 0}\end{array}$ & $\begin{array}{l}10 \\
38 \\
78\end{array}$ & $\begin{array}{l}10 \\
38 \\
80\end{array}$ & $\begin{array}{l}12 \\
42 \\
80\end{array}$ \\
\hline Sumithion & $\begin{array}{l}0.05 \\
0.10 \\
\mathbf{0 . 2 0}\end{array}$ & $\begin{array}{r}0 \\
10 \\
84\end{array}$ & $\begin{array}{r}4 \\
10 \\
86\end{array}$ & $\begin{array}{r}4 \\
12 \\
86\end{array}$ \\
\hline Methyl parathion & $\begin{array}{l}0.012 \\
0.025\end{array}$ & $\begin{array}{r}94 \\
100\end{array}$ & $\begin{array}{r}96 \\
100\end{array}$ & $\begin{array}{r}96 \\
100\end{array}$ \\
\hline Formothion & $\begin{array}{l}0.20 \\
0.50\end{array}$ & $\begin{array}{r}0 \\
14\end{array}$ & $\begin{array}{r}8 \\
18\end{array}$ & $\begin{array}{r}8 \\
18\end{array}$ \\
\hline Elsun & $\begin{array}{l}0.20 \\
0.50\end{array}$ & $\begin{array}{r}8 \\
16\end{array}$ & $\begin{array}{l}10 \\
16\end{array}$ & $\begin{array}{l}3.0 \\
16\end{array}$ \\
\hline Sevin & $\begin{array}{l}0.05 \\
0.15\end{array}$ & $\begin{array}{l}18 \\
22\end{array}$ & $\begin{array}{l}20 \\
22\end{array}$ & $\begin{array}{l}20 \\
24\end{array}$ \\
\hline Akar & $\begin{array}{l}0.20 \\
\mathbf{0 . 4 0}\end{array}$ & $\begin{array}{l}2 \\
4\end{array}$ & $\begin{array}{l}4 \\
4\end{array}$ & $\begin{array}{l}4 \\
4\end{array}$ \\
\hline Tedion & $\begin{array}{l}0.10 \\
0.15\end{array}$ & $\begin{array}{l}0 \\
0\end{array}$ & $\begin{array}{l}2 \\
0\end{array}$ & $\begin{array}{l}2 \\
0\end{array}$ \\
\hline $\mathrm{CK}$ & & 0 & 2 & 2 \\
\hline
\end{tabular}

the other series of pesticides against the entomophagous insects are also indicated by some workers (Bartlett 1963, Yun and Ruppel 1964, etc.). Both akar and tedion are very slightly harmful against the bugs even in 10 times as many dosage as the conventional concentration.

The relative toxicity of these pesticides against the field collected adult bugs was also tested with the same method. Hereon, the author used $L$. beneficus of the autumn generation and X. galactinus of the spring generation. All the individuals were used to experimental purposes within 12 hours after collection (Tables 68 \& 69).

As seen in Tables, field collected individuals were significantly sensitive than laboratory reared ones in both species. Among the highly toxic chemicals, however, only parathion is ranked to most dangerous against the laboratory strain. While diazinone and sumithion belong to the group of dangerous compounds against field collected bugs. Besides, dipterex, dimethoate and formothion showed moderate toxicity. Although other pesticides were less toxic, the mortality of field collected material against these chemicals were apparently higher than that of laboratory reared 
Table 67. Effect of pesticides upon the mortality of 5-6 day old adult of Xylocoris galactinus reared in the laboratory.

\begin{tabular}{|c|c|c|c|c|}
\hline \multirow{2}{*}{ Pesticides } & \multirow{2}{*}{$\begin{array}{l}\text { Concentration } \\
\text { of effective } \\
\text { ingredient }(\%)\end{array}$} & \multicolumn{3}{|c|}{ Percent mortality } \\
\hline & & $12 \mathrm{hr}$ & $24 \mathrm{hr}$ & $48 \mathrm{hr}$ \\
\hline Dipterex & $\begin{array}{l}0.02 \\
0.50\end{array}$ & $\begin{array}{l}0 \\
6\end{array}$ & $\begin{array}{l}2 \\
8\end{array}$ & $\begin{array}{r}2 \\
3.0\end{array}$ \\
\hline Dimethoate & $\begin{array}{l}0.10 \\
0.20 \\
0.50\end{array}$ & $\begin{array}{r}4 \\
20 \\
58\end{array}$ & $\begin{array}{r}4 \\
22 \\
58\end{array}$ & $\begin{array}{r}4 \\
22 \\
60\end{array}$ \\
\hline Diazinone & $\begin{array}{l}0.05 \\
0.10 \\
0.20 \\
0.50\end{array}$ & $\begin{array}{r}0 \\
20 \\
30 \\
96\end{array}$ & $\begin{array}{r}2 \\
22 \\
36 \\
100\end{array}$ & $\begin{array}{r}4 \\
26 \\
36 \\
100\end{array}$ \\
\hline Sumithion & $\begin{array}{l}0.05 \\
0.10 \\
0.20 \\
0.50\end{array}$ & $\begin{array}{r}\mathbf{0} \\
2 \\
70 \\
92\end{array}$ & $\begin{array}{r}2 \\
4 \\
78 \\
100\end{array}$ & $\begin{array}{r}2 \\
8 \\
82 \\
100\end{array}$ \\
\hline Methyl parathion & $\begin{array}{l}0.012 \\
0.025 \\
0.050\end{array}$ & $\begin{array}{l}76 \\
80 \\
98\end{array}$ & $\begin{array}{r}78 \\
82 \\
100\end{array}$ & $\begin{array}{r}78 \\
86 \\
100\end{array}$ \\
\hline Formothion & $\begin{array}{l}0.20 \\
0.50\end{array}$ & $\begin{array}{l}0 \\
4\end{array}$ & $\begin{array}{l}2 \\
6\end{array}$ & $\begin{array}{l}2 \\
8\end{array}$ \\
\hline Elsun & $\begin{array}{l}0.20 \\
0.50\end{array}$ & $\begin{array}{l}2 \\
2\end{array}$ & $\begin{array}{l}4 \\
2\end{array}$ & $\begin{array}{l}4 \\
2\end{array}$ \\
\hline Sevin & $\begin{array}{l}0.05 \\
0.15\end{array}$ & $\begin{array}{l}4 \\
2\end{array}$ & $\begin{array}{l}4 \\
2\end{array}$ & $\begin{array}{l}4 \\
6\end{array}$ \\
\hline Akar & $\begin{array}{l}0.20 \\
0.40\end{array}$ & $\begin{array}{l}4 \\
2\end{array}$ & $\begin{array}{l}4 \\
2\end{array}$ & $\begin{array}{l}4 \\
2\end{array}$ \\
\hline Tedion & $\begin{array}{l}0.10 \\
0.15\end{array}$ & $\begin{array}{l}0 \\
0\end{array}$ & $\begin{array}{l}0 \\
0\end{array}$ & $\begin{array}{l}2 \\
2\end{array}$ \\
\hline CK & - & 0 & 0 & 0 \\
\hline
\end{tabular}

material. Another noticeable fact proved in this experiment is that the laboratory reared L. beneficus was more sensitive to pesticides than X. galactinus, while the field collected $\boldsymbol{L}$. beneficus was more tolerable than $\mathrm{X}$. galactinus.

For the cause of such higher sensitivity. of field collected individuals than laboratory reared ones, the age structure of field collected population may be at first taken into consideration. Namely, field collected adults are composed of various aged individuals. The variations of sensitivity against 7 insecticides in relation to the age were tested with the laboratory reared adults of both species (Table 70). Also the sensitivity against $0.05 \%$ sumithion in the various aged adults of $X$. galactinus is illustrated in Fig. 12.

Table 70 shows the significant increase of sensitivity to insecticides in older adults of both species. And the figure also demonstrates the linear 
Table 68. Effect of pesticides upon the mortality of field collected Lyctocoris beneficus.

\begin{tabular}{|c|c|c|c|c|}
\hline \multirow{2}{*}{ Pesticides } & \multirow{2}{*}{$\begin{array}{l}\text { Concentration } \\
\text { of effective } \\
\text { ingredient }(\%)\end{array}$} & \multicolumn{3}{|c|}{ Percent mortality } \\
\hline & & $12 \mathrm{hr}$ & $24 \mathrm{hr}$ & $48 \mathrm{hr}$ \\
\hline Dipterex & $\begin{array}{l}0.05 \\
0.10\end{array}$ & $\begin{array}{l}24 \\
48\end{array}$ & $\begin{array}{l}26 \\
48\end{array}$ & $\begin{array}{l}26 \\
48\end{array}$ \\
\hline Dimethoate & $\begin{array}{l}0.05 \\
0.10 \\
0.20\end{array}$ & $\begin{array}{l}18 \\
78 \\
94\end{array}$ & $\begin{array}{l}24 \\
80 \\
94\end{array}$ & $\begin{array}{l}24 \\
80 \\
94\end{array}$ \\
\hline Diazinone & $\begin{array}{l}0.05 \\
0.10\end{array}$ & $\begin{array}{l}62 \\
88\end{array}$ & $\begin{array}{l}62 \\
90\end{array}$ & $\begin{array}{l}64 \\
92\end{array}$ \\
\hline Sumithion & $\begin{array}{l}0.025 \\
0.050 \\
0.100\end{array}$ & $\begin{array}{r}52 \\
96 \\
100\end{array}$ & $\begin{array}{r}56 \\
96 \\
100\end{array}$ & $\begin{array}{r}56 \\
96 \\
100\end{array}$ \\
\hline Methyl parathion & $\begin{array}{l}0.012 \\
0.025\end{array}$ & $\begin{array}{l}100 \\
100\end{array}$ & $\begin{array}{l}100 \\
100\end{array}$ & $\begin{array}{l}100 \\
100\end{array}$ \\
\hline Formothion & $\begin{array}{l}0.05 \\
0.10\end{array}$ & $\begin{array}{l}12 \\
24\end{array}$ & $\begin{array}{l}14 \\
24\end{array}$ & $\begin{array}{l}14 \\
26\end{array}$ \\
\hline Elsun & $\begin{array}{l}0.05 \\
0.10 \\
0.20\end{array}$ & $\begin{array}{r}2 \\
12 \\
20\end{array}$ & $\begin{array}{r}2 \\
14 \\
24\end{array}$ & $\begin{array}{r}4 \\
14 \\
24\end{array}$ \\
\hline Sevin & $\begin{array}{l}0.025 \\
0.050\end{array}$ & $\begin{array}{r}2 \\
24\end{array}$ & $\begin{array}{r}4 \\
26\end{array}$ & $\begin{array}{r}4 \\
26\end{array}$ \\
\hline Akar & $\begin{array}{l}0.20 \\
0.40\end{array}$ & $\begin{array}{l}0 \\
2\end{array}$ & $\begin{array}{l}0 \\
2\end{array}$ & $\begin{array}{l}2 \\
2\end{array}$ \\
\hline Tedion & $\begin{array}{l}0.10 \\
0.15\end{array}$ & $\begin{array}{l}0 \\
2\end{array}$ & $\begin{array}{l}0 \\
2\end{array}$ & $\begin{array}{l}2 \\
2\end{array}$ \\
\hline CK & & 0 & 0 & 0 \\
\hline
\end{tabular}

increment of sensitivity in accordance with the age.

The nutritional condition of insects also gives certain influences on the tolerance against pesticides. As to this problem, a review was compiled by Gordon (1961). And it has become the general conception that well-fed insects have higher tolerance to pesticides. Although no further study concerning this aspect was conducted in the present work, the superiority of nutritional condition in the laboratory reared material to the field ones may be easily suggested by the presence of larger and heavier individuals in the former material. And this tendency is much more evidently pronounced in X. galactinus. Furthermore, the fact that the difference of sensitivity between the laboratory reared and field collected populations of L. beneficus is smaller than X. galactinus may be explained by the food condition in the field which seems more favourable to $\boldsymbol{L}$. beneficus than X.galactinus. The cause of such difference in the susceptibility of pesticides is presumably due to the season of their appearance too. Because, in many insects, the autumn generation is more nutritionally satisfied and have higher tolerance against the detrimental condition than the spring 
Table 69. Effect of pesticides upon the mortality of field collected Xylocoris galactinus.

\begin{tabular}{|c|c|c|c|c|}
\hline \multirow{2}{*}{ Pesticides } & \multirow{2}{*}{$\begin{array}{l}\text { Concentration } \\
\text { of effective } \\
\text { ingredient(s) }\end{array}$} & \multicolumn{3}{|c|}{ Percent mortality } \\
\hline & & $12 \mathrm{hr}$ & $24 \mathrm{hr}$ & $48 \mathrm{hr}$ \\
\hline Dipterex & $\begin{array}{l}0.05 \\
0.10 \\
0.20\end{array}$ & $\begin{array}{l}28 \\
54 \\
78\end{array}$ & $\begin{array}{l}28 \\
56 \\
82\end{array}$ & $\begin{array}{l}32 \\
56 \\
82\end{array}$ \\
\hline Dimethoate & $\begin{array}{l}0.05 \\
0.10 \\
0.20\end{array}$ & $\begin{array}{r}36 \\
100 \\
100\end{array}$ & $\begin{array}{r}38 \\
100 \\
100\end{array}$ & $\begin{array}{r}38 \\
100 \\
100\end{array}$ \\
\hline Di azinone & $\begin{array}{l}0.05 \\
0.10\end{array}$ & $\begin{array}{r}76 \\
100\end{array}$ & $\begin{array}{r}78 \\
100\end{array}$ & $\begin{array}{r}78 \\
100\end{array}$ \\
\hline Sumithion & $\begin{array}{l}0.025 \\
0.050 \\
0.100\end{array}$ & $\begin{array}{r}62 \\
100 \\
100\end{array}$ & $\begin{array}{r}68 \\
100 \\
100\end{array}$ & $\begin{array}{r}68 \\
100 \\
100\end{array}$ \\
\hline Methyl parathion & $\begin{array}{l}0.012 \\
0.025\end{array}$ & $\begin{array}{l}100 \\
100\end{array}$ & $\begin{array}{l}100 \\
100\end{array}$ & $\begin{array}{l}100 \\
100\end{array}$ \\
\hline Formothion & $\begin{array}{l}0.05 \\
0.10\end{array}$ & $\begin{array}{l}26 \\
40\end{array}$ & $\begin{array}{l}34 \\
44\end{array}$ & $\begin{array}{l}34 \\
46\end{array}$ \\
\hline Elsun & $\begin{array}{l}0.05 \\
0.10 \\
0.20\end{array}$ & $\begin{array}{r}4 \\
18 \\
36\end{array}$ & $\begin{array}{r}4 \\
18 \\
38\end{array}$ & $\begin{array}{r}8 \\
18 \\
40\end{array}$ \\
\hline Sevin & $\begin{array}{l}0.025 \\
0.050\end{array}$ & $\begin{array}{l}12 \\
56\end{array}$ & $\begin{array}{l}14 \\
58\end{array}$ & $\begin{array}{l}14 \\
58\end{array}$ \\
\hline Akar & $\begin{array}{l}0.20 \\
0.40\end{array}$ & $\begin{array}{l}4 \\
8\end{array}$ & $\begin{array}{l}4 \\
8\end{array}$ & $\begin{array}{l}6 \\
8\end{array}$ \\
\hline Tedion & $\begin{array}{l}0.10 \\
0.15\end{array}$ & $\begin{array}{l}2 \\
4\end{array}$ & $\begin{array}{l}4 \\
6\end{array}$ & $\begin{array}{l}4 \\
6\end{array}$ \\
\hline $\mathrm{CK}$ & - & 0 & 0 & 2 \\
\hline
\end{tabular}

generation (Rainwater 1951, Keiser et al. 1953, etc.).

The sensitivity of nymphs against sumithion was also examined using various stages of both species of bugs (Fig. 13). The result shows the increment of tolerance in accordance with the process of the development of nymphal stages. Sumithion of $0.05 \%$ solution was scarcely harmful to the 5th instar nymphs of both species, while the same dosage of the chemicals was certainly toxic to the young nymphs. In earlier nymphal stage, $L$. beneficus is slightly more sensitive than $X$.galactinus. But the difference in mortality between the two species was not observed in the 4 th and 5 th instars.

Tedion is widely used for the control of mites on various fruit plants and vegetables. Its acaricidal action concerns the prevention of their offspring. Therefore, the low mortality effect of this acaricide against Anthocorid bug is rather anticipated. Further, the toxicity of tedion against the eggs and young nymphs of the Anthocorid bug is unneglizible. To estimate the ovicidal action of this acaricide, tedion preparation of 
Table 70. Effects of pesticides upon the motalitty of 20-25 day old adults of Lyctocoris beneficus and Xylocoris galactinus, both of which are reared in the laboratory.

\begin{tabular}{|c|c|c|c|}
\hline Pesticides & $\begin{array}{l}\text { Concentration } \\
\text { of effective } \\
\text { ingredient }(\%)\end{array}$ & $\begin{array}{l}\text { Mortality a } \\
\text { L. beneficus }\end{array}$ & $\begin{array}{l}48 \mathrm{hr}(\%) \\
\mathbf{X} . \text { galactinus }\end{array}$ \\
\hline Dipterex & $\begin{array}{l}0.05 \\
0.10\end{array}$ & $\begin{array}{l}28 \\
44\end{array}$ & $\begin{array}{l}26 \\
28\end{array}$ \\
\hline Dimethoate & $\begin{array}{l}0.05 \\
0.10 \\
0.20\end{array}$ & $\begin{array}{l}14 \\
26 \\
68\end{array}$ & $\begin{array}{r}8 \\
12 \\
50\end{array}$ \\
\hline Sumithion & $\begin{array}{l}0.05 \\
0.10\end{array}$ & $\begin{array}{r}60 \\
100\end{array}$ & $\begin{array}{r}52 \\
100\end{array}$ \\
\hline Methyl parathion & $\begin{array}{l}0.012 \\
0.025\end{array}$ & $\begin{array}{l}100 \\
160\end{array}$ & $\begin{array}{l}100 \\
100\end{array}$ \\
\hline Formothion & $\begin{array}{l}0.20 \\
0.50\end{array}$ & $\begin{array}{l}24 \\
60\end{array}$ & $\begin{array}{l}12 \\
48\end{array}$ \\
\hline Elsun & $\begin{array}{l}0.20 \\
0.50\end{array}$ & $\begin{array}{r}34 \\
100\end{array}$ & $\begin{array}{r}22 \\
100\end{array}$ \\
\hline Sevin & $\begin{array}{l}0.025 \\
0.050\end{array}$ & $\begin{array}{l}28 \\
42\end{array}$ & $\begin{array}{l}24 \\
26\end{array}$ \\
\hline CK & - & 2 & 4 \\
\hline
\end{tabular}

conventional concentration, namely $0.01 \%$, was sprayed on the eggs which were laid on a filter paper. Then the rate of hatching of eggs and survivality of newly hatched nymphs were observed. The newly hatched nymphs remained on the treated filter paper for about 24 hours, then were placed to a clean petri-dish and reared with the larvae of T.castaneum.

The result of experiment reveals the uneffectiveness of tedion on the hatching rate of the eggs of both species. A slight detrimental effect was only observed on the eggs which were treated with tedion on the date of oviposition. But in this case, the rate of hatching still showed more than $70 \%$. This acaricide has no contact poisonous activity against the newly hatched nymphs, and the majority of young nymphs complete their growth. The acaricidal action of tedion is also known to produce invalid eggs by the treated female. The female treated with 0.1 and $0.15 \%$ solution of tedion laid many eggs which showed normal development.

In the present experiment, only parathion is extremely harmful against laboratory reared individuals, but parathion, sumithion, dipterex and diazinone against field collected individuals. But from the results of these experiments it is too early to conclude the safety of the other pesticides on the Anthocorid bugs. Actually under the field condition the bugs have few opportunities to make contact with such concentrated pesticidal preparations as used in this work. The exposure of Anthocorids for a fairly long period with the treated circumstance is a very important factor of 


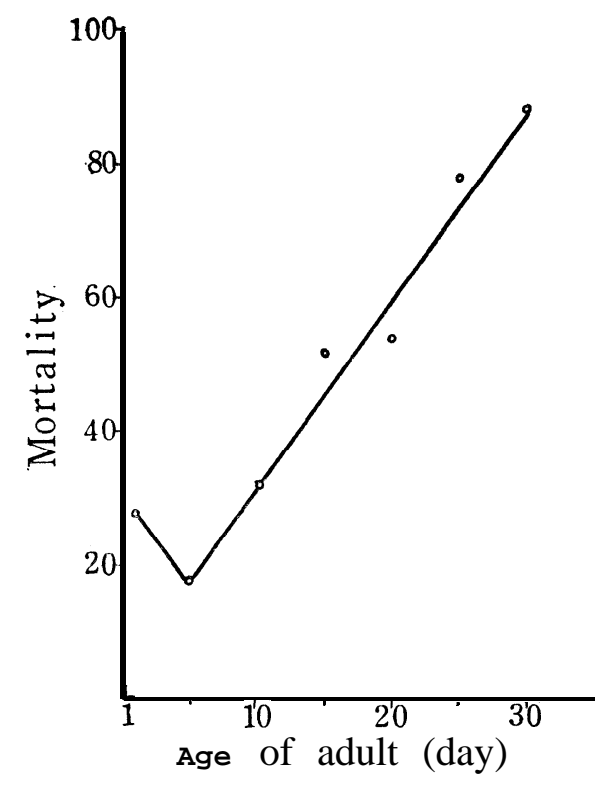

Fig. 12. Variation of sensitivity to $0.05 \%$ sumithion solution against the age of adult Xylocoris galactinus,

increasing the mortality. For example, 3 hour exposure to the filter paper which was treated with $0.1 \%$ sumithion solution gave more than $90 \%$ mortality against the young laboratory reared adult of $\mathrm{X}$. galactinus. Where-

as, the exposure of such solution for 1 hour gave only $2 \%$ mortality to the adult of the same condition. In another instance, $0.05 \%$ elsun solution which is scarcely harmful to the laboratory reared X. galactinus adult showed $100 \%$ mortality to the adult after 6 hour exposure. The bugs are generally acting as a rice stem borer controlling agent in a straw pile which is badly ventilated. When the pesticides is applied in such surroundings, the bugs are easily exposed to the pesticides for a comparatively long period, causing the higher mortality of the bugs. Of course the pesticide may induce the reduction of bug population and at the same time decrease the predatory effect against the rice stem borer. 


\section{Inter-specific competition between Lyctocoris beneficus} (Hiura) and Xylocoris galactinus (Fieber)

Competition between the species under the artificial and natural conditions has been investigated by numerous authors (Andrewartha and Birch 1960, DeBach 1966, etc.). Especially in predacious insects, the intra- and inter-specific cannibalism have been reported by many workers. For example, Wilde (1962) reported the cannibalism among the Anthocorid nymphs and Neuropterous larvae under the laboratory condition. In another example, McMullen and Jong (1967) suggested the competition among $A n$ thocoris spp., A. antevolens (White) and A. melanocerus (Reuter) and the other predacious insects. As they indicated clearly, the population of Anthocoris spp. increased in the DDT treated pear orchard. And they attributed the cause of the increase of the Anthocoris population to the reduction in numbers of the other predacious species such as Deraecoris brevis piceatus Knight, D. fasciolus Knight, Diaphnocoris provancheri (Burque), Chrysopa carnea Stephene, C. oculata Say, etc. The intraspecific cannibalism in the Anthocorid bugs was also pointed out by Barber (1936b) as "Orius insidiosus (Say) is cannibalistic, both as a nymph and as an adult. Adults fed upon nymphs, and females frequently feed upon males. The larger nymphs also devour smaller nymphs." A similar phenomenon in Anthocoris nemorum(Linné) was observed by Hill (1957). According to the author's preceding experiments, when Lyctocoris beneficus (Hiura) and Xylocoris galactinus (Fieber) are reared separately, the intraspecific cannibalism occurred only on the adults that devour their eggs. The cannibalism among adults and nymphs was only observed on the animal diet defficient or artificial diets provided condition. And it is an evident fact that the intraspecific cannibalism exists scarcely among the adults and nymphs of both species under the optimum condition.

The present work was made in an attempt to determine the occurrence of inter-specific competition between $L$. beneficus and X. galactinus. All the works were conducted under $30^{\circ} \mathrm{C}$ condition and the bugs tested were confined to a cylindrical petri-dish $(8 \times 8 \mathrm{~cm}$ in diameter and height) and provided with water soaked filter paper and dry cracked corn. Besides, to avoid the cannibalism caused by the starvation, sufficient prey, namely larvae of Tribolium castaneum (Herbst), were supplied.

To investigate the effect of one species on the young nymphs of another species, 10 of the first instar nymphs of one species were reared together with 10 individuals of variable developmental stages of another species. And the number of survivals was counted after 2 and 4 days (Table 71).

As seen in Table 71, the first instar nymphs of $\mathrm{X}$. galactinus were not 
Table 71. Number of survival of Lyctocoris beneficus and Xylocoris galactinus reared under an artificial condition (each petri dish contains 20 individuals, avg. of 5 replicates).

No. of survival

Combination

After 2 days

After 4 days
L. b.
x. g.
L. b. $\quad$ x. $g$.

L. b. (1st instar) +

X. g. (1st instar)

$7.6 \quad 8.6$

6.8

8.4

L. b. (3rd instarj +

X. g. (1st instar)

9.8

8.8

9.8

8.2

L. b. (adult) +

X. g. (1st instar)

10.0

8.4

9.4

7.8

L. b. (1st instar) +

X. g. (3rd instarj

5.4

10.0

3.6

10.0

L. b. (1st instar) +

X. g. (adult)

3.4

L. b. (1st instar)

9.4

10.0

$1.8 \quad 10.0$
0.9

X. g. (1st instar)

10.0

9.2

............

L.b. : $\mathbf{L}$. beneficus.

x. g.: X. galactinus.

influenced by the presence of either old nymphs or adults of L. beneficus. But the survival of young nymphs of L. beneficus was severely affected by the presence of individuals of X. galactinus. When the first instar nymphs of both species were reared together comparing with the result from the pure culture. The survival of X.galactinus was scarcely influenced, while L.beneficus significantly decreased in numbers of survived individuals as compared with the former.

In the second experiment, 20 first instar nymphs of both species were reared gregariously in a dish until all the tested nymphs became adults, counting the number of survived individuals continuously every other day, and the result was illustrated in Fig. 14.

Among the 20 first instar nymphs of $X$.galactinus, 14 individuals completed their nymphal development, while in L. beneficus only 5 nymphs became adults. For the cause of death of nymphs, the cannibalistic behaviour between the two species must be considered. But, no practical preying behaviour of X. galactinus on L. beneficus was observed at all. During the period of 22 days 12 individuals of L. beneficus were consumed for the first 6 days. This is equivalent to four-fifths the whole sacrified nymphs. This fact also indicates that first and second instar nymphs of L. beneficus 


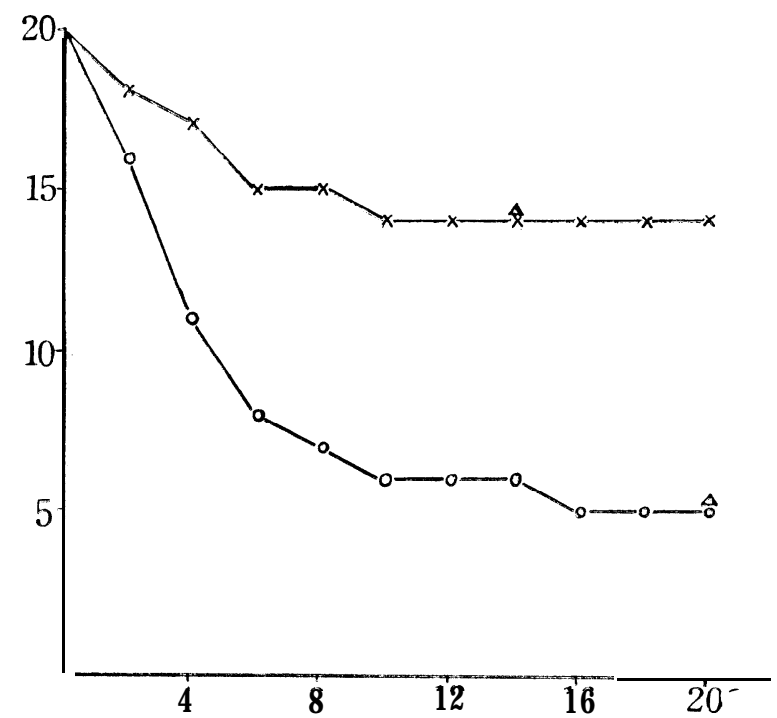

Fig. 14. Survival progression of Lyctocoris beneficus and Xylocoris galactinus (started with 20 1st instar nymphs): Abscissa, No. of bugs survived, ordinate, days.

--o-o- L. beneficus, ........ X. galactinus.

$\triangle$ shows the date when all individuals became adults.

are especially sensitive against the mixture of $X$. galactinus. The duration of nymphal stages given in Fig. 14 was 20 and 14 days in L. beneficus and $\mathrm{X}$. galactinus respectively. These values show little difference from that of the pure culture. The body weights of newly emerged adults were 1.4 and $2.1 \mathrm{mg}$ in X. galactinus and L. beneficus respectively. Compared these figures with that of the pure culture, no difference was seen in X. galactinus, but the value was evidently lighter in the case of $L$. beneficus.

The effect of mixed culture on the egg production was investigated using 10 pairs of both species which were emerged on the same day. In this test, the bugs were kept in a plastic tapper sized 13 x $10 \times 7 \mathrm{~cm}$ (length $\mathrm{x}$ width $\times$ height) and provided with moist filter paper, dry cracked corn and sufficient prey (Table 72).

The duration of pre-oviposition period was scarcely influenced in both species, being 7 and 5 days in minimum value in L. beneficus and X. galactinus respectively. The egg production was studied by counting the numbers of eggs deposited on the filter paper and the results are given in Table 72 and Fig. 15.

Although the mixed culture did not influence the duration of pre-oviposition period in both species, the oviposition period of $L$. beneficus was seriously affected by the presence of $X$. galactinus. And in the former species, 
Table 72. Effect of mixed culture on the egg production of Lyctocoris beneficus and Xylocoris galactinus (data from 10 pairs of adults).

\begin{tabular}{|c|c|c|c|c|c|c|}
\hline & & \multirow{2}{*}{$\begin{array}{l}\text { Pre-ovipo- } \\
\text { sition } \\
\text { period } \\
\text { (minimum) }\end{array}$} & \multirow{2}{*}{$\begin{array}{l}\text { Oviposi- } \\
\text { tion } \\
\text { period } \\
\text { (maximum) }\end{array}$} & \multirow[t]{2}{*}{$\underset{\text { female }}{\text { Eggs per }}$} & \multicolumn{2}{|c|}{$\begin{array}{l}\text { No. of adults } \\
\mathbf{1 0} \text { days after } \\
\text { emergence }\end{array}$} \\
\hline & & & & & $\sigma^{\lambda}$ & 우 \\
\hline L. beneficus & $\begin{array}{l}\text { pure } \\
\text { mixed }\end{array}$ & $\begin{array}{l}7 \\
7\end{array}$ & $\begin{array}{l}28 \\
10\end{array}$ & $\begin{array}{l}34.6 \\
12.3\end{array}$ & $\begin{array}{l}7 \\
5\end{array}$ & $\begin{array}{l}9 \\
6\end{array}$ \\
\hline$X$. galactinus & $\begin{array}{l}\text { pure } \\
\text { mixed }\end{array}$ & $\begin{array}{l}4 \\
5\end{array}$ & $\begin{array}{l}23 \\
24\end{array}$ & $\begin{array}{l}39.2 \\
30.5\end{array}$ & $\begin{array}{l}5 \\
7\end{array}$ & $\begin{array}{l}8 \\
7\end{array}$ \\
\hline
\end{tabular}

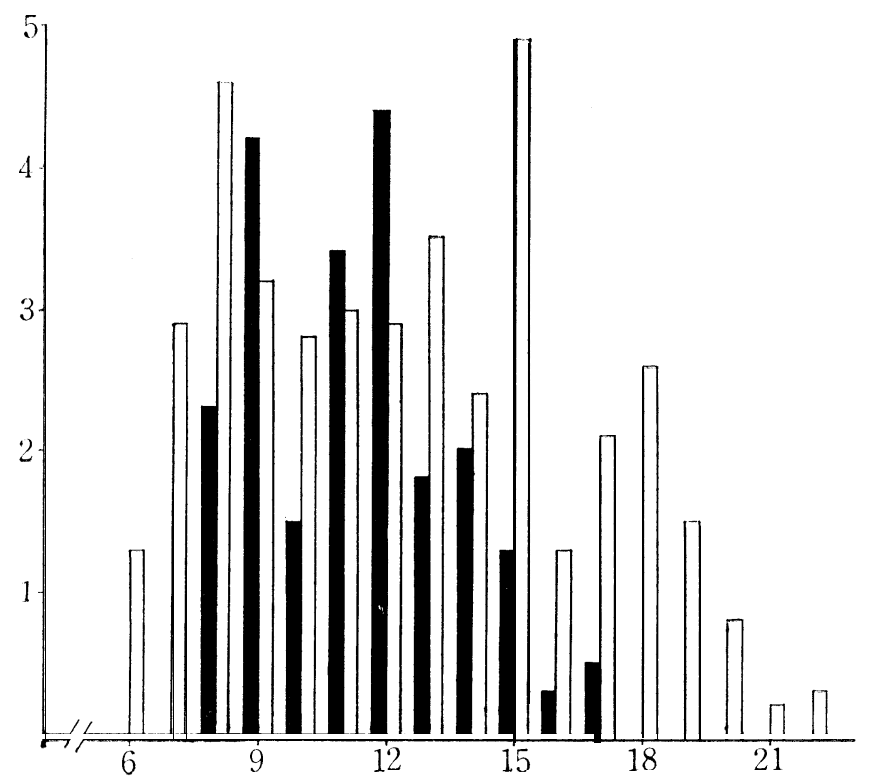

Fig. 15. Egg production in the mixed culture of Lyctocoris beneficus and Xylocoris galactinus: Abscissa, No. of eggs per female, ordinate, days after emergence. $\mathrm{L}$. beneficus. $\square \mid X$. galactinus.

the egg deposition almost stopped within a week and the number of deposited eggs decreased to about one-third of the pure culture. On the contrary, egg production of $X$. galactinus in the mixed culture was scarcely affected by L. beneficus. The eggs of both species showed some high degree of hatching ability and this fact may indicate that the copulation was not affected by the mixed culture. In the mixed culture, the male $X$. galactinus sometimes mounted on the female L. beneficus and tried to make copulation. However, the apparent difference in body size always prevented their copulation. On the other hand, the author has never observed the male L. beneficus 
mounting on the female X. galactinus. Though the accurate longevity of tested adults was not ascertained, the number of adults survived 10 days after the emergence indicates the shortened longevity of $L$. beneficus in the mixed culture.

In conclusion, when L.beneficus and X. galactinus are reared together, $L$. beneficus is overwhelmed by $\mathrm{X}$. galactinus in every aspect of life activities, especially either the survival of young nymphs or egg production. In fact, under the insectarium condition, when $X$. galactinus invades into $L$. beneficus culture, the offspring production of $L$. beneficus is heavily influenced and only a few new progeny of $L$. beneficus are obtained from such a contaminated culture, and within certain periods, the culture is entirely replaced by the invader. In the field condition, although the habitats of both species are very similar to each other, the author has never seen the cases in which the two species co-existed in larger numbers in the same habitat.

\section{Co-existence with Apanteles chilonis [Munakata]}

A Braconid wasp, Apanteles chilonis [Munakata] is one of the most important larval parasites of the rice stem borer in Japan. The availability of this parasite as the controlling agent against the rice stem borer is already pointed out by several workers (Gyotoku 1960, Tateishi 1962, Yasumatsu 1964, 1967, Deloach and Miyatake 1966, etc.). As both Lyctocoris beneficus (Hiura) and Xylocoris galactinus (Fieber) also devour the larvae of rice stem borer, the study on the inter-relationship between these natural enemies is very important in deciding the effect of natural enemies on the control of rice stem borer in the field condition.

For the rearing method of the parasites, about 10 of newly emerged $A$. chilonis adults were confined to a large test tube which was $20 \times 3 \mathrm{~cm}$ (length and diameter) in size, providing with water soaked cotton and bee honey. Besides, 3 mature larvae of Chilo suppressalis (Walker) were afforded for the oviposition of the parasite. The rice stem borers were readily received the oviposition by the parasites. The borer was changed to new ones every dav. The parasitized borers were kept in another test tube in which the paddy straw was afforded under $25^{\circ} \mathrm{C}$ condition. After $15-16$ days, about 20 mature larvae of parasites were escaped from the body of borer and make white small cocoons. Three to four days after pupation the adults emerged. The percent of parasitization was certainly high, being about $80-90$ percent.

To test the inter-relationship with the Anthocorid predator, some parasitized borers were placed in a $100 \mathrm{ml}$ beaker into which 10 or 20 adults of $L$. beneficus or X. galactinus were confined. Parts of parasitized larvae were attacked by the predators soon, while some of the borers were attacked after several days. The investigation on the attacked larvae was conduct- 
ed twice a day and the borers bearing a pierced puncture were removed from the beaker and observed the further development. Usually, the attacked borers died within 48 hours, and finally became black dwindled corpse. No larvae of parasites were of course escaped from the attacked borers even from the individuals which were parasitized 15 days ago. In the bug container, some mature larvae of parasites came out from the borers which were fortunately escaped the attack of predators. But majority of such mature larvae were readily preyed by the bugs. The predators prefered to prey the larvae of parasites to the borers. Although some mature larvae were seen to succeed to make cocoons, the bugs sucked the blood of larvae through the wall of cocoons, and thus the adult parasites seldom emerged in the bug container.

On the other hand, if the bug-attacked borers were provided for oviposition of A. chilonis, then the ovipositional behaviour of the wasp was observed. But all the borers died within 48 hours after the attack by predators, and of course no parasite was developed from those pierced borers. In this case, the parasitization does not seem to accelerate the death of the pierced borers.

Next, the unparasitized borers and those parasitized 3,6,9,12 and 15 days bofore were marked with magic ink and 5 individuals of each group were put together in a plastic tapper (14 x $10 \times 6 \mathrm{~cm}$ in long, wide and high) in which about 50 or 100 of L. beneficus or X. galactinus were supplied. Then the preference of attack by the predators was checked at 2 day interval (Fig. 16).

The experiment indicates that more than $70 \%$ of the attacked larvae belonged to the individuals of the earlier parasitized borers. The parasitized larvae in this stage were apparently more sluggish than the normal or newly parasitized individuals. Therefore, they were more easily accepted by the predators.

In conclusion, both L.beneficus and $X$. galactinus are directly or indirectly fatal agents to A. chilonis, and the Anthocorid bugs always eliminate Apanteles wasps in the laboratory condition. Although no field survey is conducted as yet, the similar tendency may be conceivable when and where the Anthocorid bugs

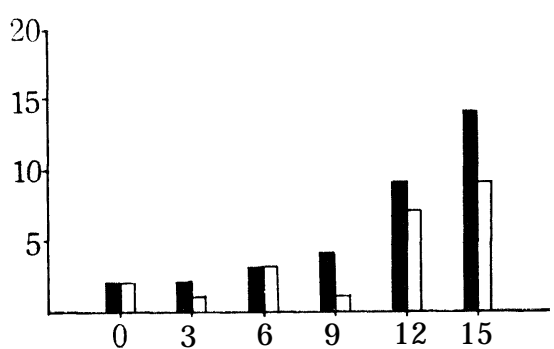

Fig. 16. Number of attacked borers by Lyctocoris beneficus and Xylocoris galactinus. The borers were containing various stage larvae of Apanteles chilonis ; Abscissa, No. of borers attacked, ordinate, days after parasitization.

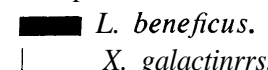
are abundant in the environment. 


\section{Approach to the mass production}

The availability of the two bugs as the predators against the rice stem borer was proved in the present work. Therefore, the next necessary step of study is the mass production procedure of these bugs.

\section{Culture media and rearing method.}

Two kinds of material are advisable for the culture media of the Anthocorid bugs. One is the moist vermiculite and another is the molded cracked corn. The moist vermiculite is prepared to add $15 \mathrm{ml}$ of water into $100 \mathrm{~g}$ of vermiculite - rough vermiculite is preferable - the growth of bugs is better on the molded vermiculite. The preparation of the molded vermiculite is not difficult. It is easily obtained by adding small amount of wheat flour into the moist vermiculite, then the Tribolium larvae can survive for a longer period so long as the food is available.

The molded cracked corn is generally superior to the vermiculite medium both for the offspring production and development of bugs, especially in the case of L. beneficus. But it is rather a difficult problem for this medium to prevent its excess fermentation without making any injurious effects on the development of mold and bugs. Such Lepidopterous insect pests as meal moth (Plodia interpunctella (Hiibner)), grain moth (Aphomia gularis (Zeller)), almond moth (Cadracautella (Walker)) etc. are harmful to the bugs. The infestation of these pests is easily prevented by the autoclaving of corn before the mold cultivation. Another difficulty in the corn medium is the outbreak of mites, for example, grain mite (Acarus siro Linné) and Tyrophagus dimidiatus Herman. Though the mites are excellent food for the bugs especially for young nymphs, the mites also damage bug's eggs, and usually very few nymphs of bugs hatch from the mite contaminated media. In the rearing either with vermiculite or molded corn medium, the bugs oviposite eggs in the media and newly hatched nymphs grow on it. The co-existence of the adults gives very little influences on the growth and survival of nymphs. The maintenance of water content in culture media is very important both for the existence and oviposition of bugs, especially for the latter activity. Further, the drying condition of media substrata is fatal to the hatching ability of eggs on it. The humidity of media should be inspected at least every 2--3 days, and supply some water if necessary.

Although the following method is more time-consuming than the above mentioned methods, higher efficiency of off-spring production is obtained by this method especially in the case of L. beneficus. Namely, the bugs are reared in the dry cracked corn or dry vermiculite and the wet filter paper is provided in the rearing container as an oviposition substratum. 
Then, the majority of eggs are deposited on the provided filter paper. However, in this case attention should be paid to the prevention of eggpredatism by the adult bugs. Thus, papers should be exchanged to new ones at least twice a day. The presence of eggs is easily visible by the naked eyes, and the papers containing deposited eggs are placed on wet vermiculite. The filter paper should keep certain humidity during the incubation period of eggs, but too much water supply is harmful to eggs. When the eggs change in colour to pinkish and the time of hatching becomes near, it is necessary to provide some amount of Tribolium culture medium and premature larvae of $\mathbf{T}$. castaneum. The occasional addition of medium is very important both for the survival of $\mathbf{T}$. castaneum larvae and the keeping of mold on the medium. The mortality of newly hatched nymph is always kept low in moderately molded media. After hatching, the food and water should be supplied occasionally to the rearing media. When the nymphs grow to the last instar, the nymphs are better to be removed from the vermiculite medium to the dry cracked corn medium. Of course, the vermiculite medium is also suited for adult breeding. Always the rearing process is preferable to be carried out under $30^{\circ} \mathrm{C}$ condition. The illumination of more than 12 hours per day gives bad influence on the growth of bugs, and the rearing in the dark chamber of incubator showed satisfactory result. The three methods mentioned above are recommendable for the rearing of both species, and especially the mass production of $\mathrm{X}$. galactinus was found to be very successful.

For the mass-culture of the bugs, the author mainly used $12 \times 12 \times 12 \mathrm{~cm}$ (in length, width and height each) plastic tapper which is containing $1 \mathrm{~cm}$ depth of culture medium. About 10 or 20 pairs of L. beneficus or X. galactinus adults may be kept in it respectively.

\section{Food.}

According to the author's work, it was proved that the larvae of red flour beetle (Tribolium castaneum (Herbst)) were the most suitable food for both species of bugs. As it is a cosmopolitan stored-grain insect pest and able to be reared with any of the wide varieties of foodstuffs. Therefore, voluminous studies have been done by many workers on this beetle. Its systematic and morphological studies were conducted by Hinton(1948), Mertz (1961), Ho (1967) etc., and the studies of its biology were accomplished by Good (1933, 1936), Howe (1956, 1960), Khalifa and Badawy (1955a, b), Sinha and Mookhewee (1967), etc. The method of mass culture was developed by Harein and Soderstrom (1966) and Qureshi (19661). The method of the former authors was established at Savannah laboratory in U. S. A., using white flour and corn meal (47.5\% each) and brewer's yeast $(5.0 \%)$ for culture medium, while the latter author used a mixture of whole wheat flour, powdered milk and dried yeast. 
The present author collected the adults of $T$. castaneum at the stock yard of Kyushu University. Though he did not use "Triboliotrap" which was designed by Stanley (1962), it may be available for the collection of the Tribolium beetles. The rearing and propagation of the beetles were carried out by the following method: About 500 individuals of both male and female were released in a $15 \times 20 \mathrm{~cm}$ (in diameter and height) glass cylinder which contained about $250 \mathrm{~cm}^{3}$ of powdered rat food and wheat short flour $(2: 1 \mathrm{v} / \mathrm{v})$. Thus, the food was occupying the bottom of the cylinder about $4 \mathrm{~cm}$ thick. After 5 day rearing, the adults were separated from the medium by sieving. The adults were transfered to a new medium for further oviposition. The sieved medium which contained eggs and young nymphs of beetle was placed in a $6 \times 22 \times 40 \mathrm{~cm}$ (in height, width and length) carton box. Then 400-500 mature larvae were obtained 20-23 days after sieving. The results of rearing with the powdered rat food plus wheat short flour medium were quite excellent and superior to the results obtained from some other media (Table 73).

Table 73. Growth of Tribolium castaneum in various media under $30^{\circ} \mathrm{C}$ (average of about 50 individuals).

\begin{tabular}{lcc}
\hline \multicolumn{1}{c}{ Media } & $\begin{array}{c}\text { Larval stage } \\
\text { (in days) }\end{array}$ & $\begin{array}{c}\text { Weight of mature } \\
\text { larvae (in mg) }\end{array}$ \\
Rat food + wheat short flour & 25.3 & 3.5 \\
$\begin{array}{l}(1: 1 \mathrm{v} / \mathrm{v}) \\
\text { Wheat short flour }\end{array}$ & 30.4 & 3.4 \\
Refined flour+yeast $(95: 5 \mathrm{w} / \mathrm{w})$ & 28.8 & 3.1 \\
Refined flour & 92.5 & 3.2 \\
\hline
\end{tabular}

The mature larvae were readily separated from media by sieving with a 25 mesh sieve. For the separation and inspection of larval growth and population, Saunder's method was also advisable (Saunders and Kruger 1957). All the breeding works were performed under $30^{\circ} \mathrm{C}$ condition, while the temperature of $33^{\circ} \mathrm{C}$ was more preferable.

The renewal of oviposition and feeding media of adults every several days was very important for the mass-production of the beetle, because adults have a predacious habit against their own eggs (Boyce 1946, Sonleither 1961). The adult beetle is also predacious on the eggs of Anthocorid bugs laid in the bug-culture media, but less harmful to the eggs which are laid on the filter paper. The presence of adult beetles in the bug's media gives no bad effect on the growth of adult and nymphal bugs. Therefore, the supply of numerous mature larvae of the beetle to the bug-culture media at one time should be avoided, and it is a rather preferable method to provide premature larvae instead of mature ones. The removal of the adult beetles from the bug's media is an important pro- 
cedure especially to protect bug's eggs which were laid in the culture media.

\section{ITT. Collection of bugs from the culture media.}

This work is easily conducted by pouring the whole medium on the white-coloured plate, and shaking the plate gently. Then the adults and mature nymphs leave the medium readily and will be collected by an aspirator. This work is preferably to be done under the warmer condition, higher than $25^{\circ} \mathrm{C}$, as under the cooler condition the bugs become too inactive to be collected. The percentage of collection of bugs by this method was tested by using 100 individuals which were composed of both adults and various stages of nymphs. And the number of collected bugs during 5 minutes from $288 \mathrm{~cm}$ " of culture medium that corresponds to the contents of two rearing plastic tappers is given in the following Table 74 .

Table 74. Percent collection of bugs from the media by pouring method within $\mathbf{5}$ min work.

\begin{tabular}{|c|c|c|c|c|}
\hline \multirow{2}{*}{ · } & \multicolumn{2}{|c|}{ Adult and old nymph } & \multicolumn{2}{|c|}{ Young nymph } \\
\hline & L. beneficus & $X$. galactinus & L. beneficus & $X$. galactinus \\
\hline Vermiculite & 96.3 & 94.1 & 64.3 & 55.2 \\
\hline Molded corn & 85.6 & 82.8 & 47.5 & 36.7 \\
\hline Dry corn & 98.0 & 96.5 & 71.6 & 68.2 \\
\hline
\end{tabular}

As seen in the table given above, more than 80 percent of adults and mature nymphs of both species were collected by a short time handling. While the collection of young individuals of both species was always low in any kinds of media. The separation of young individuals or eggs from the culture media is time consuming or almost impossible. Therefore, it is better to keep the media in the rearing condition for additional several days after the first separation and conduct the second separation when the remained nymphs become the matured nymphs or adults. This separation work is more easily conducted if the culture media are spread on the cloth on the bottom of the cabinet, especially in the treatment of the more active species, L. beneficus.

\section{Attack of bugs to man}

As in the case of the other groups of Heteropterous bugs, the Anthocorid bugs sometimes attack man and suck blood. The biting records of the Anthocorid bugs were previously made by some workers, and the bugs are also dealt as injurious insects of minor medical importance in some 
text-books (Riley and Johannsen 1936, Martini 1946, Matheson 1950, Shiraki 1958 , etc.). In spite of the blood sucking habit, the bugs are normally recognized as beneficial predators against injurious insects. Up to the present, the following bugs have been reported as blood sucking agents.

Anthocoris congolensis Brumpt (Shiraki 1958)

A. kingi Brumpt (Lewis 1958)

A. musculus Say (Torre-Bueno 1931)

A. nemorum (Linné) (Matheson 1950)

Lyctocoris campestris (Fabricius) (Woodward 1951, Stys and Daniel 1957)

Orius insidiosus (Say) (Tucker 1911, Malloch 1916, Myers 1926j

O.tantilus (Motschulsky) (Misra 1924, Myers 1926)

Xylocoris afer (Reuter) (Lewis 1958)

The case of attacking by Lyctocoris beneficus (Hiura) and Xylocoris galactinus (Fieber) has not been recorded. During the author's field work with these bugs, he has experienced their attack very rarely. The attack is slightly more painful than that by some leafhoppers such as Nephotetix cincticeps (Uhler). The sucked spot becomes red and swollen but without itching as mosquitos-bite and the sore does not remain for a long period. The sucking is encountered in the hot summer season. Anyway, the bugs are nothing but facultative or accidental blood suckers as the other Anthocorid bugs. Therefore, considering their usefulness as the predators of rice stem borers and the other insect pests, such attack against man may be regarded as a permissible fault to the side of the bugs.

\section{Conclusion}

\section{Evaluation of bugs as the predators against the rice stem borer}

The possibility of utilizing Lyctocoris beneficus (Hiura) as a controlling agent against the rice stem borer (Chilo suppressalis (Walker)) is already pointed out by some workers (Oho 1955a, b, c, Bess 1967, Yasumatsu 1967, etc.). And the predatory effect of L. beneficus and Xylocoris galactinus (Fieber) is also proved by the present work. Although the number of prey attacked by a single bug is very much variable with some factors including the population density of the predator itself or the host, etc., the daily attacked rice stem borer numbers are approximately 0.32 and 0.24 for the adult $L$. beneficus and $X$.galactinus respectively. But these data were obtained under the environment where no shelter was provided for the prey and predator, and the predator was directly in contact with the prey. Therefore, such condition may differ in many respects from the natural circumstances where the bugs are playing an important role as the controlling agents against the borers. As the preying amount and feeding be- 
haviour of bugs are easily influenced by some environmental factors, the preying behaviour of the two Anthocorids against the borers was investigated under the various temperature, illumination and straw conditions for the purpose of making further evaluation of the effect of bugs as the borer predators. Dry and moist paddy straws were provided in $50 \mathrm{ml}$ beakers separately, and to each beaker were released 5 borers, and 10 or 20 adults of $L$. beneficus or X. galactinus respectively. Besides, for the sake of control, some beakers were only provided with the borers and bugs without putting any straw. Then parts of beakers were placed in a dark chamber of an incubator, the temperature being kept $30^{\circ} \mathrm{C}$ constantly, and the other groups of beakers were placed under $25^{\circ} \mathrm{C}$ condition. In the $25^{\circ} \mathrm{C}$ group, half of beakers were placed under the dark condition and the remaining half placed under the illumination of 12 hours per day. Each tested group was consisted of 5 beakers and the number of survived bugs and borers were counted on the fifth day from the start of the experiment (Tables $75 \& 76)$.

Table 75. Number of rice stem borers consumed by Lyctocorisbeneficus under various conditions during 5 days.

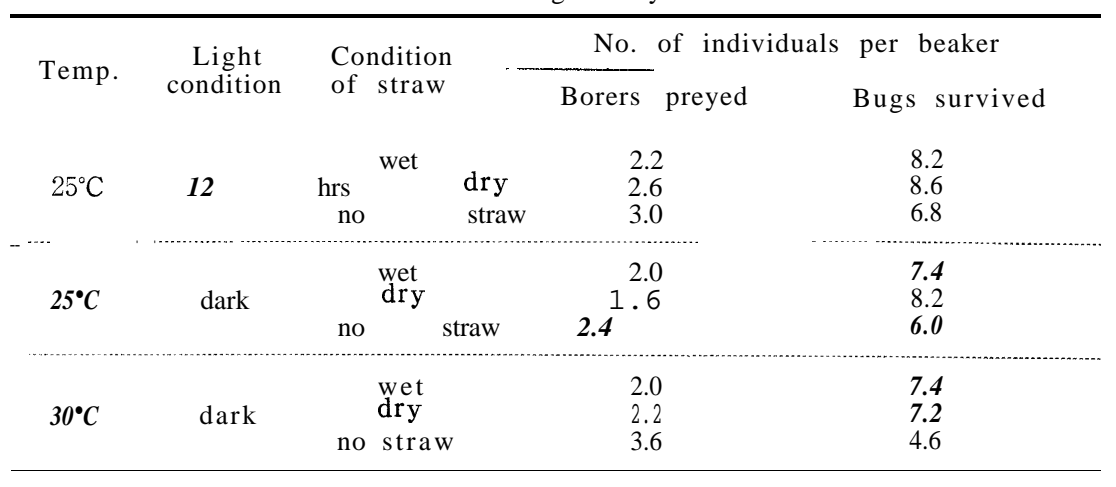

Table 76. Number of rice stem borers consumed by Xylocoris galactinus under various conditions during 5 days.

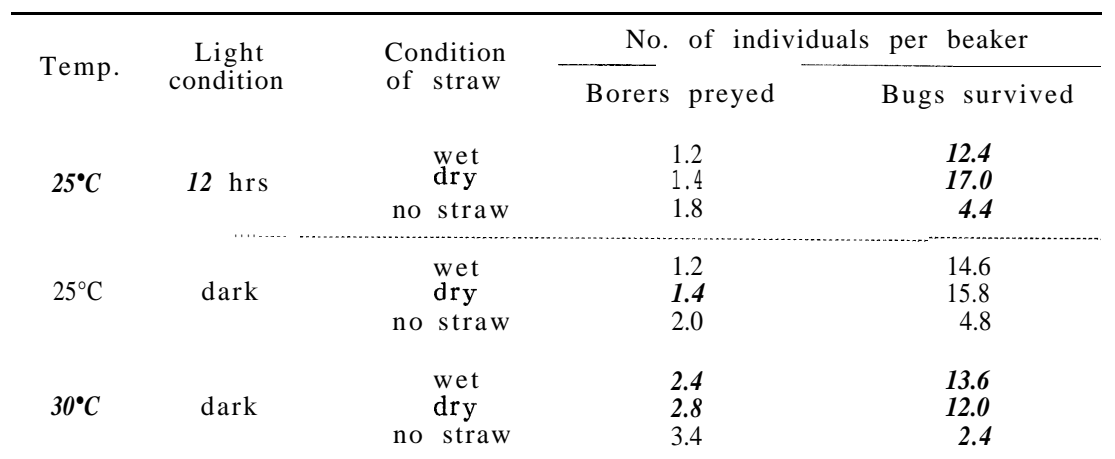


As seen in Tables 75 and 76 , the highest preying records were obtained in the no straw group in both species. This is probably due to the easier accessibility of predators to prey. But, in this group the mortality of bugs was also apparently higher than the straw provided group. This tendency was more pronounced in $X$. galactinus and it is perhaps partly attributed to the crush of bugs by the movements of borers when the prey are attacked by the bugs, and also partly due to the cannibalism between the bugs. But no actual cannibalism was observed. Although the number of preyed borers decreased in the straw provided group, the survival of bugs increased. The killed borers were observed both at the outside and inside of the provided straw. The borers found at the outside of the straw might have been attacked when they were at the outside, or might have escaped from the straw after receiving the piercing of the bugs. Under the normal condition all the borers were in the straws provided. Therefore, the latter case is seemingly more possible. In the straw provided beakers, bugs were almost found under the outermost leaf sheath, and some individuals were also found in the pith of straw. Moreover, a part of bugs were invaded into the pith of straw, the opening of which was covered with the layer of borer's excreta. Only few bugs were found on the surface of straw. In a part of attacked borers, pierced punctures were observed on the posterior part of the trunk. This is rather indicating that these borers were attacked'in the straw. The low mortality of bugs in the straw provided group is due to the restriction of borer's activity by the narrowness of the inside of straw, and from this reason, the prey are easily attacked by the bugs without receiving any resistance from the borers. In some straw provided beakers no borers were preyed, but the survival of bugs was certainly high. This fact may suggest that the straw seems to contain some nutritional components which can maintain the life of bugs for a certain period. The higher mortality of bugs was obtained in the moist straw than in dry ones, but this may be caused by the drowning of bugs by the excess of water drops on the inner surface of straw and beaker. On the other hand, moderate moist of straw is indispensable for the bugs to keep high survival rate. The preying amount was slightly higher in the dry straw than in the moist one. The illumination condition seems to stimulate slightly the preying activity of L.beneficus, but as the majority of bugs are dwelling in the straw, the light condition seems to be ineffective on the activity of bugs. The light condition seems to have no connection to the feeding activity of $X$. galactinus. Concerning the temperature, feeding amount increased in warmer conditions and this tendency was especially pronounced in X.galactinus. For the further observation on these tested straw, some young nymphs were hatched from the tested moist straw, but not from dry straw.

The preying activity of bug nymphs against the borers was also investigated using 2 day old individuals. The experiments were divided into 
three: 1) 50 nymphs, 2) 50 nymphs+20 borers and 3) 50 nymphs+20 adult bugs +20 borers. The plastic tapper of $13 \times 10 \times 6 \mathrm{~cm}$ in size (length $\mathrm{x}$ width $x$ height) was provided with slightly moist straw, and in these tappers three kinds of experiments mentioned above were performed. The survival of tested bugs was counted after 10 days rearing (Table 77).

Table 77. Effect of predation of 2 day old bug nymphs on the rice stem borer (data obtained after 10 days).

\begin{tabular}{|c|c|c|c|c|}
\hline \multirow[b]{3}{*}{$\begin{array}{l}50 \text { nymphs } \\
+20 \text { adults } \\
+20 \text { borers }\end{array}$} & \multirow{2}{*}{\multicolumn{2}{|c|}{$\begin{array}{l}\text { No. of survival of } \\
\text { L. beneficus } \\
\text { - Nymph Adult }\end{array}$}} & \multirow{2}{*}{\multicolumn{2}{|c|}{$\begin{array}{l}\text { No. of survival of } \\
\frac{X . \text { galactinus }}{\text { Nymph Adult }} \text { Borer }\end{array}$}} \\
\hline & & & & \\
\hline & 34 & 12 & 24 & 14 \\
\hline $\begin{array}{l}50 \text { nymphs } \\
+\quad 20 \text { borers }\end{array}$ & 35 & 7 & 36 & 10 \\
\hline 50 nymphs & 17 & - & 14 & $-\quad-$ \\
\hline
\end{tabular}

As seen in Table 77, the preying activity of both species against the borers was apparently high in the group without adult. Although the young instar bug individuals hardly attack the freely crawling borers, the present work showed the predation of borers by the young instar nymphs under the straw provided condition. In the group with adult bugs, however, the number of bugs in a tapper increased by the addition of 20 adults. But, on the contrary, the preying amount of the borers decreased. In this case, the survival of adults was however extremely high, and high nymphal mortality was also observed. The decrease of nymphal population may presumably be attributed to the adult feeding upon the nymphs instead of borers. The predation of nymphs by the adults was apparently less in L. beneficus than in $X$. galactinus. In the adult added group, some newly hatched young nymphs which were evidently produced from the eggs deposited by the provided adults were observed. In the group provided with straw only, the survival of nymphs was the lowest of the three tested groups and this is undoubtedly due to the cannibalism between the nymphs induced by the shortage of animal diets. Although the survival of nymphs was not high in the adult added group, part of nymphs survived and developed to adults. Under such a condition the bugs could survive generation after generation, and actually the population of bugs increased gradually.

The preying activity against the overwintering borers in the paddy stubbles was investigated with the stubbles harbouring borers. Therefore, 10 or 20 adults of L. beneficus and X.galactinus were liberated into a paddy 
stubble which was previously provided with 10 mature borers. The tested stubbles were entirely covered with a glass cylinder and organdy cloth to prevent the escape of predators and borers. These stubbles were placed under $25^{\circ} \mathrm{C}$ condition with 12 hour illumination a day, and the number of survived individuals was counted by the dissection of 5 stubbles every 2 days (Table 78).

Table 78. Preying effect of Lyctocoris beneficus and Xylocoris galactinus against the rice stem borers in the paddy stubbles.

\begin{tabular}{cccccc}
\hline $\begin{array}{l}\text { Days from } \\
\text { inoculation }\end{array}$ & \multicolumn{2}{c}{ No. of survival } & \multicolumn{2}{c}{$\begin{array}{c}\text { No. of survival } \\
\text { of }\end{array}$} \\
$\mathbf{0}$ & Borer & L. beneficus & Borer & X. galactinus \\
\cline { 4 - 5 } 2 & 10.0 & $\mathbf{1 0 . 0}$ & 10.0 & 20.0 \\
4 & 8.8 & 8.2 & 9.2 & 17.2 \\
6 & 8.6 & 8.4 & 9.0 & 16.4 \\
8 & 7.8 & 7.0 & 8.4 & 14.4 \\
10 & 7.6 & 5.4 & 8.8 & 12.0 \\
\hline
\end{tabular}

Comparison of the results in Tables 75 and 76 shows that the largest difference is characterized by the decrease of preying amount of the borers. For the cause of the decrease of food consumption, it should be taken into consideration that, in the preceding experiment, the environment of predators is only consisted of straw and borer. But in this work, there were found some small-sized Dipterous, Coleopterous and Collembolous insects amidst the tillers and on the soil, and these small creatures were undoubtedly regarded as preferable foods. Although some bugs were found amidst the tillers or inside of the straw, about half of the liberated bugs were recovered from the surface of the soil. And the latter individuals were roving on the soil surface presumably seeking for small insects. On the contrary, all the provided borers entered into the stubbles. Therefore these surface staying bugs did not contribute to control the borers. Some newly hatched nymphs were observed inside the stubbles 8 days in $L$. beneficus and 6 days in $\boldsymbol{X}$. galactinus after the liberation of their adults. Another difference from straw provided test was that majority of the attacked borers died at the outside of the stubbles.

From the above results, L. beneficus and X. galactinus may be considered as effective natural enemies to check the overwintering borers in the straw and stubbles, and the control is more effective against the straw dwelling borers. As these predators are polyphagous, the preying effect against the rice stem borer may be greatly influenced by the fauna of the environment, especially by the presence of some small-sized creatures. Al- 
though Oho (1955a, b) reported the $90 \%$ mortality of rice stem borers by L. beneficus, this data might be obtained from somewhat specially conditioned straw piles. As these predators do not attack exclusively the rice stem borers and their attacks are frequently concentrated to some other smallsized and soft-bodied animals. Therefore, the occurrence of these animals may greatly reduce the possibility of attacking the borers.

Anyway, it is apparent that under certain conditions these predators may prey on the rice stem borers effectively, and the attacked borers may almost absolutely receive fatal damage. For this reason, both $L$. beneficus and X. galactinus are considered to be effective natural enemies in checking the rice stem borer population.

\section{Summary}

The present work was undertaken to make clear the bionomics of two Anthocorid bugs, Lyctocoris beneficus (Hiura) and Xylocoris galactinus (Fieber), with special reference to the possibility of utilizing these species as the controlling agents against the rice stem borer.

Both species are commonly found in the giant straw piles, warehouses and also in the field.

The rearing of two species was conducted in the laboratory under the constant temperature conditions of $25^{\circ} \mathrm{C}, 30^{\circ} \mathrm{C}$ and $33^{\circ} \mathrm{C}$. The lengths of egg, nymphal and adult stages at $30^{\circ} \mathrm{C}$ are 4,20 and 31 days in $\mathrm{L}$. beneficus and 3,13 and 26 days in $\mathrm{X}$. galactinus. Both species have 5 nymphal stadia. The egg production varies a great deal with the individuals, the number of egg per female in L. beneficus being 10-36.5-65 and 24-44.7-63 (min-avg-max) in $X$.galactinus. The eggs of both species are oviposited on or in several material, such as cherry twig, corn, filter paper, paddy straw, vermiculite, etc. The eggs laid by the young adults show high rate of hatching. The fecundity suddenly decreases from 4 week old female, and the vitality of off-spring produced from such an old female is also inferior to that from the younger one.

In the giant straw pile at Saga Paper Board Co., the spring emergence of L. beneficus and X. galactinus begins at the middle of May and the end of April respectively. The population of the bugs reaches a peak at the middle of June, and then it decreases toward July. The second emergence occurs at the end of August. Generally, X. galactinus is predominent in marshy places, while $L$. beneficus is found in arid places. They scarcely occur together in the same habitat. The sex ratio of field collected adults of both species is about 1: 1 throughout the year.

During the summer season, the nocturnal flight of the male adults begins just before the sunset. They, at first, fly over the ground and later fly up to a 
higher range. The peak of appearance at the lower range is at $6.30 \mathrm{pm}$ and the peak at the higher place is $7.00 \mathrm{pm}$. The flying activity of females follows the males about 30 minutes later. They stop to fly at about $9.00 \mathrm{pm}$.

In the field, L. beneficus has 3 generations per year. New adults emerge in May, July, August, September, and X. galactinus has 5 generations, the adults appearing in June, July, August, September and November. But, due to the longer oviposition period, various growing stages are observed throughout the warmer seasons. The emergence of new nymphs stops in October in both species.

The feeding habit of two bugs was investigated with more than 60 species of prey. So far as the author's observation goes, L. beneficus is predacious upon 45 species of 23 families and X. galactinus on 43 species of 22 families. The prey have such common characters as sluggish movement and soft-body, etc. The feeding preference was studied among Ceraphis magnolicolens Takahashi, larvae of wax moth (Galleria mellonella Linné), rice stem borer (Chilo suppressalis (Walker)) and red flour beetle (Tribolium castaneum (Herbst)). The aphid is the most prefered and Tribolium larva comes the next. Difference in preference is seldom observed between the two Lepidopterous larvae. The preference experiment was also conducted with various body-sized Galleria larvae, and it appears that the smallsized larvae are more suitable as food.

The feeding amount of bug per day is very variable depending upon many factors. The feeding amount against the Tribolium larvae was 2.00 and 1.20 in the adult of L. beneficus and X. galactinus respectively. The daily consumption of the mature Chilo larvae by one predator was 0.60 and 0.20 in the separate and gregarious rearing of L. beneficus and 0.32 and 0.24 in X. galactinus. The reduction of food consumption under a gregarious condition is due to the concentrated attack of many bugs on one prey.

In the earlier nymphal stage, the conversion ratio of food is higher than that of the later nymphal stage in both species. The predatory value in the adult stage is lower than that of the nymphal stage. The value is lower in the earlier nymphal stage in both species.

The nutritional reliance on plant substances seems to be restricted and the sucking of plant juice keeps the life of nymphs and adults for a very short period. No oviposition is observed under the deficiency of animal diet. The order of suitability of feeding habit in both species is as follows : carnivorous $>$ cannibalistic $>$ necrophagous $>$ fungivorous $>$ phytophagous.

The fecundity of bugs is greatly influenced by the kind of foods. The bugs reared with the Tribolium larvae show the highest fecundity and the Chilo-fed bugs come the next. The Galleria-fed bugs show the worst result that is characterized by the longest pre-oviposition period and the lowest egg-production. 
For the purpose of studying this phenomenon in detail, the amino acid composition of Tribolium and Galleria larvae was analyzed and compared. As the result of analysis, the content of free amino acids in the former food was $73.50 \mu \mathrm{mol} / \mathrm{g}$ and that of the latter food was 30.63. The contents of essential amino acids were 23.58 and 8.10 respectively. Among the amino acids, the contents of aspartic acid, serine, alanine, valine, isoleucine, methionine, leucine, tyrosine and phenylalanine in the Tribolium larvae exceed 3 times that of the other foods. The amino acid analysis was also conducted with the adults of $L$. beneficus reared with the Tribolium and Galleria larvae. No significant quantitative variation in the composition of amino acid was observed between the bugs reared with different foods. It becomes evident that the Tribolium-fed bug can take more amino acid nitrogen for the reproductive activity than the bug fed with another kind of diets. The contents of ether extract are much more abundant in the Galleria larvae than in the Tribolium larvae, being 0.22 and $0.04 \mathrm{~g} / \mathrm{g}$ respectively. The paper chromatogram of these extracts was markedly different, although no identification was conducted.

For the rearing of bugs with artificial media, four methods were used. Among them, the use of the medium soaked uretank foam is most preferable. The most favourable result was obtained with the medium composed of $2 \mathrm{~g}$ dextrose, $2 \mathrm{~g}$ soluble starch, $2 \mathrm{~g}$ sodium caseinate, $2 \mathrm{~g}$ yeast extract, $1 \mathrm{~g}$ beef extract, $0.05 \mathrm{~g}$ cholesterol, $0.2 \mathrm{~g}$ Wassen's salt per $100 \mathrm{ml}$ water. But the rearing result with this medium is much inferior to that with the animal diets either on the survival or growth rate. The frequent cannibalism was observed when several bugs were reared gregariously with the medium. No egg was produced by the female reared with the medium. The addition of 1.0 or $0.5 \mathrm{mg}$ a-tocopherol to $100 \mathrm{ml}$ medium prolonged the longevity and prevented the cannibalism for a certain extent.

The ovarian development relating to the nutritional condition was studied anatomically with the bugs reared with various foods. The ovarian development was the best in the Tribolium reared bugs, and the mature eggs were recognized on the 5th and 3rd day after the emergence of L.beneficus and $X$. galactinus respectively. The ovarian development of Chilo- and Galleria-fed bugs was inferior to that of the Tribolium-fed individuals and no mature egg was observed during the same period. The number of immature eggs was also abundant in the Tribolium-fed bugs. The adult fed with plant juices showed a slight ovarian development till the 3rd day, but the ovary rather degenerated on the 5th day.

The survival, egg-production and the rate of egg hatching of bugs under the various population densities were investigated. In the petri-dish of 6 $\times 9 \mathrm{~cm}$ in height and diameter, the best result was obtained to rear 10 and 20 adult pairs of L. beneficus and X.galactinus respectively. The nymphal growth and the rate of survival were superior in 40 and 60 individuals 
in the same petri-dish.

In both species, the adult was more tolerable against the coldness than nymphs. When adult was exposed to $-3^{\circ} \mathrm{C}$, the activity stopped within $3 \mathrm{mi}-$ nutes and the exposure of 30 minutes was fatal. Under the temperature of $5{ }^{\circ} \mathrm{C}$ condition, the paralysis occured within 30 minutes, the lethal time at this temperature being 6 and 5 days in L. beneficus and $X$. galactinus respectively. Although the young nymphs did not survive under the temperature condition of $4^{\circ} \mathrm{C}$, the older nymphs reached very slowly to the adults while no oviposition was seen. In the field condition, both species seemed to overwinter in the adult stage under the shelter of warmer places.

The relative toxicities of 10 pesticides against both species were studied with the residual film method. Against the laboratory reared young adults, 0.025 and $0.05 \%$ parathion showed $100 \%$ mortality to L. beneficus and X.galactinus respectively. Sumithion was the next toxic pesticide, the mortality being 86 and $84 \%$ in $0.2 \%$ solution against $L$. beneficus and $X$. galactinus respectively. The other pesticides were scarcely harmful in their conventional concentrations. To the field collected individuals, the tolerance was more inferior to the laboratory reared ones, and parathion, sumithion, dipterex and diazinone gave high mortality. The high sensitivity in the field collected individuals was partly attributed to the age structure of the field population. And this consideration was verified by the linear increase of the sensitivity to sumithion with the process of age in the laboratory reared population. The pesticidal sensitivity relating to the nutritional condition was also discussed. The pesticidal tolerance in the nymphal stage was higher in the last instar, exceeding that of the laboratory reared young adults.

When the 1st stage nymphs of both species were reared in the same cage, the nymphs of $X$. galactinus were always superior in growth and survival. The presence of $X$. galactinus adults gave serious effect on the survival of younger nymphs of $L$. beneficus. The mixed rearing of the adult $L$. beneficus and the nymphs of $X$. galactinus gave little effects on the nymphal growth. The mixed rearing of the adults of both species gave bad effect on the oviposition period and egg-production of $L$. beneficus, but little influence on $X$. galactinus.

A Braconid parasite of rice stem borer, Apanteles chilonis [Munakata], was always influenced by the presence of bugs. The piercing of the borer body by the bugs gave fatal effect on the survival of the wasp which was parasitizing the borer owing to the withering of the host insect. The bug prefered to attack the mature larvae of the wasp just crawled out of the borer body. Therefore the emergence of Apanteles wasps under the presence of bugs was very few.

The mass-production procedure of bugs was designed with the use of vermiculite and cracked corn. For the most efficient method, the bugs were reared with cracked corn medium provided with a piece of moist filter paper 
for an oviposition substratum. The larvae of T.castaneum were the most suitable food, and the method of mass culture of T. castaneum was also discussed. The separation of bugs from the culture media was designed too.

The preying effect of bugs on the rice stem borer is evident when the bugs are in contact with the borer directly. Though the amount of prev consumed by the bugs decreased under the straw condition, the survival rate of the bugs rather increased. The preying activity was higher at $30^{\circ} \mathrm{C}$ than at $25^{\circ} \mathrm{C}$. The illumination has little influence on the preying activity. Dry straw condition stimulated the activity than the moist condition of material. But, to keep the moderate moisture condition in the straw was indispensable to maintain the rate of high survival of the bugs. Nymphs were almost impossible to attack the freely crawling borers, but accessible to the borer when the latter was confined to the straw. When the adults and nymphs were present in the same container, the adult bugs attacked their nymphs instead of the borers. The preying activity of bugs was not significant against the borers in the paddy stubbles. Under such an environment the bugs preyed on some small creatures which were found in the stubbles or crawling or walking on the soil surface.

\section{Acknowledgement}

The author wishes to express his cordial thanks to Prof. K. Yasumatsu under whose direction and encouragement this work was performed. Many interesting ideas in connection with the planning of this work were suggested by him. In addition, the author is much obliged to him for the advice and constructive criticism he so willingly gave and for the careful help in the preparation of this manuscript.

The author has no words in expressing his hearty appreciation to Prof. S. Miyamoto, for many valuable advice and criticism especially in the field of systematics of the family Anthocoridae.

The author would like to express his thanks to Dr. Y. Hirashima and Dr. K. Yano for their constant warm hospitality in every possible way to perform this study. He is also greatly obliged to Dr. G. Funatsu of Biochemical Laboratory, Kyushu University for his help in the analysis of amino acids. For the field observation, the co-operation of Mr. M. Hata of Saga Paper Board Co. is greatly appreciated.

Further, the author extends his sincere thanks to many colleagues of the Entomological Laboratory and the Institute of Biological Control, Kyushu University for their helpful suggestion and valuable discussion during the course of this study. 


\section{Literature cited}

Albrecht, F. O. et al. 1958. Determination de la fertilité par l'effect de groups chezle criquet migrateur. Biol. Bull. 92 : 349-427. (in Watt 1960)

Allee, W. C. 1934. Recent studies in mass physiology. Biol. Rev. 9 (1): 1-48.

Anderson, N. H. 1962a. Bionomics of six species of Anthocoris in England. Trans. R. ent. Soc. Lond. 114 (3): 67-95

Anderson, N. H. 1962b. Growth and fecundity of Anthocoris spp. reared on various prey. Ent. exp. \& appl. 5 (1) : 40-52.

Andrewartha, H. G. and Birch, L. C. 1960. Some recent contributions to the study of the distribution and abundance of insects. Ann. Rev. Ent. 5: 219-42.

Annand, P. N. 1942a. Report of the Chief of the Bureau of Entomology and Plant Quarantine. U.S. D. A. 19 (41): 120 pp.

Annand, P. N. 1942b. Report of the Chief of the Bureau of Entomology and Plant Quarantine. U.S. D. A. $19(41-42): 60 \mathrm{pp}$.

Anonym, 1942. Memoria de la Estación experimental agricola de La Molina correspondiente al an̂o 1941. 6: 276 pp. Lima Minist. Peru. (in Rev. Appl. Ent. 1944, 32 (12): 428).

Anonym. 1953. Proc. Rep. Saga Agri. Exp. Sta. in 1953 pp. 189-91.

Anonym. 1954. Proc. Rep. Saga Agri. Exp. Sta. in 1954 pp. 182-5.

Ascher, K. R.S. and Neri, I. 1961. Lipoid content and resistance in the housefly. Ent. exp. \& appl. 4 (1): 7-19.

Atallah, Y.H. and Newson, L. D. 1966. Ecological and nutritional studies on Coleomegilla maculata DeGeer. I. The development of an artificial diet and a laboratory rearing technique. Jour. Econ. Ent. 59 (5): 1173-9.

Atallah, Y. H. and Killebrew, R. 1967. Ecological and nutritional studies on Coleomegilla maculata DeGeer. IV. Amino acid requirements of the adults determined by the use of $\mathrm{C}^{14}$-labeled acetate. Ann. Ent. Soc. Am. 60 (1): 186-8.

Atkins, E. L., Jr. 1958. The western tussock moth, Hemerocampa vetusta (Bdr.) on citrus in southern California. Jour. Econ. Ent. 51 (6) : 762-5.

Atkins, E. L., Jr. et al. 1957. The “omnivorous leaf roller" Platynota stultana on cotton in California; Nomenclature, life history and bionomics (Tortricidae). Ann. Ent. Soc. Am. 50 (3) : 251-9.

Auclair, J. L。 and Raulston, J. R. 1966. Feeding of Lygus hesperus on a chemically defined diet. Ann. Ent. Soc. Am. 59 (5) : 1016-7.

Ballard, E. 1921. A preliminary note on Triphleps tantilus Mosch., an enemy of the pink worm. Agric. Jour. India 16 (5) :571-3.

Barber, G. W.1936a. The corn earworm in southern Georgia. Bull. Geor. Exp. Sta. No. 192 (18) : 771.

Barber, G. W. 1936b. Orius insidiosus, an important natural enemy of the corn earworm. U. S. D. A. Tech. Bull. No. 504, 24 pp.

Barber, G. W. 1943. Oviposition habits of the earworm moth in relation to infestation in the ears and to control. Jour. Econ. Ent. 34 (4j: 611-8.

Bartholomai, C. W. 1954. Predatism of European corn borer eggs by Arthropods. Jour. Econ. Ent. 47 (2): 295-9.

Bartlett, B. R. 1963. The contact toxicity of some pesticide residues to hymenopterous parasites and coccinellid predators. Jour. Econ. Ent. 56 (5): 694-8.

Bartlett, B. R. 1964. Integration of chemical and biological control. In DeBach(ed.), 
Biological control of inset pests and weeds. Pp. 489-511, Chapman and Halls, London.

Recks, S. D. et al. 1949. Nutrition of the European corn borer, Pyrausta nubilalis (Hbn.). I. Development of a satisfactory purified diet for larval growth. Ann. Ent. Soc. Am. 42 (4) : 483-96.

Beck, S. D. et al. 1958. Feeding and nutrition of the milkweed bug, Oncopeltus fasciatus (Dallas). Ann. Ent. Soc. Am. 51 (3) : 283-8.

Beirne, B. P. 1967. The future of integrated controls. Mushi 39, Suppl. pp. 127-30.

Bell, K. D. and Whitecomb, W. H. 1964. Field studies on egg predators of the bollworm, Heliothis zea (Boddie). Florida Ent. 47 (3): 171-80.

Bess, H. A. 1967. Feasibility and problems of chemical control and biological control of rice stem borers. Mushi 39, Suppl. pp. 45-50.

Blatchley, W. S. 1926. Heteroptera of true bugs of Eastern North America. Pp. 621-46. Nature Publ. Co., Indianapolis.

Bodenheimer, F. 1921. Zur Kenntnis der Chrysanthemum-Wanzen sowie der durch sie hervorgerufenn. Gallbildung. Zeitschr. Pflanzenkr. 31: 3-4.

Bondar, G. 1924. A ferrugem na folha du algodoeiro. Correio-Agricola. 2 (6) :172-4. (in Rev. Appl. Ent. 1924, 12 (9) : 413).

Boyce, J. M. 1946. The influence of fecundity and egg mortality on the population growth of Tribolium confusum Duval. Ecology 27 (4) : 290-302.

Bracken, G. K. 1965. Effects of dietary components on fecundity of the parasitoid Exeristes comstockii. Canad. Ent. 97 (10): 1037-41.

Bracken, G. K. 1966. Role of ten dietary vitamins on fecundity of the parasitoid Exeristes comstockii. Canad. Ent. 98 (9) : 918-22.

Brönnimann, H. 1964. Rearing Anthocorids on an artificial medium. Tech. Bull. Commw. Inst. Biol. Contr. No. 4, pp. 147-50.

Burke, H. R. 1959. Toxicity of several insecticides to two species of beneficial insects on cotton. Jour. Econ. Ent. 52 (4): 616-8.

Busvine, J. R. 1951. Insects and Hygiene. P. 341. Methuen Co., London.

Butler, E. A. 1923. Biology of the British Hemiptera-Heteroptera. Pp. 324-6. Witherby Co., Holborn, W. C.

Butler, C. C. 1954, The method and importance of the recognition by a colony of honey bees of the presence of its queen. Trans. R. ent. Soc. Lond. 103 (1) : 11-29.

Butler, G. D. 1966. Development of several predacious Hemiptera in relation to temperature. Jour. Econ. Ent. 59 (5): 1306-7.

Carayon, J. 1953. Organ de Ribaga et fécondation hemocoelienne chez les Xylocoris du groupe galactinus. Comp. Rend. Acad. Sci. Paris 236: 1099-101.

Carayon, J. et Steffan, J. R. 1959. Observations sur le regime alimentaire des Orius et particulièrement d'Orius pallidicornis (Reuterj. Cah. Nat. Bull. N. P. (n. s.) 15: 53-64.

Carayon, J. 1961. Quelques remarques sur les Hémiptères-Hétéroptères:Leur importance comme insects auxilliaires et les possibilites de leur utilization dans la lute biologique. Entomophaga 6 (2): 133-41.

Chalfant, R. B. and Mitchell, E. R. 1967. Some effects on food and substrate on oviposition of the spotted cucumber beetle. Jour. Econ. Ent. 60 (4) : 1010-2.

Chapman, N. R. 1928. The quantitative analysis of environmental factors. Ecology 9(2): 698-711.

Chapman, R. N. and Whang, W. Y. 1934. An experimental analysis of the cause of population fluctuations. Science, N. Y. 8 (2074) : 297-8. 
Chauvin, R. 1946. Notes sur la physiologie comparée des Orthoptères. V. L'effect de groups et la croissance larvaire des Blattes, des Grillons et du Phaneroptère. Bull. Soc. 2001. Fr. 71 (1) : 39-48.

China, W. E. 1926. A new species of Triphleps preying on the eggs of Heliothis obsoleta H.-S. in Queensland. Bull. Ent. Res. 16 (4j:361-2.

China, W. E. and Miller, N. C. E. 1955. Check list of family and subfamily names in Hemiptera-Heteroptera. Ann. Mag. Nat. Hist. Lond. 12 (8) : 257-67.

China, W. E. and Miller, N. C. E. 1959. Check list and key to the families and subfamilies of the Hemiptera-Heteroptera. Bull. Brit. Mus. Ent. 8 (1) : 1-45.

Chu, Y. I. 1962a. Identification of sugar and amino acids on the haemolymph of lindane treated Papilio. Mem. Coll. Agr. Nation. Taiwan Univ. 6 (4) : 38-41.

Chu, Y. I. 1962b. Quantitative determination of amino acid and sugars on the haemolymph of lindane treated Papilio. Mem. Coll. Agr. Nation. Taiwan Univ. 6 (4): $42-6$.

Chumakova, B. M. 1962. Significance of individual food components for the vital activity of mature predatory and parasitic insects. Vop. Ekol. Kievsk. $8: 133-4$. (in Biol. Abstr, 1962, 45 ( $44 j$ : 502).

Collyers, E. 1967. On the ecology of Anthocoris nemorum (L.). Proc. R. ent. Soc. Lond. Ser. (Aj, 42 (7-9) : 107-18.

Corti, A. 1921. Lyctocoris campestris F. un Memico ignorato del Baco da Seta. Atti. Soc. Ital. Sci. Nat. in Milano 110 (1): 1-10. (in Rev. Appl. Ent. 1921, 9 (8): 404).

Dadd, R. H. 1963. Feeding behavior and nutrition in grasshopper and locust. Adv. Insect Physiol. 1: 47-109.

Davis, C. J. and Krauss, N. L. H. 1963. Recent introduction for biological control in Hawaii VIII. Proc. Hawaii. Ent. Soc. for 1962, 18 (2): 245-9.

Davis, C. J. and Krauss, N. L. H. 1964. Recent introduction for biological control in Hawaii IX. Proc. Hawaii. Ent. Soc. for 1963, 18 (3): 391-7.

Davis, C. J. and 'Krauss, N. L. H. 1965a. Recent introduction for biological control in Hawaii X. Proc. Hawaii. Ent. Soc. for 1964, 19 (1) : 87-90.

Davis, C. J. and Krauss, N. L. H. 1965b. Recent introduction for biological control in Hawaii XI. Proc. Hawaii. Ent. Soc. for 1964, 19 (2): 201-7,

DeBach, P. 1966. The comparative displacement and coexistence principles. Ann. Rev. Ent. 11: 183-212.

DeGroot, A. P. 1953. Protein and amino acid requirements of the honeybee. Physiol. Comparata et Oecol. 3: 197-285.

DeLoach, C. J., Jr. and Miyatake, Y. 1966. Seasonal abundance and degree of parasitism of the Asiatic rice borer in Fukuoka Prefecture, Japan. Mushi 39 (3): 31-46.

Dempster, J. P. 1960. A quantitative study of the predators on the eggs and larvae of the broom beetle, Phytodecter olivacea, using the precipitin test. Jour. Anim. Ecol. $29: 149-67$.

Dempster, J. P. 1963. The natural prey of three species of Anthocoris living on broom. Ent. exp. \& appl. 6 (2): 149-55.

Diakonoff, A. 1940. Remarks on a predatory bug. Ent. Med. Ned.-Ind. 35 (3): 55-6.

Dicke, F. F. and Jarvis, J. L. 1962. The habits and seasonal abundance of Orius insidiosus (Say) on corn. Jour. Kansas Ent. Soc. 35 (3) : 339-44.

Dimond, J. B. et al. 1956. The amino acids required for egg production in Aedes aegypti. Canad. Ent. 88 (1): 107-8.

Doeksen, J. 1944. Een nieuwe beschadiging van maiskolven. Tij. Pl. Ziekt. 50 (4) : 107 to 8 . 
Douglas, J. W. and Scott, J. 1865. The British Hemiptera-Heteroptera. Pp. 495-6. Ray Soc., London.

DuPort, E. M. 1917. The eye-spotted bud moth (Eucosma ocellana Schiff.). Ninth Ann. Rept. Quebec Soc. Protec. Plants from Insect \& Fungus Dis. 1916-7. Pp. 118-37.

Durrant, A. 1955. Effects of time embryo formation on quantitative characters in Drosophila. Nature 175 (4456j : 560-1.

Earle, N. W. et al. 1967. Essential fatty acids in the diets of the boll weevil (Anthonomus grandis Boheman). Jour. Ins. Physiol. 13 (2): 187-200.

Esaki, T. and Hashimoto, S. 1935. Report on the leafhoppers injurious to the rice plant and their natural enemies. No. 7, p. 23. Ent. Lab. Dept. Agr. Kyushu Imp. Univ. Fukuoka, Japan.

Evans, D. E. 1962. The food requirements of Phonoctonus nigrofasciatus Stål (Hemiptera, Reduviidae j. Ent. exp. \& appl. 5 (1) : 33-9.

Ewing, K. and Ivy, E. E. 1943. Some factors influencing ball worm population and damage. Jour. Econ. Ent. 36 (4) : 602-6.

Fast, P. G. 1964. Insect lipids: A review. Mem. Ent. Soc. Can. No. 37, 50 pp.

Feir, D. 1963. Effects of rearing alone and in groups on the growth of the milkweed bug, Oncopeltus fasciatus (Lygaeidae). Ann. Ent. Soc. Am. 56 (3j : 406-7.

Fewks, D. W. 1960. The food requirements by weight of some British Nabidae. Ent. exp. \& appl. 3 (3) : 231-7.

Fieber, F. X. 1837. Weit. Beitr. 1: 107. (in Reuter 1884).

Fieber, F. X. 1860. Die europäischen Hemiptera, Halbflügler, nach der analytischen Methode bearbeitet. 1860. P. 61, Wien. (in Butler 1923).

Fletcher, R. K. and Thomas, F. L. 1943. Natural control of eggs and first instar larvae of Heliothis armigera. Jour. Econ. Ent. 36 (4j : 557-60.

Flint, W. P. 1918. Insect enemies of the chinch bug. Jour. Econ. Ent. 11 (5) : 415-9.

Foster, S. W. and Jones, P. R. 1915. The life history and habits of the pear thrips in California. U. S. D. A. Bull. No. 173, 52 pp.

Fraenkel,G. and Blewett, M. 1946. Linoleic acid, vitamin E and other fat-soluble substances in the nutrition of certain insects (Ephestia kuehniella, E. elutella, E. cautella and Plodia interpunctella). Jour. Exp. Biol. 22 (3-4): 172-90.

Fronk, W. D. 1947. The southern pine beetle, its life history. Tech. Bull. Va. Agr. Exp. Sta. No. 108. (in Rev. Appl. Ent. 1950, 38 (10): 415).

Funasaki, G. Y. 1966. Studies on the life cycle and propagation technique of Montandoniola moraguesi (Puton). Proc. Hawaii. Ent. Soc. 19 (2): 209-11.

Garman, H. and Jewett, H. H. 1914. The life-history and habits of the corn-ear worm (Chlorida obsoleta). Ky. Agr. Exp. Sta. Bull. No. 187, pp. 511-91. (in Dicke1962).

Garman, P. and Townsend J. F. 1938. The European red mite and its control. Bull. Conn. Agr. Exp. Sta. No. 416, 6 pp.

Gilliatt, F. 1937. Natural control of the grey-banded leaf roller Eulia mariana, in Nova Scotia orchards. Canad. Ent. 69 (7) : 145-6.

Gilmour, I). 1961. The biochemistry of insects. Academic Press, New York.

Golberg, L. and DeMeillon, B. 1948. The nutrition of the larvae of Aedes aegypti L.IV. Protein and amino acid requirements. Biochem. Jour. 43 (3) : 379-87.

Good, N. E. 1933. Biology of the flour beetles, Tribolium confusum Duval and T. ferrugineum Fabr. Jour. Agr. Res. 46 (4): 327-31.

Good, N. E. 1936. The flour beetles of the genus Tribolium. Tech. Bull. U.S. D.A. No. 498, $57 \mathrm{pp}$.

Gordon, H. T. 1961. Nutritional factors in insect resistance to chemicals. Ann. Rev. 
Ent. 6. 27-54.

Gratiwick, M. 1965. Laboratory studies of the relative toxicities of orchard insecticides to predatory insects. 52nd Rep. E. Malling Res. Sta. 1964, pp. 171-6.

Green, C. D. 1964. The effect of crowding upon the fecundity of Folsomia candida (William) var. distincta (Bagnall). Ent. exp. \& appl. 7 (1) : 62-70.

Greenberg, J. 1951. Some nutritional requirements of adult mosquitoes (Aedes aegypti) for oviposition. Jour. Nutr. 43 (1): 27-35.

Gyotoku, N. 1960. [On the natural enemies of Chilo suppressalis Walker]. Proc. Assoc. P1. Prot. Kyushu 6: 1-3.

IIagen, K. S. 1950, Fecundity of Chrysopa californica as affected by synthetic foods. Jour. Econ. Ent. 43 (1) : 101-4.

Hagen, K. S. 1958. Honeydew as an adult fruit fly diet affecting reproduction. Proc. 10th Intern. Congr. Ent. 3: 25-30.

Hagen, K. S. and Tassen, R. L. 1965. A method of providing artificial diets to Chrysopa larvae. Jour. Econ. Ent. 58 (5): 999-1000.

Hagen, K. S. and Tassen R. L. 1966. A method of coating droplets of artificial diet with paraffin for feeding Chrysopa larvae. (in Ecology of aphidophagous insects, pp. 89-90. Academic Pub. House. Prague).

Hahn, C. W. 1835. Die Wanzenartigen Insecten 3: 19-20.

Hall, D. W. 1951. Observations on the distribution, habits and life history of the bug, Piezostethus galactinus. Ent. mon. Mag. 86 (14th Ser. No. 121) : 45-52.

Hambleton, E. J. 1944. Heliothis virescens as a pest of cotton, with notes on host plants in Peru. Jour. Econ. Ent. 37 (5): 660-6.

Hanison, F. P. 1960. Corn earworm oviposition and the effects of DDT on the egg predator complex in corn silk. Jour. Econ. Ent. 53 (6): 1088-94.

Harein, P. K. and Soderstrom, E. L. 1966. Coleoptera infesting stored products. (in Smith (ed.), Insect colonization and mass production, pp. 247-53. Acad. Press, N. Y. and London).

Harlow, P. M. 1956. A study of ovarial development and its relation to adult nutrition in the blowfly, Protophormia terrae-novae. Jour. Exp. Biol. 33 (4) : 777-97.

Hassan, A. A. G. et al. 1960. Analysis of the relative abundance of some beneficial insects on cotton plants treated by certain insecticides. Bull. Soc. Ent. Egypte 44 : 179- 84.

Herbst, J. F. W. 1797. Natursystem aller bekannten in- und auslandischen Insecten, als eine Forsetzung der vom buff onschen Naturgeschichte. Der Käfer, pts. 7, p. 282.

Herne, D. H. C. and Putman, W. L. 1966,. Toxicity of some pesticides to predacious arthropods in Ontario peach orchard. Canad. Ent. 98 (9): 936-42.

Herring, J. L, 1967. Heteroptera, Anthocoridae. Insect of Micronesia 7 (8) : 391-414.

Hilchey, J. D. 1953. Studies on the quantitative requirement of Blattella germanica (L.) for amino acids under aseptic condition. Contri. Boyce Thompson Inst. 17 (3) : 203-19.

Hill, R. E. 1945. Effect of DDT and other insecticides on several species of potato insects. Res. Bull. Nebr. Agr. Exp. Sta. No. 138. (in Rev. Appl. Ent. 1946, 34 (7) :223).

Hill, A. R. 1957. The biology of Anthocoris nemorum (L.) in Scotland. Trans. R. ent. Soc. Lond. 113 (3) : 41-54.

Hill, A. R. 1965. The bionomics and ecology of Anthocoris confusus Reuter in Scotland. I. The adult and egg production. Trans. Soc. Brit. Ent. 16 (9): 245-56.

Hinton, H. E. 1948, A synopsis of the genus Tribolium Macleay with some remarks on the evolution of its species groups. Bull. Ent. Res. 39 (1) : 13-56.

Hinton, T. et al. 1951. Amino acid and growth factors in a chemically defined medium 
for Drosophila. Physiol. 2001. 24 (4) : 335-53.

Hirano, C. 1963. Effect of dietary unsaturated fatty acids on the growth of larvae of Chilo suppressalis. Japanese Jour. Appl. Ent. 2001. 7 (1) : 59-62.

Hiura, I. 1957. Description of a new species of Japanese Anthocoridae, and its biology. Sci. Bull. Fac. Agr. Kyushu Univ. 16 (1): 31-9.

Hiura, I. 1966. Contribution to the knowledge of Anthocoridae from Japan and its adjacent territories (3). Bull. Osaka Mus. Nat. Hist. 19: 29-37,

Ho, F. K. 1967. Identification of Tribolium larvae by their setal characteristics. Ann. Ent. Soc. Am. 60 (4) : 729-32.

House, H. L. 1954. Nutritional studies with Pseudosarcophaga affinis (Fall.), a Dipterous parasite of the spruce bud worm, Choristineura fumiferana (Clem.). III. Effects of nineteen amino acids on growth. Canad. Jour. 2001. 32 (4) :351-9.

House, H. L. 1958. Nutritional requirements of insects associated with animal parasitism. Exp. Parasitol. 7: 555-609.

House, H. L. 1962. Insects nutrition. Ann. Rev. Biochem. 31: 653-72.

House, H. L. 1965. Insect Nutrition. (in The physiology of Insects, 2: 769-814. Acad. Press., N. Y. and London).

House, H. L. 1966. Effects of vitamins E and A on growth and development, and the necessity of vitamin E for reproduction in the parasitoid Agris affinis (Fallen). Jour. Ins. Physiol. 12 (4) : 409-17.

Howe, R. W. 1952. Entomological problems of food storage in northern Nigeria. Bull. Ent. Res. 43 (1): 111-44.

Howe, R. W. 1956. The effect of temperature and humidity on the rate of development and mortality of Tribolium castaneum. Ann. Appl. Biol. 44 (2): 356-68.

Howe, R. W. 1960. The effects of temperature and humidity on the rate of development and the mortality of Tribolium confusum. Ann. Appl. Biol. 48 (2): 363-76.

lglinsky, W. and Rainwater, C. F. 1950. O rius insidiosus, as enemy of a spider mite on cotton. Jour. Econ. Ent. 43 (4): 567-8.

Ishihara, T. 1941. Hemiptera-Heteroptera as the natural enemies for controlling the pests. Botany and Zoology. 9 (9): 223-9.

Ishii, S. and Hirano, C. 1955. Qualitative studies on the essential amino acids for the growth of the larvae of the rice stem borer, under aseptic conditions. Bull. Nation. Inst. Agr. Sci. Japan C5: 35-48.

Ito, Y. et al. 1960. Natural mortality of the common cabbage butterfly Pieris rapae crucivora Boisduval with consideration on the factors affecting it. Japanese Jour. Appl. Ent. 2001. 4 (1): 1-10.

Johansen, C. and Brekey, E. P. 1949. Insecticides tested against the willamette mites on red raps-berries. Jour. Econ. Ent. 42 (3): 562-3.

Johnson, C. G. 1960. The relation of weight of food ingested to increase in body weight during growth in the bed bug, Cimex lecturarius. Ent. exp.\& appl. 3 (3): $238-40$.

Kamel, M. 1951. The biological control of the cotton leaf-worm (Prodenialitura F.) in Egypt. Bull. Soc. Fouad $1^{\text {er }}$ Ent. 35e: 221-70.

Kasting, R. and McGinnis, A. J. 1959. Nutrition of the pale western cutworm, Agrotis orthogonia Morr. Canad. Jour. 2001. 37 (3): 259-66.

Kelly, E. 0. A. 1915. A new wheat thrips. Jour. Agr. Res. 4 (3): 219-24.

Kelton, L. A. 1967. Synopsis of the genus Lyctocoris in North America and description of a new species from Quebec. Canad. Ent. 99 (8j : 807-14.

Khalifa, A. and Badawy, A. 1955a. The effect of nutrition on the biology of Tribolium 
confusum Duv., Tribolium castaneum Hbst. and Latheticus oryzae Waterh. Bull. Soc. Ent. Egypte 39: 337-50.

Khalifa, A. and Badawy, A. 1955b. Biological studies on Tribolium confusum Duv., Tribolium castaneum Hbst. and Latheticus oryzae Waterh. Bull. Soc.Ent.Egypte 39 : 351-73.

Kirkaldy, G. W. 1906. List of the genera of the Pagiopodous Hemiptera-Heteroptera, with their type species, from 1758 to 1904 (and also of the aquatic and semi-aquatic Trochalopoda). Trans. Am. Ent. Soc. 32: 117-56.

Lewis, D. J. 1958. Hemiptera of medical interest in the Sudan Republic. Proc. R. ent. Soc. Lond. 33 (1-3) : 43-7.

Lingren, P. D. and Ridgway, R. L. 1967. Toxicity of five insecticides to several insect predators. Jour. Econ. Ent. 60 (6): 1939-41.

Loher, W. 1961. The chemical acceleration of the maturation process and its hormonal control in the male of the desert locust. Proc. R. Soc. (B) 153: 380-97.

Lord, F. T. 1949. The influence of sprays programs on the fauna of apple orchards in Nova Scotia, III. Mites and their predators. Canad. Ent. 81 (8-9) :202-14.

Luginbill, P. 19.28. The fall armyworm. Tech. Bull. U. S. D. A. No. 34, 91 pp.

Lüscher, M. 1956. Hemmende und fördernde Faktoren bei der Entstehung von Ersatzgeschlechtstieren bei der Termite, Kalotermes flavicollis Fabr. Rev. Suisse Zool. 63: 261-7.

Maclagen, D. S. 1932. An ecological study of the lucerne flea (Smynthurus viridisj. Bull. Ent. Res. 23 (1-2) : 101-45.

Malenotti, E. 1926. Impressioni sull'andamento delladecorsa campagna bacologica. L'Italia Agricola (in Rev. Appl. Ent. 1926. 14 (1): 36).

Malloch, J. R. 1916. Triphleps insidiosus sucking blood. Ent. News 27 (5) : 200.

Marcovitch S. and Stanley, W. W. 1941. The tomato fruit worm in Tennessee. Bull, Tenn. Agr. Exp. Sta. No. 174. 18pp.

Marshall, G. E. 1930. Some observation on O rius insidiosus (Say). Jour. Kansas Ent. Soc. 3 (2) : 29-32.

Martini, E. 1946. Lehrbuch der medizinischen Entomologie. Pp. 145-6. Jena.

Massee, A. H. and Steer, W. 1926. Tar distillate washes and red spiders. Jour. Minist. Agric. 36 : 253-7.

Matheson, R. 1950. Medical entomology. 2nd Ed. P. 188. Comstock Publ. Co., Ithaca, New York.

Matsumura, S. 1920. [Applied Entomology.] p. 427. Keiseisha Co., Tokyo.

McFarlane, J. E. 1962. A comparison of the growth of the house cricket (Orthoptera : Gryllidae) reared singly and in groups. Canad. Jour. 2001. 40 (4): 559-60.

McFarlane, J. E. and Henneberry, G. 0. 1965. Inhibition of the growth of an insect by fatty acids. Jour. Ins. Physiol. 11 (9): 1247-52.

McGregor, E. A. 1913. The red spider on cotton. U. S. Bureau of Ent. Circ. No. 172, 22 PP.

McGregor, W. S. 1942. O rius insidiosus, a predator on cotton insects in Western Texas. Jour. Econ. Ent. 35 (3): 454-5.

McLachlan, R. 1879. P. E. Soc. pp. 93-4. (in 2001. Rec. 1879. 16: 237).

McLachlan, R. 1880. P. E. Soc. pp. 29-30. (in 2001. Rec. 1880. 17: 230).

McMullen, R. D. and Jong, C. 1967. The influence of three insecticides on predation of the pear Psylla, Psylla pyricola.Canad. Ent. 99 (12) : 1292-7.

Meikle, J. E.S. and McFarlane, J. E. 1965. The role of lipid in the nutrition of the house cricket, Acheta domesticus L. Canad. Jour. 2001. 43 (1): 87-98. 
Mertz, D. B. 1961. Identification of Tribolium species by pupal characteristics. Ecology 42 (4) : 811-8.

Metcalf, R. L. and Newell, I. M. 1962. Investigation of the biochromes of mites. Ann. Ent. Soc. Am. 55 (3) : 350-3.

Michal, K. 1931. Die Beziehung der Populationsdichte zum Lebensoptimum aus der Zahlenverhältnis der Geschlechter bei Mehwurm und Stubenfliege. Biologia Gen. 7 (3) : 631-46.

Michelbacher, A. E. et al. 1952. Mites on melons in northern California. Jour. Econ. Ent. 45 (3) : 365-70.

Misra, C. S. 1924. Observations on some Rhynchota from Northern India. Rep. Proc. 5th Ent. Meeting, Pusa(1923), p. 300.

Mitchell, R. G. and Wright, K. H. 1967. Foreign predator introductions for control of the balsam woolly aphis in the Pacific Northwest. Jour. Econ. Ent. 60 (I.): 140-7.

Miyamoto, S. 1957. List of ovariole numbers in Japanese Heteroptera. Sieboldia 2 (1) : 69-82.

Miyamoto, S. 1961. Comparative morphology of alimentary organs of Heteroptera, with the phylogenic consideration. Sieboldia 2 (4) : 198-259.

Miyamoto, S. and Lee, C. E. 1966. Heteroptera of Quelpart Island. Sieboldia 3 (4): 313-411.

Mizukami, T. and Oho, N. 1955. Euspudaeus sp. as a predator of Chilo suppressalis. Plant Prot. 9 (1): 10 figs.

Morkrzecki, Z. 1923. Sprawozdanie z. dzialalnosci Zakladów ochrony Lasu i Entomologji w Skierniewicach. Ecole. Sup. Agr. à Varsovie L(1922-23): 32. (in Rev. Appl. Ent. 1924, 12 (3): 105).

Morley, C. 1905. The Hemiptera of Suffolk. (in Butler 1923).

Myers, J. G. 1929. Facultative blood-sucking in phytophagous Hemiptera. Parasitol. 21 (4) : 472-80.

Nickel, J. L. 1964. Biological control of rice stem borer: a feasibility study. Tech. Bull. Intern. Rice Res. Inst. 2 : i-iii, 1-111.

Norris, M. J. 1950. Reproduction in the African migratory locust (Locusta migratoria migratorioides R. \& F.) in relation to density and phase. Anti-locust Bull. No. 6, 47 PP.

Norris, M. J. 1952. Reproduction in the desert locust (Schistocerca gregaria Forsk.) in relation to density and phase. Anti-locust Bull. No. 13, 49 pp.

Norris, M. J. 1954. Sexual maturation in the desert locust (Schistocerca gregaria Forsk.) with special reference to the effects of grouping. Anti-locust Bull. No. 18, 44 pp.

Norris, M. J. 1959. Reproduction in the red locust (Nomadacris septemfasciana Serville) in the laboratory. Anti-locust Bull. No. 38, 46 pp.

Nutting, W. L. and Gerhardt, P. D. 1964. A study of the Khapra beetle, Trogoderma granarium, in commercial grain storage in Southern Arizona. Jour. Econ. Ent. 57 (3) : 305-14.

Ogilvie, L. 1927. Report of the plant pathologist for the year 1926. Rep. Dept. Agr. Bermuda 1926, pp. 35-41. (in Rev. Appl. Ent. 1928, I6 (1): 17).

Oho, N. 1955a. On the Euspudaeus sp., as a parasite of the rice stem borer (Chilo suppressalis Walker). Bull. Saga Agr. Exp. Sta. 1 : 45-6.

Oho, N. 1955b. On the Euspudaeus sp. as a predator of the rice stem borer. Proc. Assoc. Pl. Prot. Kyushu 34: 222-4.

Oho, N. 1955c. On the Euspudaeus sp. as a parasite of the rice stem borer, I. The food habits and life history. Proc. Assoc. Pl. Prot. Kyushu 16: 59-61. 
Oku, T. and Kobayashi, T. 1966, Influence of the predation of Orius sp. on the aphis population in a soy-bean field. Japanese Jour. Appl. Ent. Zool. 10 (2) : 89-94.

Orr, C. W. H. 1964. The influence of nutritional and hormonal factors on egg development in the blow fly. Jour. Ins. Physiol. 10 (1) : 53-64.

Ouchi, Y. 1967. [Rearing of Nephotettix cincticeps by artificial diets] . Rep. Symp. 1967 Meeting, Japanese Soc. Appl. Ent. Zool. p. 19.

Pant, N. C. and Uberoi, N. K. 1958. On the carbohydrate utilization by the larvae of Trogoderma granarium. Experientia 14 (2) : 71-2.

Park, T. 1932. Studies in population physiology. The relation of numbers to initial population growth in the flour beetle Tribolium confusum Duval. Ecology 13 (2): $172-81$.

Park, T. et al. 1965. Cannibalistic predation in populations of flour beetle. Physiol. Zool. 38 (3) : 289-321.

Parson, E. S. and Ullyett, G. C. 1934. Investigations on the control of the American red boll worms of cotton in South Africa. Bull. Ent. Res. 25 (3): 349-81.

Pearl, R. and Parker, S. L. 1922. On the influences of density of population upon the rate of reproduction in Drosophila. Proc. Nat. Acad. Sci. U.S. A. 8: 212-9.

Pearl, R. et al. 1927. Experimental studies on the duration of life. XI. Density of population and life duration in Drosophila. Amer. Nat. 61 (675) : 289-318.

Pearl, R. 1932. The influence of density of population upon egg production in Drosophila melanogaster. Jour. Exp. Zool. 63 (1) : 57-84.

Pettit, L. C. 1940. The effect of isolation on growth in the cockroach Blattella germanica. Ent. News 51 (10): 293.

Phillips, W. J. and King, K. M. 1923. The corn ear-worm: its raveges on field corn and suggestion for control. U.S. D. A. Farmer's Bull. No. 1310, 17 pp.

Phillips, W. J. and Barber, G. W. 1933. Egg laying habits and fate of eggs of the corn ear-worm moth and factors affecting them. Tech. Bull. Va. Agr. Exp. Sta. No. 47, 34 PP.

Pickett, C. and Friend, W. G. 1965. The nutritionally essential amino acids of Rhodnius prolixus (Stål) determined with glucose-U-14C. Jour. Ins. Physiol. 11 (12) : 1617-23.

Piez, K. A. and Morris, L. 1960. A modified procedure for the automatic analysis of amino acids. Anal. Biochem. 1 (1) : 187-201.

Poppius, B. 1909. Beiträge zur Kenntnis der Anthocoriden. Act. Soc. Sci. Fenn. 37 (9) : $1-43$.

Prohaska, K. 1923. Beiträge zur Kenntnis der Hemiptera Kärtens. Carinthia 2: 32-101 (in Rev. Appl. Ent. 1925, 13 (7): 311).

Putman,W.L. 1964. Occurrence and food of some Coccinellids in Ontario peach orchards. Canad. Ent. 96 (9) : 1149-55.

Putman, W. L. 1965. Paper chromatography to detect predation on mites. Canad.Ent. 97 (4): $435-41$.

Qureshi, A. H. 1966?. A simple technique for rearing larvae of Tribolium castaneum in the laboratory. Rep. Niger. Stored Prod. Res. Inst. 1965: 105-6. (in Rev. Appl. Ent. 1967, 55 (7): 393).

Rainwater, C.F. 1951. Seasonal decline in the effectiveness of certain insecticides against boll weevil. Jour. Econ. Ent. 44 (6): 971-4.

Rao, B.R.S. and Chawla, S. S. 1964. A catalogue of Hymenopterous parasites of rice stem borer. Indian Jour. Ent. 26 (3) : 332-44.

Rasso, S.C. and Fraenkel, G. 1954. The food requirements of the adult female blow-fly, 
Phormia regina, in relation to ovarian development. Ann. Ent. Soc. Am. 47 (4) : 636-45.

Reiser, R. et al. 1953. Variations in lipid content of the boll weevil and seasonal variation in its resistance to insecticides. Jour. Econ. Ent. 46 (2): 337-40.

Reuter, 0. M. 1871a. Skandinaviens och Finlands Acanthiider beskrifine. Öfvers. K. Vetensk-Akad. Förh. 28 : 403-29.

Reuter, O. M. 1871b. Acanthiidae americanae, descriptae. Öfvers. K. Vetensk-Akad. Förh. 28: 557-67.

Reuter, 0. M. 1884. Monographia Anthocoridarum orbis terrestris. Act Soc. Sci. Fenni. $14: 555-758$.

Reuter, 0. M. 1908. Charakteristik und Entwickelungeschichte der Hemiptera Fauna der palaearktischen Coniferen. (in Butler $1923 \mathrm{j}$.

Richards, G. and Kolderie, M. Q. 1957. Variation in weight, developmental rate and hatchability of Oncopeltus eggs as a function of the mother's age. Ent. News 68 (3): $57-64$.

Richardson, C. H, et. al. 1931. The determination of the blood volume of insect larvae. Ann. Ent. Soc. Am. 24 (3) : 503-7.

Richardson, H. H. and Nelson, R. H. 1933. Field control of the gladiolus thrips (Taeniothrips gladioli). Jour. Econ. Ent. 26 (3): 546-54.

Riley, W. A. and Johannsen, 0. A. 1938. Medical Entomology. P. 146. McGraw-Hill Book Co., New York.

Rock, G. C. et al. 1965. Studies of the fatty acid requirements of Argyrotaenia velutinana (Walker). Jour. Ins. Physiol. 11 (1): 91-101.

Rock, G. C. 1967. Aseptic rearing of the codling moth on synthetic diets: Ascorbic acid and fatty acid requirements. Jour. Econ. Ent. 60 (4): 1002-5.

Sands, J. H. 1951. The biology of some British Anthocoridae. (M. S c. thesis, London Univ.), (in Anderson 1962a).

Sang, J. H. 1956. The quantitative nutritional requirements of Drosophlia melanogaster. Jour. Exp. Biol. 33 (1): 45-72.

Sang, J. H. and King, R. C. 1961. Nutritional requirements of axenically-cultured Drosophila melanogaster. Jour. Exp. Biol. 38 (4) : 793-809.

Saunders, J. P. and Kruger, H. 1957. A rapid method for counting larvae of the confused flour beetle. Jour. Econ. Ent. 50 (5): 693.

Scheel, C. A. et al. 1957. Nutrition of plant sucking Hemiptera. Science 125 (3245) : 444-5.

Scheel, C. A. et al. 1958. Feeding and nutrition of certain Hemiptera. Proc. 10th Intern. Congr. Entomol., Montreal 1956, 2: 303-8.

Shiraki, T. 1958. Sanitary insects. Pp. 186-7. Hokuryukan, Tokyo.

Simón, F. J. E. 1954. Algunas experiencies eu el control de las plagas del algodonero: maís intercalado e insecticidas sistémicos. Int. Ectac. Exp. Agr. La Molinar No. 90 (22): 7. (in Rev. Appl. Ent. 1956, 44(3) : 97).

Sing, K.R.P. and Brown, A. W. A. 1957. Nutritional requirement of Aedes aegypti L. Jour. Ins. Physiol. 1 (3): 199-220.

Sinha, R. N. 1961. Insects and mites associated with hot spots in farm stored grains. Canad. Ent. $93(8$,$) : 609-21.$

Sinha, B. P. and Mookhewee, P. B. 1967. Studies on the effect of airtightness on the development of Tribolium castaneum in wheat and wheat flour. Indian Jour. Ent. 29 (1 j : 79-83.

Slama, K. 1962. The juvenile hormone-like effects of fatty acids, fatty alcohols and 
some other components in insect metamorphosis. ActaSoc. Ent. Cechoslov, 59 (4) : $323-40$.

Smirnoff, W. A. 1958. An artificial diet for rearing Coccinellid beetles. Canad. Ent. 90 (9) : 563-5.

Smith, B. C. 1960. A technique for rearing Coccinellid beetles on dry foods and influence of various pollens on the development of Coleomegilla maculata.Canad. Jour. Zool. 38 (6): 1047-9.

Smith, B. C. 1965. Effects of food on the longevity, fecundity and development of adult Coccinellids. Canad. Ent. 97 (9) : 910-9.

Sonleither, F. J. 1961. Factors affecting egg cannibalism and fecundity in populations of adult Tribolium castaneum. Physiol. Zool. 34 (3) : 233-55.

Southwood, T. R. E. and Leston, D. 1959. Land \& water bug of British Island. Pp. 1856. New York, Fredk. Warne \& Co. Ltd., London.

Stanley, J. 1962. The Tribolio-trap. Canad. Jour. Zool. 40 (8): 1313.

Stern, V. M. et al. 1959. The integration of chemical and biological control of the spotted alfalfa aphid. I. The integrated control concept. Hilgardia 29 (2):81101.

Strong, L. C. 1954. Parental age and characteristics of the offspring. Ann. N. Y. Acad. Sci. 57; 451-614.

Stultz, H. T. 1955. The influence of spray programs on the fauna of apple orchards in Nova Scotia. VIII. Natural enemies of the eye-spotted bud moth, Spilonotaocellana (D.\& S.). Canad. Ent. 87 (Zj : 79-85.

Stys, P. and Daniel, M. 1957. Lyctocoris campestris (F.), as a human facultative ectoparasite. Acta Soc. Ent. Cechoslov. 54 (1): 88-97.

Sundby, R. A. 1967. Influence of food on the fecundity of Chrysopa carnea Stephens (Neuroptera, Chrysopidae). Entomophaga 12 (5) : 475-9.

Sweetman, H. L. 1958. Successful biological Control against animals. Proc. 10th Intern. Congr. Ent. Montreal, 1956, 4: 449-56.

Tanaka, M. and Maeda, Y. 1965. Rearing of some predacious Coccinellid beetles by the artificial diets. Bull. Hort. Res. Sta. Japan, Ser. D. 3: 17-35.

Tateishi, I. 1962. [On the parasitization and sex ratio of Apanteles flavipes Cameron]. Proc. Assoc. P1. Prot. Kyushu 8: 26-9.

Tawfik, M. F. S. and Nagui, A. 1965. The biology of Montandoniola moraguesi Puton, a predator of Gynaikothrips ficorum Marchal in Egypt. Bull. Soc. Ent. Egypte 49 : 181-200.

Theobald, F. V. 1895. Notes on the needle nosed hop bugs. J. S.-E. Agr. Coll. Wye 2 : 11-6. (in Hill 1957).

Thompson, W. R. 1951. The specificity of host relations in predacious insects. Canad. Ent. 83 (10) : 262-9.

Torre-Bueno, J. R. 1931. Biting bugs. Bull. Brookl. Ent, Soc. 26 (4) : 176.

Trägardh, I. 1914. Skogsentomogiska bidrag. 1-5. Ent. Tidsk, 3-4: 188-209.

Trager, W. 1953. Nutrition. In Roeder (ed.), Insect Physiology, pp. 350-86. Wiley, New York.

Tucker E. S. 1911. Random notes on entomological field work. Canad. Ent, 43 (1) : 2232.

Turner, E. C. 1967. Effect of diet on longevity and fecundity of laboratory-reared face flies. Jour. Econ. Ent. 60 (3): 857-60.

Tuttle, D. M. et al. 1961. The cotton leaf perforator and its control in Arizona. Jour. Econ. Ent. 54 (1) :67-70. 
Underhill, G. W. 1926. Studies on the potato tuber moth during the winter of 1925-6. Bull. Va. Agr. Exp. Sta. No. 251, 21 pp.

van den Bosch, R. and Stern, V. M. 1962. The integration of chemical and biological control of arthropod pests. Ann. Rev. Ent. 7: 367-86.

van Duzee, E. P. 1916. Check list of the Hemiptera (excluding the Aphididae, Aleurodidae and Coccidae) of America North of Mexico. Pp. 288-97. New York.

van Poetran, N. 1930. Verslag over de Werkzaamheden van den Plantenziekten kundigen Dienst in het Jaar 1926. Versl. Plantenziektenk. Dienst in het Jaar 1929. No, 62, 3.42 pp. (in Rev. Appl. Ent. 1931, 19 (5) : 242 j.

Vanderzant, E. S. 1957. Growth and reproduction of the pink bollworm on an amino acid medium. Jour. Econ. Ent. 50 (2) : 219-21.

Vanderzant, E. S. 1958. The amino acid requirements of the pink bollworm. Jour. Econ. Ent. 51 (3) : 309-11.

Vanderzant, E. S. 1967. Rearing Lygus bugs on artificial diets. Jour. Econ. Ent. 60 (3) : 813-6.

Veitch, R. 1927. The corn ear-worm on tomatoes. Queensland Agr. Jour. 28 (6) : 5858.

Viswanathan, C. V. and Meera Bai, B. 1962. Application of reversed phase circular paper chromatography to the analysis of higher fatty acid. Jour. Chromatog. 7 (4): 507-15.

Wagner, E. 1955. Lyctocoris nidicola n. sp., eine neue Anthocoriden Art aus Finnland (Hem., Het.). Notul. Ent. 35 (2) : 60-Z.

Watson, T. K. and Widde, W. H. A. 1963. Laboratory and field observations on two predators of the pear psylla in British Columbia. Canad. Ent. 95 (4) : 435-8.

Watt, K. E. F. 1960. The effect of population density on fecundity of insects. Canad. Ent. 92 (9): 674-95.

Weber, P. W. 1953. Recent liberation of beneficial insects in Hawaii. II. Proc. Hawaii. Ent. Soc. for 1952,15 (1) : 127-30.

Wene, G. P. and Sheets, L. W. 1962. Relationship of predatory and injurious insects in cotton field in the Salt River area of Arizona. Jour. Econ. Ent. 55 (3): 395-8.

Wharton, D. R. A. et al. 1967. Population density, survival, growth and development of the American cockroach. Jour. Ins. Physiol. 13 (5): 699-716.

Wigglesworth, V. B. 1960. Nutrition and reproduction in insect. Proc. Nutrition Soc.19: $18-23$.

Wilde, W. II. A. 1962. The pear psylla in British Columbia. Canad. Dept. Agr. Publ. (in Watson and Widde 1963).

Willcocks, F. C. 1916. The pink bollworm, the insect and related pests of Egypte. Sultanic Agr. Soc. 1(1): 339 pp.

Wille, J. E.1951. Biological control of certain cotton insects and the application of new insecticides in Peru. Jour. Econ. Ent. 44 (1) :13-8.

Willis, E. R. et al. 1958. Observation on reproduction and development in cockroaches. Ann. Ent. Soc. Am. 51 (1) : 53-69.

Wilson, II. F. and Moznette, G. F. 1915. The bud moth Tometocera ocellana Schiff. Second biennial crop pest and horticultural report 1913-1914. Oregon Agr. Exp. Sta, pp. 102-8.

Winburn, 'I'. F. and Painter, R. H. 1932. Insect enemies of the corn-worm. Jour. Kansas Ent. Soc. 5 (1): 1-28.

Woodward, T. E. 1951. A case of persistent attacks on a human by Lyctocoris campestris (F.). Ent. mon. Mag. 86 (14th Ser. No. 121): 44. 
Yasumatsu, K. 1964. The possible control of rice stem borers by the use of natural enemies. In: The maior insect pests of the rice plant. Pp. 431-442. The Johns Hopkins Press, Baltimore.

Yasumatsu, K. and Watanabe, C. 1964. A tentative catalogue of insect natural enemies of injurious insect in Japan. 1: 6-7. Ent. Lab, Kyushu Univ., Japan.

Yasumatsu, K. 1967. Distribution and bionomics of natural enemies of rice stem borers. Mushi 39, Suppl. : 33-44.

Yasumatsu, K. and Torii, T. 1968. Impact of parasites, predators and diseases on rice pests. Ann. Rev. Ent. 13 : 295-324.

Young, R. G. 1964. Lipids of the larvae of the greater wax moth, Galleria mellonella. Ann. Ent. Soc. Am. 57 (3) : 321-4.

Young, R. G. 1967. Fatty acids of some Arthropods. Mem. Cornell Univ. Agr. Exp. Sta. No. 401,14 pp.

Yun, Y. M. and Ruppel, R. F. 1964. Toxicity of insecticides to a coccinellid predator of the cereal leaf beetle. Jour. Econ. Ent. 57 (6): 853-7.

Zaher, M. A. and Long, D. B. 1959. Some effects of larval population density on the biology of Pieris brassicae L. and Plusia gamma L. Proc. R. ent. Soc. Lond. (A) 34 (7-9) : 97-109. 